\title{
Statistische bijlage : werkgelegenheid en scholing 2003
}

Citation for published version (APA):

Researchcentrum voor Onderwijs en Arbeidsmarkt, ROA. (2004). Statistische bijlage : werkgelegenheid en scholing 2003. Researchcentrum voor Onderwijs en Arbeidsmarkt, Faculteit der Economische Wetenschappen. ROA Reports No. 1B https://doi.org/10.26481/umarep.200401B

Document status and date:

Published: 01/01/2004

DOI:

10.26481/umarep.200401B

Document Version:

Publisher's PDF, also known as Version of record

\section{Please check the document version of this publication:}

- A submitted manuscript is the version of the article upon submission and before peer-review. There can be important differences between the submitted version and the official published version of record.

People interested in the research are advised to contact the author for the final version of the publication, or visit the DOI to the publisher's website.

- The final author version and the galley proof are versions of the publication after peer review.

- The final published version features the final layout of the paper including the volume, issue and page numbers.

Link to publication

\footnotetext{
General rights rights.

- You may freely distribute the URL identifying the publication in the public portal. please follow below link for the End User Agreement:

www.umlib.nl/taverne-license

Take down policy

If you believe that this document breaches copyright please contact us at:

repository@maastrichtuniversity.nl

providing details and we will investigate your claim.
}

Copyright and moral rights for the publications made accessible in the public portal are retained by the authors and/or other copyright owners and it is a condition of accessing publications that users recognise and abide by the legal requirements associated with these

- Users may download and print one copy of any publication from the public portal for the purpose of private study or research.

- You may not further distribute the material or use it for any profit-making activity or commercial gain

If the publication is distributed under the terms of Article $25 \mathrm{fa}$ of the Dutch Copyright Act, indicated by the "Taverne" license above, 


\section{Statistische Bijlage Werkgelegenheid en scholing 2003}

ROA-R-2004/1B

Researchcentrum voor Onderwijs en Arbeidsmarkt

Faculteit der Economische Wetenschappen en Bedrijfskunde Universiteit Maastricht

Maastricht, juni 2004 
Niets uit deze uitgave mag worden verveelvoudigd en/of openbaar gemaakt door middel van druk, fotokopie, microfilm, of op welke wijze ook, zonder voorafgaande schriftelijke toestemming van de directeur van het Researchcentrum voor Onderwijs en Arbeidsmarkt. In geval van overname van het datamateriaal moet telkens duidelijk als bron worden vermeld: "Researchcentrum voor Onderwijs en Arbeidsmarkt" of "ROA". Van publicaties waarin gebruik wordt gemaakt van gegevens uit deze Statistische bijlage ontvangen wij gaarne een exemplaar.

Hoewel de grootst mogelijke zorg is besteed aan de inhoud van dit rapport, kan het ROA in generlei opzicht verantwoordelijkheid op zich nemen voor eventuele onvolledigheden of onjuistheden.

ISBN 90-5321-389-9

Sec04.012.doc 


\section{Inhoud}

Bladzijde

Voorwoord

i

\section{Landbouw en visserij}

Tabel 1.1 Kernindicatoren 1

Figuur 1.1 Sectoraal risicoprofiel 2

Tabel 1.2 Percentage werkenden dat regelmatig wordt geconfronteerd met lawaai

Tabel 1.3 Percentage werkenden dat regelmatig werkt met trillende apparaten,

Tabel 1.4 Percentage werkenden dat regelmatig kracht moet zetten tijdens het werk,

Tabel 1.5 Percentage werkenden dat regelmatig onder hoge tijdsdruk werkt,

Tabel $1.6 \quad$ Percentage werkenden dat regelmatig beeldschermwerk verricht, gemiddelde 2001-2002 4

Tabel 1.7 Pecentage werkenden dat deelneemt aan scholingstrajecten korter dan 6 maanden, gemiddelde 2001-2002 5

Tabel 1.8 Percentage werkenden dat deelneemt aan scholingstrajecten van 6 maanden

Tabel 1.9 Doelgroepen voor het scholingsbeleid en risicofactoren $\quad 5$

\section{Voeding}

Tabel 2.1 Kernindicatoren 9

$\begin{array}{lll}\text { Figuur 2.1 Sectoraal risicoprofiel } & 10\end{array}$

$\begin{array}{lll}\text { Tabel 2.2 Percentage werkenden dat regelmatig wordt geconfronteerd met lawaai } & \\ & \text { tijdens het werk, gemiddelde 2001-2002 }\end{array}$

Tabel 2.3 Percentage werkenden dat regelmatig werkt met trillende apparaten,

Tabel 2.4 Percentage werkenden dat regelmatig kracht moet zetten tijdens het werk,

Tabel 2.5 Percentage werkenden dat regelmatig onder hoge tijdsdruk werkt,

gemiddelde 2001-2002

2001-2002 14

Tabel 2.7 Pecentage werkenden dat deelneemt aan scholingstrajecten korter dan 6 maanden, gemiddelde 2001-2002 15

Tabel 2.8 Percentage werkenden dat deelneemt aan scholingstrajecten van 6 maanden

Tabel 2.9 Doelgroepen voor het scholingsbeleid en risicofactoren $\quad 16$

\section{Chemie}

Tabel 3.1 Kernindicatoren

$\begin{array}{lll}\text { Figuur 3.1 Sectoraal risicoprofiel } & 20\end{array}$

Tabel 3.2 Percentage werkenden dat regelmatig wordt geconfronteerd met lawaai

Tabel 3.3 Percentage werkenden dat regelmatig werkt met trillende apparaten, 
gemiddelde 2001-2002

Tabel 3.4 Percentage werkenden dat regelmatig kracht moet zetten tijdens het werk, gemiddelde 2001-2002

Tabel 3.5 Percentage werkenden dat regelmatig onder hoge tijdsdruk werkt, gemiddelde 2001-2002

Tabel 3.6 Percentage werkenden dat regelmatig beeldschermwerk verricht, gemiddelde 2001-2002

Tabel 3.7 Pecentage werkenden dat deelneemt aan scholingstrajecten korter dan 6 maanden, gemiddelde 2001-2002

Tabel 3.8 Percentage werkenden dat deelneemt aan scholingstrajecten van 6 maanden of langer, gemiddelde 2001-2002

\section{Metalektro}

Tabel 4.1 Kernindicatoren 27

$\begin{array}{lll}\text { Figuur } 4.1 & \text { Sectoraal risicoprofiel } & 28\end{array}$

Tabel 4.2 Percentage werkenden dat regelmatig wordt geconfronteerd met lawaai tijdens het werk, gemiddelde 2001-2002

Tabel 4.3 Percentage werkenden dat regelmatig werkt met trillende apparaten, gemiddelde 2001-2002

Tabel 4.4 Percentage werkenden dat regelmatig kracht moet zetten tijdens het werk, gemiddelde 2001-2002

Tabel 4.5 Percentage werkenden dat regelmatig onder hoge tijdsdruk werkt, gemiddelde 2001-2002

Tabel 4.6 Percentage werkenden dat regelmatig beeldschermwerk verricht, gemiddelde 2001-2002

Tabel 4.7 Pecentage werkenden dat deelneemt aan scholingstrajecten korter dan 6 maanden, gemiddelde 2001-2002

Tabel 4.8 Percentage werkenden dat deelneemt aan scholingstrajecten van 6 maanden of langer, gemiddelde 2001-2002

Tabel 4.9 Doelgroepen voor het scholingsbeleid en risicofactoren

\section{Overige industrie}

Tabel 5.1

Figuur 5.1

Tabel 5.2

Kernindicatoren

Sectoraal risicoprofiel

Percentage werkenden dat regelmatig wordt geconfronteerd met lawaai tijdens het werk, gemiddelde 2001-2002

Tabel 5.3 Percentage werkenden dat regelmatig werkt met trillende apparaten, gemiddelde 2001-2002

Tabel 5.4 Percentage werkenden dat regelmatig kracht moet zetten tijdens het werk, gemiddelde 2001-2002

Tabel 5.5 Percentage werkenden dat regelmatig onder hoge tijdsdruk werkt, gemiddelde 2001-2002

Tabel 5.6

Percentage werkenden dat regelmatig beeldschermwerk verricht, gemiddelde 2001-2002

Tabel 5.7

Pecentage werkenden dat deelneemt aan scholingstrajecten korter dan 6 maanden, gemiddelde 2001-2002

Tabel 5.8 Percentage werkenden dat deelneemt aan scholingstrajecten van 6 maanden of langer, gemiddelde 2001-2002

Tabel 5.9 Doelgroepen voor het scholingsbeleid en risicofactoren 


\section{Energie}

$\begin{array}{lll}\text { Tabel } 6.1 & \text { Kernindicatoren } & 47\end{array}$

$\begin{array}{lll}\text { Figuur } 6.1 & \text { Sectoraal risicoprofiel } & 48\end{array}$

$\begin{array}{lll}\text { Tabel } 6.2 & \text { Percentage werkenden dat regelmatig wordt geconfronteerd met lawaai } \\ & \text { tijdens het werk, gemiddelde 2001-2002 }\end{array}$

Tabel 6.3 Percentage werkenden dat regelmatig werkt met trillende apparaten,

Tabel 6.4 Percentage werkenden dat regelmatig kracht moet zetten tijdens het werk, gemiddelde 2001-2002 49

Tabel 6.5 Percentage werkenden dat regelmatig onder hoge tijdsdruk werkt,

Tabel 6.6 Percentage werkenden dat regelmatig beeldschermwerk verricht, gemiddelde

Tabel 6.7 Pecentage werkenden dat deelneemt aan scholingstrajecten korter dan 6 maanden, gemiddelde 2001-2002

Tabel 6.8 Percentage werkenden dat deelneemt aan scholingstrajecten van 6 maanden of langer, gemiddelde 2001-2002

8

48

(1)

(1)

50

\section{Bouw}

Tabel 7.1

Kernindicatoren

Tabel 7.2 Percentage werkenden dat regelmatig wordt geconfronteerd met lawaai tijdens het werk, gemiddelde 2001-2002

Tabel 7.3 Percentage werkenden dat regelmatig werkt met trillende apparaten, gemiddelde 2001-2002

Tabel 7.4 Percentage werkenden dat regelmatig kracht moet zetten tijdens het werk, gemiddelde 2001-2002

Tabel 7.5 Percentage werkenden dat regelmatig onder hoge tijdsdruk werkt, gemiddelde 2001-2002

Tabel 7.6 Percentage werkenden dat regelmatig beeldschermwerk verricht, gemiddelde 2001-2002

Tabel 7.7 Pecentage werkenden dat deelneemt aan scholingstrajecten korter dan 6 maanden, gemiddelde 2001-2002

Tabel 7.8 Percentage werkenden dat deelneemt aan scholingstrajecten van 6 maanden of langer, gemiddelde 2001-2002

Tabel 7.9 Doelgroepen voor het scholingsbeleid en risicofactoren

\section{Handel}

Tabel 8.1

Figuur 8.1

Kernindicatoren

Tabel 8.2

Sectoraal risicoprofiel

Percentage werkenden dat regelmatig wordt geconfronteerd met lawaai

tijdens het werk, gemiddelde 2001-2002

Tabel 8.3 Percentage werkenden dat regelmatig werkt met trillende apparaten, gemiddelde 2001-2002

Tabel 8.4

Percentage werkenden gemiddelde 2001-2002

Tabel 8.5

Percentage werkenden gemiddelde 2001-2002

Tabel 8.6

Percentage werkenden dat regelmatig beeldschermwerk verricht, gemiddelde 2001-2002

Tabel 8.7

Pecentage werkenden dat deelneemt aan scholingstrajecten korter dan 6 maanden, gemiddelde 2001-2002 
Tabel 8.8 Percentage werkenden dat deelneemt aan scholingstrajecten van 6 maanden of langer, gemiddelde 2001-2002

Tabel 8.9 Doelgroepen voor het scholingsbeleid en risicofactoren

\section{Transport en communicatie}

Tabel $9.1 \quad$ Kernindicatoren $\quad 81$

Figuur 9.1 Sectoraal risicoprofiel

Tabel 9.2 Percentage werkenden dat regelmatig wordt geconfronteerd met lawaai tijdens het werk, gemiddelde 2001-2002

Tabel 9.3 Percentage werkenden dat regelmatig werkt met trillende apparaten, gemiddelde 2001-2002

Tabel 9.4 Percentage werkenden dat regelmatig kracht moet zetten tijdens het werk, gemiddelde 2001-2002

Tabel 9.5 Percentage werkenden dat regelmatig onder hoge tijdsdruk werkt, gemiddelde 2001-2002

Percentage werkenden dat regelmatig beeldschermwerk verricht, gemiddelde 2001-2002

Tabel 9.6

Tabel 9.7 Pecentage werkenden dat deelneemt aan scholingstrajecten korter dan 6 maanden, gemiddelde 2001-2002

Tabel 9.8 Percentage werkenden dat deelneemt aan scholingstrajecten van 6 maanden of langer, gemiddelde 2001-2002

Tabel 9.9 Doelgroepen voor het scholingsbeleid en risicofactoren

\section{Bank en verzekering}

Tabel $10.1 \quad$ Kernindicatoren $\quad 91$

$\begin{array}{lll}\text { Figuur } 10.1 & \text { Sectoraal risicoprofiel } & 92\end{array}$

Tabel 10.2 Percentage werkenden dat regelmatig wordt geconfronteerd met lawaai tijdens het werk, gemiddelde 2001-2002

Tabel 10.3 Percentage werkenden dat regelmatig werkt met trillende apparaten, gemiddelde 2001-2002

Tabel 10.4 Percentage werkenden dat regelmatig kracht moet zetten tijdens het werk, gemiddelde 2001-2002

Tabel 10.5 Percentage werkenden dat regelmatig onder hoge tijdsdruk werkt, gemiddelde 2001-2002

Tabel 10.6 Percentage werkenden dat regelmatig beeldschermwerk verricht, gemiddelde 2001-2002

Tabel 10.7 Pecentage werkenden dat deelneemt aan scholingstrajecten korter dan 6 maanden, gemiddelde 2001-2002

Tabel 10.8 Percentage werkenden dat deelneemt aan scholingstrajecten van 6 maanden of langer, gemiddelde 2001-2002

\section{Horeca en zakelijke dienstverlening}

Tabel $11.1 \quad$ Kernindicatoren $\quad 99$

$\begin{array}{llr}\text { Figuur 11.1 Sectoraal risicoprofiel } & 100\end{array}$

$\begin{array}{ll}\text { Tabel } 11.2 & \text { Percentage werkenden dat regelmatig wordt geconfronteerd met lawaai } \\ \text { tijdens het werk, gemiddelde 2001-2002 } & 100\end{array}$

Tabel 11.3 Percentage werkenden dat regelmatig werkt met trillende apparaten, gemiddelde 2001-2002

Tabel 11.4 Percentage werkenden dat regelmatig kracht moet zetten tijdens het werk, gemiddelde 2001-2002

Tabel 11.5 Percentage werkenden dat regelmatig onder hoge tijdsdruk werkt, gemiddelde 2001-2002 
Tabel 11.6 Percentage werkenden dat regelmatig beeldschermwerk verricht, gemiddelde 2001-2002

Tabel 11.7 Pecentage werkenden dat deelneemt aan scholingstrajecten korter dan 6 maanden, gemiddelde 2001-2002

Tabel 11.8 Percentage werkenden dat deelneemt aan scholingstrajecten van 6 maanden of langer, gemiddelde 2001-2002

Tabel 11.9 Doelgroepen voor het scholingsbeleid en risicofactoren

\section{Kwartaire diensten}

Tabel $12.1 \quad$ Kernindicatoren

Figuur 12.1 Sectoraal risicoprofiel

Tabel 12.2 Percentage werkenden dat regelmatig wordt geconfronteerd met lawaai tijdens het werk, gemiddelde 2001-2002

Tabel 12.3 Percentage werkenden dat regelmatig werkt met trillende apparaten, gemiddelde 2001-2002

Tabel 12.4 Percentage werkenden dat regelmatig kracht moet zetten tijdens het werk, gemiddelde 2001-2002

Tabel 12.5 Percentage werkenden dat regelmatig onder hoge tijdsdruk werkt, gemiddelde 2001-2002

Tabel 12.6 Percentage werkenden dat regelmatig beeldschermwerk verricht, gemiddelde 2001-2002

Tabel 12.7 Pecentage werkenden dat deelneemt aan scholingstrajecten korter dan 6 maanden, gemiddelde 2001-2002

Tabel 12.8 Percentage werkenden dat deelneemt aan scholingstrajecten van 6 maanden of langer, gemiddelde 2001-2002

Tabel 12.9 Doelgroepen voor het scholingsbeleid en risicofactoren

\section{Overheid en onderwijs}

Tabel 13.1 Kernindicatoren 133

Figuur 13.1 Sectoraal risicoprofiel 134

Tabel 13.2 Percentage werkenden dat regelmatig wordt geconfronteerd met lawaai tijdens het werk, gemiddelde 2001-2002

Tabel 13.3 Percentage werkenden dat regelmatig werkt met trillende apparaten,

Tabel 13.4 Pemiddelde 2001-2002 gemiddelde 2001-2002

Tabel 13.5 Percentage werkenden dat regelmatig onder hoge tijdsdruk werkt, gemiddelde 2001-2002

Tabel 13.6 Percentage werkenden dat regelmatig beeldschermwerk verricht, gemiddelde 2001-2002

Tabel 13.7 Pecentage werkenden dat deelneemt aan scholingstrajecten korter dan 6 maanden, gemiddelde 2001-2002

Tabel 13.8 Percentage werkenden dat deelneemt aan scholingstrajecten van 6 maanden of langer, gemiddelde 2001-2002

\section{Totaal alle sectoren}

Tabel 14.1 Kernindicatoren

Tabel 14.2 Percentage werkenden dat regelmatig wordt geconfronteerd met lawaai tijdens het werk, gemiddelde 2001-2002

Tabel 14.3 Percentage werkenden dat regelmatig werkt met trillende apparaten, gemiddelde 2001-2002

Tabel 14.4 Percentage werkenden dat regelmatig kracht moet zetten tijdens het werk, 
gemiddelde 2001-2002

Tabel 14.5 Percentage werkenden dat regelmatig onder hoge tijdsdruk werkt, gemiddelde 2001-2002

Tabel 14.6 Percentage werkenden dat regelmatig beeldschermwerk verricht, gemiddelde 2001-2002

Tabel 14.7 Pecentage werkenden dat deelneemt aan scholingstrajecten korter dan 6 maanden, gemiddelde 2001-2002

Tabel 14.8 Percentage werkenden dat deelneemt aan scholingstrajecten van 6 maanden of langer, gemiddelde 2001-2002 


\section{Voorwoord}

Werkgelegenheid en scholing 2003 en deze bijbehorende Statistische Bijlage is de vijfde versie van het overzichtsrapport in het kader van het Werkgelegenheid en Scholing Observatorium (WSO) dat het Researchcentrum voor Onderwijs en Arbeidsmarkt (ROA) in opdracht van het Ministerie van Sociale Zaken en Werkgelegenheid heeft opgesteld.

Het observatorium-karakter van dit rapport wordt weerspiegeld door het grote aantal indicatoren dat de revue passeert. Deze kengetallen hebben steeds als doel opvallende factoren of ontwikkelingen te signaleren. Deze Statistische Bijlage beoogt op dit punt wederom te fungeren als een naslagwerk, waarin op systematische wijze een totaaloverzicht wordt gegeven van de in het hoofdrapport besproken indicatoren.

Uitgangspunt van zowel het hoofdrapport als deze Statistische Bijlage is dat telkens informatie wordt gegeven over de verschillende groepen werkenden in een bepaald beroep of de werkenden met een bepaalde opleidingsachtergrond binnen een bepaalde bedrijfssector. In deze Statistische Bijlage wordt de informatie gepresenteerd naar bedrijfssector. Per bedrijfssector wordt eerst ingegaan op een aantal kernindicatoren die betrekking hebben op de sector in haar geheel. Vervolgens wordt door middel van het risicoprofiel voor de betreffende bedrijfssector in kaart gebracht in hoeverre bepaalde risicofactoren binnen de desbetreffende sector zich voordoen en in hoeverre er scholing wordt aangeboden om kwalificatieveroudering te voorkomen of te beperken. Daarna wordt voor de verschillende beroeps- en opleidingssectoren binnen de desbetreffende bedrijfssector zo gedetailleerd mogelijk aangegeven in hoeverre de diverse risicofactoren voor deze specifieke groepen werkenden een rol spelen. Ten slotte wordt aangegeven welke groepen werkenden binnen een sector tot de doelgroepen voor het scholingsbeleid gericht op behoud van werk behoren.

De gepresenteerde indicatoren worden telkens ook kwalitatief getypeerd, uiteenlopend van 'erg laag' tot 'erg hoog'. De typeringen die daarbij worden gebruikt zijn gebaseerd op de gemiddelde score voor de totale werkzame bevolking. Dit om de vergelijkbaarheid tussen de werkenden in de verschillende sectoren mogelijk te maken. De "trends" die voor een aantal indicatoren worden vermeld hebben telkens betrekking op de periode 2000-2002. Wanneer niet kan worden voldaan aan de ondergrens voor publicatie of wanneer het gegeven onbekend is, wordt dit in de tabellen aangegeven met een -

De projectleiding van het WSO is in handen van prof. dr. A. de Grip. Drs. J.B. van Loo en drs. J.M.A.F. Sanders speelden een centrale rol bij de uitvoering van het onderzoek en de totstandkoming van de rapportage. Daarnaast is aan deze Statistische Bijlage meegewerkt door S. Dijksman. Onze dank gaat uit naar de leden van de begeleidingscommissie bij het Ministerie van Sociale Zaken en Werkgelegenheid: drs. L. van der Vliet, drs. L. Bastiaansen en drs. V. Monfils. 

1. Landbouw en visserij 

Tabel 1.1

Kernindicatoren

\section{Arbeidsomstandigheden}

Belastende arbeidsomstandigheden

$\%$ werknemers dat regelmatig geconfronteerd wordt met:

$\begin{array}{rrl}2000 & 2001 / 2002 & \text { typering } \\ \% & \% & \\ 9 & 14 & \text { hoog } \\ 22 & 21 & \text { hoog } \\ 47 & 43 & \text { hoog } \\ 18 & 16 & \text { erg laag } \\ 6 & 11 & \text { laag }\end{array}$

Lawaai

Trilling

Kracht zetten

Tijdsdruk

Beeldschermwerk

Technologische en organisatorische ontwikkelingen

Organisatorische ontwikkelingen

bedrijven

\section{$\%$}

Kleine productverandering, 2000-2002

Ingrijpende productverandering, 2000-2002

41

Veranderingen in positie, 2000-2002

Interne reorganisaties, 2000-2002

Technologische vernieuwingen

$\begin{array}{rr}\begin{array}{r}\text { werkenden } \\ \%\end{array} & \text { bedrijven } \\ \% \\ 23 & - \\ 15 & 21 \\ - & 79\end{array}$

Vernieuwingen in het productieproces, 1999-2001

Automatisering, 2002

\section{Verschuivingen in de werkgelegenheid}

\section{Scholingsdeelname}

$\begin{array}{rrr}2000 & 2001 / & \text { typering } \\ & 2002 & \\ \% & \% & \% \\ 3 & 2 & \text { laag } \\ 13 & 11 & \text { gemiddeld }\end{array}$

Bron: ROA/CBS/OSA 


\section{Risicoprofiel}

Figuur 1.1

Sectoraal risicoprofiel

\section{Landbouw en visserij}

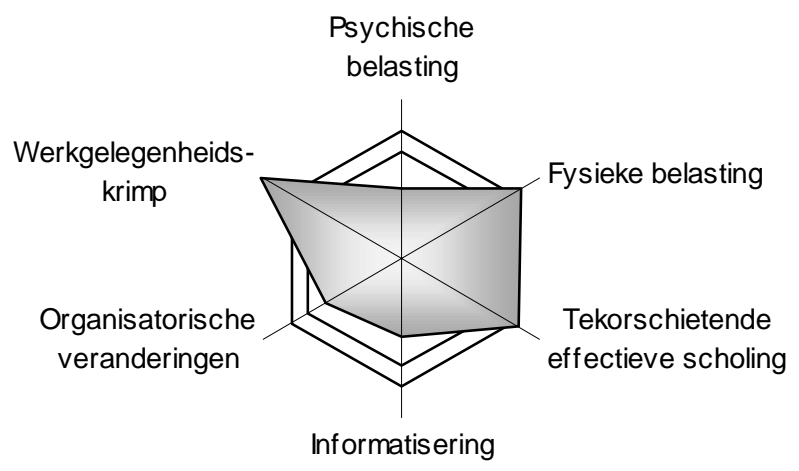

Tabel 1.2

Percentage werkenden dat regelmatig wordt geconfronteerd met lawaai tijdens het werk, gemiddelde 20012002

$\% \quad$ typering trend $2000-2002$

Opleidingen

MBO natuur en techniek

14 hoog constant

\section{Beroepen}

Agrarische beroepen

Agrarische arbeiders

Technische, ambachts- en industrieberoepen

10 gemiddeld

gemiddeld

erg hoog

Specifieke groepen werkenden

Vrouwen

Jongeren

Ouderen

Allochtonen

34 erg hoog

Totaal

14 hoog

10 gemiddeld sterk dalend

- hoog sterk stijgend

14 hoog

Bron: ROA/CBS 
Tabel 1.3

Percentage werkenden dat regelmatig werkt met trillende apparaten, gemiddelde 2001-2002

\begin{tabular}{|c|c|c|c|}
\hline & $\%$ & typering & trend $2000-2002$ \\
\hline \multicolumn{4}{|l|}{ Opleidingen } \\
\hline VMBO natuur en techniek & 29 & hoog & - \\
\hline MBO natuur en techniek & 38 & erg hoog & dalend \\
\hline MBO milieu en groene ruimte & 69 & erg hoog & constant \\
\hline \multicolumn{4}{|l|}{ Beroepen } \\
\hline Agrarische beroepen & 20 & hoog & dalend \\
\hline Agrarische arbeiders & 19 & hoog & dalend \\
\hline \multicolumn{4}{|c|}{ Technische, ambachts- en industrieberoepen } \\
\hline \multicolumn{4}{|l|}{ Specifieke groepen werkenden } \\
\hline $\begin{array}{l}\text { Specine ke groepen werkende } \\
\text { Vrouwen }\end{array}$ & 1 & laag & - \\
\hline Jongeren & 20 & hoog & sterk dalend \\
\hline Ouderen & - & hoog & sterk stijgend \\
\hline Allochtonen & - & erg laag & - \\
\hline Totaal & 21 & hoog & dalend \\
\hline
\end{tabular}

Bron: ROA/CBS

Tabel 1.4

Percentage werkenden dat regelmatig kracht moet zetten tijdens het werk, gemiddelde 2001-2002

\begin{tabular}{|c|c|c|c|}
\hline & $\%$ & typering & trend $2000-2002$ \\
\hline \multicolumn{4}{|l|}{ Opleidingen } \\
\hline Basisonderwijs & 34 & hoog & - \\
\hline VMBO natuur en techniek & 37 & hoog & sterk dalend \\
\hline MBO natuur en techniek & 64 & erg hoog & constant \\
\hline MBO landbouw en veeteelt & 51 & erg hoog & dalend \\
\hline MBO milieu en groene ruimte & 83 & erg hoog & constant \\
\hline \multicolumn{4}{|l|}{ Beroepen } \\
\hline Agrarische beroepen & 45 & hoog & constant \\
\hline Agrarische arbeiders & 48 & erg hoog & constant \\
\hline Technische, ambachts- en industrieberoepen & 47 & erg hoog & sterk stijgend \\
\hline \multicolumn{4}{|l|}{ Specifieke groepen werkenden } \\
\hline Vrouwen & 28 & gemiddeld & sterk stijgend \\
\hline Jongeren & 48 & erg hoog & constant \\
\hline Ouderen & 30 & gemiddeld & - \\
\hline Allochtonen & - & hoog & sterk stijgend \\
\hline Totaal & 43 & hoog & constant \\
\hline
\end{tabular}

Bron: ROA/CBS 


\section{Landbouw en visserij}

Tabel 1.5

Percentage werkenden dat regelmatig onder hoge tijdsdruk werkt, gemiddelde 2001-2002

\begin{tabular}{lccc}
\hline & $\%$ & typering & trend 2000-2002 \\
\hline $\begin{array}{l}\text { Opleidingen } \\
\text { MBO natuur en techniek }\end{array}$ & 20 & laag & stijgend \\
$\begin{array}{l}\text { Beroepen } \\
\text { Agrarische beroepen }\end{array}$ & 14 & erg laag & - \\
$\begin{array}{l}\text { Agrarische arbeiders } \\
\text { Specifieke groepen werkenden }\end{array}$ & 11 & erg laag & - \\
$\begin{array}{l}\text { Vrouwen } \\
\text { Jongeren }\end{array}$ & 13 & erg laag & sterk stijgend \\
$\begin{array}{l}\text { Ouderen } \\
\text { Allochtonen }\end{array}$ & 14 & $\begin{array}{l}\text { erg laag } \\
\text { erg laag }\end{array}$ & sterk dalend \\
Totaal & - & laag & - \\
\hline
\end{tabular}

Bron: ROA/CBS

Tabel 1.6

Percentage werkenden dat regelmatig beeldschermwerk verricht, gemiddelde 2001-2002

\begin{tabular}{|c|c|c|c|}
\hline & $\%$ & typering & trend $2000-2002$ \\
\hline \multicolumn{4}{|l|}{ Opleidingen } \\
\hline MBO natuur en techniek & 11 & laag & sterk stijgend \\
\hline \multicolumn{4}{|l|}{ Beroepen } \\
\hline Agrarische beroepen & 5 & erg laag & sterk stijgend \\
\hline Agrarische arbeiders & 2 & erg laag & sterk stijgend \\
\hline Economisch-administratieve beroepen & 66 & gemiddeld & constant \\
\hline \multicolumn{4}{|l|}{ Specifieke groepen werkenden } \\
\hline Vrouwen & 8 & laag & - \\
\hline Jongeren & 7 & laag & - \\
\hline Ouderen & - & erg laag & sterk stijgend \\
\hline Allochtonen & - & laag & sterk stijgend \\
\hline Totaal & 11 & laag & sterk stijgend \\
\hline
\end{tabular}

Bron: ROA/CBS 
Tabel 1.7

Percentage werkenden dat deelneemt aan scholingstrajecten korter dan 6 maanden, gemiddelde 2001-2002

\begin{tabular}{|c|c|c|c|}
\hline & $\%$ & typering & typering 2000-2002 \\
\hline \multicolumn{4}{|l|}{ Opleidingen } \\
\hline MBO natuur en techniek & 2 & laag & sterk dalend \\
\hline \multicolumn{4}{|l|}{ Beroepen } \\
\hline Agrarische beroepen & 1 & erg laag & sterk dalend \\
\hline Agrarische arbeiders & 1 & erg laag & sterk dalend \\
\hline \multicolumn{4}{|c|}{ Specifieke groepen werkenden } \\
\hline Vrouwen & 1 & erg laag & sterk stijgend \\
\hline Jongeren & 2 & laag & - \\
\hline Ouderen & & - & - \\
\hline Allochtonen & & - & - \\
\hline Totaal & 15 & laag & sterk dalend \\
\hline
\end{tabular}

Bron: ROA/CBS

Tabel 1.8

Percentage werkenden dat deelneemt aan scholingstrajecten van 6 maanden of langer, gemiddelde 20012002

$\% \quad$ typering typering 2000-2002

Opleidingen

MBO natuur en techniek

4 erg laag

Beroepen

Agrarische beroepen

Agrarische arbeiders

13 gemiddeld stijgend

Specifieke groepen werkenden

Vrouwen

Jongeren

14 gemiddeld constant

Ouderen

Allochtonen

$\begin{array}{rll}4 & - & - \\ 16 & \text { hoog } & - \\ - & \text { erg laag } & \text { sterk stijgend } \\ - & \text { laag } & \text { sterk stijgend }\end{array}$

Totaal

11 gemiddeld -

Bron: ROA/CBS

Tabel 1.9

Doelgroepen voor het scholingsbeleid en risicofactoren

$\begin{array}{ll}\text { Doelgroepen } & \text { risicofactor(en) }\end{array}$

Agrarische bedrijfshoofden

Landbouwmachinebestuurders en vissers krimpende werkgelegenheid krimpende werkgelegenheid 

2. Voeding 

Tabel 2.1

Kernindicatoren

\section{Arbeidsomstandigheden}

Belastende arbeidsomstandigheden

$\%$ werknemers dat regelmatig geconfronteerd wordt met:

$\begin{array}{rrl}\begin{array}{r}2000 \\ \%\end{array} & 2001 / 2002 & \text { typering } \\ \% & & \\ 28 & 29 & \text { erg hoog } \\ 10 & 11 & \text { gemiddeld } \\ 24 & 32 & \text { hoog } \\ 28 & 30 & \text { gemiddeld } \\ 38 & 34 & \text { gemiddeld }\end{array}$

Lawaai

Trilling

Kracht zetten

Tijdsdruk

Beeldschermwerk

gemiddeld

Technologische en organisatorische ontwikkelingen

Organisatorische ontwikkelingen

bedrijven

Kleine productverandering, 2000-2002

Ingrijpende productverandering, 2000-2002

11

Veranderingen in positie, 2000-2002

19

Interne reorganisaties, 2000-2002

Technologische vernieuwingen

werkenden bedrijven

$\begin{array}{rr}\% & \% \\ 49 & - \\ 26 & 40 \\ - & 81\end{array}$

Beeldschermwerk, gemiddelde 2001/2002

Vernieuwingen in het productieproces, 1999-2001

Automatisering, 2002

Verschuivingen in de werkgelegenheid

jaarlijks \%

Verwachte werkgelegenheidsontwikkeling, 2003-2008

$-0,2$

Scholingsdeelname

Deelname aan opleidingstrajecten korter dan 6 maanden (momentopname)

Bron: ROA/CBS/OSA 


\section{Risicoprofiel}

Figuur 2.1

Sectoraal risicoprofiel

\section{Voeding}

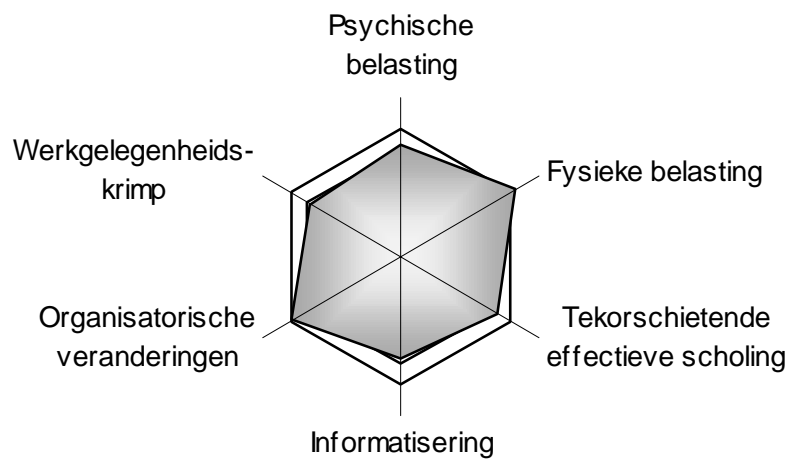

Tabel 2.2

Percentage werkenden dat regelmatig wordt geconfronteerd met lawaai tijdens het werk, gemiddelde 20012002

\begin{tabular}{|c|c|c|c|}
\hline & $\%$ & typering & trend $2000-2002$ \\
\hline \multicolumn{4}{|l|}{ Opleidingen } \\
\hline Basisonderwijs & 43 & erg hoog & constant \\
\hline VMBO natuur en techniek & 42 & erg hoog & sterk dalend \\
\hline MBO natuur en techniek & 36 & erg hoog & constant \\
\hline MBO elektrotechniek & 63 & erg hoog & - \\
\hline MBO economie & 15 & hoog & constant \\
\hline \multicolumn{4}{|l|}{ Beroepen } \\
\hline Technische, ambachts- en industrieberoepen & 43 & erg hoog & constant \\
\hline Productiemedewerkers & 67 & erg hoog & - \\
\hline Monteurs & 48 & erg hoog & sterk dalend \\
\hline Mechanisch operators & 45 & erg hoog & constant \\
\hline Procesoperators & 37 & erg hoog & - \\
\hline Transportberoepen & 39 & erg hoog & stijgend \\
\hline Chauffeurs & 45 & erg hoog & sterk stijgend \\
\hline Economisch-administratieve beroepen & 12 & hoog & - \\
\hline Kantoorhulpen, inpakkers en colporteurs & 43 & erg hoog & - \\
\hline \multicolumn{4}{|l|}{ Specifieke groepen werkenden } \\
\hline Vrouwen & 21 & hoog & stijgend \\
\hline Jongeren & 29 & erg hoog & - \\
\hline Ouderen & 31 & erg hoog & constant \\
\hline Allochtonen & 49 & erg hoog & sterk stijgend \\
\hline Totaal & 29 & erg hoog & stijgend \\
\hline
\end{tabular}

Bron: ROA/CBS 
Tabel 2.3

Percentage werkenden dat regelmatig werkt met trillende apparaten, gemiddelde 2001-2002

\begin{tabular}{lrlll}
\hline & & & \\
& & typering & trend 2000-2002 \\
\hline Opleidingen & & & \\
Basisonderwijs & 9 & gemiddeld & sterk dalend \\
VMBO natuur en techniek & 10 & gemiddeld & - \\
MBO natuur en techniek & 22 & hoog & sterk stijgend \\
MBO economie & 7 & gemiddeld & sterk stijgend \\
& & & \\
Beroepen & 15 & hoog & stijgend \\
Technische, ambachts- en industrieberoepen & 13 & hoog & sterk dalend \\
Mechanisch operators & 15 & hoog & sterk stijgend \\
Procesoperators & 20 & hoog & - \\
Transportberoepen & 1 & laag & sterk dalend \\
Economisch-administratieve beroepen & 15 & hoog & sterk dalend \\
Verzorgende en dienstverlenende beroepen & & & \\
Specifieke groepen werkenden & 8 & gemiddeld & sterk dalend \\
Vrouwen & 14 & hoog & - \\
Jongeren & 10 & gemiddeld & sterk stijgend \\
Ouderen & 13 & hoog & - \\
Allochtonen & 11 & gemiddeld & sterk stijgend \\
Totaal & & & \\
\hline Bron: ROA/CBS & & & \\
\hline
\end{tabular}

Bron: ROA/CBS 
Voeding

Tabel 2.4

Percentage werkenden dat regelmatig kracht moet zetten tijdens het werk, gemiddelde 2001-2002

\begin{tabular}{|c|c|c|c|}
\hline & $\%$ & typering & trend $2000-2002$ \\
\hline \multicolumn{4}{|l|}{ Opleidingen } \\
\hline Basisonderwijs & 44 & hoog & sterk stijgend \\
\hline VMBO theorie & 30 & gemiddeld & constant \\
\hline VMBO natuur en techniek & 38 & hoog & sterk dalend \\
\hline VMBO verzorging & 51 & erg hoog & sterk stijgend \\
\hline VMBO (uiterlijke) verzorging & 51 & erg hoog & sterk stijgend \\
\hline MBO natuur en techniek & 45 & hoog & sterk stijgend \\
\hline MBO brood en banket & 65 & erg hoog & sterk dalend \\
\hline MBO levensmiddelentechniek/vleesverwerking & 38 & hoog & - \\
\hline MBO economie & 13 & gemiddeld & - \\
\hline \multicolumn{4}{|l|}{ Beroepen } \\
\hline Technische, ambachts- en industrieberoepen & 41 & hoog & stijgend \\
\hline Productiemedewerkers & 35 & hoog & - \\
\hline Monteurs & 55 & erg hoog & - \\
\hline Mechanisch operators & 40 & hoog & dalend \\
\hline Procesoperators & 41 & hoog & sterk stijgend \\
\hline Transportberoepen & 47 & erg hoog & constant \\
\hline Chauffeurs & 44 & hoog & - \\
\hline Economisch-administratieve beroepen & 13 & gemiddeld & - \\
\hline Kantoorhulpen, inpakkers en colporteurs & 40 & hoog & sterk stijgend \\
\hline Verzorgende en dienstverlenende beroepen & 42 & hoog & sterk stijgend \\
\hline \multicolumn{4}{|l|}{ Specifieke groepen werkenden } \\
\hline Vrouwen & 25 & gemiddeld & sterk stijgend \\
\hline Jongeren & 39 & hoog & - \\
\hline Ouderen & 31 & hoog & - \\
\hline Allochtonen & 43 & hoog & sterk stijgend \\
\hline Totaal & 32 & hoog & sterk stijgend \\
\hline
\end{tabular}

Bron: ROA/CBS 
Tabel 2.5

Percentage werkenden dat regelmatig onder hoge tijdsdruk werkt, gemiddelde 2001-2002

\begin{tabular}{llll}
\hline & $\%$ & typering & trend 2000-2002 \\
& & & \\
Opleidingen & & & \\
Basisonderwijs & 26 & gemiddeld & stijgend \\
VMBO theorie & 23 & laag & - \\
VMBO natuur en techniek & 25 & laag & stijgend \\
MBO natuur en techniek & 30 & gemiddeld & dalend \\
MBO economie & 29 & gemiddeld & dalend \\
HO economie & 45 & erg hoog & - \\
& & & \\
Beroepen & & & \\
Technische, ambachts- en industrieberoepen & 28 & gemiddeld & constant \\
Mechanisch operators & 27 & gemiddeld & constant \\
Procesoperators & 26 & gemiddeld & dalend \\
Transportberoepen & 26 & gemiddeld & - \\
Economisch-administratieve beroepen & 36 & gemiddeld & stijgend \\
Kantoorhulpen, inpakkers en colporteurs & 32 & gemiddeld & sterk stijgend \\
Boekhouders en secretaresses & 36 & gemiddeld & - \\
Verzorgende en dienstverlenende beroepen & 21 & laag & sterk dalend \\
& & & \\
Specifieke groepen werkenden & & & \\
Vrouwen & 24 & laag & constant \\
Jongeren & 24 & laag & stijgend \\
Ouderen & 30 & gemiddeld & dalend \\
Allochtonen & 36 & gemiddeld & sterk stijgend \\
Totaal & 30 & gemiddeld & constant \\
& & & \\
\hline Bron: ROA/CBS & & &
\end{tabular}

Bron: ROA/CBS 
Voeding

Tabel 2.6

Percentage werkenden dat regelmatig beeldschermwerk verricht, gemiddelde 2001-2002

$\% \quad$ typering

trend 2000-2002

Opleidingen

Basisonderwijs

VMBO natuur en techniek

MBO natuur en techniek

MBO levensmiddelentechniek/vleesverwerking

MBO economie

MBO administratie

HO natuur en techniek

$\mathrm{HO}$ economie

WO bedrijfskunde

Beroepen

Technische, ambachts- en industrieberoepen

Monteurs

Mechanisch operators

Procesoperators

Economisch-administratieve beroepen

Receptionisten en administratieve employés

Boekhouders en secretaresses

Commercieel employés

Commercieel medewerkers

Specifieke groepen werkenden

Vrouwen

Jongeren

Ouderen

Allochtonen

Totaal

Bron: ROA/CBS sterk stijgend

sterk stijgend

dalend

gemiddeld

gemiddeld

gemiddeld

gemiddeld

gemiddeld

erg hoog

gemiddeld

dalend

sterk dalend

sterk dalend

constant

26 gemiddeld

29 gemiddeld

17 laag

34 gemiddeld

64 gemiddeld

72 gemiddeld

86 hoog

55 gemiddeld

87 hoog

-

31 gemiddeld sterk dalend

23 laag

35 gemiddeld

14 laag

34 gemiddeld dalend sterk stijgend

sterk dalend

constant

constant

sterk stijgend

$-$ 
Tabel 2.7

Percentage werkenden dat deelneemt aan scholingstrajecten korter dan 6 maanden, gemiddelde 2001-2002

$\%$ typering

3 laag

5 gemiddeld

3 laag

MBO natuur en techniek

MBO economie

Beroepen

Technische, ambachts- en industrieberoepen

Mechanisch operators

Procesoperators

Economisch-administratieve beroepen

Verzorgende en dienstverlenende beroepen

Specifieke groepen werkenden

Vrouwen

Jongeren

Ouderen

Allochtonen

Totaal

$\begin{array}{lll}4 & \text { gemiddeld } & \text { sterk dalend } \\ 2 & \text { laag } & \text { sterk dalend } \\ 5 & \text { gemiddeld } & - \\ 2 & \text { laag } & \text { sterk dalend } \\ 3 & \text { laag } & -\end{array}$

3 laag

3 laag

2 laag

0 erg laag

3 laag trend 2000-2002

sterk stijgend

sterk dalend

sterk dalend

-

sterk dalend

sterk dalend

Bron: ROA/CBS

Tabel 2.8

Percentage werkenden dat deelneemt aan scholingstrajecten van 6 maanden of langer, gemiddelde 20012002

$\% \quad$ typering

trend 2000-2002

Opleidingen

Basisonderwijs

MBO natuur en techniek

$\mathrm{MBO}$ economie

Beroepen

Technische, ambachts- en industrieberoepen

Mechanisch operators

Procesoperators

Economisch-administratieve beroepen

Verzorgende en dienstverlenende beroepen

Specifieke groepen werkenden

Vrouwen

Jongeren

Ouderen

Allochtonen

Totaal

$\begin{array}{rll}11 & \text { gemiddeld } & \text { sterk stijgend } \\ 8 & \text { laag } & \text { sterk dalend } \\ 13 & \text { gemiddeld } & -\end{array}$

12 gemiddeld sterk stijgend

12 gemiddeld sterk stijgend

19 hoog sterk stijgend

12 gemiddeld dalend

11 gemiddeld stijgend

$\begin{array}{rll}9 & \text { laag } & - \\ 30 & \text { erg hoog } & \text { sterk stijgend } \\ 2 & \text { erg laag } & - \\ 16 & \text { hoog } & - \\ 12 & \text { gemiddeld } & \text { stijgend }\end{array}$




\section{Voeding}

Tabel 2.9

Doelgroepen voor het scholingsbeleid en risicofactoren

Doelgroepen

Mechanische operators risicofactor(en)

krimpende werkgelegenheid 


\section{Chemie}



Tabel 3.1

Kernindicatoren

\section{Arbeidsomstandigheden}

Belastende arbeidsomstandigheden

$\%$ werknemers dat regelmatig geconfronteerd wordt met:

$\begin{array}{rrl}2000 & 2001 / 2002 & \text { typering } \\ \% & \% & \\ & & \\ 21 & 21 & \text { hoog } \\ 13 & 10 & \text { gemiddeld } \\ 22 & 21 & \text { gemiddeld } \\ 31 & 27 & \text { gemiddeld } \\ 54 & 50 & \text { gemiddeld }\end{array}$

Lawaai

Trilling

Kracht zetten

Tijdsdruk

Beeldschermwerk

Technologische en organisatorische ontwikkelingen

Organisatorische ontwikkelingen

\begin{tabular}{|c|c|}
\hline & $\begin{array}{l}\text { jiven } \\
\%\end{array}$ \\
\hline & $\begin{array}{l}57 \\
10 \\
24 \\
11\end{array}$ \\
\hline $\begin{array}{r}\text { werkenden } \\
\%\end{array}$ & $\begin{array}{r}\text { bedrijven } \\
\%\end{array}$ \\
\hline 74 & \\
\hline 26 & 48 \\
\hline
\end{tabular}

Vernieuwingen in het productieproces, 1999-2001

Automatisering, 2002

jaarlijks \%

Ingrijpende productverandering, 2000-2002

Veranderingen in positie, 2000-2002

Interne reorganisaties, 2000-2002

Verschuivingen in de werkgelegenheid

\section{Scholingsdeelname}

\begin{tabular}{|c|c|c|}
\hline 2000 & $2001 /$ & typering \\
\hline$\%$ & $\begin{array}{r}2002 \\
\%\end{array}$ & \\
\hline 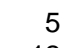 & 4 & yemiddeld \\
\hline 12 & 11 & yemiddeld \\
\hline
\end{tabular}

Deelname aan opleidingstrajecten korter dan 6 maanden (momentopname) Deelname aan opleidingstrajecten van 6 maanden of langer (momentopname) 


\section{Chemie}

\section{Risicoprofiel}

Figuur 3.1

Sectoraal risicoprofiel

\section{Chemie}

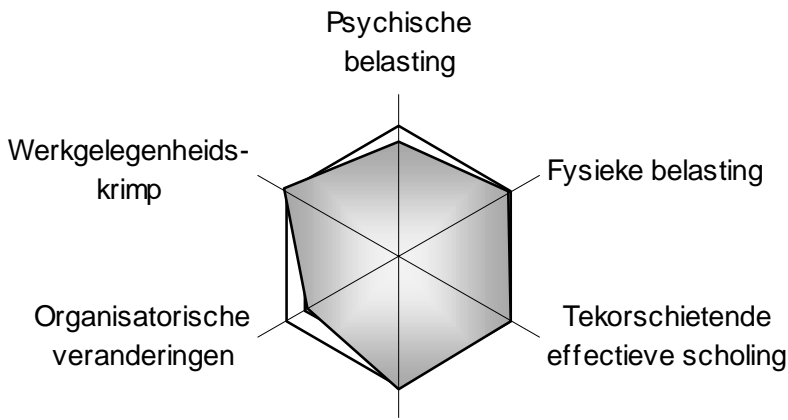

Informatisering

Tabel 3.2

Percentage werkenden dat regelmatig wordt geconfronteerd met lawaai tijdens het werk, gemiddelde 20012002

$\% \quad$ typering

Opleidingen

VMBO natuur en techniek

MBO natuur en techniek

MBO procestechniek

\section{Beroepen}

Technische, ambachts- en industrieberoepen

Monteurs

Mechanisch operators

Procesoperators

Economisch-administratieve beroepen

\section{Variabelen}

Vrouwen

Jongeren

Ouderen

Allochtonen

Totaal

Bron: ROA/CBS

trend 2000-2002

$\begin{array}{lll}39 & \text { erg hoog } & \text { sterk stijgend } \\ 28 & \text { hoog } & \text { constant } \\ 36 & \text { erg hoog } & \text { sterk dalend }\end{array}$

$\begin{array}{rll}28 & \text { hoog } & \text { constant } \\ 34 & \text { erg hoog } & - \\ 40 & \text { erg hoog } & - \\ 25 & \text { hoog } & \text { sterk dalend } \\ 7 & \text { gemiddeld } & \text { sterk stijgend } \\ & & \\ 11 & \text { gemiddeld } & \text { sterk stijgend } \\ 27 & \text { hoog } & \text { constant } \\ 20 & \text { hoog } & \text { constant } \\ 51 & \text { erg hoog } & - \\ 21 & \text { hoog } & -\end{array}$


Tabel 3.3

Percentage werkenden dat regelmatig werkt met trillende apparaten, gemiddelde 2001-2002

\begin{tabular}{|c|c|c|c|}
\hline & $\%$ & typering & trend $2000-2002$ \\
\hline \multicolumn{4}{|l|}{ Opleidingen } \\
\hline MBO natuur en techniek & 16 & hoog & sterk dalend \\
\hline \multicolumn{4}{|l|}{ Beroepen } \\
\hline Technische, ambachts- en industrieberoepen & 14 & hoog & sterk dalend \\
\hline Mechanische operators & 26 & hoog & - \\
\hline Procesoperators & 14 & hoog & sterk dalend \\
\hline \multicolumn{4}{|l|}{ Variabelen } \\
\hline Vrouwen & 6 & gemiddeld & constant \\
\hline Jongeren & 14 & hoog & sterk dalend \\
\hline Ouderen & 7 & gemiddeld & dalend \\
\hline Allochtonen & - & hoog & sterk stijgend \\
\hline Totaal & 10 & gemiddeld & sterk dalend \\
\hline
\end{tabular}

Bron: ROA/CBS

Tabel 3.4

Percentage werkenden dat regelmatig kracht moet zetten tijdens het werk, gemiddelde 2001-2002

\begin{tabular}{|c|c|c|c|}
\hline & $\%$ & typering & trend 2000-2002 \\
\hline \multicolumn{4}{|l|}{ Opleidingen } \\
\hline Basisonderwijs & 42 & hoog & sterk dalend \\
\hline VMBO natuur en techniek & 42 & hoog & sterk stijgend \\
\hline MBO natuur en techniek & 27 & gemiddeld & dalend \\
\hline MBO procestechniek & 31 & gemiddeld & stijgend \\
\hline \multicolumn{4}{|l|}{ Beroepen } \\
\hline Technische, ambachts- en industrieberoepen & 27 & gemiddeld & sterk dalend \\
\hline Monteurs & 58 & erg hoog & sterk stijgend \\
\hline Mechanisch operators & 41 & hoog & sterk dalend \\
\hline Procesoperators & 22 & gemiddeld & - \\
\hline Economisch-administratieve beroepen & 6 & gemiddeld & dalend \\
\hline \multicolumn{4}{|l|}{ Specifieke groepen werkenden } \\
\hline Vrouwen & 12 & gemiddeld & constant \\
\hline Jongeren & 25 & gemiddeld & sterk dalend \\
\hline Ouderen & 17 & gemiddeld & - \\
\hline Allochtonen & - & gemiddeld & - \\
\hline Totaal & 21 & gemiddeld & - \\
\hline
\end{tabular}

Bron: ROA/CBS 


\section{Chemie}

Tabel 3.5

Percentage werkenden dat regelmatig onder hoge tijdsdruk werkt, gemiddelde 2001-2002

\begin{tabular}{llll}
\hline & $\%$ & typering & trend 2000-2002 \\
& & & \\
\hline Opleidingen & & & \\
MBO natuur en techniek & 21 & laag & sterk dalend \\
MBO economie & 32 & gemiddeld & - \\
HO natuur en techniek & 41 & hoog & constant \\
HO economie & 49 & erg hoog & - \\
& & & \\
Beroepen & & & \\
Technische, ambachts- en industrieberoepen & 24 & laag & sterk dalend \\
Procesoperators & 24 & laag & sterk dalend \\
Economisch-administratieve beroepen & 33 & gemiddeld & - \\
& & & \\
Specifieke groepen werkenden & & & \\
Vrouwen & 23 & laag & - \\
Jongeren & 19 & laag & - \\
Ouderen & 29 & gemiddeld & dalend \\
Allochtonen & 28 & gemiddeld & - \\
Total & 27 & gemiddeld & dalend \\
& & & \\
\hline
\end{tabular}

Bron: ROA/CBS 
Tabel 3.6

Percentage werkenden dat regelmatig beeldschermwerk verricht, gemiddelde 2001-2002

\begin{tabular}{|c|c|c|c|}
\hline & $\%$ & typering & trend $2000-2002$ \\
\hline \multicolumn{4}{|l|}{ Opleidingen } \\
\hline VMBO theorie & 44 & gemiddeld & sterk dalend \\
\hline MBO natuur en techniek & 51 & gemiddeld & stijgend \\
\hline MBO laboratorium & 65 & gemiddeld & sterk dalend \\
\hline MBO elektrotechniek & 61 & gemiddeld & - \\
\hline MBO procestechniek & 54 & gemiddeld & sterk stijgend \\
\hline MBO economie & 72 & gemiddeld & - \\
\hline MBO administratie & 82 & hoog & constant \\
\hline HO natuur en techniek & 72 & gemiddeld & stijgend \\
\hline HBO laboratorium & 64 & gemiddeld & constant \\
\hline HO economie & 90 & hoog & - \\
\hline \multicolumn{4}{|l|}{ Beroepen } \\
\hline Technische, ambachts- en industrieberoepen & 41 & gemiddeld & constant \\
\hline Laboranten & 63 & gemiddeld & stijgend \\
\hline Procesoperators & 55 & gemiddeld & constant \\
\hline Economisch-administratieve beroepen & 78 & hoog & constant \\
\hline Receptionisten en administratieve employés & 82 & hoog & - \\
\hline Boekhouders en secretaresses & 91 & erg hoog & constant \\
\hline Commercieel employés & 78 & hoog & stijgend \\
\hline Informatica beroepen & 96 & erg hoog & stijgend \\
\hline \multicolumn{4}{|l|}{ Specifieke groepen werkenden } \\
\hline Vrouwen & 61 & gemiddeld & dalend \\
\hline Jongeren & 46 & gemiddeld & stijgend \\
\hline Ouderen & 57 & gemiddeld & sterk stijgend \\
\hline Allochtonen & 31 & gemiddeld & - \\
\hline Totaal & 50 & gemiddeld & constant \\
\hline
\end{tabular}

Bron: ROA/CBS 


\section{Chemie}

Tabel 3.7

Percentage werkenden dat deelneemt aan scholingstrajecten korter dan 6 maanden, gemiddelde 2001-2002

\begin{tabular}{|c|c|c|c|}
\hline Actueel onderwijs $<6$ maanden & $\%$ & typering & trend $2000-2002$ \\
\hline \multicolumn{4}{|l|}{ Opleidingen } \\
\hline MBO natuur en techniek & 4 & gemiddeld & sterk dalend \\
\hline \multicolumn{4}{|l|}{ Beroepen } \\
\hline Technische, ambachts- en industrieberoepen & 4 & gemiddeld & sterk dalend \\
\hline Procesoperators & 4 & gemddeld & sterk dalend \\
\hline Economisch-administratieve beroepen & 4 & gemiddeld & - \\
\hline \multicolumn{4}{|l|}{ Specifieke groepen werkenden } \\
\hline Vrouwen & 6 & hoog & - \\
\hline Jongeren & 4 & gemiddeld & - \\
\hline Ouderen & 5 & gemiddeld & sterk dalend \\
\hline Allochtonen & - & erg laag & sterk dalend \\
\hline Totaal & 4 & gemiddeld & sterk dalend \\
\hline
\end{tabular}

Bron: ROA/CBS

Tabel 3.8

Percentage werkenden dat deelneemt aan scholingstrajecten van 6 maanden of langer, gemiddelde 2001

$\% \quad$ typering trend $2000-2002$

\section{Opleidingen}

MBO natuur en techniek

MBO procestechniek

\begin{tabular}{|c|c|c|}
\hline 16 & hoog & - \\
\hline 26 & erg hoog & - \\
\hline 12 & gemiddeld & dalend \\
\hline 20 & hoog & dalend \\
\hline 9 & laag & - \\
\hline 11 & gemiddeld & - \\
\hline 22 & erg hoog & - \\
\hline 2 & erg laag & constant \\
\hline & laag & sterk stijgend \\
\hline 11 & gemiddeld & constant \\
\hline
\end{tabular}

Beroepen

Technische, ambachts- en industrieberoepen

Procesoperators

Economisch-administratieve beroepen

Specifieke groepen werkenden

Vrouwen

Jongeren

Ouderen

Allochtonen

Totaal

11 gemiddeld constant

Bron: ROA/CBS 
4. Metalektro 

Tabel 4.1

Kernindicatoren

\section{Arbeidsomstandigheden}

Belastende arbeidsomstandigheden

$\%$ werknemers dat regelmatig geconfronteerd wordt met:

$\begin{array}{rrl}2000 & 2001 / 2002 & \text { typering } \\ \% & \% & \\ 30 & 27 & \text { hoog } \\ 22 & 20 & \text { hoog } \\ 29 & 26 & \text { gemiddeld } \\ 30 & 27 & \text { gemiddeld } \\ 39 & 43 & \text { gemiddeld }\end{array}$

Lawaai

Trilling

Kracht zetten

Tijdsdruk

Beeldschermwerk

Technologische en organisatorische ontwikkelingen

Organisatorische ontwikkelingen

bedrijven

Kleine productverandering, 2000-2002

Ingrijpende productverandering, 2000-2002

21

Veranderingen in positie, 2000-2002

Interne reorganisaties, 2000-2002

21

Technologische vernieuwingen

werkenden bedrijven

$\begin{array}{rr}\% & \% \\ 58 & - \\ 26 & 38 \\ - & 92\end{array}$

Vernieuwingen in het productieproces, 1999-2001

Automatisering, 2002

Verschuivingen in de werkgelegenheid

jaarlijks \%

Verwachte werkgelegenheidsontwikkeling, 2003-2008

\section{Scholingsdeelname}

Deelname aan opleidingstrajecten korter dan 6 maanden (momentopname)

54 gemiddeld Deelname aan opleidingstrajecten van 6 maanden of langer (momentopname)

9

Bron: ROA/CBS/OSA 


\section{Risicoprofiel}

Figuur 4.1

Sectoraal risicoprofiel

\section{Metalektro}

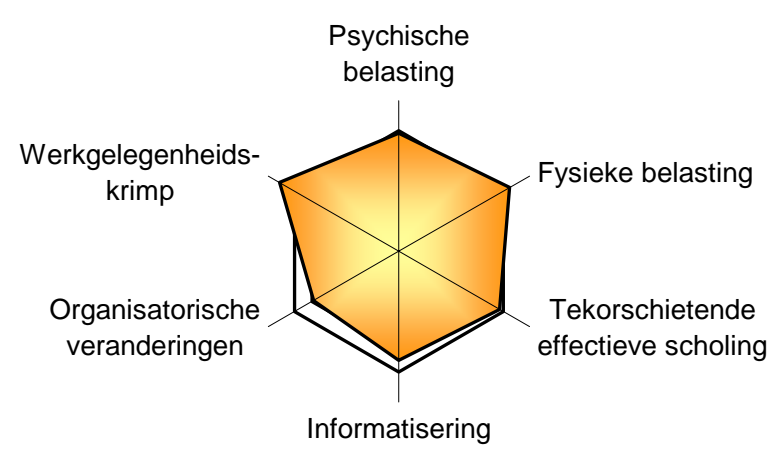

Tabel 4.2

Percentage werkenden dat regelmatig wordt geconfronteerd met lawaai tijdens het werk, gemiddelde 20012002

\section{Opleidingen}

Basisonderwijs

VMBO theorie

VMBO natuur en techniek

VMBO metaal: mechanische techniek

VMBO elektrotechniek

MBO natuur en techniek

MBO werktuigbouw en mechanische techniek

MBO elektrotechniek

MBO procestechniek

MBO economie

MBO dienstverlening en gezondheidszorg

$\mathrm{HO}$ natuur en techniek

$\mathrm{HBO}$ werktuigbouwkunde

$\mathrm{HO}$ economie

$\begin{aligned} 37 & \text { erg hoog } \\ 25 & \text { hoog } \\ 45 & \text { erg hoog } \\ 53 & \text { erg hoog } \\ 34 & \text { erg hoog } \\ 34 & \text { erg hoog } \\ 40 & \text { erg hoog } \\ 20 & \text { hoog } \\ 49 & \text { erg hoog } \\ 17 & \text { hoog } \\ 23 & \text { hoog } \\ 6 & \text { gemiddeld } \\ 9 & \text { gemiddeld } \\ 3 & \text { laag }\end{aligned}$

Beroepen

Technische, ambachts- en industrieberoepen

Productiemedewerkers

Bouwvakkers

Metaalarbeiders

Bankwerkers en lassers

Assembleurs

Monteurs

Economisch-administratieve beroepen

Boekhouders en secretaresses

$\begin{array}{rll}38 & \text { erg hoog } & \text { constant } \\ 28 & \text { hoog } & - \\ 42 & \text { erg hoog } & \text { sterk stijgend } \\ 56 & \text { erg hoog } & \text { constant } \\ 52 & \text { erg hoog } & - \\ 39 & \text { erg hoog } & - \\ 32 & \text { erg hoog } & \text { dalend } \\ 7 & \text { gemiddeld } & \text { sterk dalend } \\ 2 & \text { laag } & \text { sterk dalend } \\ & & \\ 10 & \text { gemiddeld } & \text { sterk stijgend } \\ 24 & \text { hoog } & \text { constant } \\ 29 & \text { erg hoog } & - \\ 37 & \text { erg hoog } & - \\ & & \\ 27 & \text { hoog } & \text { dalend }\end{array}$

Specifieke groepen werkenden

Vrouwen

Jongeren

Ouderen

Allochtonen

7 hoog

dalend

sterk dalend

sterk stijgend

sterk stijgend

constant

constant

constant

gemiddeld -

Bron: ROA/CBS 
Tabel 4.3

Percentage werkenden dat regelmatig werkt met trillende apparaten, gemiddelde 2001-2002

\begin{tabular}{|c|c|c|c|}
\hline & $\%$ & typering & trend $2000-2002$ \\
\hline \multicolumn{4}{|l|}{ Opleidingen } \\
\hline Basisonderwijs & 19 & hoog & - \\
\hline VMBO theorie & 19 & hoog & sterk stijgend \\
\hline VMBO natuur en techniek & 32 & erg hoog & constant \\
\hline VMBO metaal: mechanische techniek & 33 & erg hoog & constant \\
\hline VMBO elektrotechniek & 33 & erg hoog & sterk dalend \\
\hline MBO natuur en techniek & 29 & hoog & stijgend \\
\hline MBO werktuigbouw en mechanische techniek & 34 & erg hoog & constant \\
\hline MBO elektrotechniek & 17 & hoog & - \\
\hline MBO openbare orde en veiligheid & 44 & erg hoog & - \\
\hline MBO economie & 11 & gemiddeld & - \\
\hline HO natuur en techniek & 3 & gemiddeld & - \\
\hline HBO werktuigbouwkunde & 3 & gemiddeld & - \\
\hline \multicolumn{4}{|l|}{ Beroepen } \\
\hline Technische, ambachts- en industrieberoepen & 30 & hoog & dalend \\
\hline Bouwvakkers & 46 & erg hoog & constant \\
\hline Metaalarbeiders & 37 & erg hoog & dalend \\
\hline Bankwerkers en lassers & 45 & erg hoog & - \\
\hline Assembleurs & 41 & erg hoog & - \\
\hline Monteurs & 29 & hoog & sterk dalend \\
\hline Medische en paramedische beroepen & 36 & erg hoog & dalend \\
\hline Apothekersassistenten en medisch laboranten & 37 & erg hoog & - \\
\hline Economisch-administratieve beroepen & 0 & erg laag & sterk dalend \\
\hline \multicolumn{4}{|l|}{ Specifieke groepen werkenden } \\
\hline Vrouwen & 6 & gemiddeld & - \\
\hline Jongeren & 26 & hoog & stijgend \\
\hline Ouderen & 15 & hoog & - \\
\hline Allochtonen & 21 & hoog & - \\
\hline Totaal & 20 & hoog & dalend \\
\hline
\end{tabular}

Bron: ROA/CBS 


\section{Metalektro}

Tabel 4.4

Percentage werkenden dat regelmatig kracht moet zetten tijdens het werk, gemiddelde 2001-2002

$\% \quad$ typering trend $2000-2002$

Opleidingen

Basisonderwijs

VMBO theorie

VMBO natuur en techniek

VMBO metaal: mechanische techniek

VMBO elektrotechniek

MBO natuur en techniek

MBO werktuigbouw en mechanische techniek

MBO elektrotechniek

MBO openbare orde en veiligheid

MBO economie

$\mathrm{HO}$ natuur en techniek

$\mathrm{HBO}$ werktuigbouwkunde

$\mathrm{HO}$ economie

\section{4}

4

53

40

2

56

19

\section{Beroepen}

Technische, ambachts- en industrieberoepen

Bouwvakkers

Aannemers en installateurs

Metaalarbeiders

Bankwerkers en lassers

Assembleurs

Monteurs

Elektromonteurs

Transportberoepen

Laders en lossers

Economisch-administratieve beroepen

Boekhouders en secretaresses

Specifieke groepen werkenden

Vrouwen

Jongeren

Ouderen

Allochtonen

Totaal
22

30

36

hoog

gemiddeld

hoog constant

erg hoog stijgend

gemiddeld sterk dalend

hoog

hoog

gemiddeld

erg hoog

gemiddeld

laag

laag

laag

sterk stijgend

$-$

$-$

sterk stijgend

38 hoog constant

57 erg hoog sterk dalend

51 erg hoog constant

51 erghoog constant

48 erg hoog stijgend

38 hoog sterk dalend

40 hoog

21 gemiddeld sterk stijgend

33 hoog sterk dalend

42 hoog sterk dalend

5 gemiddeld sterk dalend

5 gemiddeld -

$\begin{array}{rll}7 & \text { gemiddeld } & \text { sterk dalend } \\ 30 & \text { gemiddeld } & - \\ 22 & \text { gemiddeld } & - \\ 33 & \text { hoog } & - \\ 26 & \text { gemiddeld } & \text { dalend }\end{array}$

Bron: ROA/CBS 
Tabel 4.5

Percentage werkenden dat regelmatig onder hoge tijdsdruk werkt, gemiddelde 2001-2002

\begin{tabular}{|c|c|c|c|}
\hline & $\%$ & typering & trend $2000-2002$ \\
\hline \multicolumn{4}{|l|}{ Opleidingen } \\
\hline Basisonderwijs & 19 & laag & sterk dalend \\
\hline VMBO theorie & 22 & laag & - \\
\hline VMBO natuur en techniek & 20 & laag & dalend \\
\hline VMBO metaal: mechanische techniek & 19 & laag & dalend \\
\hline MBO natuur en techniek & 25 & laag & - \\
\hline MBO werktuigbouw en mechanische techniek & 24 & laag & sterk dalend \\
\hline MBO elektrotechniek & 28 & gemiddeld & constant \\
\hline MBO economie & 32 & gemiddeld & stijgend \\
\hline $\mathrm{HO}$ natuur en techniek & 38 & gemiddeld & constant \\
\hline HBO werktuigbouwkunde & 45 & erg hoog & constant \\
\hline HBO elektrotechniek & 31 & gemiddeld & constant \\
\hline $\mathrm{HO}$ economie & 42 & hoog & constant \\
\hline HBO bedrijfskunde & 42 & hoog & stijgend \\
\hline \multicolumn{4}{|l|}{ Beroepen } \\
\hline Technische, ambachts- en industrieberoepen & 25 & laag & dalend \\
\hline Metaalarbeiders & 18 & erg laag & - \\
\hline Bankwerkers en lassers & 21 & laag & dalend \\
\hline Monteurs & 28 & gemiddeld & sterk dalend \\
\hline Werktuigbouwkundig ontwerpers en hoofden technische dienst & 41 & hoog & sterk dalend \\
\hline Elektromonteurs & 28 & gemiddeld & sterk dalend \\
\hline Transportberoepen & 24 & laag & stijgend \\
\hline Economisch-administratieve beroepen & 32 & gemiddeld & constant \\
\hline Boekhouders en secretaresses & 20 & laag & sterk dalend \\
\hline Commercieel employés & 38 & gemiddeld & stijgend \\
\hline Commercieel medewerkers & 53 & erg hoog & - \\
\hline Managers & 67 & erg hoog & dalend \\
\hline Informatica beroepen & 29 & gemiddeld & constant \\
\hline \multicolumn{4}{|l|}{ Specifieke groepen werkenden } \\
\hline Vrouwen & 22 & laag & - \\
\hline Jongeren & 19 & laag & stijgend \\
\hline Ouderen & 29 & gemiddeld & - \\
\hline Allochtonen & 25 & laag & - \\
\hline Totaal & 27 & gemiddeld & - \\
\hline
\end{tabular}

Bron: ROA/CBS 
Tabel 4.6

Percentage werkenden dat regelmatig beeldschermwerk verricht, gemiddelde 2001-2002

\begin{tabular}{|c|c|c|c|}
\hline & $\%$ & typering & trend $2000-2002$ \\
\hline \multicolumn{4}{|l|}{ Opleidinaen } \\
\hline Basisonderwijs & 11 & laag & - \\
\hline VMBO theorie & 44 & gemiddeld & - \\
\hline VMBO natuur en techniek & 14 & laag & stijgend \\
\hline VMBO metaal: mechanische techniek & 14 & laag & - \\
\hline VMBO economie & 44 & gemiddeld & sterk stijgend \\
\hline VMBO administratie, handel en mode & 50 & gemiddeld & - \\
\hline HAVO/VWO & 62 & gemiddeld & constant \\
\hline MBO natuur en techniek & 34 & gemiddeld & constant \\
\hline MBO werktuigbouw en mechanische techniek & 30 & gemiddeld & dalend \\
\hline MBO elektrotechniek & 44 & gemiddeld & sterk stijgend \\
\hline MBO procestechniek & 49 & gemiddeld & - \\
\hline MBO economie & 72 & gemiddeld & - \\
\hline MBO administratie & 84 & hoog & sterk stijgend \\
\hline MBO handel & 65 & gemiddeld & sterk stijgend \\
\hline MBO secretariaat & 93 & erg hoog & constant \\
\hline MBO dienstverlening en gezondheidszorg & 35 & gemiddeld & - \\
\hline HO natuur en techniek & 87 & hoog & stijgend \\
\hline HBO werktuigbouwkunde & 89 & hoog & sterk stijgend \\
\hline HBO elektrotechniek & 98 & erg hoog & stijgend \\
\hline HBO informatica & 96 & erg hoog & constant \\
\hline WO wiskunde en natuurwetenschappen & 74 & gemiddeld & sterk stijgend \\
\hline WO werktuigbouwkunde & 82 & hoog & - \\
\hline HO economie & 91 & erg hoog & constant \\
\hline HBO commerciële economie & 100 & erg hoog & sterk stijgend \\
\hline HBO bedrijfskunde & 88 & hoog & constant \\
\hline WO bedrijfskunde & 85 & hoog & - \\
\hline $\mathrm{HO}$ onderwijs en sociaal-cultureel & 88 & hoog & sterk stijgend \\
\hline \multicolumn{4}{|l|}{ Beroepen } \\
\hline Technische, ambachts- en industrieberoepen & 24 & gemiddeld & constant \\
\hline Werktuigbouwkundigen & 97 & erg hoog & sterk stijgend \\
\hline Metaalarbeiders & 8 & laag & sterk dalend \\
\hline Bankwerkers en lassers & 15 & laag & - \\
\hline Monteurs & 24 & gemiddeld & - \\
\hline Werktuigbouwkundig ontwerpers en hoofden technische dienst & 78 & hoog & stijgend \\
\hline Elektromonteurs & 44 & gemiddeld & - \\
\hline Transportberoepen & 37 & gemiddeld & sterk stijgend \\
\hline Laders en lossers & 50 & gemiddeld & - \\
\hline Economisch-administratieve beroepen & 85 & hoog & stijgend \\
\hline Productieplanners & 83 & hoog & sterk stijgend \\
\hline Receptionisten en administratieve employés & 84 & hoog & sterk stijgend \\
\hline Boekhouders en secretaresses & 97 & erg hoog & constant \\
\hline Assistent accountants & 89 & hoog & sterk dalend \\
\hline Commercieel employés & 86 & hoog & constant \\
\hline Commercieel medewerkers & 89 & hoog & - \\
\hline Managers & 65 & gemiddeld & - \\
\hline Informatica beroepen & 98 & erg hoog & stijgend \\
\hline Programmeurs & 100 & erg hoog & constant \\
\hline Systeemanalisten & 98 & erg hoog & stijgend \\
\hline
\end{tabular}


Tabel 4.6 (vervolg)

Percentage werkenden dat regelmatig beeldschermwerk verricht, gemiddelde 2001-2002

\begin{tabular}{lllll}
\hline & $\%$ & typering & trend 2000-2002 \\
& & & \\
Specifieke groepen werkenden & & & \\
Vrouwen & 64 & gemiddeld & stijgend \\
Jongeren & 40 & gemiddeld & - \\
Ouderen & 43 & gemiddeld & constant \\
Allochtonen & 20 & laag & sterk stijgend \\
Totaal & 43 & gemiddeld & stijgend \\
\hline Bron: & & &
\end{tabular}

Bron: ROA/CBS

Tabel 4.7

Percentage werkenden dat deelneemt aan scholingstrajecten korter dan 6 maanden, gemiddelde 2001-2002

$\% \quad$ typering trend $2000-2002$

\section{Opleidingen}

Basisonderwijs

VMBO theorie

VMBO natuur en techniek

VMBO metaal: mechanische techniek

MBO natuur en techniek

MBO werktuigbouw en mechanische techniek

MBO elektrotechniek

MBO economie

$\mathrm{HO}$ natuur en techniek

$\mathrm{HO}$ economie

\section{Beroepen}

Technische, ambachts- en industrieberoepen

Metaalarbeiders

Bankwerkers en lassers

Monteurs

Economisch-administratieve beroepen

Boekhouders en secretaresses

\section{laag \\ laag \\ laag \\ laag \\ gemiddeld \\ gemiddeld \\ gemiddeld \\ gemiddeld \\ gemiddeld \\ gemiddeld}

sterk stijgend

sterk dalend

sterk dalend

sterk dalend

constant

sterk dalend

sterk dalend

4 gemiddeld

3 laag

4 gemiddeld

5 gemiddeld

3 laag

2 laag

$\begin{array}{lll}3 & \text { laag } & \text { sterk dalend } \\ 6 & \text { hoog } & - \\ 2 & \text { laag } & - \\ 5 & \text { gemiddeld } & - \\ & & \\ 4 & \text { gemiddeld } & \text { sterk dalend }\end{array}$

4 gemiddeld

sterk dalend

sterk dalend

sterk dalend

sterk dalend

sterk dalend

erk dalend

Specifieke groepen werkenden

Vrouwen

Jongeren

Ouderen

Allochtonen

Totaal

Bron: ROA/CBS 


\section{Metalektro}

Tabel 4.8

Percentage werkenden dat deelneemt aan scholingstrajecten van 6 maanden of langer, gemiddelde 20012002

$\% \quad$ typering trend $2000-2002$

Opleidingen

Basisonderwijs

VMBO theorie

VMBO natuur en techniek

VMBO metaal: mechanische techniek

MBO natuur en techniek

MBO werktuigbouw en mechanische techniek

MBO elektrotechniek

MBO economie

$\mathrm{HO}$ natuur en techniek

$\mathrm{HO}$ economie

$\begin{array}{rll}6 & \text { erg laag } & \text { sterk dalend } \\ 15 & \text { hoog } & \text { sterk stijgend } \\ 9 & \text { laag } & - \\ 8 & \text { laag } & \text { constant } \\ 9 & \text { laag } & - \\ 6 & \text { erg laag } & - \\ 14 & \text { gemiddeld } & \text { sterk stijgend } \\ 10 & \text { gemiddeld } & - \\ 6 & \text { erg laag } & \text { stijgend } \\ 9 & \text { laag } & \text { sterk dalend }\end{array}$

Beroepen

Technische, ambachts- en industrieberoepen

Metaalarbeiders

Bankwerkers en lassers

Monteurs

Economisch-administratieve beroepen

Boekhouders en secretaresses

$\begin{array}{rll}9 & \text { laag } & \text { constant } \\ 10 & \text { gemiddeld } & \text { sterk dalend } \\ 5 & \text { erg laag } & - \\ 10 & \text { gemiddeld } & - \\ 8 & \text { laag } & \text { constant } \\ 9 & \text { laag } & -\end{array}$

Specifieke groepen werkenden

Vrouwen

9 laag sterk dalend

Jongeren

20 hoog

-

Ouderen

2 erg laag sterk dalend

Allochtonen

10 gemiddeld

sterk stijgend

Totaal

9 laag

constant

Bron: ROA/CBS

Tabel 4.9

Doelgroepen voor het scholingsbeleid en risicofactoren

Doelgroepen

Bouwvakkers

Metaalarbeiders

Bankwerkers en lassers

Managers

Commercieel medewerkers

Werktuigbouwkundig ontwerpers en hoofden technische dienst risicofactor(en)

fysieke belasting

fysieke belasting

fysieke belasting

tijdsdruk

tijdsdruk

krimpende werkgelegenheid 
5. Overige industrie 

Tabel 5.1

Kernindicatoren

\section{Arbeidsomstandigheden}

Belastende arbeidsomstandigheden

$\%$ werknemers dat regelmatig geconfronteerd wordt met:

$\begin{array}{rrl}2000 & 2001 / 2002 & \text { typering } \\ \% & \% & \\ & & \\ 24 & 23 & \text { hoog } \\ 15 & 15 & \text { hoog } \\ 26 & 25 & \text { gemiddeld } \\ 28 & 25 & \text { laag } \\ 35 & 37 & \text { gemiddeld }\end{array}$

Lawaai

Trilling

Kracht zetten

Tijdsdruk

Beeldschermwerk

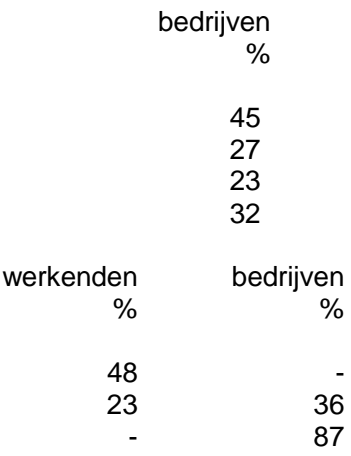

Vernieuwingen in het productieproces, 1999-2001

Automatisering, 2002

jaarlijks \%

Verschuivingen in de werkgelegenheid

Verwachte werkgelegenheidsontwikkeling, 2003-2008

Scholingsdeelname

$\begin{array}{lrr}\text { Scholingsdeelname } & 2000 & 2001 / \text { typering } \\ 2002 & \% \\ & \% & \% \\ \text { Deelname aan opleidingstrajecten korter dan 6 maanden (momentopname) } & 3 & 3 \text { laag } \\ \text { Deelname aan opleidingstrajecten van 6 maanden of langer (momentopname) } & 7 & 7 \text { laag }\end{array}$

Bron: ROA/CBS/OSA 


\section{Overige industrie}

\section{Risicoprofiel}

Figuur 5.1

Sectoraal risicoprofiel

\section{Overige industrie}

Psychische

belasting

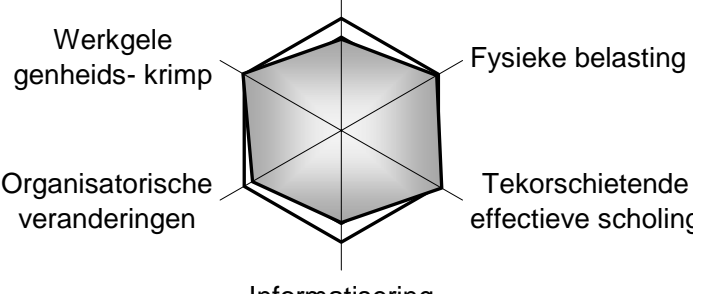

Informatisering

Tabel 5.2

Percentage werkenden dat regelmatig wordt geconfronteerd met lawaai tijdens het werk, gemiddelde 20012002

\section{Opleidingen}

Basisonderwijs

VMBO theorie

VMBO natuur en techniek

VMBO bouwtechniek

VMBO metaal: mechanische techniek

VMBO verzorging

VMBO verzorging

VMBO (uiterlijke) verzorging

MBO natuur en techniek

MBO bouw

MBO grafische techniek

MBO economie

$\mathrm{HO}$ economie

$\begin{array}{rll}26 & \text { hoog } & \text { stijgend } \\ 18 & \text { hoog } & \text { constant } \\ 37 & \text { erg hoog } & - \\ 34 & \text { erg hoog } & \text { sterk dalend } \\ 41 & \text { erg hoog } & - \\ 21 & \text { hoog } & \text { dalend } \\ 21 & \text { hoog } & \text { dalend } \\ 21 & \text { hoog } & \text { dalend } \\ 33 & \text { erg hoog } & \text { constant } \\ 35 & \text { erg hoog } & \text { sterk dalend } \\ 32 & \text { erg hoog } & - \\ 14 & \text { hoog } & \text { sterk stijgend } \\ 3 & \text { laag } & -\end{array}$

Beroepen

Culturele beroepen

Technische, ambachts- en industrieberoepen

Productiemedewerkers

Bouwvakkers

Aannemers en installateurs

Metaalarbeiders

Monteurs

Grafisch productiepersonee

Grafische vakkrachten

Mechanisch operators

Procesoperators

Confectie-arbeiders

Transportberoepen

Chauffeurs

Economisch-administratieve beroepen

Kantoorhulpen, inpakkers en colporteurs

Boekhouders en secretaresses

Commercieel employés

$\begin{array}{ll}\text { erg laag } & - \\ \text { erg hoog } & \text { dalend } \\ \text { erg hoog } & \text { sterk stijgend } \\ \text { erg hoog } & \text { sterk dalend } \\ \text { erg hoog } & \text { dalend } \\ \text { erg hoog } & - \\ \text { erg hoog } & \text { constant } \\ \text { hoog } & \text { constant } \\ \text { erg hoog } & \text { sterk stijgend } \\ \text { erg hoog } & \text { sterk stijgend } \\ \text { erg hoog } & \text { sterk dalend } \\ \text { hoog } & - \\ \text { hoog } & \text { sterk stijgend } \\ \text { erg hoog } & \text { sterk stijgend } \\ \text { gemiddeld } & \text { sterk dalend } \\ \text { hoog } & \text { sterk stijgend } \\ \text { gemiddeld } & \text { sterk dalend } \\ \text { gemiddeld } & \text { sterk dalend }\end{array}$


Tabel 5.2 (vervolg)

Percentage werkenden dat regelmatig wordt geconfronteerd met lawaai tijdens het werk, gemiddelde 20012002

$\% \quad$ typering trend 2000-2002

Specifieke groepen werkenden

Vrouwen

Jongeren

Ouderen

Allochtonen

emiddeld

Totaal

hoog sterk dalend

hoog

constant

29 erg hoog constant

Bron: ROA/CBS

Tabel 5.3

Percentage werkenden dat regelmatig werkt met trillende apparaten, gemiddelde 2001-2002

\begin{tabular}{|c|c|c|c|}
\hline & $\%$ & typering & trend $2000-2002$ \\
\hline \multicolumn{4}{|l|}{ Opleidingen } \\
\hline Basisonderwijs & 15 & hoog & constant \\
\hline VMBO theorie & 9 & gemiddeld & - \\
\hline VMBO natuur en techniek & 31 & hoog & - \\
\hline VMBO bouwtechniek & 31 & hoog & - \\
\hline VMBO metaal: mechanische techniek & 38 & erg hoog & - \\
\hline MBO natuur en techniek & 19 & hoog & sterk dalend \\
\hline MBO bouw & 34 & erg hoog & sterk dalend \\
\hline MBO grafische techniek & 13 & hoog & - \\
\hline MBO economie & 9 & gemiddeld & - \\
\hline $\mathrm{HO}$ economie & 1 & laag & - \\
\hline $\mathrm{HO}$ onderwijs en sociaal-cultureel & 2 & laag & sterk dalend \\
\hline \multicolumn{4}{|l|}{ Beroepen } \\
\hline Agrarische beroepen & 22 & hoog & - \\
\hline Technische, ambachts- en industrieberoepen & 26 & hoog & constant \\
\hline Bouwvakkers & 46 & erg hoog & - \\
\hline Aannemers en installateurs & 45 & erg hoog & constant \\
\hline Monteurs & 29 & hoog & sterk dalend \\
\hline Grafisch productiepersoneel & 17 & hoog & constant \\
\hline Grafische vakkrachten & 22 & hoog & - \\
\hline Confectie-arbeiders & 30 & hoog & - \\
\hline Transportberoepen & 6 & gemiddeld & - \\
\hline Economisch-administratieve beroepen & 3 & gemiddeld & sterk dalend \\
\hline Kantoorhulpen, inpakkers en colporteurs & 11 & gemiddeld & sterk stijgend \\
\hline Boekhouders en secretaresses & 2 & laag & constant \\
\hline Commercieel employés & 0 & erg laag & - \\
\hline \multicolumn{4}{|l|}{ Specifieke groepen werkenden } \\
\hline Vrouwen & 5 & gemiddeld & sterk stijgend \\
\hline Jongeren & 16 & hoog & - \\
\hline Ouderen & 11 & gemiddeld & sterk dalend \\
\hline Allochtonen & 14 & hoog & - \\
\hline Totaal & 15 & hoog & dalend \\
\hline
\end{tabular}

Bron: ROA/CBS 


\section{Overige industrie}

Tabel 5.4

Percentage werkenden dat regelmatig kracht moet zetten tijdens het werk, gemiddelde 2001-2002

\begin{tabular}{|c|c|c|c|}
\hline & $\%$ & typering & trend $2000-2002$ \\
\hline \multicolumn{4}{|l|}{ Opleidingen } \\
\hline Basisonderwijs & 33 & hoog & stijgend \\
\hline VMBO theorie & 32 & hoog & constant \\
\hline VMBO natuur en techniek & 41 & hoog & constant \\
\hline VMBO landbouw en natuurlijke omgeving & 56 & erg hoog & sterk stijgend \\
\hline VMBO bouwtechniek & 47 & erg hoog & - \\
\hline VMBO metaal: mechanische techniek & 33 & hoog & constant \\
\hline VMBO verzorging & 22 & gemiddeld & - \\
\hline VMBO (uiterlijke) verzorging & 22 & gemiddeld & - \\
\hline MBO natuur en techniek & 29 & gemiddeld & - \\
\hline MBO bouw & 34 & hoog & sterk dalend \\
\hline MBO grafische techniek & 29 & gemiddeld & - \\
\hline MBO economie & 13 & gemiddeld & - \\
\hline MBO handel & 25 & gemiddeld & sterk stijgend \\
\hline $\mathrm{HO}$ economie & 2 & laag & \\
\hline \multicolumn{4}{|l|}{ Beroepen } \\
\hline Culturele beroepen & 1 & laag & sterk dalend \\
\hline Agrarische beroepen & 35 & hoog & sterk stijgend \\
\hline Agrarische arbeiders & 32 & hoog & sterk stijgend \\
\hline Technische, ambachts- en industrieberoepen & 37 & hoog & dalend \\
\hline Productiemedewerkers & 43 & hoog & - \\
\hline Bouwvakkers & 57 & erg hoog & - \\
\hline Aannemers en installateurs & 46 & hoog & constant \\
\hline Metaalarbeiders & 51 & erg hoog & - \\
\hline Monteurs & 41 & hoog & stijgend \\
\hline Grafisch productiepersoneel & 28 & gemiddeld & - \\
\hline Grafische vakkrachten & 38 & hoog & sterk dalend \\
\hline Mechanisch operators & 40 & hoog & constant \\
\hline Confectie-arbeiders & 30 & gemiddeld & constant \\
\hline Transportberoepen & 31 & gemiddeld & - \\
\hline Laders en lossers & 43 & hoog & - \\
\hline Economisch-administratieve beroepen & 9 & gemiddeld & sterk dalend \\
\hline Kantoorhulpen, inpakkers en colporteurs & 35 & hoog & - \\
\hline Boekhouders en secretaresses & 4 & gemiddeld & - \\
\hline Commercieel employés & 1 & laag & - \\
\hline Verzorgende en dienstverlenende beroepen & 26 & gemiddeld & sterk stijgend \\
\hline \multicolumn{4}{|l|}{ Specifieke groepen werkenden } \\
\hline Vrouwen & 11 & gemiddeld & sterk dalend \\
\hline Jongeren & 30 & gemiddeld & constant \\
\hline Ouderen & 21 & gemiddeld & sterk stijgend \\
\hline Allochtonen & 33 & hoog & constant \\
\hline Totaal & 25 & gemiddeld & constant \\
\hline
\end{tabular}

Bron: ROA/CBS 
Tabel 5.5

Percentage werkenden dat regelmatig onder hoge tijdsdruk werkt, gemiddelde 2001-2002

\begin{tabular}{|c|c|c|c|}
\hline & $\%$ & typering & trend $2000-2002$ \\
\hline \multicolumn{4}{|l|}{ Opleidingen } \\
\hline Basisonderwijs & 14 & erg laag & dalend \\
\hline VMBO theorie & 21 & laag & dalend \\
\hline VMBO natuur en techniek & 16 & erg laag & dalend \\
\hline HAVO/VWO & 30 & gemiddeld & sterk dalend \\
\hline MBO natuur en techniek & 30 & gemiddeld & dalend \\
\hline MBO grafische techniek & 42 & hoog & - \\
\hline MBO economie & 29 & gemiddeld & constant \\
\hline MBO administratie & 33 & gemiddeld & sterk stijgend \\
\hline MBO handel & 26 & gemiddeld & sterk dalend \\
\hline $\mathrm{HO}$ natuur en techniek & 39 & hoog & sterk stijgend \\
\hline $\mathrm{HO}$ economie & 44 & erg hoog & dalend \\
\hline $\mathrm{HO}$ onderwijs en sociaal-cultureel & 40 & hoog & sterk dalend \\
\hline \multicolumn{4}{|l|}{ Beroepen } \\
\hline Culturele beroepen & 46 & erg hoog & - \\
\hline Journalisten & 61 & erg hoog & dalend \\
\hline Technische, ambachts- en industrieberoepen & 25 & laag & dalend \\
\hline Productiemedewerkers & 25 & laag & sterk dalend \\
\hline Bouwvakkers & 16 & erg laag & - \\
\hline Aannemers en installateurs & 27 & gemiddeld & sterk dalend \\
\hline Grafisch productiepersoneel & 34 & gemiddeld & dalend \\
\hline Grafische vakkrachten & 43 & hoog & constant \\
\hline Transportberoepen & 17 & erg laag & constant \\
\hline Economisch-administratieve beroepen & 26 & gemiddeld & constant \\
\hline Kantoorhulpen, inpakkers en colporteurs & 10 & erg laag & dalend \\
\hline Boekhouders en secretaresses & 18 & erg laag & constant \\
\hline Commercieel employés & 34 & gemiddeld & constant \\
\hline Commercieel medewerkers & 42 & hoog & dalend \\
\hline \multicolumn{4}{|l|}{ Specifieke groepen werkenden } \\
\hline Vrouwen & 24 & laag & - \\
\hline Jongeren & 20 & laag & - \\
\hline Ouderen & 22 & laag & sterk dalend \\
\hline Allochtonen & 24 & laag & constant \\
\hline Totaal & 25 & laag & dalend \\
\hline
\end{tabular}

Bron: ROA/CBS 
Tabel 5.6

Percentage werkenden dat regelmatig beeldschermwerk verricht, gemiddelde 2001-2002

\begin{tabular}{|c|c|c|c|}
\hline & $\%$ & typering & trend $2000-2002$ \\
\hline \multicolumn{4}{|l|}{ Opleidingen } \\
\hline Basisonderwijs & 8 & laag & sterk dalend \\
\hline VMBO theorie & 31 & gemiddeld & sterk dalend \\
\hline VMBO natuur en techniek & 11 & laag & sterk stijgend \\
\hline VMBO bouwtechniek & 6 & erg laag & - \\
\hline VMBO economie & 45 & gemiddeld & sterk stijgend \\
\hline VMBO administratie, handel en mode & 50 & gemiddeld & - \\
\hline HAVO/VWO & 63 & gemiddeld & - \\
\hline MBO natuur en techniek & 40 & gemiddeld & - \\
\hline MBO grafische techniek & 56 & gemiddeld & constant \\
\hline MBO automatisering & 89 & hoog & stijgend \\
\hline MBO economie & 64 & gemiddeld & constant \\
\hline MBO administratie & 86 & hoog & sterk stijgend \\
\hline MBO handel & 30 & gemiddeld & sterk dalend \\
\hline MBO secretariaat & 86 & hoog & - \\
\hline MBO bedrijfskunde & 74 & gemiddeld & sterk stijgend \\
\hline MBO dienstverlening en gezondheidszorg & 46 & gemiddeld & sterk stijgend \\
\hline HO natuur en techniek & 84 & hoog & constant \\
\hline $\mathrm{HO}$ economie & 87,2 & hoog & stijgend \\
\hline HBO commerciële economie & 95,5 & erg hoog & sterk stijgend \\
\hline HBO bedrijfskunde & 76,7 & hoog & sterk stijgend \\
\hline $\mathrm{HO}$ onderwijs en sociaal-cultureel & 84,4 & hoog & constant \\
\hline HBO communicatie en journalistiek & 100 & erg hoog & stijgend \\
\hline HBO uitvoerende en beeldende kunsten & 82,6 & hoog & - \\
\hline \multicolumn{4}{|l|}{ Beroepen } \\
\hline Culturele beroepen & 91 & erg hoog & constant \\
\hline Journalisten & 100 & erg hoog & constant \\
\hline Technische, ambachts- en industrieberoepen & 20 & laag & constant \\
\hline Bouwvakkers & 5 & erg laag & sterk dalend \\
\hline Grafisch productiepersoneel & 53 & gemiddeld & constant \\
\hline Grafische vakkrachten & 26 & gemiddeld & sterk dalend \\
\hline Transportberoepen & 13 & laag & - \\
\hline Economisch-administratieve beroepen & 70 & gemiddeld & sterk stijgend \\
\hline Kantoorhulpen, inpakkers en colporteurs & 2 & erg laag & constant \\
\hline Productieplanners & 90 & hoog & - \\
\hline Organisatie-adviseurs & 93 & erg hoog & sterk stijgend \\
\hline Receptionisten en administratieve employés & 74 & gemiddeld & constant \\
\hline Boekhouders en secretaresses & 92 & erg hoog & sterk stijgend \\
\hline Assistent accountants & 100 & erg hoog & constant \\
\hline Commercieel employés & 78 & hoog & - \\
\hline Commercieel medewerkers & 93 & erg hoog & stijgend \\
\hline Informatica beroepen & 100 & erg hoog & constant \\
\hline Programmeurs & 100 & erg hoog & constant \\
\hline Systeemanalisten & 100 & erg hoog & constant \\
\hline \multicolumn{4}{|l|}{ Specifieke groepen werkenden } \\
\hline Vrouwen & 51 & gemiddeld & constant \\
\hline Jongeren & 38 & gemiddeld & sterk dalend \\
\hline Ouderen & 35 & gemiddeld & - \\
\hline Allochtonen & 16 & laag & - \\
\hline Totaal & 37 & gemiddeld & - \\
\hline
\end{tabular}

Bron: ROA/CBS 
Tabel 5.7

Percentage werkenden dat deelneemt aan scholingstrajecten korter dan 6 maanden, gemiddelde 2001-2002

\begin{tabular}{|c|c|c|c|}
\hline & $\%$ & typering & trend $2000-2002$ \\
\hline \multicolumn{4}{|l|}{ Opleidingen } \\
\hline Basisonderwijs & 2 & laag & constant \\
\hline VMBO theorie & 2 & laag & sterk dalend \\
\hline VMBO natuur en techniek & 4 & gemiddeld & - \\
\hline HAVO/VWO & 4 & gemiddeld & - \\
\hline MBO natuur en techniek & 3 & laag & sterk dalend \\
\hline MBO grafische techniek & 2 & laag & - \\
\hline MBO economie & 5 & gemiddeld & sterk stijgend \\
\hline HO economie & 7 & hoog & sterk stijgend \\
\hline HO onderwijs en sociaal-cultureel & 2 & laag & - \\
\hline \multicolumn{4}{|l|}{ Beroepen } \\
\hline Culturele beroepen & 2 & laag & sterk stijgend \\
\hline Technische, ambachts- en industrieberoepen & 3 & laag & - \\
\hline Bouwvakkers & 2 & laag & dalend \\
\hline Grafisch productiepersoneel & 2 & laag & - \\
\hline Grafische vakkrachten & 2 & laag & sterk dalend \\
\hline Transportberoepen & 2 & laag & sterk dalend \\
\hline Economisch-administratieve beroepen & 4 & gemiddeld & - \\
\hline Kantoorhulpen, inpakkers en colporteurs & 1 & erg laag & constant \\
\hline Boekhouders en secretaresses & 4 & gemiddeld & - \\
\hline Commercieel employés & 6 & hoog & - \\
\hline \multicolumn{4}{|l|}{ Specifieke groepen werkenden } \\
\hline Vrouwen & 3 & laag & - \\
\hline Jongeren & 3 & laag & sterk stijgend \\
\hline Ouderen & 3 & laag & - \\
\hline Allochtonen & 1 & erg laag & stijgend \\
\hline Totaal & 3 & laag & constant \\
\hline
\end{tabular}

Bron: ROA/CBS 


\section{Overige industrie}

Tabel 5.8

Percentage werkenden dat deelneemt aan scholingstrajecten van 6 maanden of langer, gemiddelde 20012002

$\% \quad$ typering trend $2000-2002$

Opleidingen

Basisonderwijs

VMBO theorie

VMBO natuur en techniek

HAVO/VWO

MBO natuur en techniek

MBO grafische techniek

MBO economie

$\mathrm{HO}$ economie

$\mathrm{HO}$ onderwijs en sociaal-cultureel

Beroepen

Culturele beroepen

Technische, ambachts- en industrieberoepen

Bouwvakkers

Grafisch productiepersoneel

Grafische vakkrachten

Transportberoepen

Economisch-administratieve beroepen

Kantoorhulpen, inpakkers en colporteurs

Boekhouders en secretaresses

Commercieel employés

$\begin{array}{rll}4 & \text { erg laag } & - \\ 9 & \text { laag } & \text { sterk dalend } \\ 7 & \text { laag } & \text { sterk stijgend } \\ 22 & \text { erg hoog } & \text { sterk stijgend } \\ 5 & \text { erg laag } & \text { sterk dalend } \\ 4 & \text { erg laag } & \text { sterk dalend } \\ 7 & \text { laag } & \text { sterk dalend } \\ 10 & \text { gemiddeld } & \text { constant } \\ 9 & \text { laag } & \text { sterk stijgend }\end{array}$

Specifieke groepen werkenden

Vrouwen

Jongeren

Ouderen

Allochtonen

laag

erg laag sterk dalend

erg laag -

erg laag -

erg laag -

erg laag -

gemiddeld .

gemiddeld

laag sterk stijgend

laag stijgend

Totaal

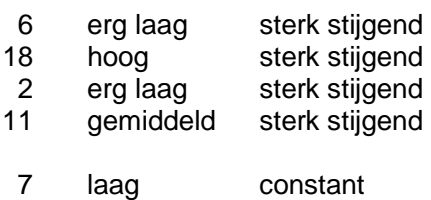

Bron: ROA/CBS

Tabel 5.9

Doelgroepen voor het scholingsbeleid en risicofactoren

Doelgroepen

risicofactor(en)

Journalisten

$\mathrm{RSI}$

Grafische vakkrachten

krimpende werkgelegenheid 
6. Energie 

Tabel 6.1

Kernindicatoren

\section{Arbeidsomstandigheden}

Belastende arbeidsomstandigheden

$\%$ werknemers dat regelmatig geconfronteerd wordt met:

$\begin{array}{rrl}2000 & 2001 / 2002 & \text { typering } \\ \% & \% & \\ 12 & 12 & \text { hoog } \\ 15 & 13 & \text { hoog } \\ 14 & 18 & \text { gemiddeld } \\ 30 & 29 & \text { gemiddeld } \\ 67 & 69 & \text { gemiddeld }\end{array}$

Lawaai

Trilling

Kracht zetten

Tijdsdruk

Beeldschermwerk

Technologische en organisatorische ontwikkelingen

Organisatorische ontwikkelingen

bedrijven

$\%$

Kleine productverandering, 2000-2002

Ingrijpende productverandering, 2000-2002

Veranderingen in positie, 2000-2002

Interne reorganisaties, 2000-2002

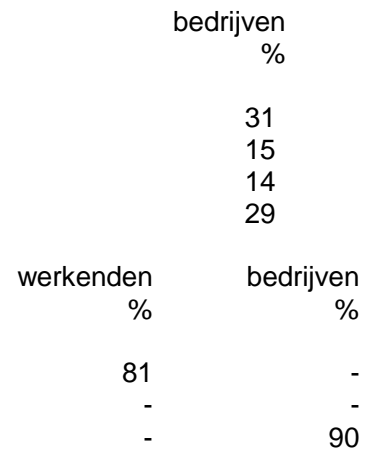

Vernieuwingen in het productieproces, 1999-2001

Automatisering, 2002

90

Verschuivingen in de werkgelegenheid

jaarlijks \%

Verwachte werkgelegenheidsontwikkeling, 2003-2008

0,4

Scholingsdeelname

Deelname aan opleidingstrajecten korter dan 6 maanden (momentopname)

Deelname aan opleidingstrajecten van 6 maanden of langer (momentopname)

$\begin{array}{rrr}2000 & 2001 / & \text { typering } \\ & 2002 & \\ \% & \% & \\ & & \\ 5 & 6 & \text { hoog } \\ 9 & 10 & \text { gemiddeld }\end{array}$

Bron: ROA/CBS/OSA 


\section{Energie}

\section{Risicoprofiel}

Figuur 6.1

Sectoraal risicoprofiel

\section{Energie}

Psychische belasting

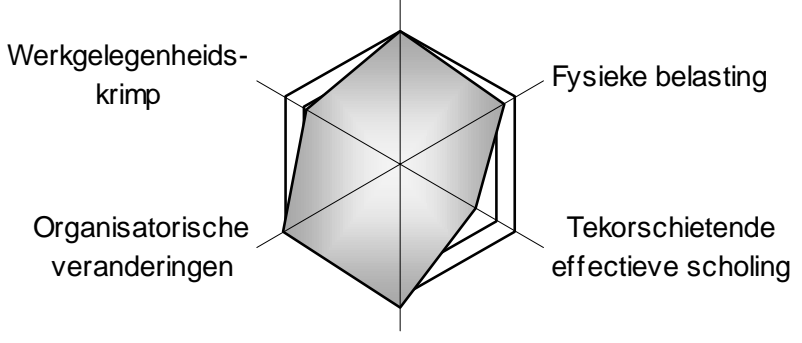

Informatisering

Tabel 6.2

Percentage werkenden dat regelmatig wordt geconfronteerd met lawaai tijdens het werk, gemiddelde 20012002

$\% \quad$ typering trend $2000-2002$

\section{Beroepen}

Technische, ambachts- en industrieberoepen

15

hoog

Specifieke groepen werkenden

Vrouwen

Jongeren

Ouderen

Allochtonen

Totaal

$\begin{array}{lll}- & \text { gemiddeld } & - \\ - & \text { hoog } & - \\ - & \text { gemiddeld } & - \\ - & - & - \\ 2 & \text { hoog } & -\end{array}$

Bron: ROA/CBS 
Tabel 6.3

Percentage werkenden dat regelmatig werkt met trillende apparaten, gemiddelde 2001-2002

\begin{tabular}{|c|c|c|c|}
\hline & $\%$ & typering & trend $2000-2002$ \\
\hline \multicolumn{4}{|l|}{ Opleidingen } \\
\hline MBO natuur en techniek & 26 & hoog & - \\
\hline \multicolumn{4}{|l|}{ Beroepen } \\
\hline Technische, ambachts- en industrieberoepen & 22 & hoog & - \\
\hline \multicolumn{4}{|l|}{ Specifieke groepen werkenden } \\
\hline Vrouwen & - & gemiddeld & - \\
\hline Jongeren & - & hoog & - \\
\hline Ouderen & - & hoog & - \\
\hline Allochtonen & - & - & - \\
\hline Totaal & 13 & hoog & constant \\
\hline
\end{tabular}

Bron: ROA/CBS

Tabel 6.4

Percentage werkenden dat regelmatig kracht moet zetten tijdens het werk, gemiddelde 2001-2002

\begin{tabular}{|c|c|c|c|}
\hline & $\%$ & typering & trend $2000-2002$ \\
\hline \multicolumn{4}{|l|}{ Opleidingen } \\
\hline MBO natuur en techniek & 29 & gemiddeld & - \\
\hline \multicolumn{4}{|l|}{ Beroepen } \\
\hline Technische, ambachts- en industrieberoepen & 28 & gemiddeld & constant \\
\hline \multicolumn{4}{|l|}{ Specifieke groepen werkenden } \\
\hline Vrouwen & - & gemiddeld & - \\
\hline Jongeren & - & gemiddeld & - \\
\hline Ouderen & 21 & gemiddeld & sterk stjgend \\
\hline Allochtonen & - & gemiddeld & - \\
\hline Totaal & 18 & gemiddeld & sterk stijgend \\
\hline
\end{tabular}

Bron: ROA/CBS 


\section{Energie}

Tabel 6.5

Percentage werkenden dat regelmatig onder hoge tijdsdruk werkt, gemiddelde 2001-2002

\begin{tabular}{|c|c|c|c|}
\hline & $\%$ & typering & trend $2000-2002$ \\
\hline \multicolumn{4}{|l|}{ Opleidingen } \\
\hline $\begin{array}{l}\text { MBO natuur en techniek } \\
\text { HO natuur en techniek }\end{array}$ & $\begin{array}{l}24 \\
34\end{array}$ & $\begin{array}{l}\text { laag } \\
\text { gemiddeld }\end{array}$ & $\begin{array}{l}\text { constant } \\
-\end{array}$ \\
\hline \multicolumn{4}{|l|}{ Beroepen } \\
\hline Technische, ambachts- en industrieberoepen & 26 & gemiddeld & - \\
\hline Economisch-administratieve beroepen & 32 & gemiddeld & dalend \\
\hline \multicolumn{4}{|l|}{ Specifieke groepen werkenden } \\
\hline Vrouwen & 34 & gemiddeld & constant \\
\hline Jongeren & - & laag & - \\
\hline Ouderen & 28 & gemiddeld & constant \\
\hline Allochtonen & - & erg laag & - \\
\hline Totaal & 29 & gemiddeld & dalend \\
\hline
\end{tabular}

Bron: ROA/CBS

Tabel 6.6

Percentage werkenden dat regelmatig beeldschermwerk verricht, gemiddelde 2001-2002

\begin{tabular}{lccl}
\hline & $\%$ & typering & trend 2000-2002 \\
& & & \\
\hline Opleidingen & & & \\
MBO natuur en techniek & 56 & gemiddeld & constant \\
MBO elektrotechniek & 48 & gemiddeld & - \\
MBO economie & 91 & erg hoog & dalend \\
HO natuur en techniek & 86 & hoog & dalend \\
HO economie & 93 & erg hoog & - \\
Beroepen & & & \\
Technische, ambachts- en industrieberoepen & 48 & gemiddeld & stijgend \\
Economisch-administratieve beroepen & 91 & erg hoog & stijgend \\
Receptionisten en administratieve employés & 84 & hoog & - \\
Boekhouders en secretaresses & 97 & erg hoog & constant \\
Specifieke groepen werkenden & & & \\
Vrouwen & & & \\
Jongeren & 93 & erg hoog & - \\
Ouderen & 68 & gemiddeld & sterk stijgend \\
Allochtonen & 66 & gemiddeld & stijgend \\
Total & - & gemiddeld & - \\
& 69 & gemiddeld & constant \\
\hline
\end{tabular}

Bron: ROA/CBS 
Tabel 6.7

Percentage werkenden dat deelneemt aan scholingstrajecten korter dan 6 maanden, gemiddelde 2001-2002

\begin{tabular}{|c|c|c|c|}
\hline & $\%$ & typering & trend $2000-2002$ \\
\hline \multicolumn{4}{|l|}{ Opleidingen } \\
\hline MBO natuur en techniek & 10 & erg hoog & sterk stijgend \\
\hline \multicolumn{4}{|l|}{ Beroepen } \\
\hline Technische, ambachts- en industrieberoepen & 8 & erg hoog & sterk stijgend \\
\hline Economisch-administratieve beroepen & 4 & gemiddeld & sterk dalend \\
\hline \multicolumn{4}{|l|}{ Specifieke groepen werkenden } \\
\hline Vrouwen & - & gemiddeld & - \\
\hline Jongeren & - & hoog & - \\
\hline Ouderen & - & laag & sterk dalend \\
\hline Allochtonen & - & - & - \\
\hline Totaal & 6 & hoog & sterk stijgend \\
\hline
\end{tabular}

Bron: ROA/CBS

Tabel 6.8

Percentage werkenden dat deelneemt aan scholingstrajecten van 6 maanden of langer, gemiddelde 20012002

$\% \quad$ typering trend 2000-2002

Opleidingen

dechniek

14 gemiddeld sterk stijgend

Beroepen

Technische, ambachts- en industrieberoepen

Economisch-administratieve beroepen

11 gemiddeld sterk stijgend

Specifieke groepen werkenden

Vrouwen

Jongeren

Ouderen

Allochtonen

10 gemiddeld sterk stijgend

Totaal

10 gemiddeld stijgend

Bron: ROA/CBS 

7. Bouw 

Tabel 7.1

Kernindicatoren

\section{Arbeidsomstandigheden}

Belastende arbeidsomstandigheden

$\%$ werknemers dat regelmatig geconfronteerd wordt met:

$\begin{array}{rrl}2000 & 2001 / 2002 & \text { typering } \\ \% & \% & \\ 14 & 16 & \text { hoog } \\ 29 & 30 & \text { hoog } \\ 43 & 45 & \text { hoog } \\ 28 & 25 & \text { laag } \\ 27 & 27 & \text { gemiddeld }\end{array}$

Lawaai

Trilling

Kracht zetten

Tijdsdruk

Beeldschermwerk

$\begin{array}{rrr} & \begin{array}{r}\text { bedrijven } \\ \%\end{array} \\ & & \\ & 33 & \\ & 24 & \\ & 11 & \\ & 20 & \\ & & \\ & & \\ \text { werkenden } & \text { bedrijven } \\ \% & & \% \\ 35 & & \\ 45 & & 27 \\ - & & 88\end{array}$

Vernieuwingen in het productieproces, 1999-2001

Automatisering, 2002

jaarlijks \%

Verschuivingen in de werkgelegenheid

Verwachte werkgelegenheidsontwikkeling, 2003-2008

\section{Scholingsdeelname}

\begin{tabular}{lrrr} 
& 2000 & $2001 /$ & typering \\
& $\%$ & $\begin{array}{r}2002 \\
\%\end{array}$ & \\
& 4 & 3 & laag \\
$\begin{array}{l}\text { Deelname aan opleidingstrajecten korter dan 6 maanden (momentopname) } \\
\text { Deelname aan opleidingstrajecten van 6 maanden of langer (momentopname) }\end{array}$ & 10 & 11 gemiddeld \\
\hline
\end{tabular}

Bron: ROA/CBS/OSA 


\section{Risicoprofiel}

Figuur 7.1

Sectoraal risicoprofiel

\section{Bouw}

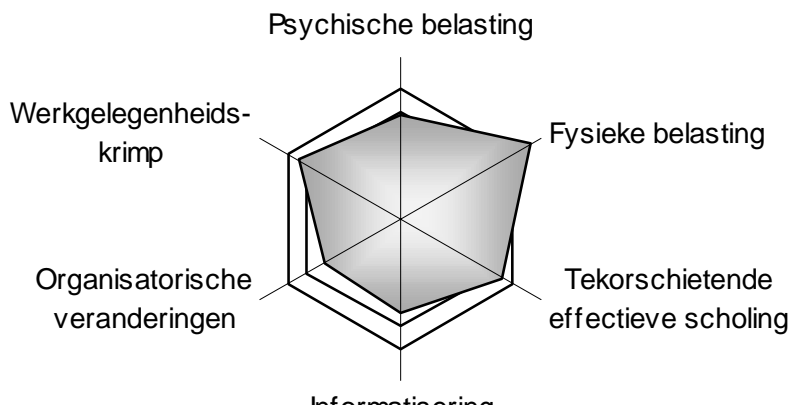

Informatisering

Tabel 7.2

Percentage werkenden dat regelmatig wordt geconfronteerd met lawaai tijdens het werk, gemiddelde 20012002

\begin{tabular}{|c|c|c|c|}
\hline & $\%$ & typering & trend $2000-2002$ \\
\hline \multicolumn{4}{|l|}{ Opleidingen } \\
\hline Basisonderwijs & 21 & hoog & sterk dalend \\
\hline VMBO theorie & 16 & hoog & sterk stijgend \\
\hline VMBO natuur en techniek & 22 & hoog & sterk stijgend \\
\hline VMBO bouwtechniek & 22 & hoog & sterk stijgend \\
\hline VMBO metaal: mechanische techniek & 28 & hoog & - \\
\hline VMBO elektrotechniek & 16 & hoog & - \\
\hline MBO natuur en techniek & 18 & hoog & sterk stijgend \\
\hline MBO bouw & 19 & hoog & sterk stijgend \\
\hline MBO grond-, weg- en waterbouw & 24 & hoog & sterk stijgend \\
\hline MBO elektrotechniek & 13 & hoog & - \\
\hline MBO economie & 5 & gemiddeld & sterk stijgend \\
\hline $\mathrm{HO}$ natuur en techniek & 5 & gemiddeld & sterk dalend \\
\hline \multicolumn{4}{|l|}{ Beroepen } \\
\hline Technische, ambachts- en industrieberoepen & 20 & hoog & sterk stijgend \\
\hline Productiemedewerkers & 24 & hoog & - \\
\hline Bouwvakkers & 20 & hoog & - \\
\hline Aannemers en installateurs & 18 & hoog & sterk stijgend \\
\hline Weg- en waterbouwkundige arbeiders & 33 & erg hoog & - \\
\hline Weg- en waterbouwkundige vakkrachten & 34 & erg hoog & - \\
\hline Monteurs & 35 & erg hoog & sterk stijgend \\
\hline Elektromonteurs & 14 & hoog & - \\
\hline Economisch-administratieve beroepen & 2 & laag & - \\
\hline
\end{tabular}


Tabel 7.2 (vervolg)

Percentage werkenden dat regelmatig wordt geconfronteerd met lawaai tijdens het werk, gemiddelde 20012002

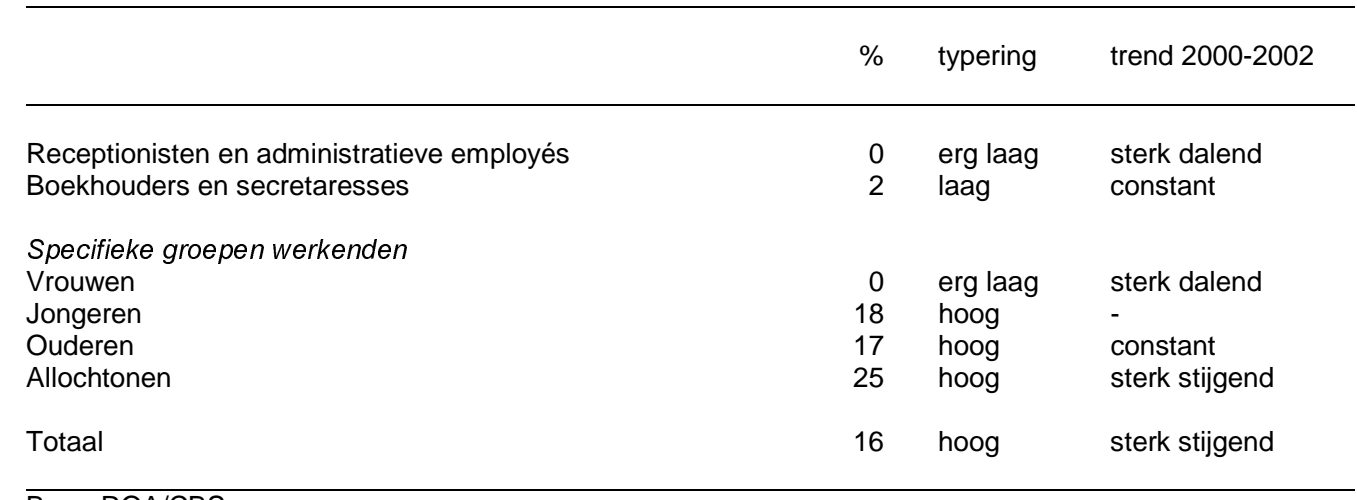

Bron: ROA/CBS

Tabel 7.3

Percentage werkenden dat regelmatig werkt met trillende apparaten, gemiddelde 2001-2002

$\% \quad$ typering trend $2000-2002$

Opleidingen

Basisonderwijs

VMBO theorie

VMBO natuur en techniek

VMBO bouwtechniek

VMBO metaal: mechanische techniek

VMBO elektrotechniek

VMBO economie

MBO natuur en techniek

MBO bouw

$\mathrm{MBO}$ grond-, weg- en waterbouw

MBO installatietechniek

MBO werktuigbouw en mechanische techniek

MBO elektrotechniek

MBO economie

$\mathrm{HO}$ natuur en techniek

$\mathrm{HO}$ economie

Beroepen

Technische, ambachts- en industrieberoepen

Productiemedewerkers

Bouwvakkers

Aannemers en installateurs

Weg-en waterbouwkundige arbeiders

Weg- en waterbouwkundige vakkrachten

Monteurs

Elektromonteurs

Economisch-administratieve beroepen

Receptionisten en administratieve employés

Boekhouders en secretaresses

Specifieke groepen werkenden

Vrouwen

Jongeren

$\begin{array}{ll}\text { erg hoog } & - \\ \text { hoog } & - \\ \text { erg hoog } & \text { sterk stijgend } \\ \text { erg hoog } & - \\ \text { erg hoog } & - \\ \text { erg hoog } & \text { sterk stijgend } \\ \text { hoog } & \text { sterk dalend } \\ \text { erg hoog } & \text { constant } \\ \text { erg hoog } & - \\ \text { erg hoog } & \text { sterk stijgend } \\ \text { erg hoog } & - \\ \text { hoog } & - \\ \text { hoog } & - \\ \text { gemiddeld } & - \\ \text { gemiddeld } & \text { constant } \\ \text { gemiddeld } & \text { sterk dalend }\end{array}$

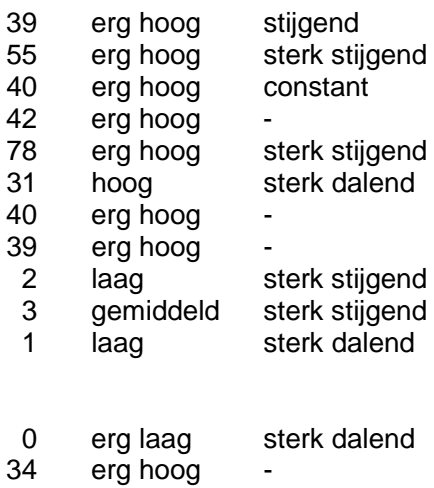




\section{Bouw}

Tabel 7.3 (vervolg)

Percentage werkenden dat regelmatig werkt met trillende apparaten, gemiddelde 2001-2002

\begin{tabular}{lcccc} 
& $\%$ & typering & trend 2000-2002 \\
\hline Ouderen & 25 & hoog & - \\
Allochtonen & 29 & hoog & - \\
Totaal & 30 & hoog & stijgend \\
\hline
\end{tabular}

Bron: ROA/CBS

Tabel 7.4

Percentage werkenden dat regelmatig kracht moet zetten tijdens het werk, gemiddelde 2001-2002

\begin{tabular}{|c|c|c|c|}
\hline & $\%$ & typering & trend $2000-2002$ \\
\hline \multicolumn{4}{|l|}{ Opleidingen } \\
\hline Basisonderwijs & 64 & erg hoog & dalend \\
\hline VMBO theorie & 37 & hoog & constant \\
\hline VMBO natuur en techniek & 68 & erg hoog & sterk stijgend \\
\hline VMBO bouwtechniek & 76 & erg hoog & sterk stijgend \\
\hline VMBO metaal: mechanische techniek & 70 & erg hoog & sterk stijgend \\
\hline VMBO voertuigentechniek & 76 & erg hoog & sterk stijgend \\
\hline VMBO elektrotechniek & 48 & erg hoog & - \\
\hline VMBO economie & 44 & hoog & sterk dalend \\
\hline MBO natuur en techniek & 46 & hoog & constant \\
\hline MBO bouw & 51 & erg hoog & constant \\
\hline MBO grond-, weg- en waterbouw & 41 & hoog & sterk stijgend \\
\hline MBO installatietechniek & 62 & erg hoog & constant \\
\hline MBO werktuigbouw en mechanische techniek & 37 & hoog & - \\
\hline MBO elektrotechniek & 31 & gemiddeld & dalend \\
\hline MBO economie & 18 & gemiddeld & sterk stijgend \\
\hline $\mathrm{HO}$ natuur en techniek & 5 & gemiddeld & - \\
\hline HO economie & 3 & laag & sterk dalend \\
\hline \multicolumn{4}{|l|}{ Beroepen } \\
\hline Technische, ambachts- en industrieberoepen & 57 & erg hoog & constant \\
\hline Productiemedewerkers & 74 & erg hoog & constant \\
\hline Bouwvakkers & 75 & erg hoog & - \\
\hline Aannemers en installateurs & 55 & erg hoog & stijgend \\
\hline Weg- en waterbouwkundige arbeiders & 85 & erg hoog & dalend \\
\hline Weg- en waterbouwkundige vakkrachten & 22 & gemiddeld & - \\
\hline Metaalarbeiders & 75 & erg hoog & sterk stijgend \\
\hline Monteurs & 46 & hoog & sterk stijgend \\
\hline Monteurs en controleurs elektrotechnische producten & 49 & erg hoog & stijgend \\
\hline Elektromonteurs & 42 & hoog & constant \\
\hline Economisch-administratieve beroepen & 3 & laag & constant \\
\hline Receptionisten en administratieve employés & 6 & gemiddeld & - \\
\hline Boekhouders en secretaresses & 4 & laag & sterk stijgend \\
\hline \multicolumn{4}{|l|}{ Specifieke groepen werkenden } \\
\hline Vrouwen & 5 & gemiddeld & sterk stijgend \\
\hline Jongeren & 54 & erg hoog & - \\
\hline Ouderen & 38 & hoog & _. \\
\hline Allochtonen & 52 & erg hoog & sterk stijgend \\
\hline Totaal & 45 & hoog & constant \\
\hline
\end{tabular}

Bron: ROA/CBS 
Tabel 7.5

Percentage werkenden dat regelmatig onder hoge tijdsdruk werkt, gemiddelde 2001-2002

\begin{tabular}{|c|c|c|c|}
\hline & $\%$ & typering & trend 2000-2002 \\
\hline \multicolumn{4}{|l|}{ Opleidingen } \\
\hline Basisonderwijs & 15 & erg laag & - \\
\hline VMBO theorie & 21 & laag & - \\
\hline VMBO natuur en techniek & 19 & laag & sterk dalend \\
\hline VMBO bouwtechniek & 17 & erg laag & sterk dalend \\
\hline VMBO metaal: mechanische techniek & 25 & laag & sterk dalend \\
\hline VMBO elektrotechniek & 21 & laag & sterk dalend \\
\hline HAVO/VWO & 24 & laag & - \\
\hline MBO natuur en techniek & 28 & gemiddeld & - \\
\hline MBO bouw & 27 & gemiddeld & dalend \\
\hline MBO grond-, weg- en waterbouw & 35 & gemiddeld & - \\
\hline MBO installatietechniek & 29 & gemiddeld & - \\
\hline MBO werktuigbouw en mechanische techniek & 24 & laag & sterk dalend \\
\hline MBO elektrotechniek & 30 & gemiddeld & - \\
\hline MBO economie & 25 & laag & constant \\
\hline MBO administratie & 20 & laag & sterk dalend \\
\hline $\mathrm{HO}$ natuur en techniek & 46 & erg hoog & dalend \\
\hline HBO bouwkunde & 47 & erg hoog & sterk dalend \\
\hline HO economie & 43 & hoog & - \\
\hline \multicolumn{4}{|l|}{ Beroepen } \\
\hline Technische, ambachts- en industrieberoepen & 25 & laag & dalend \\
\hline Bouwvakkers & 17 & erg laag & dalend \\
\hline Aannemers en installateurs & 29 & gemiddeld & sterk dalend \\
\hline Architecten en bouwkundig projectleiders & 51 & erg hoog & constant \\
\hline Weg- en waterbouwkundige arbeiders & 24 & laag & sterk dalend \\
\hline Weg- en waterbouwkundige vakkrachten & 31 & gemiddeld & sterk stijgend \\
\hline Monteurs & 27 & gemiddeld & constant \\
\hline Elektromonteurs & 24 & laag & dalend \\
\hline Economisch-administratieve beroepen & 27 & gemiddeld & sterk dalend \\
\hline Receptionisten en administratieve employés & 12 & erg laag & sterk dalend \\
\hline Boekhouders en secretaresses & 17 & erg laag & dalend \\
\hline Commercieel employés & 41 & hoog & dalend \\
\hline Commercieel medewerkers & 41 & hoog & sterk dalend \\
\hline \multicolumn{4}{|l|}{ Specifieke groepen werkenden } \\
\hline Vrouwen & 19 & laag & dalend \\
\hline Jongeren & 17 & erg laag & sterk dalend \\
\hline Ouderen & 30 & gemiddeld & - \\
\hline Allochtonen & 25 & laag & stijgend \\
\hline Totaal & 25 & laag & dalend \\
\hline
\end{tabular}

Bron: ROA/CBS 
Tabel 7.6

Percentage werkenden dat regelmatig beeldschermwerk verricht, gemiddelde 2001-2002

\begin{tabular}{|c|c|c|c|}
\hline & $\%$ & typering & trend $2000-2002$ \\
\hline \multicolumn{4}{|l|}{ Opleidingen } \\
\hline Basisonderwijs & 5 & erg laag & - \\
\hline VMBO theorie & 38 & gemiddeld & dalend \\
\hline VMBO natuur en techniek & 3 & erg laag & dalend \\
\hline VMBO bouwtechniek & 2 & erg laag & - \\
\hline VMBO metaal: mechanische techniek & 2 & erg laag & - \\
\hline VMBO elektrotechniek & 8 & laag & - \\
\hline VMBO economie & 32 & gemiddeld & sterk stijgend \\
\hline VMBO administratie, handel en mode & 45 & gemiddeld & sterk stijgend \\
\hline HAVO/VWO & 68 & gemiddeld & stijgend \\
\hline MBO natuur en techniek & 19 & laag & constant \\
\hline MBO bouw & 15 & laag & sterk dalend \\
\hline MBO werktuigbouw en mechanische techniek & 26 & gemiddeld & - \\
\hline MBO elektrotechniek & 29 & gemiddeld & sterk stijgend \\
\hline MBO economie & 74 & gemiddeld & dalend \\
\hline MBO administratie & 90 & hoog & constant \\
\hline MBO handel & 39 & gemiddeld & sterk dalend \\
\hline MBO secretariaat & 95 & erg hoog & constant \\
\hline MBO dienstverlening en gezondheidszorg & 65 & gemiddeld & stijgend \\
\hline $\mathrm{HO}$ natuur en techniek & 78 & hoog & constant \\
\hline HBO bouwkunde & 63 & gemiddeld & constant \\
\hline HBO civiele techniek & 90 & hoog & \\
\hline $\mathrm{HO}$ economie & 73 & gemiddeld & constant \\
\hline HBO commerciële economie & 86 & hoog & - \\
\hline $\mathrm{HBO}$ secretariaat & 100 & erg hoog & constant \\
\hline $\mathrm{HO}$ onderwijs en sociaal-cultureel & 83 & hoog & dalend \\
\hline \multicolumn{4}{|l|}{ Beroepen } \\
\hline Technische, ambachts- en industrieberoepen & 12 & laag & constant \\
\hline Bouwvakkers & 0 & erg laag & constant \\
\hline Aannemers en installateurs & 15 & laag & sterk dalend \\
\hline Architecten en bouwkundig projectleiders & 56 & gemiddeld & - \\
\hline Weg- en waterbouwkundige vakkrachten & 26 & gemiddeld & sterk stijgend \\
\hline Elektromonteurs & 11 & laag & - \\
\hline Economisch-administratieve beroepen & 85 & hoog & constant \\
\hline Receptionisten en administratieve employés & 93 & erg hoog & - \\
\hline Boekhouders en secretaresses & 95 & erg hoog & constant \\
\hline Assistent accountants & 87 & hoog & dalend \\
\hline Commercieel employés & 88 & hoog & sterk stijgend \\
\hline Commercieel medewerkers & 74 & gemiddeld & dalend \\
\hline Informatica beroepen & 100 & erg hoog & stijgend \\
\hline Programmeurs & 100 & erg hoog & stijgend \\
\hline \multicolumn{4}{|l|}{ Specifieke groepen werkenden } \\
\hline Vrouwen & 86 & hoog & constant \\
\hline Jongeren & 22 & laag & - \\
\hline Ouderen & 23 & laag & constant \\
\hline Allochtonen & 20 & laag & sterk dalend \\
\hline Totaal & 27 & gemiddeld & - \\
\hline
\end{tabular}

Bron: ROA/CBS 
Tabel 7.7

Percentage werkenden dat deelneemt aan scholingstrajecten korter dan 6 maanden, gemiddelde 2001-2002

\begin{tabular}{|c|c|c|c|}
\hline & $\%$ & typering & trend $2000-2002$ \\
\hline \multicolumn{4}{|l|}{ Opleidingen } \\
\hline Basisonderwijs & 2 & laag & sterk dalend \\
\hline VMBO theorie & 1 & erg laag & sterk dalend \\
\hline VMBO natuur en techniek & 3 & laag & sterk dalend \\
\hline VMBO bouwtechniek & 2 & laag & - \\
\hline VMBO metaal: mechanische techniek & 3 & laag & sterk dalend \\
\hline VMBO elektrotechniek & 3 & laag & sterk dalend \\
\hline MBO natuur en techniek & 4 & gemiddeld & dalend \\
\hline MBO bouw & 4 & gemiddeld & - \\
\hline MBO elektrotechniek & 5 & gemiddeld & - \\
\hline MBO economie & 4 & gemiddeld & - \\
\hline $\mathrm{HO}$ natuur en techniek & 5 & gemiddeld & sterk dalend \\
\hline $\mathrm{HO}$ economie & 6 & hoog & stijgend \\
\hline \multicolumn{4}{|l|}{ Beroepen } \\
\hline Technische, ambachts- en industrieberoepen & 3 & laag & sterk dalend \\
\hline Bouwvakkers & 2 & laag & sterk dalend \\
\hline Aannemers en installateurs & 4 & gemiddeld & - \\
\hline Architecten en bouwkundig projectleiders & 6 & hoog & constant \\
\hline Weg- en waterbouwkundige vakkrachten & 4 & gemiddeld & - \\
\hline Elektromonteurs & 4 & gemiddeld & - \\
\hline Economisch-administratieve beroepen & 4 & gemiddeld & constant \\
\hline Receptionisten en administratieve employés & 2 & laag & - \\
\hline Boekhouders en secretaresses & 4 & gemiddeld & - \\
\hline \multicolumn{4}{|l|}{ Specifieke groepen werkenden } \\
\hline Vrouwen & 3 & laag & - \\
\hline Jongeren & 2 & laag & sterk dalend \\
\hline Ouderen & 3 & laag & stijgend \\
\hline Allochtonen & - & laag & - \\
\hline Totaal & 3 & laag & sterk dalend \\
\hline
\end{tabular}

Bron: ROA/CBS 
Tabel 7.8

Percentage werkenden dat deelneemt aan scholingstrajecten van 6 maanden of langer, gemiddelde 20012002

$\% \quad$ typering trend 2000-2002

Opleidingen

Basisonderwijs

VMBO theorie

VMBO natuur en techniek

VMBO bouwtechniek

VMBO metaal: mechanische techniek

VMBO elektrotechniek

MBO natuur en techniek

$\mathrm{MBO}$ bouw

MBO elektrotechniek

$\mathrm{MBO}$ economie

$\mathrm{HO}$ natuur en techniek

$\mathrm{HO}$ economie

Beroepen

Technische, ambachts- en industrieberoepen

Bouwvakkers

Aannemers en installateurs

Architecten en bouwkundig projectleiders

Weg- en waterbouwkundige vakkrachten

Elektromonteurs

Economisch-administratieve beroepen

Receptionisten en administratieve employés

Boekhouders en secretaresses

Specifieke groepen werkenden

Vrouwen

Jongeren

Ouderen

Allochtonen

Totaal

\section{laag}

hoog

gemiddeld

gemiddeld

laag

erg hoog

laag

laag

gemiddeld

gemiddeld

gemiddeld

gemiddeld

sterk dalend

dalend

sterk stijgend

stijgend

constant

-

constant

sterk stijgend

gemiddeld constant

gemiddeld

gemiddeld

gemiddeld

erg laag

hoog

gemiddeld

laag

gemiddeld

sterk stijgend

stijgend

stijgend

8 laag sterk dalend

28 erg hoog

1 erg laag sterk dalend

- hoog

11 gemiddeld constant

Bron: ROA/CBS

Tabel 7.9

Doelgroepen voor het scholingsbeleid en risicofactoren

Doelgroepen

Bouwvakkers

Weg- en waterbouwkundige arbeiders

Productiemedewerkers risicofactor(en)

fysieke belasting

fysieke belasting

krimpende werkgelegenheid 
8. Handel 

Tabel 8.1

Kernindicatoren

\section{Arbeidsomstandigheden}

Belastende arbeidsomstandigheden

$\%$ werknemers dat regelmatig geconfronteerd wordt met:

$\begin{array}{rrl}2000 & 2001 / 2002 & \text { typering } \\ \% & \% & \\ 5 & 6 & \text { gemiddeld } \\ 7 & 7 & \text { gemideeld } \\ 26 & 27 & \text { gemiddeld } \\ 26 & 22 & \text { laag } \\ 38 & 40 & \text { gemiddeld }\end{array}$

Lawaai

Trilling

Kracht zetten

Tijdsdruk

Beeldschermwerk

$\begin{array}{rrr} & \begin{array}{r}\text { bedrijven } \\ \%\end{array} \\ & 40 \\ & 22 \\ & 21 & \\ & 17 & \\ & & \\ & & \\ \text { werkenden } & \text { bedrijven } \\ \% & & \\ & & \\ 57 & & \\ 34 & & \\ - & & 86\end{array}$

Vernieuwingen in het productieproces, 1999-2001

Automatisering, 2002

jaarlijks \%

Verschuivingen in de werkgelegenheid

Verwachte werkgelegenheidsontwikkeling, 2003-2008

\section{Scholingsdeelname}

\begin{tabular}{|c|c|c|c|}
\hline Sctiolingueerila & 2000 & $\begin{array}{r}2001 / \\
2002\end{array}$ & typering \\
\hline & $\%$ & $\%$ & \\
\hline Deelname aan opleidingstrajecten korter dan 6 maanden (momentopname) & 4 & 3 & laag \\
\hline Deelname aan opleidingstrajecten van 6 maanden of langer (momentopname) & 15 & 16 & hoog \\
\hline
\end{tabular}

Bron: ROA/CBS/OSA 


\section{Risicoprofiel}

Figuur 8.1

Sectoraal risicoprofiel

\section{Handel}

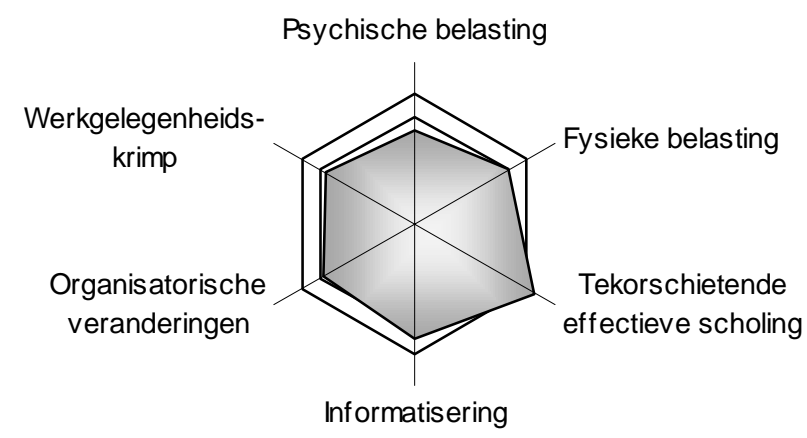

Tabel 8.2

Percentage werkenden dat regelmatig wordt geconfronteerd met lawaai tijdens het werk, gemiddelde 20012002

$\% \quad$ typering trend 2000-2002

Opleidingen

Basisonderwijs

VMBO theorie

VMBO natuur en techniek

VMBO economie

VMBO administratie, handel en mode

VMBO verzorging

VMBO (uiterlijke) verzorging

HAVO/VWO

MBO natuur en techniek

MBO motorvoertuigentechniek

MBO elektrotechniek

MBO economie

MBO administratie

MBO handel

MBO dienstverlening en gezondheidszorg

$\mathrm{HO}$ natuur en techniek

$\mathrm{HO}$ economie

HBO bedrijfskunde

$\mathrm{HO}$ onderwijs en sociaal-cultureel

$\begin{array}{lll}3 & \text { hoog } & \text { sterk stijgend } \\ 4 & \text { gemiddeld } & - \\ 3 & \text { hoog } & \text { sterk stijgend } \\ 4 & \text { gemiddeld } & \text { sterk stijgend } \\ 4 & \text { gemiddeld } & \text { sterk stijgend } \\ 2 & \text { laag } & \text { sterk dalend } \\ 2 & \text { laag } & \text { sterk dalend } \\ 2 & \text { laag } & \text { sterk dalend } \\ 1 & \text { gemiddeld } & \text { dalend } \\ 1 & \text { hoog } & \text { sterk stijgend } \\ 6 & \text { gemiddeld } & \text { sterk dalend } \\ 2 & \text { laag } & \text { sterk stijgend } \\ 3 & \text { laag } & \text { sterk stijgend } \\ 1 & \text { erg laag } & - \\ 3 & \text { laag } & - \\ 2 & \text { laag } & \text { sterk dalend } \\ 6 & \text { gemiddeld } & \text { sterk stijgend } \\ 5 & \text { hoog } & \text { sterk stijgend } \\ 1 & \text { erg laag } & \text { sterk dalend }\end{array}$


Tabel 8.2 (vervolg)

Percentage werkenden dat regelmatig wordt geconfronteerd met lawaai tijdens het werk, gemiddelde 20012002

$\% \quad$ typering trend 2000-2002

\section{Beroepen}

Technische, ambachts- en industrieberoepen

Productiemedewerkers

Monteurs

Technische, ambachts- en industrieberoepen

Productiemedewerkers

Transportberoepen

Laders en lossers

Chauffeurs

Economisch-administratieve beroepen

Receptionisten en administratieve employés

Boekhouders en secretaresses

Commercieel employés

Commercieel medewerkers

Verzorgende en dienstverlenende beroepen

Vakkenvullers

Verkopers

Winkeliers

21 hoog

sterk stijgend

sterk stijgend

26 hoog sterk stijgend

Specifieke groepen werkenden

Vrouwen

Jongeren

Ouderen

Allochtonen

Totaal

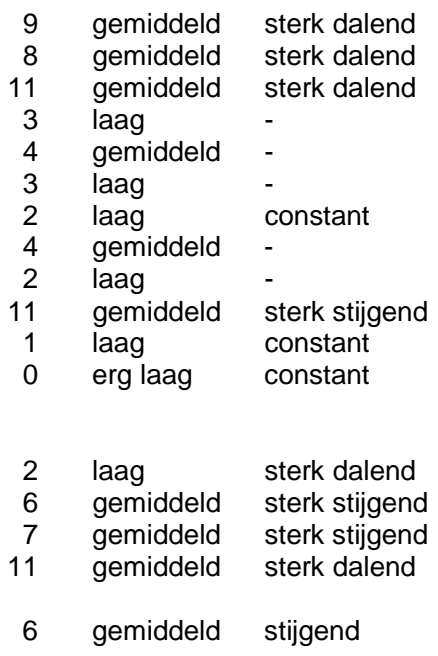

gemiddeld sterk dalend

sterk dalend

gemiddeld

gemiddeld

gemiddeld

sterk stijgend

Bron: ROA/CBS 
Tabel 8.3

Percentage werkenden dat regelmatig werkt met trillende apparaten, gemiddelde 2001-2002

\begin{tabular}{|c|c|c|c|}
\hline & $\%$ & typering & trend $2000-2002$ \\
\hline \multicolumn{4}{|l|}{ Opleidingen } \\
\hline Basisonderwijs & 11 & gemiddeld & sterk stijgend \\
\hline VMBO theorie & 5 & gemiddeld & sterk dalend \\
\hline VMBO natuur en techniek & 18 & hoog & stijgend \\
\hline VMBO voertuigentechniek & 26 & hoog & sterk dalend \\
\hline VMBO economie & 2 & laag & constant \\
\hline VMBO administratie, handel en mode & 2 & laag & - \\
\hline VMBO verzorging & 1 & laag & sterk dalend \\
\hline VMBO (uiterlijke) verzorging & 1 & laag & sterk dalend \\
\hline HAVO/VWO & 1 & laag & sterk dalend \\
\hline MBO natuur en techniek & 23 & hoog & stijgend \\
\hline MBO werktuigbouw en mechanische techniek & 23 & hoog & sterk stijgend \\
\hline MBO motorvoertuigentechniek & 47 & erg hoog & stijgend \\
\hline MBO elektrotechniek & 12 & gemiddeld & sterk stijgend \\
\hline MBO economie & 3 & gemiddeld & - \\
\hline MBO administratie & 3 & gemiddeld & sterk dalend \\
\hline MBO handel & 4 & gemiddeld & stijgend \\
\hline MBO dienstverlening en gezondheidszorg & 2 & laag & sterk dalend \\
\hline HO natuur en techniek & 4 & gemiddeld & sterk dalend \\
\hline HO onderwijs en sociaal-cultureel & 4 & gemiddeld & - \\
\hline \multicolumn{4}{|l|}{ Beroepen } \\
\hline Technische, ambachts- en industrieberoepen & 36 & erg hoog & stijgend \\
\hline Monteurs & 58 & erg hoog & stijgend \\
\hline Transportberoepen & 4 & gemiddeld & - \\
\hline Laders en lossers & 3 & gemiddeld & sterk stijgend \\
\hline Chauffeurs & 4 & gemiddeld & - \\
\hline Medische en paramedische beroepen & 6 & gemiddeld & sterk dalend \\
\hline Apothekersassistenten en medisch laboranten & 6 & gemiddeld & sterk dalend \\
\hline Economisch-administratieve beroepen & 1 & laag & - \\
\hline Receptionisten en administratieve employés & 1 & laag & - \\
\hline Boekhouders en secretaresses & 1 & laag & sterk dalend \\
\hline Commercieel employés & 0 & erg laag & - \\
\hline Commercieel medewerkers & 2 & laag & - \\
\hline Informatica beroepen & 1 & laag & sterk stijgend \\
\hline Verzorgende en dienstverlenende beroepen & 2 & laag & sterk dalend \\
\hline Vakkenvullers & 2 & laag & sterk dalend \\
\hline Verkopers & 2 & laag & - \\
\hline Winkeliers & 2 & laag & sterk dalend \\
\hline \multicolumn{4}{|l|}{ Specifieke groepen werkenden } \\
\hline Vrouwen & 1 & laag & sterk dalend \\
\hline Jongeren & 8 & gemiddeld & stijgend \\
\hline Ouderen & 6 & gemiddeld & - \\
\hline Allochtonen & 11 & gemiddeld & constant \\
\hline Totaal & 7 & gemiddeld & constant \\
\hline
\end{tabular}

Bron: ROA/CBS 
Tabel 8.4

Percentage werkenden dat regelmatig kracht moet zetten tijdens het werk, gemiddelde 2001-2002

\begin{tabular}{|c|c|c|c|}
\hline & $\%$ & typering & trend $2000-2002$ \\
\hline \multicolumn{4}{|l|}{ Opleidingen } \\
\hline Basisonderwijs & 39 & hoog & sterk stijgend \\
\hline VMBO theorie & 28 & gemiddeld & constant \\
\hline VMBO natuur en techniek & 52 & erg hoog & - \\
\hline VMBO landbouw en natuurlijke omgeving & 37 & hoog & - \\
\hline VMBO bouwtechniek & 58 & erg hoog & - \\
\hline VMBO metaal: mechanische techniek & 52 & erg hoog & - \\
\hline VMBO voertuigentechniek & 56 & erg hoog & - \\
\hline VMBO elektrotechniek & 54 & erg hoog & constant \\
\hline VMBO transport en logistiek & 67 & erg hoog & sterk stijgend \\
\hline VMBO economie & 29 & gemiddeld & - \\
\hline VMBO administratie, handel en mode & 24 & gemiddeld & - \\
\hline VMBO consumptief en levensmiddelentechniek & 48 & erg hoog & constant \\
\hline VMBO verzorging & 21 & gemiddeld & sterk dalend \\
\hline VMBO (uiterlijke) verzorging & 21 & gemiddeld & sterk dalend \\
\hline HAVO/VWO & 21 & gemiddeld & sterk stijgend \\
\hline MBO natuur en techniek & 37 & hoog & stijgend \\
\hline MBO landbouw en veeteelt & 43 & hoog & - \\
\hline MBO bouw & 38 & hoog & constant \\
\hline MBO werktuigbouw en mechanische techniek & 35 & hoog & sterk stijgend \\
\hline MBO motorvoertuigentechniek & 49 & erg hoog & constant \\
\hline MBO elektrotechniek & 20 & gemiddeld & sterk dalend \\
\hline MBO levensmiddelentechniek/vleesverwerking & 54 & erg hoog & constant \\
\hline MBO economie & 22 & gemiddeld & constant \\
\hline MBO administratie & 12 & gemiddeld & sterk dalend \\
\hline MBO handel & 29 & gemiddeld & sterk stijgend \\
\hline MBO dienstverlening en gezondheidszorg & 17 & gemiddeld & constant \\
\hline MBO apothekersassistent & 3 & laag & - \\
\hline MBO verzorging & 33 & hoog & - \\
\hline $\mathrm{HO}$ natuur en techniek & 8 & gemiddeld & - \\
\hline $\mathrm{HO}$ economie & 9 & gemiddeld & sterk stijgend \\
\hline HBO commerciële economie & 5 & gemiddeld & sterk dalend \\
\hline HBO bedrijfskunde & 17 & gemiddeld & sterk stijgend \\
\hline $\mathrm{HO}$ onderwijs en sociaal-cultureel & 18 & gemiddeld & sterk stijgend \\
\hline \multicolumn{4}{|l|}{ Beroepen } \\
\hline Agrarische beroepen & 39 & hoog & constant \\
\hline Technische, ambachts- en industrieberoepen & 46 & hoog & constant \\
\hline Productiemedewerkers & 60 & erg hoog & sterk stijgend \\
\hline Bouwvakkers & 72 & erg hoog & constant \\
\hline Metaalarbeiders & 50 & erg hoog & - \\
\hline Assembleurs & 51 & erg hoog & - \\
\hline Monteurs & 54 & erg hoog & constant \\
\hline Mechanisch operators & 50 & erg hoog & - \\
\hline Confectie-arbeiders & 54 & erg hoog & - \\
\hline Transportberoepen & 54 & erg hoog & dalend \\
\hline Laders en lossers & 60 & erg hoog & constant \\
\hline Chauffeurs & 48 & erg hoog & sterk dalend \\
\hline Medische en paramedische beroepen & 4 & gemiddeld & - \\
\hline Apothekersassistenten en medisch laboranten & 4 & gemiddeld & - \\
\hline Economisch-administratieve beroepen & 8 & gemiddeld & sterk dalend \\
\hline Receptionisten en administratieve employés & 7 & gemiddeld & sterk dalend \\
\hline Boekhouders en secretaresses & 5 & gemiddeld & - \\
\hline Commercieel employés & 9 & gemiddeld & - \\
\hline Commercieel medewerkers & 11 & gemiddeld & sterk stijgend \\
\hline Informatica beroepen & 0 & erg laag & sterk stijgend \\
\hline Verzorgende en dienstverlenende beroepen & 30 & gemiddeld & sterk stijgend \\
\hline Vakkenvullers & 60 & erg hoog & - \\
\hline
\end{tabular}




\section{Handel}

Tabel 8.4 (vervolg)

Percentage werkenden dat regelmatig kracht moet zetten tijdens het werk, gemiddelde 2001-2002

\begin{tabular}{|c|c|c|c|}
\hline & $\%$ & typering & trend 2000-2002 \\
\hline Verkopers & 25 & gemiddeld & stijgend \\
\hline Winkeliers & 35 & hoog & sterk stijgend \\
\hline \multicolumn{4}{|c|}{ Specifieke groepen werkenden } \\
\hline Vrouwen & 17 & gemiddeld & constant \\
\hline Jongeren & 33 & hoog & stijgend \\
\hline Ouderen & 21 & gemiddeld & dalend \\
\hline Allochtonen & 32 & hoog & sterk stijgend \\
\hline Totaal & 27 & gemiddeld & constant \\
\hline
\end{tabular}

Bron: ROA/CBS 
Tabel 8.5

Percentage werkenden dat regelmatig onder hoge tijdsdruk werkt, gemiddelde 2001-2002

\begin{tabular}{|c|c|c|c|}
\hline & $\%$ & typering & trend 2000-2002 \\
\hline \multicolumn{4}{|l|}{ Opleidingen } \\
\hline Basisonderwijs & 18 & erg laag & dalend \\
\hline VMBO theorie & 16 & erg laag & dalend \\
\hline VMBO natuur en techniek & 19 & laag & sterk dalend \\
\hline VMBO economie & 15 & erg laag & dalend \\
\hline VMBO administratie, handel en mode & 15 & erg laag & dalend \\
\hline VMBO verzorging & 14 & erg laag & - \\
\hline VMBO (uiterlijke) verzorging & 14 & erg laag & - \\
\hline HAVO/VWO & 22 & laag & - \\
\hline MBO natuur en techniek & 26 & gemiddeld & dalend \\
\hline MBO landbouw en veeteelt & 21 & laag & stijgend \\
\hline MBO werktuigbouw en mechanische techniek & 27 & gemiddeld & sterk dalend \\
\hline MBO motorvoertuigentechniek & 27 & gemiddeld & constant \\
\hline MBO elektrotechniek & 26 & gemiddeld & sterk dalend \\
\hline MBO economie & 23 & laag & sterk dalend \\
\hline MBO administratie & 21 & laag & sterk dalend \\
\hline MBO handel & 21 & laag & sterk dalend \\
\hline MBO secretariaat & 24 & laag & constant \\
\hline MBO bedrijfskunde & 41 & hoog & dalend \\
\hline MBO dienstverlening en gezondheidszorg & 22 & laag & - \\
\hline MBO apothekersassistent & 35 & gemiddeld & - \\
\hline MBO verzorging & 19 & laag & constant \\
\hline $\mathrm{HO}$ natuur en techniek & 36 & gemiddeld & constant \\
\hline HO economie & 39 & hoog & sterk dalend \\
\hline HBO accountancy en bedrijfseconomie & 42 & hoog & sterk dalend \\
\hline HBO commerciële economie & 37 & gemiddeld & dalend \\
\hline HBO bedrijfskunde & 38 & gemiddeld & sterk dalend \\
\hline WO bedrijfskunde & 52 & erg hoog & sterk dalend \\
\hline HO onderwiis en sociaal-cultureel & 26 & gemiddeld & dalend \\
\hline HO medisch & 42 & hoog & sterk stijgend \\
\hline \multicolumn{4}{|l|}{ Beroepen } \\
\hline Technische, ambachts- en industrieberoepen & 23 & laag & sterk dalend \\
\hline Monteurs & 23 & laag & sterk dalend \\
\hline Transportberoepen & 20 & laag & sterk dalend \\
\hline Laders en lossers & 21 & laag & - \\
\hline Chauffeurs & 17 & erg laag & sterk dalend \\
\hline Medische en paramedische beroepen & 31 & gemiddeld & - \\
\hline Apothekersassistenten en medisch laboranten & 30 & gemiddeld & - \\
\hline Economisch-administratieve beroepen & 30 & gemiddeld & dalend \\
\hline Productieplanners & 40 & hoog & - \\
\hline Receptionisten en administratieve employés & 16 & erg laag & constant \\
\hline Boekhouders en secretaresses & 23 & laag & constant \\
\hline Assistent accountants & 43 & hoog & constant \\
\hline Commercieel employés & 30 & gemiddeld & constant \\
\hline Commercieel medewerkers & 47 & erg hoog & constant \\
\hline Leidinggevenden & 45 & erg hoog & stijgend \\
\hline Informatica beroepen & 44 & erg hoog & constant \\
\hline Programmeurs & 37 & gemiddeld & - \\
\hline Systeemanalisten & 47 & erg hoog & stijgend \\
\hline Verzorgende en dienstverlenende beroepen & 15 & erq laag & sterk dalend \\
\hline Vakkenvullers & 15 & erg laag & sterk stijgend \\
\hline Verkopers & 12 & erg laag & sterk dalend \\
\hline Winkeliers & 25 & laag & sterk dalend \\
\hline
\end{tabular}




\section{Handel}

Tabel 8.5 (vervolg)

Percentage werkenden dat regelmatig onder hoge tijdsdruk werkt, gemiddelde 2001-2002

$\% \quad$ typering trend 2000-2002

Specifieke groepen werkenden

Vrouwen

Jongeren

Ouderen

17 erglaag dalend

Allochtonen

24 laag sterk dalend

Totaal

23 laag

sterk dalend

$22 \quad$ laag

dalend

Bron: ROA/CBS 
Tabel 8.6

Percentage werkenden dat regelmatig beeldschermwerk verricht, gemiddelde 2001-2002

\begin{tabular}{|c|c|c|c|}
\hline & $\%$ & typering & trend $2000-2002$ \\
\hline \multicolumn{4}{|l|}{ Opleidingen } \\
\hline Basisonderwijs & 18,2 & laag & sterk dalend \\
\hline VMBO theorie & 32,7 & gemiddeld & constant \\
\hline VMBO natuur en techniek & 17,9 & laag & - \\
\hline VMBO voertuigentechniek & 22,6 & laag & sterk dalend \\
\hline VMBO economie & 30,2 & gemiddeld & - \\
\hline VMBO administratie, handel en mode & 33,9 & gemiddeld & - \\
\hline VMBO verzorging & 20,4 & laag & sterk stijgend \\
\hline VMBO (uiterlijke) verzorging & 20,4 & laag & sterk stijgend \\
\hline HAVO/VWO & 43,8 & gemiddeld & sterk dalend \\
\hline MBO natuur en techniek & 33,6 & gemiddeld & stijgend \\
\hline MBO werktuigbouw en mechanische techniek & 49,7 & gemiddeld & sterk stijgend \\
\hline MBO motorvoertuigentechniek & 24,2 & gemiddeld & sterk stijgend \\
\hline MBO elektrotechniek & 45,1 & gemiddeld & constant \\
\hline MBO vervoer en logistiek & 66,4 & gemiddeld & - \\
\hline MBO automatisering & 79,1 & hoog & constant \\
\hline MBO economie & 48,9 & gemiddeld & constant \\
\hline MBO administratie & 72,5 & gemiddeld & stijgend \\
\hline MBO handel & 34,7 & gemiddeld & stijgend \\
\hline MBO secretariaat & 69,9 & gemiddeld & - \\
\hline MBO bedrijfskunde & 52,3 & gemiddeld & - \\
\hline MBO dienstverlening en gezondheidszorg & 48,6 & gemiddeld & constant \\
\hline MBO dokters-, tandarts- en dierenartsassistent & 76,5 & gemiddeld & sterk dalend \\
\hline MBO apothekersassistent & 82,5 & hoog & stijgend \\
\hline MBO sociaal-cultureel & 42 & gemiddeld & sterk stijgend \\
\hline MBO verzorging & 31 & gemiddeld & sterk dalend \\
\hline MBO uiterlijke verzorging & 23 & laag & sterk dalend \\
\hline MBO horeca & 43 & gemiddeld & sterk dalend \\
\hline HO natuur en techniek & 86 & hoog & stijgend \\
\hline HBO elektrotechniek & 93 & erg hoog & sterk stijgend \\
\hline $\mathrm{HBO}$ informatica & 87 & hoog & dalend \\
\hline WO wiskunde en natuurwetenschappen & 100 & erg hoog & constant \\
\hline HO economie & 76 & gemiddeld & stijgend \\
\hline HBO accountancy en bedrijfseconomie & 88 & hoog & - \\
\hline HBO commerciële economie & 71 & gemiddeld & constant \\
\hline HBO secretariaat & 85 & hoog & - \\
\hline HBO bedrijfskunde & 77 & hoog & stijgend \\
\hline WO econom(etr)ie & 95 & erg hoog & sterk stijgend \\
\hline WO bedrijfskunde & 74 & gemiddeld & - \\
\hline $\mathrm{HO}$ onderwijs en sociaal-cultureel & 54 & gemiddeld & dalend \\
\hline HO medisch & 79 & hoog & sterk stijgend \\
\hline \multicolumn{4}{|l|}{ Beroepen } \\
\hline Technische, ambachts- en industrieberoepen & 18 & laag & dalend \\
\hline Monteurs & 13 & laag & - \\
\hline Transportberoepen & 18 & laag & constant \\
\hline Laders en lossers & 22 & laag & constant \\
\hline Chauffeurs & 3 & erg laag & - \\
\hline Medische en paramedische beroepen & 71 & gemiddeld & - \\
\hline Apothekersassistenten en medisch laboranten & 71 & gemiddeld & constant \\
\hline Economisch-administratieve beroepen & 77 & hoog & stijgend \\
\hline Productieplanners & 82 & hoog & sterk stijgend \\
\hline Organisatie-adviseurs & 86 & hoog & sterk stijgend \\
\hline Receptionisten en administratieve employés & 82 & hoog & constant \\
\hline Boekhouders en secretaresses & 90 & hoog & constant \\
\hline Assistent accountants & 93 & erg hoog & constant \\
\hline Accountants & 100 & erg hoog & constant \\
\hline Commercieel employés & 72 & gemiddeld & stijgend \\
\hline
\end{tabular}




\section{Handel}

Tabel 8.6 (vervolg)

Percentage werkenden dat regelmatig beeldschermwerk verricht, gemiddelde 2001-2002

\begin{tabular}{|c|c|c|c|}
\hline & $\%$ & typering & trend $2000-2002$ \\
\hline Commercieel medewerkers & 78 & hoog & sterk stijgend \\
\hline Technisch-commercieel employés & 60 & gemiddeld & sterk stijgend \\
\hline Leidinggevenden & 45 & gemiddeld & constant \\
\hline Informatica beroepen & 97 & erg hoog & constant \\
\hline Programmeurs & 100 & erg hoog & constant \\
\hline Systeemanalisten & 97 & erg hoog & constant \\
\hline Verzorgende en dienstverlenende beroepen & 20 & laag & stijgend \\
\hline Vakkenvullers & 19 & laag & sterk stijgend \\
\hline Verkopers & 17 & laag & - \\
\hline Winkeliers & 35 & gemiddeld & constant \\
\hline \multicolumn{4}{|l|}{ Specifieke groepen werkenden } \\
\hline Vrouwen & 42 & gemiddeld & stijgend \\
\hline Jongeren & 33 & gemiddeld & constant \\
\hline Ouderen & 38 & gemiddeld & stijgend \\
\hline Allochtonen & 26 & gemiddeld & sterk dalend \\
\hline Totaal & 40 & gemiddeld & stijgend \\
\hline
\end{tabular}

Bron: ROA/CBS 
Tabel 8.7

Percentage werkenden dat deelneemt aan scholingstrajecten korter dan 6 maanden, gemiddelde 2001-2002

\begin{tabular}{|c|c|c|c|}
\hline & $\%$ & typering & trend $2000-2002$ \\
\hline \multicolumn{4}{|l|}{ Opleidingen } \\
\hline Basisonderwijs & 2 & laag & sterk dalend \\
\hline VMBO theorie & 2 & laag & - \\
\hline VMBO natuur en techniek & 3 & laag & - \\
\hline VMBO economie & 1 & erg laag & sterk dalend \\
\hline VMBO administratie, handel en mode & 1 & erg laag & sterk dalend \\
\hline VMBO verzorging & 2 & laag & sterk dalend \\
\hline VMBO (uiterlijke) verzorging & 2 & laag & sterk dalend \\
\hline HAVO/VWO & 2 & laag & sterk dalend \\
\hline MBO natuur en techniek & 5 & gemiddeld & constant \\
\hline MBO motorvoertuigentechniek & 6 & hoog & - \\
\hline MBO elektrotechniek & 5 & gemiddeld & dalend \\
\hline MBO economie & 3 & laag & - \\
\hline MBO administratie & 3 & laag & sterk stijgend \\
\hline MBO handel & 3 & laag & - \\
\hline MBO dienstverlening en gezondheidszorg & 5 & gemiddeld & constant \\
\hline HO natuur en techniek & 6 & hoog & sterk dalend \\
\hline HO economie & 4 & gemiddeld & sterk dalend \\
\hline HBO bedrijfskunde & 4 & gemiddeld & sterk dalend \\
\hline HO onderwijs en sociaal-cultureel & 4 & gemiddeld & sterk dalend \\
\hline \multicolumn{4}{|l|}{ Beroepen } \\
\hline Technische, ambachts- en industrieberoepen & 4 & gemiddeld & sterk stijgend \\
\hline Monteurs & 6 & hoog & sterk stijgend \\
\hline Transportberoepen & 2 & laag & - \\
\hline Laders en lossers & 2 & laag & - \\
\hline Chauffeurs & 1 & erg laag & - \\
\hline Medische en paramedische beroepen & 7 & hoog & - \\
\hline Apothekersassistenten en medisch laboranten & 8 & erg hoog & - \\
\hline Economisch-administratieve beroepen & 3 & gemiddeld & dalend \\
\hline Receptionisten en administratieve employés & 2 & laag & - \\
\hline Boekhouders en secretaresses & 3 & laag & sterk stijgend \\
\hline Commercieel employés & 3 & laag & sterk dalend \\
\hline Commercieel medewerkers & 4 & gemiddeld & sterk stijgend \\
\hline Informatica beroepen & 9 & erg hoog & - \\
\hline Verzorgende en dienstverlenende beroepen & 2 & laag & sterk dalend \\
\hline Vakkenvullers & 2 & laag & sterk dalend \\
\hline Verkopers & 1 & erg laag & sterk dalend \\
\hline Winkeliers & 3 & laag & sterk dalend \\
\hline \multicolumn{4}{|l|}{ Specifieke groepen werkenden } \\
\hline Vrouwen & 3 & laag & constant \\
\hline Jongeren & 3 & laag & constant \\
\hline Ouderen & 3 & laag & sterk dalend \\
\hline Allochtonen & 1 & erg laag & - \\
\hline Totaal & 3 & laag & sterk dalend \\
\hline
\end{tabular}

Bron: ROA/CBS 


\section{Handel}

Tabel 8.8

Percentage werkenden dat deelneemt aan scholingstrajecten van 6 maanden of langer, gemiddelde 20012002

$\% \quad$ typering trend 2000-2002

Opleidingen

Basisonderwijs

VMBO theorie

VMBO natuur en techniek

VMBO voertuigentechniek

VMBO economie

VMBO administratie, handel en mode

VMBO verzorging

VMBO (uiterlijke) verzorging

HAVO/VWO

MBO natuur en techniek

MBO motorvoertuigentechniek

MBO elektrotechniek

$\mathrm{MBO}$ economie

MBO administratie

MBO handel

MBO dienstverlening en gezondheidszorg

$\mathrm{HO}$ natuur en techniek

$\mathrm{HO}$ economie

HBO bedrijfskunde

$\mathrm{HO}$ onderwijs en sociaal-cultureel

Beroepen

Technische, ambachts- en industrieberoepen

Assembleurs

Monteurs

Transportberoepen

Laders en lossers

Chauffeurs

Medische en paramedische beroepen

Apothekersassistenten en medisch laboranten

Economisch-administratieve beroepen

Receptionisten en administratieve employés

Boekhouders en secretaresses

Commercieel employés

Commercieel medewerkers

Informatica beroepen

Verzorgende en dienstverlenende beroepen

Vakkenvullers

Verkopers

Winkeliers

Specifieke groepen werkenden

Vrouwen

Jongeren

Ouderen

Allochtonen

Totaal

Bron: ROA/CBS hoog constant

erg hoog

gemiddeld constant

erg hoog sterk dalend

gemiddeld

gemiddeld

gemiddeld

gemiddeld

erg hoog

gemiddeld

gemiddeld

gemiddeld

gemiddeld

gemiddeld

gemiddeld

gemiddeld

gemiddeld

hoog

constant

constant

constant

sterk dalend

sterk stijgend

dalend

constant

dalend

sterk stijgend

sterk stijgend

erg hoog sterk stijgend

gemiddeld sterk stijgend

gemiddeld constant

erg hoog

gemiddeld

laag

sterk dalend

sterk dalend

gemiddeld sterk dalend

erg laag

gemiddeld

gemiddeld

gemiddeld

gemiddeld

gemiddeld

laag

gemiddeld

hoog

sterk stijgend

constant

dalend

erg hoog

erg hoog

erg hoog

hoog

sterk stijgend

-

$-$

hoog

$\begin{array}{rll}16 & \text { hoog } & \text { stijgend } \\ 33 & \text { erg hoog } & \text { stijgend } \\ 3 & \text { erg laag } & \text { sterk stijgend } \\ 21 & \text { erg hoog } & \text { constant } \\ & & \\ 16 & \text { hoog } & \text { constant }\end{array}$


Tabel 8.9

Doelgroepen voor het scholingsbeleid en risicofactoren

Doelgroepen

risicofactor(en)

Technisch-commercieel employés

krimpende werkgelegenheid 

9. Transport en communicatie 

Tabel 9.1

Kernindicatoren

\section{Arbeidsomstandigheden}

Belastende arbeidsomstandigheden

$\%$ werknemers dat regelmatig geconfronteerd wordt met:

$\begin{array}{rrl}2000 & 2001 / 2002 & \text { typering } \\ \% & \% & \\ 10 & 11 & \text { gemiddeld } \\ 6 & 7 & \text { gemiddeld } \\ 24 & 22 & \text { gemiddeld } \\ 37 & 35 & \text { gemiddeld } \\ 40 & 46 & \text { gemiddeld }\end{array}$

Lawaai

Trilling

Kracht zetten

Tijdsdruk

Beeldschermwerk

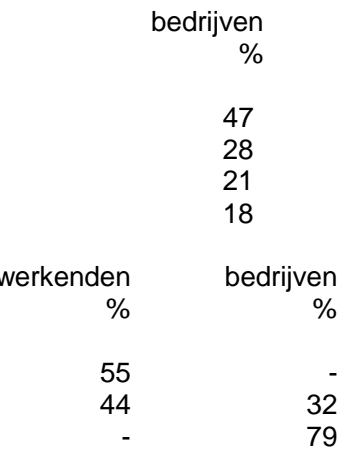

Vernieuwingen in het productieproces, 1999-2001

Automatisering, 2002

jaarlijks \%

Verschuivingen in de werkgelegenheid

Verwachte werkgelegenheidsontwikkeling, 2003-2008

$-1$

\section{Scholingsdeelname}

$\begin{array}{lrr} & 2000 \text { typering } \\ & 2001 / \text { \% } & \begin{array}{r}2002 \\ \%\end{array} \\ \text { Deelname aan opleidingstrajecten korter dan 6 maanden (momentopname) } & 6 & 4 \text { gemiddeld } \\ \text { Deelname aan opleidingstrajecten van 6 maanden of langer (momentopname) } & 9 & 9 \text { laag }\end{array}$

Bron: ROA/CBS/OSA 


\section{Risicoprofiel}

Figuur 9.1

Sectoraal risicoprofiel

\section{Transport en communicatie}

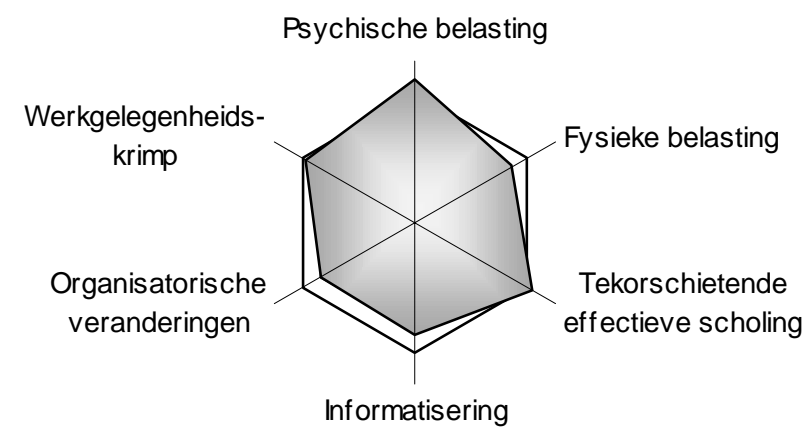

Tabel 92

Percentage werkenden dat regelmatig wordt geconfronteerd met lawaai tijdens het werk, gemiddelde 20012002

$\% \quad$ typering trend $2000-2002$

Opleidingen

Basisonderwijs

VMBO theorie

VMBO natuur en techniek

VMBO transport en logistiek

VMBO economie

VMBO consumptief en levensmiddelentechniek

HAVO/VWO

MBO natuur en techniek

$M B O$ vervoer en logistiek

$\mathrm{MBO}$ economie

$\mathrm{HO}$ natuur en techniek

HBO vervoer en logistiek

$\mathrm{HO}$ economie

Beroepen

Technische, ambachts- en industrieberoepen

Monteurs

Transportberoepen

Laders en lossers

Chauffeurs

Vliegers, scheepskapiteins en leidinggevenden transport

Stewards

Economisch-administratieve beroepen

gemiddeld -

gemiddeld sterk stijgend

hoog sterk stijgend

hoog

hoog sterk stijgend

erg hoog sterk stijgend

gemiddeld sterk dalend

hoog

hoog sterk stijgend

gemiddeld

hoog

erg hoog

laag

$\begin{array}{rll}26 & \text { hoog } & \text { dalend } \\ 33 & \text { erg hoog } & \text { constant } \\ 13 & \text { hoog } & \text { sterk stijgend } \\ 27 & \text { hoog } & \text { sterk stijgend } \\ 8 & \text { gemiddeld } & - \\ 41 & \text { erg hoog } & - \\ 41 & \text { erg hoog } & - \\ 5 & \text { gemiddeld } & \text { constant }\end{array}$


Tabel 9.2 (vervolg)

Percentage werkenden dat regelmatig wordt geconfronteerd met lawaai tijdens het werk, gemiddelde 20012002

\begin{tabular}{|c|c|c|c|}
\hline & $\%$ & typering & trend 2000-2002 \\
\hline $\begin{array}{l}\text { Receptionisten en administratieve employés } \\
\text { Boekhouders en secretaresses } \\
\text { Commercieel employés }\end{array}$ & $\begin{array}{l}4 \\
8 \\
3\end{array}$ & $\begin{array}{l}\text { gemiddeld } \\
\text { gemiddeld } \\
\text { laag }\end{array}$ & $\begin{array}{l}\text { sterk dalend } \\
\text { - } \\
\text { sterk dalend }\end{array}$ \\
\hline $\begin{array}{l}\text { Specifieke groepen werkenden } \\
\text { Vrouwen } \\
\text { Jongeren } \\
\text { Ouderen } \\
\text { Allochtonen }\end{array}$ & $\begin{array}{r}8 \\
9 \\
8 \\
20\end{array}$ & $\begin{array}{l}\text { gemiddeld } \\
\text { gemiddeld } \\
\text { gemiddeld } \\
\text { hoog }\end{array}$ & $\begin{array}{l}\text { sterk stijgend } \\
\text { sterk stijgend } \\
\text { sterk stijgend }\end{array}$ \\
\hline Totaal & 11 & gemiddeld & stijgend \\
\hline
\end{tabular}

Bron: ROA/CBS

Tabel 9.3

Percentage werkenden dat regelmatig werkt met trillende apparaten, gemiddelde 2001-2002

\begin{tabular}{|c|c|c|c|}
\hline & $\%$ & typering & trend $2000-2002$ \\
\hline \multicolumn{4}{|l|}{ Opleidingen } \\
\hline Basisonderwijs & 6 & gemiddeld & sterk stijgend \\
\hline VMBO theorie & 5 & gemiddeld & - \\
\hline VMBO natuur en techniek & 11 & gemiddeld & - \\
\hline VMBO transport en logistiek & 13 & hoog & sterk stijgend \\
\hline HAVO/VWO & 6 & gemiddeld & stijgend \\
\hline MBO natuur en techniek & 13 & hoog & constant \\
\hline MBO vervoer en logistiek & 14 & hoog & sterk stijgend \\
\hline MBO economie & 3 & gemiddeld & sterk stijgend \\
\hline $\mathrm{HO}$ natuur en techniek & 11 & gemiddeld & sterk stijgend \\
\hline $\mathrm{HO}$ economie & 1 & laag & - \\
\hline \multicolumn{4}{|l|}{ Beroepen } \\
\hline Technische, ambachts- en industrieberoepen & 24 & hoog & constant \\
\hline Monteurs & 38 & erg hoog & sterk stijgend \\
\hline Transportberoepen & 8 & gemiddeld & sterk stijgend \\
\hline Laders en lossers & 9 & gemiddeld & sterk stijgend \\
\hline Chauffeurs & 8 & gemiddeld & sterk stijgend \\
\hline Economisch-administratieve beroepen & 1 & laag & - \\
\hline Receptionisten en administratieve employés & 1 & laag & constant \\
\hline Boekhouders en secretaresses & 4 & gemiddeld & sterk stijgend \\
\hline Commercieel employés & 1 & laag & sterk stijgend \\
\hline \multicolumn{4}{|l|}{ Specifieke groepen werkenden } \\
\hline Vrouwen & 1 & laag & - \\
\hline Jongeren & 7 & gemiddeld & - \\
\hline Ouderen & 4 & gemiddeld & - \\
\hline Allochtonen & 9 & gemiddeld & sterk stijgend \\
\hline Totaal & 7 & gemiddeld & sterk stijgend \\
\hline
\end{tabular}

Bron: ROA/CBS 


\section{Transport en communicatie}

Tabel 9.4

Percentage werkenden dat regelmatig kracht moet zetten tijdens het werk, gemiddelde 2001-2002

\begin{tabular}{|c|c|c|c|}
\hline & $\%$ & typering & trend $2000-2002$ \\
\hline \multicolumn{4}{|l|}{ Opleidingen } \\
\hline Basisonderwijs & 37 & hoog & - \\
\hline VMBO theorie & 23 & gemiddeld & sterk dalend \\
\hline VMBO natuur en techniek & 38 & hoog & constant \\
\hline VMBO bouwtechniek & 46 & hoog & sterk stijgend \\
\hline VMBO metaal: mechanische techniek & 47 & erg hoog & - \\
\hline VMBO transport en logistiek & 33 & hoog & - \\
\hline VMBO economie & 35 & hoog & sterk stijgend \\
\hline VMBO consumptief en levensmiddelentechniek & 62 & erg hoog & sterk stijgend \\
\hline HAVO/VWO & 19 & gemiddeld & sterk stijgend \\
\hline MBO natuur en techniek & 24 & gemiddeld & - \\
\hline MBO motorvoertuigentechniek & 54 & erg hoog & stijgend \\
\hline MBO vervoer en logistiek & 20 & gemiddeld & sterk dalend \\
\hline MBO economie & 8 & gemiddeld & - \\
\hline MBO dienstverlening en gezondheidszorg & 24 & gemiddeld & stijgend \\
\hline $\mathrm{HO}$ natuur en techniek & 10 & gemiddeld & constant \\
\hline $\mathrm{HO}$ economie & 1 & laag & - \\
\hline \multicolumn{4}{|l|}{ Beroepen } \\
\hline Technische, ambachts- en industrieberoepen & 28 & gemiddeld & constant \\
\hline Productiemedewerkers & 61 & erg hoog & sterk stijgend \\
\hline Monteurs & 29 & gemiddeld & constant \\
\hline Transportberoepen & 38 & hoog & constant \\
\hline Laders en lossers & 68 & erg hoog & stijgend \\
\hline Chauffeurs & 36 & hoog & dalend \\
\hline Schippers en conducteurs & 27 & gemiddeld & - \\
\hline Stewards & 48 & erg hoog & - \\
\hline Economisch-administratieve beroepen & 5 & gemiddeld & - \\
\hline Receptionisten en administratieve employés & 8 & gemiddeld & - \\
\hline Boekhouders en secretaresses & 3 & laag & - \\
\hline Commercieel employés & 8 & gemiddeld & sterk stijgend \\
\hline \multicolumn{4}{|l|}{ Specifieke groepen werkenden } \\
\hline Vrouwen & 12 & gemiddeld & - \\
\hline Jongeren & 25 & gemiddeld & dalend \\
\hline Ouderen & 19 & gemiddeld & stijgend \\
\hline Allochtonen & 22 & gemiddeld & - \\
\hline Totaal & 22 & gemiddeld & constant \\
\hline
\end{tabular}

Bron: ROA/CBS 
Tabel 9.5

Percentage werkenden dat regelmatig onder hoge tijdsdruk werkt, gemiddelde 2001-2002

\begin{tabular}{|c|c|c|c|}
\hline & $\%$ & typering & trend $2000-2002$ \\
\hline \multicolumn{4}{|l|}{ Opleidingen } \\
\hline Basisonderwijs & 29 & gemiddeld & sterk dalend \\
\hline VMBO theorie & 32 & gemiddeld & - \\
\hline VMBO natuur en techniek & 36 & gemiddeld & constant \\
\hline VMBO bouwtechniek & 33 & gemiddeld & sterk dalend \\
\hline VMBO metaal: mechanische techniek & 44 & erg hoog & sterk stijgend \\
\hline VMBO transport en logistiek & 36 & gemiddeld & constant \\
\hline VMBO economie & 34 & gemiddeld & sterk dalend \\
\hline VMBO administratie, handel en mode & 32 & gemiddeld & sterk dalend \\
\hline HAVO/VWO & 34 & gemiddeld & constant \\
\hline MBO natuur en techniek & 39 & hoog & constant \\
\hline MBO elektrotechniek & 34 & gemiddeld & - \\
\hline MBO vervoer en logistiek & 45 & erg hoog & constant \\
\hline MBO openbare orde en veiligheid & 45 & erg hoog & dalend \\
\hline MBO economie & 35 & gemiddeld & constant \\
\hline MBO administratie & 36 & gemiddeld & constant \\
\hline MBO handel & 27 & gemiddeld & - \\
\hline MBO toerisme en recreatie & 33 & gemiddeld & constant \\
\hline MBO dienstverlening en gezondheidszorg & 28 & gemiddeld & - \\
\hline HO natuur en techniek & 40 & hoog & constant \\
\hline HBO vervoer en logistiek & 42 & hoog & - \\
\hline $\mathrm{HO}$ economie & 42 & hoog & dalend \\
\hline $\mathrm{HO}$ onderwijs en sociaal-cultureel & 38 & gemiddeld & dalend \\
\hline \multicolumn{4}{|l|}{ Beroepen } \\
\hline Technische, ambachts- en industrieberoepen & 34 & gemiddeld & dalend \\
\hline Productiemedewerkers & 37 & gemiddeld & \\
\hline Monteurs & 39 & hoog & constant \\
\hline Transportberoepen & 34 & gemiddeld & dalend \\
\hline Laders en lossers & 21 & laag & constant \\
\hline Chauffeurs & 34 & gemiddeld & dalend \\
\hline Schippers en conducteurs & 40 & hoog & sterk stijgend \\
\hline Vliegers, scheepskapiteins en leidinggevenden transport & 48 & erg hoog & sterk stijgend \\
\hline Stewards & 43 & hoog & - \\
\hline Economisch-administratieve beroepen & 39 & hoog & constant \\
\hline Productieplanners & 53 & erg hoog & - \\
\hline Receptionisten en administratieve employés & 29 & gemiddeld & sterk stijgend \\
\hline Boekhouders en secretaresses & 31 & gemiddeld & - \\
\hline Commercieel employés & 35 & gemiddeld & sterk stijgend \\
\hline Commercieel medewerkers & 38 & gemiddeld & - \\
\hline Administratieve transportemployés & 42 & hoog & sterk dalend \\
\hline Managers & 56 & erg hoog & dalend \\
\hline Informatica beroepen & 35 & gemiddeld & sterk dalend \\
\hline \multicolumn{4}{|l|}{ Specifieke groepen werkenden } \\
\hline Vrouwen & 33 & gemiddeld & dalend \\
\hline Jongeren & 26 & gemiddeld & \\
\hline Ouderen & 36 & gemiddeld & dalend \\
\hline Allochtonen & 31 & gemiddeld & dalend \\
\hline Totaal & 35 & gemiddeld & dalend \\
\hline
\end{tabular}

Bron: ROA/CBS 


\section{Transport en communicatie}

Tabel 9.6

Percentage werkenden dat regelmatig beeldschermwerk verricht, gemiddelde 2001-2002

\begin{tabular}{|c|c|c|c|}
\hline & $\%$ & typering & trend 2000-2002 \\
\hline \multicolumn{4}{|l|}{ Opleidingen } \\
\hline Basisonderwijs & 12 & laag & - \\
\hline VMBO theorie & 38 & gemiddeld & - \\
\hline VMBO natuur en techniek & 15 & laag & sterk stijgend \\
\hline VMBO elektrotechniek & 45 & gemiddeld & - \\
\hline VMBO transport en logistiek & 4 & erg laag & - \\
\hline VMBO economie & 39 & gemiddeld & constant \\
\hline VMBO administratie, handel en mode & 55 & gemiddeld & - \\
\hline HAVO/VWO & 62 & gemiddeld & stijgend \\
\hline MBO natuur en techniek & 41 & gemiddeld & - \\
\hline MBO elektrotechniek & 70 & gemiddeld & sterk dalend \\
\hline MBO vervoer en logistiek & 46 & gemiddeld & stijgend \\
\hline MBO economie & 68 & gemiddeld & constant \\
\hline MBO administratie & 76 & gemiddeld & constant \\
\hline MBO handel & 52 & gemiddeld & sterk stijgend \\
\hline MBO secretariaat & 80 & hoog & sterk dalend \\
\hline MBO toerisme en recreatie & 89 & hoog & - \\
\hline MBO dienstverlening en gezondheidszorg & 50 & gemiddeld & sterk stijgend \\
\hline MBO horeca & 55 & gemiddeld & constant \\
\hline HO natuur en techniek & 76 & gemiddeld & stijgend \\
\hline HBO elektrotechniek & 98 & erg hoog & constant \\
\hline HBO informatica & 97 & erg hoog & dalend \\
\hline HBO vervoer en logistiek & 69 & gemiddeld & - \\
\hline $\mathrm{HO}$ economie & 91 & erg hoog & sterk stijgend \\
\hline HBO accountancy en bedrijfseconomie & 82 & hoog & - \\
\hline HBO commerciële economie & 93 & erg hoog & - \\
\hline HBO toerisme en recreatie & 100 & erg hoog & sterk stijgend \\
\hline HBO bedrijfskunde & 85 & hoog & sterk stijgend \\
\hline HO onderwijs en sociaal-cultureel & 58 & gemiddeld & sterk stijgend \\
\hline \multicolumn{4}{|l|}{ Beroepen } \\
\hline Technische, ambachts- en industrieberoepen & 46 & gemiddeld & sterk stijgend \\
\hline Monteurs & 23 & laag & sterk stijgend \\
\hline Elektromonteurs & 88 & hoog & sterk stijgend \\
\hline Transportberoepen & 9 & laag & - \\
\hline Laders en lossers & 14 & laag & sterk dalend \\
\hline Chauffeurs & 2 & erg laag & sterk stijgend \\
\hline Schippers en conducteurs & 35 & gemiddeld & - \\
\hline Vliegers, scheepskapiteins en leidinggevenden transport & 61 & gemiddeld & - \\
\hline Economisch-administratieve beroepen & 86 & hoog & constant \\
\hline Productieplanners & 90 & hoog & stijgend \\
\hline Organisatie-adviseurs & 85 & hoog & - \\
\hline Receptionisten en administratieve employés & 78 & hoog & constant \\
\hline Boekhouders en secretaresses & 93 & erg hoog & dalend \\
\hline Assistent accountants & 94 & erg hoog & dalend \\
\hline Commercieel employés & 87 & hoog & dalend \\
\hline Commercieel medewerkers & 92 & erg hoog & stijgend \\
\hline Administratieve transportemployés & 81 & hoog & - \\
\hline Informatica beroepen & 97 & erg hoog & constant \\
\hline Programmeurs & 96 & erg hoog & constant \\
\hline Systeemanalisten & 97 & erg hoog & constant \\
\hline
\end{tabular}


Tabel 9.6 (vervolg)

Percentage werkenden dat regelmatig beeldschermwerk verricht, gemiddelde 2001-2002

\begin{tabular}{lllll}
\hline & $\%$ & typering & trend 2000-2002 \\
\hline $\begin{array}{l}\text { Specifieke groepen werkenden } \\
\text { Vrouwen }\end{array}$ & 69 & gemiddeld & \\
Jongeren & 51 & gemiddeld & stijgend \\
Ouderen & 33 & gemiddeld & constant \\
Allochtonen & 47 & gemiddeld & sterk stijgend \\
Totaal & 46 & gemiddeld & - \\
\hline
\end{tabular}

Bron: ROA/CBS

Tabel 9.7

Percentage werkenden dat deelneemt aan scholingstrajecten korter dan 6 maanden, gemiddelde 2001-2002

$\% \quad$ typering trend 2000-2002

Opleidingen

Basisonderwijs

VMBO theorie

VMBO natuur en techniek

VMBO transport en logistiek

HAVO/VWO

MBO natuur en techniek

$M B O$ vervoer en logistiek

MBO economie

$\mathrm{HO}$ natuur en techniek

$\mathrm{HO}$ economie

(20)

Beroepen

Technische, ambachts- en industrieberoepen

Monteurs

Transportberoepen

Laders en lossers

Chauffeurs

Economisch-administratieve beroepen

Receptionisten en administratieve employés

Boekhouders en secretaresses

Commercieel employés

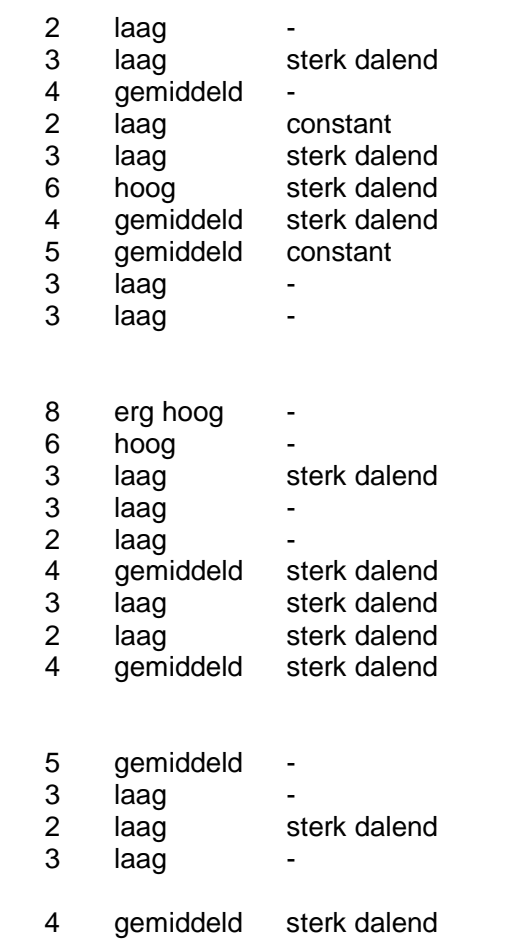

Specifieke groepen werkenden

Vrouwen

Jongeren

Ouderen

Allochtonen

Totaal

Bron: ROA/CBS 


\section{Transport en communicatie}

Tabel 9.8

Percentage werkenden dat deelneemt aan scholingstrajecten van 6 maanden of langer, gemiddelde 20012002

$\% \quad$ typering trend 2000-2002

Opleidingen

Basisonderwijs

VMBO theorie

VMBO natuur en techniek

VMBO transport en logistiek

HAVO/VWO

MBO natuur en techniek

$M B O$ vervoer en logistiek

MBO economie

$\mathrm{HO}$ natuur en techniek

$\mathrm{HO}$ economie

\section{erg laag}

gemiddeld constan

erg laag sterk dalend

erg laag sterk stijgend

erg hoog

erg laag

erg laag

gemiddeld

laag

12 gemiddeld -

sterk dalend

Beroepen

Technische, ambachts- en industrieberoepen

Monteurs

Transportberoepen

Laders en lossers

Chauffeurs

Economisch-administratieve beroepen

Receptionisten en administratieve employés

Boekhouders en secretaresses

Commercieel employés

$9 \quad$ laag

9 laag

7 laag

19 hoog

5 erg laag

gemiddeld

gemiddeld

gemiddeld

10 gemiddeld constant

constant

constant

constant

dalend

Specifieke groepen werkenden

Vrouwen

Jongeren

Ouderen

Allochtonen

9 laag

20 hoog

1 erg laag

14 gemiddeld

Totaal constant

constant

$9 \quad$ laag

constant

Bron: ROA/CBS

Tabel 9.9

Doelgroepen voor het scholingsbeleid en risicofactoren

Doelgroepen

risicofactor(en)

Vliegers, scheepskapiteins en leidinggevenden in het transport

tijdsdruk

Vliegers, scheepskapiteins
Schippers en conducteurs

krimpende werkgelegenheid 
10. Bank en verzekering 

Tabel 10.1

Kernindicatoren

\section{Arbeidsomstandigheden}

Belastende arbeidsomstandigheden

$\%$ werknemers dat regelmatig geconfronteerd wordt met:

$\begin{array}{rrl}2000 & 2001 / 2002 & \text { typering } \\ \% & \% & \\ 2 & 1 & \text { erg laag } \\ 1 & 0 & \text { erg laag } \\ 2 & 2 & \text { laag } \\ 32 & 32 & \text { gemiddeld } \\ 93 & 90 & \text { hoog }\end{array}$

Lawaai

Trilling

Kracht zetten

Tijdsdruk

Beeldschermwerk

Technologische en organisatorische ontwikkelingen

Organisatorische ontwikkelingen

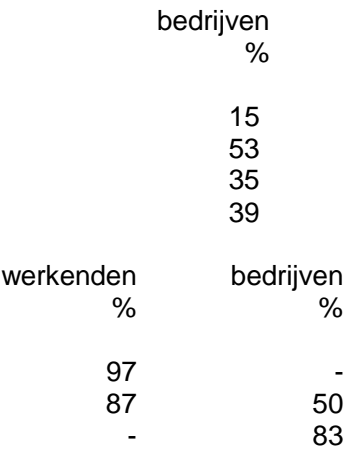

Vernieuwingen in het productieproces, 1999-2001

Automatisering, 2002

jaarlijks \%

Kleine productverandering, 2000-2002

Ingrijpende productverandering, 2000-2002

Veranderingen in positie, 2000-2002

Interne reorganisaties, 2000-2002

Technologische vernieuwingen

Verschuivingen in de werkgelegenheid

Verwachte werkgelegenheidsontwikkeling, 2003-2008

\section{Scholingsdeelname}

\begin{tabular}{|c|c|c|c|}
\hline (2) & $\begin{array}{r}2000 \\
\%\end{array}$ & $\begin{array}{r}2001 / \\
2002 \\
\%\end{array}$ & typering \\
\hline Deelname aan opleidingstrajecten korter dan 6 maanden (momentopname) & 11 & 10 & erg hoog \\
\hline Deelname aan opleidingstrajecten van 6 maanden of langer (momentopname) & 17 & 16 & hoog \\
\hline
\end{tabular}

Bron: ROA/CBS/OSA 


\section{Risicoprofiel}

Figuur 10.1

Sectoraal risicoprofiel

\section{Bank en verzekering}

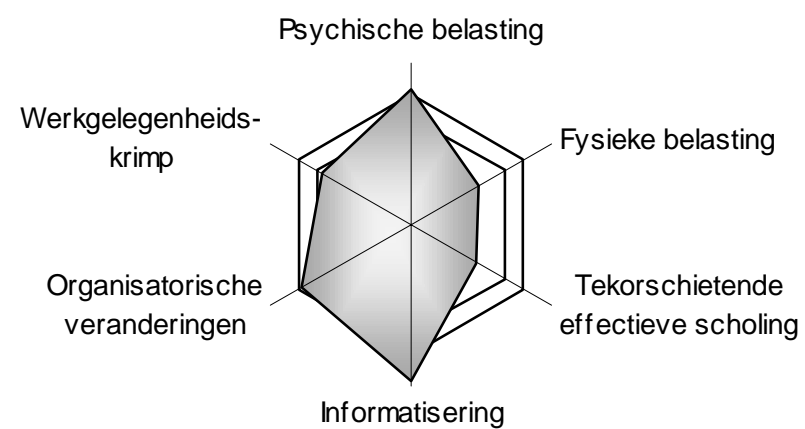

Tabel 10.2

Percentage werkenden dat regelmatig wordt geconfronteerd met lawaai tijdens het werk, gemiddelde 20012002

$\% \quad$ typering trend 2000-2002

Opleidingen
VMBO theorie
HAVO/VWO
MBO economie
MBO administratie
HO natuur en techniek
HO economie
HBO commerciële economie

Beroepen

Economisch-administratieve beroepen

Receptionisten en administratieve employés

Boekhouders en secretaresses

Commercieel employés

Commercieel medewerkers

Informatica beroepen

Specifieke groepen werkenden

Vrouwen

Jongeren

Ouderen

Allochtonen

Totaal

Bron: ROA/CBS
6 gemiddeld sterk stijgend

0 erg laag constant

1 erg laag sterk dalend

1 erg laag sterk dalend

1 erg laag constant

1 erg laag sterk stijgend

1 erg laag sterk stijgend

$\begin{array}{lll}1 & \text { laag } & \text { sterk dalend } \\ 1 & \text { erg laag } & - \\ 0 & \text { erg laag } & \text { sterk dalend } \\ 2 & \text { laag } & - \\ 1 & \text { erg laag } & \text { sterk dalend } \\ 2 & \text { laag } & -\end{array}$

$\begin{array}{lll}1 & \text { erg laag } & - \\ 2 & \text { laag } & - \\ 3 & \text { laag } & \text { sterk dalend } \\ - & - & - \\ & & \\ 1 & \text { erg laag } & \text { constant }\end{array}$


Tabel 10.3

Percentage werkenden dat regelmatig werkt met trillende apparaten, gemiddelde 2001-2002

\begin{tabular}{|c|c|c|c|}
\hline & $\%$ & typering & trend $2000-2002$ \\
\hline \multicolumn{4}{|l|}{ Opleidingen } \\
\hline HO natuur en techniek & 1 & laag & sterk stijgend \\
\hline \multicolumn{4}{|l|}{ Beroepen } \\
\hline Economisch-administratieve beroepen & 0 & erg laag & sterk stijgend \\
\hline Receptionisten en administratieve employés & 1 & laag & constant \\
\hline Boekhouders en secretaresses & 0 & erg laag & sterk dalend \\
\hline Informatica beroepen & 0 & erg laag & sterk dalend \\
\hline \multicolumn{4}{|l|}{ Specifieke groepen werkenden } \\
\hline Vrouwen & 0 & erg laag & sterk stijgend \\
\hline Jongeren & - & - & \\
\hline Ouderen & 0 & erg laag & sterk dalend \\
\hline Allochtonen & - & - & - \\
\hline Totaal & 0 & erg laag & sterk dalend \\
\hline
\end{tabular}

Bron: ROA/CBS

Tabel 10.4

Percentage werkenden dat regelmatig kracht moet zetten tijdens het werk, gemiddelde 2001-2002

\begin{tabular}{|c|c|c|c|}
\hline & $\%$ & typering & trend $2000-2002$ \\
\hline \multicolumn{4}{|l|}{ Opleidingen } \\
\hline VMBO theorie & 2 & laag & sterk stijgend \\
\hline HAVO/VWO & 2 & laag & - \\
\hline MBO economie & 2 & laag & - \\
\hline MBO administratie & 0 & erg laag & - \\
\hline HO natuur en techniek & 1 & laag & sterk stijgend \\
\hline $\mathrm{HO}$ economie & 0 & erg laag & sterk dalend \\
\hline \multicolumn{4}{|l|}{ Beroepen } \\
\hline Economisch-administratieve beroepen & 1 & laag & sterk dalend \\
\hline Receptionisten en administratieve employés & 1 & laag & sterk dalend \\
\hline Boekhouders en secretaresses & 3 & laag & sterk stijgend \\
\hline Commercieel employés & 1 & laag & sterk dalend \\
\hline Commercieel medewerkers & 1 & laag & stijgend \\
\hline Informatica beroepen & 3 & laag & - \\
\hline \multicolumn{4}{|l|}{ Specifieke groepen werkenden } \\
\hline Vrouwen & 2 & laag & sterk stijgend \\
\hline Jongeren & 2 & laag & - \\
\hline Ouderen & 4 & gemiddeld & - \\
\hline Allochtonen & 4 & gemiddeld & - \\
\hline Totaal & 2 & laag & - \\
\hline
\end{tabular}

Bron: ROA/CBS 


\section{Bank en verzekering}

Tabel 10.5

Percentage werkenden dat regelmatig onder hoge tijdsdruk werkt, gemiddelde 2001-2002

\begin{tabular}{|c|c|c|c|}
\hline & $\%$ & typering & trend $2000-2002$ \\
\hline \multicolumn{4}{|l|}{ Opleidingen } \\
\hline VMBO theorie & 24 & laag & stijgend \\
\hline HAVO/VWO & 35 & gemiddeld & sterk stijgend \\
\hline MBO economie & 28 & gemiddeld & constant \\
\hline MBO administratie & 25 & laag & sterk dalend \\
\hline MBO secretariaat & 33 & gemiddeld & sterk stijgend \\
\hline $\mathrm{HO}$ natuur en techniek & 40 & hoog & sterk dalend \\
\hline HBO informatica & 43 & hoog & sterk dalend \\
\hline $\mathrm{HO}$ economie & 38 & gemiddeld & constant \\
\hline HBO accountancy en bedrijfseconomie & 35 & gemiddeld & constant \\
\hline HBO commerciële economie & 34 & gemiddeld & - \\
\hline HBO bedrijfskunde & 35 & gemiddeld & - \\
\hline WO econom(etr)ie & 39 & hoog & sterk dalend \\
\hline WO rechten en bestuurskunde & 54 & erg hoog & stijgend \\
\hline HO onderwijs en sociaal-cultureel & 33 & gemiddeld & - \\
\hline \multicolumn{4}{|l|}{ Beroepen } \\
\hline Economisch-administratieve beroepen & 32 & gemiddeld & constant \\
\hline Receptionisten en administratieve employés & 25 & laag & constant \\
\hline Boekhouders en secretaresses & 27 & gemiddeld & constant \\
\hline Assistent accountants & 43 & hoog & sterk stijgend \\
\hline Commercieel employés & 30 & gemiddeld & stijgend \\
\hline Commercieel medewerkers & 35 & gemiddeld & - \\
\hline Juristen & 62 & erg hoog & dalend \\
\hline Informatica beroepen & 34 & gemiddeld & sterk dalend \\
\hline Systeemanalisten & 35 & gemiddeld & sterk dalend \\
\hline \multicolumn{4}{|l|}{ Specifieke groepen werkenden } \\
\hline Vrouwen & 27 & gemiddeld & constant \\
\hline Jongeren & 25 & laag & - \\
\hline Ouderen & 37 & gemiddeld & constant \\
\hline Allochtonen & 33 & gemiddeld & constant \\
\hline Totaal & 32 & gemiddeld & constant \\
\hline
\end{tabular}

Bron: ROA/CBS 
Tabel 10.6

Percentage werkenden dat regelmatig beeldschermwerk verricht, gemiddelde 2001-2002

\begin{tabular}{|c|c|c|c|}
\hline & $\%$ & typering & trend $2000-2002$ \\
\hline \multicolumn{4}{|l|}{ Opleidingen } \\
\hline Basisonderwijs & 85 & hoog & constant \\
\hline VMBO theorie & 91 & erg hoog & constant \\
\hline VMBO economie & 97 & erg hoog & constant \\
\hline VMBO administratie, handel en mode & 97 & erg hoog & constant \\
\hline HAVO/VWO & 94 & erg hoog & constant \\
\hline MBO natuur en techniek & 80 & hoog & sterk dalend \\
\hline MBO automatisering & 100 & erg hoog & constant \\
\hline MBO economie & 94 & erg hoog & constant \\
\hline MBO administratie & 94 & erg hoog & constant \\
\hline MBO handel & 91 & erg hoog & dalend \\
\hline MBO secretariaat & 97 & erg hoog & constant \\
\hline MBO dienstverlening en gezondheidszorg & 80 & hoog & dalend \\
\hline MBO verzorging & 80 & hoog & - \\
\hline MBO geld, bank en belastingen & 97 & erg hoog & stijgend \\
\hline MBO verzekeringswezen & 91 & erg hoog & dalend \\
\hline HO natuur en techniek & 86 & hoog & sterk dalend \\
\hline HBO informatica & 97 & erg hoog & constant \\
\hline WO wiskunde en natuurwetenschappen & 100 & erg hoog & constant \\
\hline HO economie & 88 & hoog & dalend \\
\hline HBO accountancy en bedrijfseconomie & 99 & erg hoog & constant \\
\hline HBO commerciële economie & 90 & hoog & constant \\
\hline HBO bedrijfskunde & 85 & hoog & dalend \\
\hline WO econom(etr)ie & 85 & hoog & dalend \\
\hline WO bedrijfskunde & 88 & hoog & sterk dalend \\
\hline WO rechten en bestuurskunde & 84 & hoog & - \\
\hline $\mathrm{HO}$ onderwijs en sociaal-cultureel & 96 & erg hoog & constant \\
\hline \multicolumn{4}{|l|}{ Beroepen } \\
\hline Economisch-administratieve beroepen & 90 & hoog & constant \\
\hline Receptionisten en administratieve employés & 93 & erg hoog & constant \\
\hline Boekhouders en secretaresses & 95 & erg hoog & constant \\
\hline Assistent accountants & 93 & erg hoog & dalend \\
\hline Accountants & 93 & erg hoog & - \\
\hline Verzekeringsagenten & 100 & erg hoog & constant \\
\hline Commercieel employés & 90 & hoog & constant \\
\hline Commercieel medewerkers & 89 & hoog & constant \\
\hline Juristen & 100 & erg hoog & constant \\
\hline Managers & 73 & gemiddeld & constant \\
\hline Informatica beroepen & 94 & erg hoog & constant \\
\hline Programmeurs & 96 & erg hoog & constant \\
\hline Systeemanalisten & 92 & erg hoog & constant \\
\hline Informatici & 97 & erg hoog & constant \\
\hline \multicolumn{4}{|l|}{ Specifieke groepen werkenden } \\
\hline Vrouwen & 93 & erg hoog & dalend \\
\hline Jongeren & 91 & erg hoog & dalend \\
\hline Ouderen & 86 & hoog & constant \\
\hline Allochtonen & 92 & erg hoog & dalend \\
\hline Totaal & 90 & hoog & constant \\
\hline
\end{tabular}

Bron: ROA/CBS 


\section{Bank en verzekering}

Tabel 10.7

Percentage werkenden dat deelneemt aan scholingstrajecten korter dan 6 maanden, gemiddelde 2001-2002

\begin{tabular}{|c|c|c|c|}
\hline & $\%$ & typering & trend $2000-2002$ \\
\hline \multicolumn{4}{|l|}{ Opleidingen } \\
\hline VMBO theorie & 7 & hoog & - \\
\hline HAVO/VWO & 11 & erg hoog & constant \\
\hline MBO economie & 10 & erg hoog & dalend \\
\hline MBO administratie & 13 & erg hoog & constant \\
\hline $\mathrm{HO}$ economie & 11 & erg hoog & - \\
\hline HBO commerciële economie & 17 & erg hoog & sterk stijgend \\
\hline \multicolumn{4}{|l|}{ Beroepen } \\
\hline Economisch-administratieve beroepen & 10 & erg hoog & dalend \\
\hline Receptionisten en administratieve employés & 7 & hoog & - \\
\hline Boekhouders en secretaresses & 3 & laag & sterk dalend \\
\hline Commercieel employés & 11 & erg hoog & constant \\
\hline Commercieel medewerkers & 17 & erg hoog & constant \\
\hline Informatica beroepen & 9 & erg hoog & sterk dalend \\
\hline \multicolumn{4}{|l|}{ Specifieke groepen werkenden } \\
\hline Vrouwen & 11 & erg hoog & constant \\
\hline Jongeren & 14 & erg hoog & stijgend \\
\hline Ouderen & 3 & laag & constant \\
\hline Allochtonen & 9 & erg hoog & sterk stijgend \\
\hline Totaal & 10 & erg hoog & dalend \\
\hline
\end{tabular}

Bron: ROA/CBS

Tabel 10.8

Percentage werkenden dat deelneemt aan scholingstrajecten van 6 maanden of langer, gemiddelde 20012002

Opleidingen
VMBO theorie
HAVO/VWO
MBO economie
MBO administratie
HO economie
HBO commerciële economie

Beroepen

Economisch-administratieve beroepen

Receptionisten en administratieve employés

Boekhouders en secretaresses

Commercieel employés

Commercieel medewerkers

Informatica beroepen

Specifieke groepen werkenden

Vrouwen

Jongeren

Ouderen

Allochtonen

Totaal

$\begin{array}{rll}9 & \text { laag } & - \\ 19 & \text { hoog } & \text { dalend } \\ 16 & \text { hoog } & \text { constant } \\ 21 & \text { erg hoog } & - \\ 17 & \text { hoog } & \text { sterk dalend } \\ 20 & \text { hoog } & \text { sterk dalend }\end{array}$

16 hoog dalend

14 gemiddeld -

17 hoog constant

16 hoog dalend

18 hoog constant

13 gemiddeld sterk stijgend

$\begin{array}{rll}16 & \text { hoog } & \text { sterk dalend } \\ 32 & \text { erg hoog } & \text { dalend } \\ 3 & \text { erg laag } & \text { sterk stijgend } \\ 20 & \text { hoog } & - \\ 16 & \text { hoog } & \text { constant }\end{array}$

Bron: ROA/CBS 
11. Horeca en zakelijke dienstverlening 

Tabel 11.1

Kernindicatoren

\section{Arbeidsomstandigheden}

Belastende arbeidsomstandigheden

$\%$ werknemers dat regelmatig geconfronteerd wordt met:

$\begin{array}{rrl}2000 & 2001 / 2002 & \text { typering } \\ \% & \% & \\ 6 & 7 & \text { gemiddeld } \\ 4 & 4 & \text { gemiddeld } \\ 13 & 14 & \text { gemiddeld } \\ 33 & 31 & \text { gemiddeld } \\ 56 & 58 & \text { gemiddeld }\end{array}$

Lawaai

Trilling

Kracht zetten

Tijdsdruk

Beeldschermwerk

$\begin{array}{rrr} & \begin{array}{r}\text { bedrijven } \\ \%\end{array} \\ & \\ & 42 \\ & 35 \\ & 20 \\ & 15 & \\ & & \\ & & \\ \text { werkenden } & \text { bedrijven } \\ \% & & \\ & & \\ 68 & & \\ 34 & & \\ - & & 83\end{array}$

Vernieuwingen in het productieproces, 1999-2001

Automatisering, 2002

jaarlijks \%

Verschuivingen in de werkgelegenheid

Verwachte werkgelegenheidsontwikkeling, 2003-2008

\section{Scholingsdeelname}

\begin{tabular}{lrr} 
& 2000 typering \\
& $2001 /$ & 2002 \\
$\%$ & $\%$ \\
Deelname aan opleidingstrajecten korter dan 6 maanden (momentopname) & 6 & 4 gemiddeld \\
Deelname aan opleidingstrajecten van 6 maanden of langer (momentopname) & 16 & 17 hoog \\
\hline
\end{tabular}

Bron: ROA/CBS/OSA 


\section{Risicoprofiel}

Figuur 11.1

Sectoraal risicoprofiel

\section{Horeca en zakelijke dienstverlening}

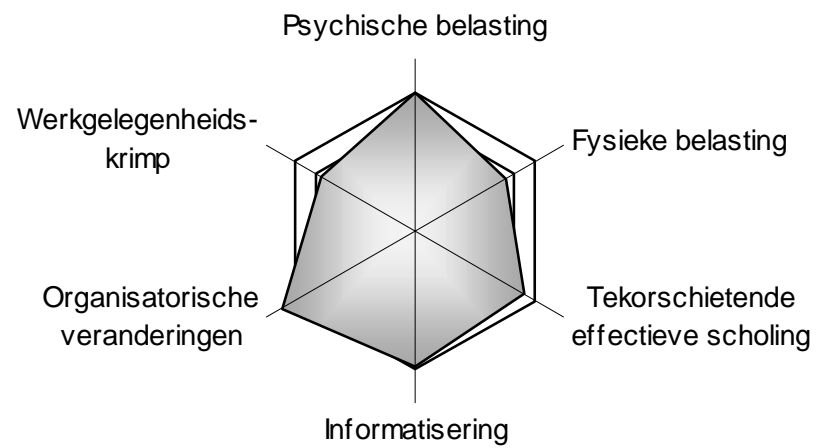

Tabel 11.2

Percentage werkenden dat regelmatig wordt geconfronteerd met lawaai tijdens het werk, gemiddelde 20012002

Opleidingen

Basisonderwijs

VMBO theorie

VMBO natuur en techniek

VMBO economie

VMBO administratie, handel en mode

VMBO verzorging

VMBO (uiterlijke) verzorging

HAVO/VWO

$\mathrm{MBO}$ natuur en techniek

MBO werktuigbouw en mechanische techniek

MBO elektrotechniek

MBO economie

MBO administratie

MBO handel

MBO dienstverlening en gezondheidszorg

MBO uiterlijke verzorging

MBO horeca

$\mathrm{HO}$ natuur en techniek

HBO informatica

$\mathrm{HO}$ economie

HBO accountancy en bedrijfseconomie

HBO bedrijfskunde

$\mathrm{HO}$ onderwijs en sociaal-cultureel
$\%$ typering

trend 2000-2002

sterk stijgend

sterk stijgend

constant

sterk stijgend

sterk stijgend

sterk dalend

constant

sterk stijgend

sterk dalend

sterk dalend

laag

4 gemiddeld

10 gemiddeld

0 gemiddeld

10 gemiddeld

2 laag

1 erg laag

2 laag

2 laag

3 laag

2 laag
-

$-$

constant

constant

sterk stijgend

sterk dalend 
Tabel 11.2 (vervolg)

Percentage werkenden dat regelmatig wordt geconfronteerd met lawaai tijdens het werk, gemiddelde 20012002

$\% \quad$ typering trend $2000-2002$

Beroepen

Pedagogische beroepen

Culturele beroepen

Technische, ambachts- en industrieberoepen

Productiemedewerkers

Transportberoepen

Laders en lossers

Chauffeurs

Economisch-administratieve beroepen

Kantoorhulpen, inpakkers en colporteurs

Receptionisten en administratieve employés

Boekhouders en secretaresses

Assistent accountants

Commercieel employés

Commercieel medewerkers

Informatica beroepen

Programmeurs

Systeemanalisten

Sociaal-culturele beroepen

Verzorgende en dienstverlenende beroepen

Interieurverzorgers

Hulpkrachten horeca en verzorging

Verzorgend personeel

Bedrijfshoofden horeca

Openbare orde- en veiligheidsberoepen

Aspirant politieagenten, soldaten en beveiligingshulpkrachten

\begin{tabular}{|c|c|c|}
\hline 20 & hoog & - \\
\hline 0 & erg laag & - \\
\hline 12 & hoog & - \\
\hline 23 & hoog & sterk stijgend \\
\hline 33 & erg hoog & sterk stijgend \\
\hline 36 & erg hoog & sterk stijgend \\
\hline 27 & hoog & - \\
\hline 3 & laag & - \\
\hline 31 & erg hoog & - \\
\hline 2 & laag & - \\
\hline 2 & laag & dalend \\
\hline 1 & erg laag & constant \\
\hline 2 & laag & sterk dalend \\
\hline 0 & erg laag & sterk dalend \\
\hline 1 & erg laag & - \\
\hline 2 & laag & - \\
\hline 1 & erg laag & sterk stijgend \\
\hline 3 & laag & sterk dalend \\
\hline 12 & hoog & stijgend \\
\hline 13 & hoog & sterk stijgend \\
\hline 14 & hoog & sterk stijgend \\
\hline 9 & gemiddeld & - \\
\hline 11 & gemiddeld & sterk dalend \\
\hline 2 & laag & - \\
\hline 2 & laag & - \\
\hline 5 & gemiddeld & - \\
\hline 8 & gemiddeld & sterk stijgend \\
\hline 7 & gemiddeld & - \\
\hline 14 & hoog & stijgend \\
\hline 7 & gemiddeld & - \\
\hline
\end{tabular}

Specifieke Groepen Werkenden

$\begin{array}{lrll}\text { Vrouwen } & 5 & \text { gemiddeld } & - \\ \text { Jongeren } & 8 & \text { gemiddeld } & \text { sterk stijgend } \\ \text { Ouderen } & 7 & \text { gemiddeld } & - \\ \text { Allochtonen } & 14 & \text { hoog } & \text { stijgend } \\ \text { Totaal } & 7 & \text { gemiddeld } & -\end{array}$

Bron: ROA/CBS 
Horeca en zakelijke dienstverlening

Tabel 11.3

Percentage werkenden dat regelmatig werkt met trillende apparaten, gemiddelde 2001-2002

\begin{tabular}{|c|c|c|c|}
\hline & $\%$ & typering & trend $2000-2002$ \\
\hline \multicolumn{4}{|l|}{ Opleidingen } \\
\hline Basisonderwijs & 7 & gemiddeld & constant \\
\hline VMBO theorie & 5 & gemiddeld & sterk stijgend \\
\hline VMBO natuur en techniek & 17 & hoog & dalend \\
\hline VMBO economie & 3 & gemiddeld & sterk dalend \\
\hline VMBO administratie, handel en mode & 1 & laag & - \\
\hline VMBO verzorging & 1 & laag & - \\
\hline VMBO (uiterlijke) verzorging & 1 & laag & - \\
\hline HAVO/VWO & 1 & laag & - \\
\hline MBO natuur en techniek & 8 & gemiddeld & sterk dalend \\
\hline MBO elektrotechniek & 4 & gemiddeld & - \\
\hline MBO economie & 2 & gemiddeld & - \\
\hline MBO administratie & 1 & laag & - \\
\hline MBO handel & 4 & gemiddeld & sterk stijgend \\
\hline MBO secretariaat & 1 & laag & - \\
\hline MBO dienstverlening en gezondheidszorg & 6 & gemiddeld & - \\
\hline MBO uiterlijke verzorging & 21 & hoog & sterk stijgend \\
\hline MBO horeca & 2 & gemiddeld & - \\
\hline $\mathrm{HO}$ natuur en techniek & 1 & laag & sterk dalend \\
\hline HBO informatica & 1 & laag & sterk stijgend \\
\hline $\mathrm{HO}$ economie & 0 & laag & - \\
\hline HBO accountancy en bedrijfseconomie & 1 & laag & sterk stijgend \\
\hline HBO bedrijfskunde & 1 & laag & sterk stijgend \\
\hline \multicolumn{4}{|l|}{ Beroepen } \\
\hline Culturele beroepen & 0 & erg laag & sterk dalend \\
\hline Technische, ambachts- en industrieberoepen & 11 & gemiddeld & dalend \\
\hline Monteurs & 22 & hoog & sterk stijgend \\
\hline Transportberoepen & 13 & hoog & sterk stijgend \\
\hline Economisch-administratieve beroepen & 1 & laag & - \\
\hline Receptionisten en administratieve employés & 0 & erg laag & sterk dalend \\
\hline Boekhouders en secretaresses & 1 & laag & - \\
\hline Commercieel employés & 1 & laag & - \\
\hline Informatica beroepen & 0 & laag & - \\
\hline Systeemanalisten & 0 & erg laag & sterk stijgend \\
\hline Verzorgende en dienstverlenende beroepen & 5 & erg laag & - \\
\hline Interieurverzorgers & 4 & gemiddeld & - \\
\hline Hulpkrachten horeca en verzorging & 2 & laag & sterk stijgend \\
\hline Verzorgend personeel & 12 & hoog & sterk stijgend \\
\hline Bedrijfshoofden horeca & 3 & gemiddeld & - \\
\hline Openbare orde- en veiligheidsberoepen & 2 & laag & constant \\
\hline Aspirant politieagenten, soldaten en beveiligingshulpkrachten & 2 & laag & constant \\
\hline \multicolumn{4}{|l|}{ Specifieke Groepen Werkenden } \\
\hline Vrouwen & 2 & laag & - \\
\hline Jongeren & 3 & gemiddeld & sterk stijgend \\
\hline Ouderen & 4 & gemiddeld & dalend \\
\hline Allochtonen & 4 & gemiddeld & - \\
\hline Totaal & 4 & gemiddeld & - \\
\hline
\end{tabular}

Bron: ROA/CBS 
Tabel 11.4

Percentage werkenden dat regelmatig kracht moet zetten tijdens het werk, gemiddelde 2001-2002

\begin{tabular}{|c|c|c|c|}
\hline & $\%$ & typering & trend $2000-2002$ \\
\hline \multicolumn{4}{|l|}{ Opleidingen } \\
\hline Basisonderwijs & 30 & gemiddeld & constant \\
\hline VMBO theorie & 18 & gemiddeld & sterk stijgend \\
\hline VMBO natuur en techniek & 41 & hoog & sterk dalend \\
\hline VMBO economie & 19 & gemiddeld & - \\
\hline VMBO administratie, handel en mode & 20 & gemiddeld & - \\
\hline VMBO consumptief en levensmiddelentechniek & 28 & gemiddeld & sterk stijgend \\
\hline VMBO verzorging & 30 & gemiddeld & sterk stijgend \\
\hline VMBO (uiterlijke) verzorging & 30 & gemiddeld & sterk stijgend \\
\hline HAVO/VWO & 11 & gemiddeld & sterk dalend \\
\hline MBO natuur en techniek & 17 & gemiddeld & sterk stijgend \\
\hline MBO elektrotechniek & 11 & gemiddeld & sterk dalend \\
\hline MBO economie & 10 & gemiddeld & - \\
\hline MBO administratie & 5 & gemiddeld & constant \\
\hline MBO handel & 23 & gemiddeld & - \\
\hline MBO secretariaat & 1 & laag & constant \\
\hline MBO bedrijfskunde & 28 & gemiddeld & - \\
\hline MBO dienstverlening en gezondheidszorg & 20 & gemiddeld & - \\
\hline MBO uiterlijke verzorging & 11 & gemiddeld & sterk stijgend \\
\hline MBO horeca & 27 & gemiddeld & - \\
\hline $\mathrm{HO}$ natuur en techniek & 2 & laag & - \\
\hline HBO informatica & 3 & laag & constant \\
\hline $\mathrm{HO}$ economie & 1 & laag & - \\
\hline HBO accountancy en bedrijfseconomie & 2 & laag & sterk dalend \\
\hline HBO bedrijfskunde & 4 & gemiddeld & sterk stijgend \\
\hline $\mathrm{HO}$ onderwijs en sociaal-cultureel & 5 & gemiddeld & - \\
\hline \multicolumn{4}{|l|}{ Beroepen } \\
\hline Culturele beroepen & 10 & gemiddeld & - \\
\hline Agrarische beroepen & 28 & gemiddeld & - \\
\hline Technische, ambachts- en industrieberoepen & 23 & gemiddeld & stijgend \\
\hline Productiemedewerkers & 38 & hoog & sterk dalend \\
\hline Monteurs & 41 & hoog & sterk stijgend \\
\hline Transportberoepen & 53 & erg hoog & - \\
\hline Laders en lossers & 59 & erg hoog & sterk dalend \\
\hline Chauffeurs & 45 & hoog & sterk stijgend \\
\hline Economisch-administratieve beroepen & 3 & laag & constant \\
\hline Kantoorhulpen, inpakkers en colporteurs & 36 & hoog & sterk dalend \\
\hline Receptionisten en administratieve employés & 2 & laag & sterk stijgend \\
\hline Boekhouders en secretaresses & 1 & laag & - \\
\hline Assistent accountants & 1 & laag & sterk stijgend \\
\hline Commercieel employés & 2 & laag & sterk stijgend \\
\hline Commercieel medewerkers & 2 & laag & sterk stijgend \\
\hline Juristen & 1 & laag & constant \\
\hline Informatica beroepen & 1 & laag & sterk dalend \\
\hline Programmeurs & 3 & laag & sterk dalend \\
\hline Systeemanalisten & 1 & laag & sterk dalend \\
\hline Sociaal-culturele beroepen & 0 & erg laag & dalend \\
\hline Verzorgende en dienstverlenende beroepen & 30 & gemiddeld & constant \\
\hline Interieurverzorgers & 32 & hoog & dalend \\
\hline Hulpkrachten horeca en verzorging & 32 & hoog & - \\
\hline Verzorgend personeel & 23 & gemiddeld & stijgend \\
\hline
\end{tabular}


Horeca en zakelijke dienstverlening

Tabel 11.4 (vervolg)

Percentage werkenden dat regelmatig kracht moet zetten tijdens het werk, gemiddelde 2001-2002

\begin{tabular}{|c|c|c|c|}
\hline & $\%$ & typering & trend 2000-2002 \\
\hline Bedrijfshoofden horeca & 27 & gemiddeld & sterk dalend \\
\hline Openbare orde- en veiligheidsberoepen & 1 & laag & sterk dalend \\
\hline Aspirant politieagenten, soldaten en beveiligingshulpkrachten & 0 & erg laag & sterk dalend \\
\hline \multicolumn{4}{|l|}{ Specifieke groepen werkenden } \\
\hline Vrouwen & 13 & gemiddeld & sterk stijgend \\
\hline Jongeren & 13 & gemiddeld & - \\
\hline Ouderen & 16 & gemiddeld & sterk stijgend \\
\hline Allochtonen & 18 & gemiddeld & sterk dalend \\
\hline Totaal & 14 & gemiddeld & constant \\
\hline
\end{tabular}

Bron: ROA/CBS 
Horeca en zakelijke dienstverlening

Tabel 11.5

Percentage werkenden dat regelmatig onder hoge tijdsdruk werkt, gemiddelde 2001-2002

\begin{tabular}{|c|c|c|c|}
\hline & $\%$ & typering & trend $2000-2002$ \\
\hline \multicolumn{4}{|l|}{ Opleidingen } \\
\hline Basisonderwijs & 26 & gemiddeld & dalend \\
\hline VMBO theorie & 27 & gemiddeld & dalend \\
\hline VMBO natuur en techniek & 23 & laag & sterk stijgend \\
\hline VMBO economie & 29 & gemiddeld & constant \\
\hline VMBO administratie, handel en mode & 25 & laag & sterk dalend \\
\hline VMBO consumptief en levensmiddelentechniek & 43 & hoog & - \\
\hline VMBO verzorging & 23 & laag & dalend \\
\hline VMBO (uiterlijke) verzorging & 23 & laag & dalend \\
\hline HAVO/VWO & 30 & gemiddeld & dalend \\
\hline MBO natuur en techniek & 26 & gemiddeld & dalend \\
\hline MBO werktuigbouw en mechanische techniek & 25 & laag & sterk dalend \\
\hline MBO elektrotechniek & 26 & gemiddeld & constant \\
\hline MBO automatisering & 30 & gemiddeld & - \\
\hline MBO economie & 29 & gemiddeld & dalend \\
\hline MBO administratie & 30 & gemiddeld & dalend \\
\hline MBO handel & 25 & laag & - \\
\hline MBO secretariaat & 24 & laag & - \\
\hline MBO bedrijfskunde & 40 & hoog & dalend \\
\hline MBO dienstverlening en gezondheidszorg & 34 & gemiddeld & constant \\
\hline MBO verzorging & 34 & gemiddeld & - \\
\hline MBO uiterlijke verzorging & 29 & gemiddeld & - \\
\hline MBO horeca & 40 & hoog & dalend \\
\hline $\mathrm{HO}$ natuur en techniek & 31 & gemiddeld & dalend \\
\hline HBO elektrotechniek & 29 & gemiddeld & - \\
\hline HBO informatica & 34 & gemiddeld & - \\
\hline WO wiskunde en natuurwetenschappen & 36 & gemiddeld & - \\
\hline $\mathrm{HO}$ economie & 43 & hoog & constant \\
\hline HBO accountancy en bedrijfseconomie & 42 & hoog & stijgend \\
\hline HBO commerciële economie & 35 & gemiddeld & - \\
\hline HBO bedrijfskunde & 36 & gemiddeld & - \\
\hline WO econom(etr)ie & 49 & erg hoog & - \\
\hline WO bedrijfskunde & 36 & gemiddeld & sterk dalend \\
\hline WO accountancy en belastingen & 60 & erg hoog & constant \\
\hline WO rechten en bestuurskunde & 61 & erg hoog & stijgend \\
\hline $\mathrm{HO}$ onderwijs en sociaal-cultureel & 37 & gemiddeld & dalend \\
\hline \multicolumn{4}{|l|}{ Beroepen } \\
\hline Culturele beroepen & 30 & gemiddeld & constant \\
\hline Agrarische beroepen & 21 & laag & dalend \\
\hline Technische, ambachts- en industrieberoepen & 28 & gemiddeld & - \\
\hline Productiemedewerkers & 28 & gemiddeld & sterk stijgend \\
\hline Aannemers en installateurs & 23 & laag & - \\
\hline Architecten en bouwkundig projectleiders & 34 & gemiddeld & dalend \\
\hline Weg- en waterbouwkundigen & 32 & gemiddeld & sterk dalend \\
\hline Monteurs & 22 & laag & - \\
\hline Transportberoepen & 22 & laag & - \\
\hline Chauffeurs & 29 & gemiddeld & sterk stijgend \\
\hline Economisch-administratieve beroepen & 35 & gemiddeld & constant \\
\hline Kantoorhulpen, inpakkers en colporteurs & 35 & gemiddeld & sterk stijgend \\
\hline Bedrijfshoofden & 44 & erg hoog & sterk stijgend \\
\hline Organisatie-adviseurs & 33 & gemiddeld & constant \\
\hline
\end{tabular}


Horeca en zakelijke dienstverlening

Tabel 11.5 (vervolg)

Percentage werkenden dat regelmatig onder hoge tijdsdruk werkt, gemiddelde 2001-2002

\begin{tabular}{|c|c|c|c|}
\hline & $\%$ & typering & trend $2000-2002$ \\
\hline Organisatiedeskundigen & 58 & erg hoog & constant \\
\hline Receptionisten en administratieve employés & 21 & laag & sterk stijgend \\
\hline Boekhouders en secretaresses & 25 & laag & sterk dalend \\
\hline Assistent accountants & 38 & gemiddeld & sterk stijgend \\
\hline Accountants & 51 & erg hoog & constant \\
\hline Commercieel employés & 34 & gemiddeld & sterk dalend \\
\hline Commercieel medewerkers & 44 & erg hoog & dalend \\
\hline Juristen & 56 & erg hoog & - \\
\hline Leidinggevenden & 48 & erg hoog & constant \\
\hline Managers & 49 & erg hoog & sterk dalend \\
\hline Informatica beroepen & 29 & gemiddeld & dalend \\
\hline Programmeurs & 25 & laag & sterk dalend \\
\hline Systeemanalisten & 31 & gemiddeld & dalend \\
\hline Informatici & 32 & gemiddeld & - \\
\hline Sociaal-culturele beroepen & 33 & gemiddeld & sterk dalend \\
\hline Activiteitenbegeleiders en medewerkers arbeidsbemiddeling & 32 & gemiddeld & - \\
\hline Medewerkers sociaal-cultureel werk en personeel en arbeid & 32 & gemiddeld & sterk dalend \\
\hline Verzorgende en dienstverlenende beroepen & 32 & gemiddeld & constant \\
\hline Interieurverzorgers & 26 & gemiddeld & constant \\
\hline Hulpkrachten horeca en verzorging & 36 & gemiddeld & constant \\
\hline Verzorgend personeel & 34 & gemiddeld & constant \\
\hline Bedrijfshoofden horeca & 45 & erg hoog & constant \\
\hline Openbare orde- en veiligheidsberoepen & 16 & erg laag & sterk dalend \\
\hline Aspirant politieagenten, soldaten en beveiligingshulpkrachten & 16 & erg laag & sterk dalend \\
\hline \multicolumn{4}{|l|}{ Specifieke groepen werkenden } \\
\hline Vrouwen & 29 & gemiddeld & constant \\
\hline Jongeren & 28 & gemiddeld & - \\
\hline Ouderen & 29 & gemiddeld & - \\
\hline Allochtonen & 34 & gemiddeld & stijgend \\
\hline Totaal & 31 & gemiddeld & dalend \\
\hline
\end{tabular}

Bron: ROA/CBS 
Horeca en zakelijke dienstverlening

Tabel 11.6

Percentage werkenden dat regelmatig beeldschermwerk verricht, gemiddelde 2001-2002

\begin{tabular}{|c|c|c|c|}
\hline & $\%$ & typering & trend $2000-2002$ \\
\hline \multicolumn{4}{|l|}{ Opleidingen } \\
\hline Basisonderwijs & 13 & laag & - \\
\hline VMBO theorie & 41 & gemiddeld & sterk dalend \\
\hline VMBO natuur en techniek & 17 & laag & stijgend \\
\hline VMBO economie & 30 & gemiddeld & - \\
\hline VMBO administratie, handel en mode & 40 & gemiddeld & constant \\
\hline VMBO verzorging & 15 & laag & - \\
\hline VMBO (uiterlijke) verzorging & 15 & laag & - \\
\hline HAVO/VWO & 64 & gemiddeld & stijgend \\
\hline MBO natuur en techniek & 51 & gemiddeld & stijgend \\
\hline MBO bouw & 59 & gemiddeld & constant \\
\hline MBO werktuigbouw en mechanische techniek & 58 & gemiddeld & dalend \\
\hline MBO elektrotechniek & 68 & gemiddeld & constant \\
\hline MBO grafische techniek & 83 & hoog & sterk stijgend \\
\hline MBO automatisering & 91 & erg hoog & dalend \\
\hline MBO openbare orde en veiligheid & 43 & gemiddeld & - \\
\hline MBO economie & 79 & hoog & constant \\
\hline MBO administratie & 86 & hoog & constant \\
\hline MBO handel & 61 & gemiddeld & sterk stijgend \\
\hline MBO secretariaat & 96 & erg hoog & stijgend \\
\hline MBO bedrijfskunde & 62 & gemiddeld & sterk dalend \\
\hline MBO dienstverlening en gezondheidszorg & 25 & gemiddeld & sterk dalend \\
\hline MBO sociaal-cultureel & 71 & gemiddeld & - \\
\hline MBO verzorging & 33 & gemiddeld & sterk stijgend \\
\hline MBO uiterlijke verzorging & 7 & erg laag & - \\
\hline MBO horeca & 20 & laag & sterk dalend \\
\hline $\mathrm{HO}$ natuur en techniek & 87 & hoog & stijgend \\
\hline HBO milieukunde en levensmiddelentechnologie & 83 & hoog & dalend \\
\hline HBO bouwkunde & 84 & hoog & sterk stijgend \\
\hline HBO civiele techniek & 76 & gemiddeld & - \\
\hline HBO werktuigbouwkunde & 87 & hoog & constant \\
\hline HBO elektrotechniek & 88 & hoog & constant \\
\hline HBO informatica & 91 & erg hoog & constant \\
\hline WO wiskunde en natuurwetenschappen & 93 & erg hoog & - \\
\hline WO bouwkunde & 65 & gemiddeld & - \\
\hline WO civiele techniek & 88 & hoog & sterk stijgend \\
\hline WO elektrotechniek & 100 & erg hoog & sterk stijgend \\
\hline WO informatica en bestuurlijke informatiekunde & 97 & erg hoog & constant \\
\hline $\mathrm{HO}$ economie & 90 & hoog & stijgend \\
\hline HBO accountancy en bedrijfseconomie & 95 & erg hoog & - \\
\hline HBO commerciële economie & 92 & erg hoog & stijgend \\
\hline HBO recht en bestuur & 90 & hoog & sterk stijgend \\
\hline HBO secretariaat & 89 & hoog & dalend \\
\hline HBO bedrijfskunde & 88 & hoog & constant \\
\hline WO econom(etr)ie & 89 & hoog & sterk stijgend \\
\hline WO bedrijfskunde & 93 & erg hoog & stijgend \\
\hline WO accountancy en belastingen & 85 & hoog & constant \\
\hline WO rechten en bestuurskunde & 85 & hoog & constant \\
\hline $\mathrm{HO}$ onderwijs en sociaal-cultureel & 74 & gemiddeld & dalend \\
\hline HBO communicatie en journalistiek & 79 & hoog & stijgend \\
\hline HBO maatschappelijk werk en hulpverlening & 66 & gemiddeld & stijgend \\
\hline HBO personeel en arbeid & 93 & erg hoog & dalend \\
\hline
\end{tabular}


Tabel 11.6 (vervolg)

Percentage werkenden dat regelmatig beeldschermwerk verricht, gemiddelde 2001-2002

\begin{tabular}{|c|c|c|c|}
\hline & $\%$ & typering & trend 2000-2002 \\
\hline $\begin{array}{l}\text { HBO bibliotheek en documentatie } \\
\text { HBO uitvoerende en beeldende kunsten } \\
\text { WO letteren } \\
\text { WO sociale wetenschappen } \\
\text { HO medisch }\end{array}$ & $\begin{array}{l}86 \\
59 \\
98 \\
72 \\
79\end{array}$ & $\begin{array}{l}\text { hoog } \\
\text { gemiddeld } \\
\text { erg hoog } \\
\text { gemiddeld } \\
\text { hoog }\end{array}$ & $\begin{array}{l}\text { stijgend } \\
\text { - } \\
\text { stijgend } \\
\text { dalend } \\
\text { dalend }\end{array}$ \\
\hline \multicolumn{4}{|l|}{ Beroepen } \\
\hline Pedagogische beroepen & 28 & gemiddeld & - \\
\hline Culturele beroepen & 81 & hoog & - \\
\hline Bibliotheekassistenten & 85 & hoog & constant \\
\hline Agrarische beroepen & 40 & gemiddeld & constant \\
\hline Milieuhygiënisten en agrarisch vertegenwoordigers & 77 & hoog & - \\
\hline Technische, ambachts- en industrieberoepen & 47 & gemiddeld & - \\
\hline Aannemers en installateurs & 67 & gemiddeld & dalend \\
\hline Architecten en bouwkundig projectleiders & 70 & gemiddeld & constant \\
\hline Weg- en waterbouwkundigen & 79 & hoog & - \\
\hline Weg- en waterbouwkundig ontwerpers en projectleiders & 74 & gemiddeld & - \\
\hline Monteurs & 30 & gemiddeld & sterk stijgend \\
\hline Werktuigbouwkundig ontwerpers en hoofden technische dienst & 97 & erg hoog & sterk stijgend \\
\hline Elektromonteurs & 51 & gemiddeld & sterk stijgend \\
\hline Elektrotechnici & 100 & erg hoog & constant \\
\hline Transportberoepen & 7 & erg laag & constant \\
\hline Economisch-administratieve beroepen & 86 & hoog & constant \\
\hline Bedriifshoofden & 80 & hoog & constant \\
\hline Productieplanners & 72 & gemiddeld & - \\
\hline Organisatie-adviseurs & 88 & hoog & constant \\
\hline Organisatiedeskundigen & 82 & hoog & sterk dalend \\
\hline Receptionisten en administratieve employés & 89 & hoog & constant \\
\hline Boekhouders en secretaresses & 95 & erg hoog & constant \\
\hline Assistent accountants & 96 & erg hoog & stijgend \\
\hline Accountants & 92 & erg hoog & dalend \\
\hline Commercieel employés & 84 & hoog & - \\
\hline Commercieel medewerkers & 84 & hoog & dalend \\
\hline Technisch-bedrijfskundig medewerkers & 90 & hoog & constant \\
\hline Juridisch en fiscaal medewerkers & 89 & hoog & constant \\
\hline Juridisch, bestuurlijk medewerkers & 96 & erg hoog & constant \\
\hline Juristen & 86 & hoog & constant \\
\hline Leidinggevenden & 64 & gemiddeld & dalend \\
\hline Managers & 84 & hoog & sterk stijgend \\
\hline Informatica beroepen & 95 & erg hoog & constant \\
\hline Programmeurs & 99 & erg hoog & constant \\
\hline Systeemanalisten & 95 & erg hoog & constant \\
\hline Informatici & 89 & hoog & - \\
\hline Technisch systeemanalisten & 97 & erg hoog & constant \\
\hline Sociaal-culturele beroepen & 90 & hoog & stijgend \\
\hline Activiteitenbegeleiders en medewerkers arbeidsbemiddeling & 89 & hoog & constant \\
\hline Medewerkers sociaal-cultureel werk en personeel en arbeid & 92 & erg hoog & - \\
\hline Verzorgende en dienstverlenende beroepen & 7 & erg laag & sterk dalend \\
\hline Interieurverzorgers & 3 & erg laag & sterk dalend \\
\hline Hulpkrachten horeca en verzorging & 3 & erg laag & constant \\
\hline Verzorgend personeel & 5 & erg laag & sterk dalend \\
\hline Bedrijfshoofden horeca & 27 & gemiddeld & - \\
\hline Openbare orde- en veiligheidsberoepen & 36 & gemiddeld & - \\
\hline Aspirant politieagenten, soldaten en beveiligingshulpkrachten & 32 & gemiddeld & - \\
\hline
\end{tabular}


Horeca en zakelijke dienstverlening

Tabel 11.6 (vervolg)

Percentage werkenden dat regelmatig beeldschermwerk verricht, gemiddelde 2001-2002

$\% \quad$ typering trend $2000-2002$

Specifieke groepen werkenden

Vrouwen

Jongeren

Ouderen

gemiddeld

constant

Allochtonen

gemiddeld

stijgend

Totaal

58 gemiddeld

constant

Bron: ROA/CBS 
Tabel 11.7

Percentage werkenden dat deelneemt aan scholingstrajecten korter dan 6 maanden, gemiddelde 2001-2002

$\% \quad$ typering trend $2000-2002$

Opleidingen

Basisonderwijs

VMBO theorie

VMBO natuur en techniek

VMBO economie

VMBO administratie, handel en mode

VMBO verzorging

VMBO (uiterlijke) verzorging

$\mathrm{HAVO} / \mathrm{VWO}$

MBO natuur en techniek

MBO elektrotechniek

$\mathrm{MBO}$ economie

MBO administratie

MBO handel

MBO secretariaat

MBO dienstverlening en gezondheidszorg

MBO uiterlijke verzorging

MBO horeca

$\mathrm{HO}$ natuur en techniek

$\mathrm{HBO}$ informatica

$\mathrm{HO}$ economie

HBO accountancy en bedrijfseconomie

HBO bedrijfskunde

WO rechten en bestuurskunde

$\mathrm{HO}$ onderwijs en sociaal-cultureel

\%

Beroepen

Culturele beroepen

Technische, ambachts- en industrieberoepen

Transportberoepen

Economisch-administratieve beroepen

Receptionisten en administratieve employés

Boekhouders en secretaresses

Assistent accountants

Accountants

Commercieel employés

Commercieel medewerkers

Juristen

Informatica beroepen

Programmeurs

Systeemanalisten

Informatici

Sociaal-culturele beroepen

Verzorgende en dienstverlenende beroepen

Interieurverzorgers

Hulpkrachten horeca en verzorging

Verzorgend personeel

Bedrijfshoofden horeca

Openbare orde- en veiligheidsberoepen

Aspirant politieagenten, soldaten en beveiligingshulpkrachten

\begin{tabular}{|c|c|c|}
\hline 4 & gemiddeld & atols dond \\
\hline & laag & sterk dalend \\
\hline & gemiddeld & sterk dalend \\
\hline & gemiddeld & - \\
\hline & gemiddeld & - \\
\hline 2 & laag & sterk dalend \\
\hline & laag & sterk dalend \\
\hline & gemiddeld & sterk dalend \\
\hline & gemiddeld & constant \\
\hline & erg hoog & constant \\
\hline & gemiddeld & sterk dalend \\
\hline & laag & sterk dalend \\
\hline & gemiddeld & sterk dalend \\
\hline & laag & - \\
\hline 3 & laag & sterk dalend \\
\hline 2 & laag & sterk dalend \\
\hline & gemiddeld & - \\
\hline & gemiddeld & sterk dalend \\
\hline & erg hoog & - \\
\hline & gemiddeld & sterk dalend \\
\hline & laag & sterk dalend \\
\hline & hoog & - \\
\hline 5 & gemiddeld & - \\
\hline & gemiddeld & sterk dalend \\
\hline 3 & laag & - \\
\hline & gemiddeld & - \\
\hline & laag & sterk dalend \\
\hline & laag & sterk dalend \\
\hline & laag & sterk dalend \\
\hline & laag & sterk dalend \\
\hline & laag & - \\
\hline & laag & sterk stijgend \\
\hline & laag & - \\
\hline & gemiddeld & - \\
\hline & gemiddeld & - \\
\hline & erg hoog & sterk dalend \\
\hline & erg hoog & sterk dalend \\
\hline & erg hoog & - \\
\hline & erg hoog & constant \\
\hline & hoog & sterk dalend \\
\hline 2 & laag & sterk dalend \\
\hline & laag & sterk dalend \\
\hline & laag & sterk dalend \\
\hline & laag & - \\
\hline & gemiddeld & - \\
\hline & $g$ hoog & ste \\
\hline & & sterk stijgend \\
\hline
\end{tabular}


Horeca en zakelijke dienstverlening

Tabel 11.7 (vervolg)

Percentage werkenden dat deelneemt aan scholingstrajecten korter dan 6 maanden, gemiddelde 2001-2002

$\% \quad$ typering trend $2000-2002$

Specifieke groepen werkenden

Vrouwen

Jongeren

Ouderen

4 gemiddeld

Allochtonen

gemiddeld

sterk dalend

Totaal

4 gemiddeld

stijgend

sterk dalend

Bron: ROA/CBS 
Tabel 11.8

Percentage werkenden dat deelneemt aan scholingstrajecten van 6 maanden of langer, gemiddelde 20012002

$\% \quad$ typering trend $2000-2002$

Opleidingen

Basisonderwijs

VMBO theorie

VMBO natuur en techniek

VMBO economie

VMBO administratie, handel en mode

VMBO verzorging

VMBO (uiterlijke) verzorging

$\mathrm{HAVO} / \mathrm{VWO}$

$\mathrm{MBO}$ natuur en techniek

MBO elektrotechniek

$\mathrm{MBO}$ economie

MBO administratie

MBO handel

MBO secretariaat

MBO dienstverlening en gezondheidszorg

MBO uiterlijke verzorging

MBO horeca

$\mathrm{HO}$ natuur en techniek

HBO informatica

$\mathrm{HO}$ economie

HBO accountancy en bedrijfseconomie

HBO bedriifskunde

WO rechten en bestuurskunde

$\mathrm{HO}$ onderwijs en sociaal-culturee

Beroepen

Pedagogische beroepen

Culturele beroepen

Technische, ambachts- en industrieberoepen

Transportberoepen

Economisch-administratieve beroepen

Receptionisten en administratieve employés

Boekhouders en secretaresses

Assistent accountants

Accountants

Commercieel employés

Commercieel medewerkers

Juristen

Informatica beroepen

Programmeurs

Systeemanalisten

Informatici

Sociaal-culturele beroepen

Activiteitenbegeleiders en medewerkers arbeidsbemiddeling

Verzorgende en dienstverlenende beroepen

Interieurverzorgers

Hulpkrachten horeca en verzorging

Verzorgend personeel

Bedrijfshoofden horeca

Openbare orde- en veiligheidsberoepen

Aspirant politieagenten, soldaten en beveiligingshulpkrachten gemiddeld

erg hoog

gemiddeld

hoog

hoog

gemiddeld

gemiddeld

erg hoog

gemiddeld

hoog

gemiddeld

hoog

gemiddeld

laag

gemiddeld

laag

gemiddeld

gemiddeld

hoog

erg hoog

erg hoog

hoog

hoog

hoog

\section{hoog}

gemiddeld

gemiddeld

laag

hoog

hoog

gemiddeld

erg hoog

erg hoog

hoog

gemiddeld

erg hoog

hoog

erg hoog

hoog

gemiddeld

hoog

erg hoog

erg hoog

hoog

erg hoog

hoog

gemiddeld

hoog

erg hoog sterk stijgend

sterk stijgend

constant

constant

constant

constant

constant

constant

constant

sterk dalend

sterk stijgend

sterk stijgend

sterk stijgend

sterk stijgend

sterk stijgend

sterk stijgend

constant

sterk stijgend

sterk dalend

-

constant

constant

sterk stijgend

-

stijgend

sterk stijgend

sterk stijgend

sterk stijgend

stijgend

stijgend

sterk stijgend

sterk dalend 
Horeca en zakelijke dienstverlening

Tabel 11.8 (vervolg)

Percentage werkenden dat deelneemt aan scholingstrajecten van 6 maanden of langer, gemiddelde 20012002

$\% \quad$ typering trend 2000-2002

Specifieke groepen werkenden

Vrouwen

Jongeren

Ouderen

Allochtonen

15 hoog

32 erg hoog stijgend

Totaal

3 erg laag

sterk dalend

25 erg hoog sterk stijgend

17 hoog

stijgend

Bron: ROA/CBS

Tabel 11.9

Doelgroepen voor het scholingsbeleid en risicofactoren

Doelgroepen

risicofactor(en)

Organisatiedeskundigen

tijdsdruk 

12. Kwartaire diensten 

Tabel 12.1

Kernindicatoren

\section{Arbeidsomstandigheden}

Belastende arbeidsomstandigheden

$\%$ werknemers dat regelmatig geconfronteerd wordt met:

$\begin{array}{rrl}\begin{array}{r}2000 \\ \%\end{array} & 2001 / 2002 & \text { typering } \\ \% & & \\ 5 & 4 & \text { gemiddeld } \\ 3 & 2 & \text { laag } \\ 32 & 32 & \text { hoog } \\ 38 & 34 & \text { gemiddeld } \\ 32 & 35 & \text { gemiddeld }\end{array}$

Lawaai

Trilling

Kracht zetten

Tijdsdruk

Beeldschermwerk

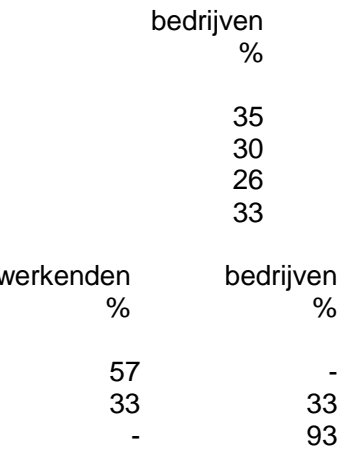

Vernieuwingen in het productieproces, 1999-2001

Automatisering, 2002

jaarlijks \%

Kleine productverandering, 2000-2002

Ingrijpende productverandering, 2000-2002

Veranderingen in positie, 2000-2002

Interne reorganisaties, 2000-2002

Technologische vernieuwingen

Verschuivingen in de werkgelegenheid

Verwachte werkgelegenheidsontwikkeling, 2003-2008

Scholingsdeelname

$\begin{array}{rrr}2000 & 2001 / & \text { typering } \\ & 2002 & \\ \% & \% & \\ & & \\ 4 & 4 & \text { gemiddeld } \\ 14 & 14 & \text { gemiddeld }\end{array}$

Deelname aan opleidingstrajecten korter dan 6 maanden (momentopname) Deelname aan opleidingstrajecten van 6 maanden of langer (momentopname)

14 gemiddeld

Bron: ROA/CBS/OSA 


\section{Risicoprofiel}

Figuur 12.1

Sectoraal risicoprofiel

\section{Kwartaire diensten}

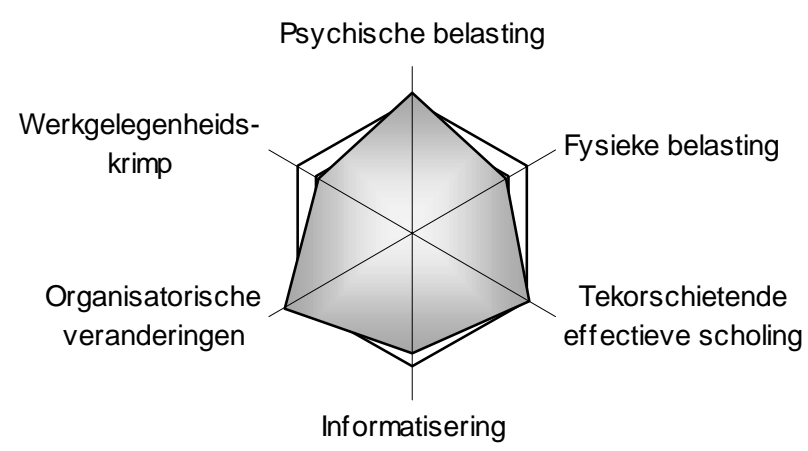

Tabel 12.2

Percentage werkenden dat regelmatig wordt geconfronteerd met lawaai tijdens het werk, gemiddelde 20012002

$\% \quad$ typering trend $2000-2002$

Opleidingen

Basisonderwijs

VMBO theorie

VMBO economie

VMBO verzorging

VMBO (uiterlijke) verzorging

HAVO/VWO

MBO natuur en techniek

$\mathrm{MBO}$ economie

MBO administratie

MBO secretariaat

MBO dienstverlening en gezondheidszorg

MBO dokters-, tandarts- en dierenartsassistent

$M B O$ verpleging

MBO sociaal-cultureel

$\mathrm{MBO}$ verzorging

$\mathrm{HO}$ natuur en techniek

$\mathrm{HO}$ economie

$\mathrm{HO}$ onderwijs en sociaal-cultureel

HBO maatschappelijk werk en hulpverlening

WO sociale wetenschappen

$\mathrm{HO}$ medisch

HBO verpleegkunde

HBO (fysio)therapie

WO (dier)geneeskunde

\begin{tabular}{|c|c|}
\hline gemiddeld & sterk stijgend \\
\hline $\begin{array}{l}\text { gemidael } \\
\text { gemiddeld }\end{array}$ & sterk stijgend \\
\hline gemiddeld & 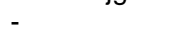 \\
\hline gemiddeld & - \\
\hline $\begin{array}{l}\text { laag } \\
\text { gemiddeld }\end{array}$ & sterk dalend \\
\hline laag & - \\
\hline laag & - \\
\hline laag & sterk stijgend \\
\hline gemiddeld & 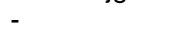 \\
\hline laag & sterk dalend \\
\hline gemiddeld & - \\
\hline gemiddeld & sterk dalend \\
\hline gemiddeld & - \\
\hline laag & - \\
\hline gemiddeld & constant \\
\hline erg laag & sterk dalend \\
\hline laag & - \\
\hline erg laag & sterk dalend \\
\hline $\begin{array}{l}\text { erg laag } \\
\text { laag }\end{array}$ & $\begin{array}{l}\text { sterk stijgend } \\
\text { constant }\end{array}$ \\
\hline
\end{tabular}


Tabel 12.2 (vervolg)

Percentage werkenden dat regelmatig wordt geconfronteerd met lawaai tijdens het werk, gemiddelde 20012002

$\% \quad$ typering trend $2000-2002$

Beroepen

Pedagogische beroepen

Culturele beroepen

Technische, ambachts- en industrieberoepen

Medische en paramedische beroepen

Verpleeghulpen en leerling-verpleegkundigen

Verplegenden en doktersassistenten

Therapeuten en verpleegkundigen

Artsen

Apothekersassistenten en medisch laboranten

Medisch analisten

Economisch-administratieve beroepen

Receptionisten en administratieve employés

Boekhouders en secretaresses

Managers

Medisch secretaresses

Sociaal-culturele beroepen

Activiteitenbegeleiders en medewerkers arbeidsbemiddeling

Medewerkers sociaal-cultureel werk en personeel en arbeid

Verzorgende en dienstverlenende beroepen

Interieurverzorgers

Hulpkrachten horeca en verzorging

Ziekenverzorgenden

Verzorgend personeel

gemiddeld constant

laag

hoog

laag

laag

gemiddeld sterk stijgend

laag

laag

erg laag

gemiddeld

laag

gemiddeld

erg laag

gemiddeld

erg laag

laag

gemiddeld

laag

gemiddeld

gemiddeld

laag

laag

gemiddeld

sterk dalend

sterk stijgend

sterk dalend

sterk stijgend

sterk stijgend

-

sterk dalend

sterk dalend

sterk dalend

sterk dalend

sterk stijgend

constant

sterk dalend

Specifieke groepen werkenden

Vrouwen

$4 \quad$ gemiddeld

5 gemiddeld
Jongeren

Ouderen

Allochtonen

4 gemiddeld

6 gemiddeld

Totaal

4 gemiddeld

sterk dalend

-

$-$

Bron: ROA/CBS 


\section{Kwartaire diensten}

Tabel 12.3

Percentage werkenden dat regelmatig werkt met trillende apparaten, gemiddelde 2001-2002

\begin{tabular}{|c|c|c|c|}
\hline & $\%$ & typering & trend $2000-2002$ \\
\hline \multicolumn{4}{|l|}{ Opleidingen } \\
\hline Basisonderwijs & 3 & gemiddeld & constant \\
\hline VMBO theorie & 2 & laag & sterk dalend \\
\hline VMBO economie & 4 & gemiddeld & - \\
\hline VMBO verzorging & 1 & laag & - \\
\hline VMBO (uiterlijke) verzorging & 1 & laag & - \\
\hline HAVO/VWO & 3 & gemiddeld & - \\
\hline MBO natuur en techniek & 11 & gemiddeld & dalend \\
\hline MBO economie & 2 & laag & - \\
\hline MBO administratie & 0 & erg laag & sterk dalend \\
\hline MBO secretariaat & 2 & laag & - \\
\hline MBO dienstverlening en gezondheidszorg & 1 & laag & sterk dalend \\
\hline MBO dokters-, tandarts- en dierenartsassistent & 4 & gemiddeld & - \\
\hline MBO verpleging & 2 & laag & - \\
\hline MBO sociaal-cultureel & 0 & erg laag & sterk stijgend \\
\hline MBO verzorging & 1 & laag & - \\
\hline $\mathrm{HO}$ natuur en techniek & 8 & gemiddeld & sterk stijgend \\
\hline HO onderwijs en sociaal-cultureel & 0 & erg laag & constant \\
\hline HO medisch & 3 & gemiddeld & - \\
\hline HBO verpleegkunde & 1 & laag & - \\
\hline HBO (fysio)therapie & 10 & gemiddeld & sterk stijgend \\
\hline WO (dier)geneeskunde & 1 & laag & sterk dalend \\
\hline \multicolumn{4}{|l|}{ Beroepen } \\
\hline Pedagogische beroepen & 2 & laag & sterk stijgend \\
\hline Culturele beroepen & 0 & erg laag & stijgend \\
\hline Technische, ambachts- en industrieberoepen & 14 & hoog & - \\
\hline Medische en paramedische beroepen & 3 & gemiddeld & sterk dalend \\
\hline Verpleeghulpen en leerling-verpleegkundigen & 1 & laag & sterk dalend \\
\hline Verplegenden en doktersassistenten & 4 & gemiddeld & sterk dalend \\
\hline Therapeuten en verpleegkundigen & 2 & laag & sterk dalend \\
\hline Artsen & 4 & gemiddeld & sterk stijgend \\
\hline Apothekersassistenten en medisch laboranten & 7 & gemiddeld & sterk dalend \\
\hline Medisch analisten & 7 & gemiddeld & sterk dalend \\
\hline Economisch-administratieve beroepen & 0 & erg laag & sterk dalend \\
\hline Receptionisten en administratieve employés & 0 & erg laag & sterk dalend \\
\hline Boekhouders en secretaresses & 0 & erg laag & sterk dalend \\
\hline Managers & 2 & laag & sterk stijgend \\
\hline Sociaal-culturele beroepen & 0 & erg laag & sterk stijgend \\
\hline Medewerkers sociaal-cultureel werk en personeel en arbeid & 0 & erg laag & stijgend \\
\hline Verzorgende en dienstverlenende beroepen & 1 & laag & sterk dalend \\
\hline Interieurverzorgers & 3 & gemiddeld & - \\
\hline Hulpkrachten horeca en verzorging & 2 & laag & - \\
\hline Ziekenverzorgenden & 0 & erg laag & stijgend \\
\hline Verzorgend personeel & 1 & laag & - \\
\hline \multicolumn{4}{|l|}{ Specifieke groepen werkenden } \\
\hline Vrouwen & 1 & laag & sterk dalend \\
\hline Jongeren & 2 & laag & sterk dalend \\
\hline Ouderen & 2 & laag & sterk dalend \\
\hline Allochtonen & 2 & laag & constant \\
\hline Totaal & 2 & laag & sterk dalend \\
\hline
\end{tabular}

Bron: ROA/CBS 
Tabel 12.4

Percentage werkenden dat regelmatig kracht moet zetten tijdens het werk, gemiddelde 2001-2002

\begin{tabular}{|c|c|c|c|}
\hline & $\%$ & typering & trend 2000-2002 \\
\hline \multicolumn{4}{|l|}{ Opleidingen } \\
\hline Basisonderwijs & 40 & hoog & - \\
\hline VMBO theorie & 34 & hoog & sterk stijgend \\
\hline VMBO natuur en techniek & 38 & hoog & - \\
\hline VMBO economie & 34 & hoog & - \\
\hline VMBO administratie, handel en mode & 36 & hoog & sterk stijgend \\
\hline VMBO verzorging & 45 & hoog & sterk dalend \\
\hline VMBO (uiterlijke) verzorging & 45 & hoog & sterk dalend \\
\hline HAVO/VWO & 23 & gemiddeld & sterk stijgend \\
\hline MBO natuur en techniek & 25 & gemiddeld & - \\
\hline MBO economie & 15 & gemiddeld & constant \\
\hline MBO administratie & 15 & gemiddeld & - \\
\hline MBO handel & 20 & gemiddeld & sterk dalend \\
\hline MBO secretariaat & 13 & gemiddeld & - \\
\hline MBO dienstverlening en gezondheidszorg & 49 & erg hoog & dalend \\
\hline MBO dokters-, tandarts- en dierenartsassistent & 8 & gemiddeld & sterk dalend \\
\hline MBO verpleging & 51 & erg hoog & dalend \\
\hline MBO sociaal-cultureel & 39 & hoog & stijgend \\
\hline MBO verzorging & 61 & erg hoog & dalend \\
\hline MBO horeca & 50 & erg hoog & constant \\
\hline MBO beweging en therapie & 30 & gemiddeld & constant \\
\hline HO natuur en techniek & 3 & laag & - \\
\hline $\mathrm{HO}$ economie & 4 & gemiddeld & constant \\
\hline HO onderwijs en sociaal-cultureel & 11 & gemiddeld & - \\
\hline HBO lerarenopleiding basisonderwijs & 22 & gemiddeld & - \\
\hline HBO maatschappelijk werk en hulpverlening & 15 & gemiddeld & - \\
\hline WO sociale wetenschappen & 3 & laag & - \\
\hline HO medisch & 31 & gemiddeld & constant \\
\hline HBO verpleegkunde & 38 & hoog & - \\
\hline HBO (fysio)therapie & 42 & hoog & - \\
\hline HBO radiologie & 50 & erg hoog & sterk dalend \\
\hline WO (dier)geneeskunde & 11 & gemiddeld & - \\
\hline \multicolumn{4}{|l|}{ Beroepen } \\
\hline Pedagogische beroepen & 6 & gemiddeld & - \\
\hline Culturele beroepen & 9 & gemiddeld & - \\
\hline Technische, ambachts- en industrieberoepen & 34 & hoog & - \\
\hline Productiemedewerkers & 48 & erg hoog & sterk stijgend \\
\hline Transportberoepen & 70 & erg hoog & sterk stijgend \\
\hline Medische en paramedische beroepen & 38 & hoog & dalend \\
\hline Verpleeghulpen en leerling-verpleegkundigen & 70 & erg hoog & - \\
\hline Verplegenden en doktersassistenten & 44 & hoog & constant \\
\hline Therapeuten en verpleegkundigen & 46 & hoog & stijgend \\
\hline Artsen & 8 & gemiddeld & sterk dalend \\
\hline Apothekersassistenten en medisch laboranten & 7 & gemiddeld & sterk dalend \\
\hline Medisch analisten & 23 & gemiddeld & sterk dalend \\
\hline Economisch-administratieve beroepen & 6 & gemiddeld & - \\
\hline Receptionisten en administratieve employés & 6 & gemiddeld & sterk stijgend \\
\hline Boekhouders en secretaresses & 2 & laag & sterk stijgend \\
\hline Managers & 19 & gemiddeld & - \\
\hline Medisch secretaresses & 2 & laag & - \\
\hline Sociaal-culturele beroepen & 13 & gemiddeld & constant \\
\hline Activiteitenbegeleiders en medewerkers arbeidsbemiddeling & 22 & gemiddeld & constant \\
\hline Medewerkers sociaal-cultureel werk en personeel en arbeid & 7 & gemiddeld & - \\
\hline Verzorgende en dienstverlenende beroepen & 55 & erg hoog & constant \\
\hline Interieurverzorgers & 41 & hoog & constant \\
\hline Hulpkrachten horeca en verzorging & 44 & hoog & sterk dalend \\
\hline Ziekenverzorgenden & 73 & erg hoog & constant \\
\hline
\end{tabular}




\section{Kwartaire diensten}

Tabel 12.4 (vervolg)

Percentage werkenden dat regelmatig kracht moet zetten tijdens het werk, gemiddelde 2001-2002

\begin{tabular}{lccc}
\hline & $\%$ & typering & trend 2000-2002 \\
\hline Verzorgend personeel & 57 & erg hoog & constant \\
Specifieke groepen werkenden & & & \\
Vrouwen & 36 & hoog & dalend \\
Jongeren & 41 & hoog & stijgend \\
Ouderen & 27 & gemiddeld stijgend \\
Allochtonen & 26 & gemiddeld sterk dalend \\
Totaal & 32 & hoog & constant
\end{tabular}

Bron: ROA/CBS 
Tabel 12.5

Percentage werkenden dat regelmatig onder hoge tijdsdruk werkt, gemiddelde 2001-2002

\begin{tabular}{|c|c|c|c|}
\hline & $\%$ & typering & trend $2000-2002$ \\
\hline \multicolumn{4}{|l|}{ Opleidingen } \\
\hline Basisonderwijs & 21 & laag & constant \\
\hline VMBO theorie & 29 & gemiddeld & - \\
\hline VMBO natuur en techniek & 22 & laag & - \\
\hline VMBO economie & 19 & laag & sterk dalend \\
\hline VMBO verzorging & 27 & gemiddeld & dalend \\
\hline VMBO (uiterlijke) verzorging & 27 & gemiddeld & dalend \\
\hline HAVO/VWO & 28 & gemiddeld & constant \\
\hline MBO natuur en techniek & 22 & laag & sterk dalend \\
\hline MBO economie & 32 & gemiddeld & constant \\
\hline MBO administratie & 35 & gemiddeld & - \\
\hline MBO handel & 22 & laag & - \\
\hline MBO secretariaat & 32 & gemiddeld & - \\
\hline MBO bedrijfskunde & 44 & erg hoog & - \\
\hline MBO dienstverlening en gezondheidszorg & 36 & gemiddeld & sterk dalend \\
\hline MBO dokters-, tandarts- en dierenartsassistent & 35 & gemiddeld & dalend \\
\hline MBO verpleging & 40 & hoog & dalend \\
\hline MBO sociaal-cultureel & 22 & laag & sterk dalend \\
\hline MBO verzorging & 38 & gemiddeld & sterk dalend \\
\hline MBO horeca & 44 & hoog & stijgend \\
\hline HO natuur en techniek & 33 & gemiddeld & - \\
\hline HBO laboratorium & 32 & gemiddeld & constant \\
\hline WO wiskunde en natuurwetenschappen & 34 & gemiddeld & sterk dalend \\
\hline $\mathrm{HO}$ economie & 35 & gemiddeld & dalend \\
\hline HBO bedrijfskunde & 35 & gemiddeld & sterk dalend \\
\hline $\mathrm{HO}$ onderwijs en sociaal-cultureel & 36 & gemiddeld & constant \\
\hline HBO communicatie en journalistiek & 59 & erg hoog & - \\
\hline HBO maatschappelijk werk en hulpverlening & 35 & gemiddeld & stijgend \\
\hline HBO personeel en arbeid & 50 & erg hoog & - \\
\hline HBO uitvoerende en beeldende kunsten & 46 & erg hoog & - \\
\hline WO sociale wetenschappen & 41 & hoog & dalend \\
\hline $\mathrm{HO}$ medisch & 45 & erg hoog & constant \\
\hline $\mathrm{HBO}$ verpleegkunde & 46 & erg hoog & dalend \\
\hline HBO (fysio)therapie & 27 & gemiddeld & - \\
\hline $\mathrm{HBO}$ radiologie & 47 & erg hoog & - \\
\hline WO (dier)geneeskunde & 56 & erg hoog & constant \\
\hline \multicolumn{4}{|l|}{ Beroepen } \\
\hline Pedagogische beroepen & 30 & gemiddeld & sterk dalend \\
\hline Onderwijskundigen en pedagogen & 48 & erg hoog & - \\
\hline Culturele beroepen & 51 & erg hoog & sterk stijgend \\
\hline Kunstenaars & 57 & erg hoog & stijgend \\
\hline Journalisten & 70 & erg hoog & stijgend \\
\hline Technische, ambachts- en industrieberoepen & 27 & gemiddeld & constant \\
\hline Medische en paramedische beroepen & 40 & hoog & dalend \\
\hline Verpleeghulpen en leerling-verpleegkundigen & 43 & hoog & - \\
\hline Verplegenden en doktersassistenten & 40 & hoog & dalend \\
\hline Therapeuten en verpleegkundigen & 36 & gemiddeld & constant \\
\hline Artsen & 50 & erg hoog & dalend \\
\hline Apothekersassistenten en medisch laboranten & 28 & gemiddeld & sterk dalend \\
\hline Medisch analisten & 39 & hoog & constant \\
\hline Afdelingshoofden zorginstelling & 46 & erg hoog & dalend \\
\hline Economisch-administratieve beroepen & 34 & gemiddeld & constant \\
\hline
\end{tabular}


Kwartaire diensten

Tabel 12.5 (vervolg)

Percentage werkenden dat regelmatig onder hoge tijdsdruk werkt, gemiddelde 2001-2002

\begin{tabular}{|c|c|c|c|}
\hline & $\%$ & typering & trend $2000-2002$ \\
\hline $\begin{array}{l}\text { Receptionisten en administratieve employés } \\
\text { Boekhouders en secretaresses } \\
\text { Assistent accountants } \\
\text { Managers } \\
\text { Medisch secretaresses } \\
\text { Informatica beroepen } \\
\text { Sociaal-culturele beroepen } \\
\text { Activiteitenbegeleiders en medewerkers arbeidsbemiddeling } \\
\text { Medewerkers sociaal-cultureel werk en personeel en arbeid } \\
\text { Hoofden sociaal-cultureel werk en personeel en arbeid } \\
\text { Sociaal-wetenschappelijk onderzoekers } \\
\text { Verzorgende en dienstverlenende beroepen } \\
\text { Interieurverzorgers } \\
\text { Hulpkrachten horeca en verzorging } \\
\text { Ziekenverzorgenden } \\
\text { Verzorgend personeel }\end{array}$ & $\begin{array}{l}22 \\
27 \\
38 \\
56 \\
30 \\
28 \\
30 \\
20 \\
36 \\
50 \\
32 \\
30 \\
26 \\
22 \\
45 \\
28\end{array}$ & $\begin{array}{l}\text { laag } \\
\text { gemiddeld } \\
\text { gemiddeld } \\
\text { erg hoog } \\
\text { gemiddeld } \\
\text { gemiddeld } \\
\text { gemiddeld } \\
\text { laag } \\
\text { gemiddeld } \\
\text { erg hoog } \\
\text { gemiddeld } \\
\text { gemiddeld } \\
\text { gemiddeld } \\
\text { laag } \\
\text { erg hoog } \\
\text { gemiddeld }\end{array}$ & $\begin{array}{l}\text { - } \\
\text { dalend } \\
\text { constant } \\
\text { dalend } \\
\text { sterk dalend } \\
\text { dalend } \\
\text { sterk dalend } \\
\text { dalend } \\
\text { stijgend } \\
\text { sterk dalend } \\
\text { sterk dalend } \\
\text { dalend } \\
\text { sterk dalend } \\
\text { sterk dalend } \\
\text { sterk dalend }\end{array}$ \\
\hline $\begin{array}{l}\text { Specifieke groepen werkenden } \\
\text { Vrouwen } \\
\text { Jongeren } \\
\text { Ouderen } \\
\text { Allochtonen }\end{array}$ & $\begin{array}{l}33 \\
29 \\
37 \\
29\end{array}$ & $\begin{array}{l}\text { gemiddeld } \\
\text { gemiddeld } \\
\text { gemiddeld } \\
\text { gemiddeld }\end{array}$ & $\begin{array}{l}\text { dalend } \\
\text { dalend } \\
\text { constant } \\
\text { dalend }\end{array}$ \\
\hline Totaal & 34 & gemiddeld & dalend \\
\hline
\end{tabular}

Bron: ROA/CBS 
Tabel 12.6

Percentage werkenden dat regelmatig beeldschermwerk verricht, gemiddelde 2001-2002

\begin{tabular}{|c|c|c|c|}
\hline & $\%$ & typering & trend 2000-2002 \\
\hline \multicolumn{4}{|l|}{ Opleidingen } \\
\hline Basisonderwijs & 7 & erg laag & sterk dalend \\
\hline VMBO theorie & 40 & gemiddeld & sterk stijgend \\
\hline VMBO economie & 21 & laag & - \\
\hline VMBO administratie, handel en mode & 20 & laag & sterk dalend \\
\hline VMBO verzorging & 9 & laag & sterk stijgend \\
\hline VMBO (uiterlijke) verzorging & 9 & laag & sterk stijgend \\
\hline HAVO/VWO & 58 & gemiddeld & constant \\
\hline MBO natuur en techniek & 45 & gemiddeld & sterk stijgend \\
\hline MBO laboratorium & 50 & gemiddeld & - \\
\hline MBO economie & 68 & gemiddeld & - \\
\hline MBO administratie & 75 & gemiddeld & constant \\
\hline MBO handel & 42 & gemiddeld & sterk stijgend \\
\hline MBO secretariaat & 78 & hoog & constant \\
\hline MBO bedrijfskunde & 77 & hoog & sterk stijgend \\
\hline MBO dienstverlening en gezondheidszorg & 19 & laag & sterk stijgend \\
\hline MBO dokters-, tandarts- en dierenartsassistent & 64 & gemiddeld & - \\
\hline MBO apothekersassistent & 76 & gemiddeld & - \\
\hline MBO verpleging & 20 & laag & sterk stijgend \\
\hline MBO sociaal-cultureel & 17 & laag & sterk dalend \\
\hline MBO verzorging & 11 & laag & sterk stijgend \\
\hline MBO horeca & 42 & gemiddeld & sterk stijgend \\
\hline HO natuur en techniek & 69 & gemiddeld & sterk stijgend \\
\hline HBO laboratorium & 51 & gemiddeld & sterk stijgend \\
\hline WO landbouw en milieukunde & 100 & erg hoog & sterk stijgend \\
\hline WO wiskunde en natuurwetenschappen & 89 & hoog & sterk stijgend \\
\hline HO economie & 80 & hoog & - \\
\hline HBO secretariaat & 85 & hoog & dalend \\
\hline HBO bedrijfskunde & 71 & gemiddeld & - \\
\hline WO econom(etr)ie & 77 & hoog & - \\
\hline WO bedrijfskunde & 63 & gemiddeld & constant \\
\hline WO rechten en bestuurskunde & 96 & erg hoog & sterk stijgend \\
\hline $\mathrm{HO}$ onderwijs en sociaal-cultureel & 48 & gemiddeld & stijgend \\
\hline HBO maatschappelijk werk en hulpverlening & 46 & gemiddeld & sterk stijgend \\
\hline HBO personeel en arbeid & 88 & hoog & stijgend \\
\hline WO letteren & 81 & hoog & sterk stijgend \\
\hline WO sociale wetenschappen & 65 & gemiddeld & sterk stijgend \\
\hline $\mathrm{HO}$ medisch & 34 & gemiddeld & sterk stijgend \\
\hline HBO verpleegkunde & 30 & gemiddeld & sterk stijgend \\
\hline HBO (fysio)therapie & 21 & laag & sterk stijgend \\
\hline HBO radiologie & 69 & gemiddeld & - \\
\hline WO (dier)geneeskunde & 35 & gemiddeld & sterk stijgend \\
\hline \multicolumn{4}{|l|}{ Beroepen } \\
\hline Pedagogische beroepen & 35 & gemiddeld & - \\
\hline Culturele beroepen & 69 & gemiddeld & sterk stijgend \\
\hline Kunstenaars & 63 & gemiddeld & sterk stijgend \\
\hline Journalisten & 88 & hoog & - \\
\hline Technische, ambachts- en industrieberoepen & 32 & gemiddeld & sterk stijgend \\
\hline Natuurwetenschappers & 61 & gemiddeld & constant \\
\hline Medische en paramedische beroepen & 29 & gemiddeld & sterk stijgend \\
\hline Verpleeghulpen en leerling-verpleegkundigen & 5 & erg laag & sterk stijgend \\
\hline
\end{tabular}


Kwartaire diensten

Tabel 12.6 (vervolg)

Percentage werkenden dat regelmatig beeldschermwerk verricht, gemiddelde 2001-2002

\begin{tabular}{|c|c|c|c|}
\hline & $\%$ & typering & trend $2000-2002$ \\
\hline Verplegenden en doktersassistenten & 30 & gemiddeld & - \\
\hline Therapeuten en verpleegkundigen & 16 & laag & sterk stijgend \\
\hline Artsen & 39 & gemiddeld & sterk stijgend \\
\hline Apothekersassistenten en medisch laboranten & 55 & gemiddeld & sterk stijgend \\
\hline Medisch analisten & 64 & gemiddeld & sterk stijgend \\
\hline Apothekers & 74 & gemiddeld & constant \\
\hline Afdelingshoofden zorginstelling & 66 & gemiddeld & sterk stijgend \\
\hline Economisch-administratieve beroepen & 81 & hoog & constant \\
\hline Productieplanners & 85 & hoog & dalend \\
\hline Organisatie-adviseurs & 72 & gemiddeld & constant \\
\hline Receptionisten en administratieve employés & 80 & hoog & constant \\
\hline Boekhouders en secretaresses & 96 & erg hoog & constant \\
\hline Assistent accountants & 98 & erg hoog & sterk stijgend \\
\hline Commercieel employés & 87 & hoog & - \\
\hline Commercieel medewerkers & 85 & hoog & - \\
\hline Juristen & 92 & erg hoog & constant \\
\hline Leidinggevenden & 59 & gemiddeld & - \\
\hline Managers & 48 & gemiddeld & - \\
\hline Medisch secretaresses & 90 & hoog & constant \\
\hline Informatica beroepen & 98 & erg hoog & stijgend \\
\hline Programmeurs & 92 & erg hoog & stijgend \\
\hline Systeemanalisten & 100 & erg hoog & constant \\
\hline Sociaal-culturele beroepen & 37 & gemiddeld & sterk stijgend \\
\hline Activiteitenbegeleiders en medewerkers arbeidsbemiddeling & 22 & laag & - \\
\hline Medewerkers sociaal-cultureel werk en personeel en arbeid & 49 & gemiddeld & stijgend \\
\hline Sociaal-wetenschappelijk onderzoekers & 53 & gemiddeld & sterk stijgend \\
\hline Verzorgende en dienstverlenende beroepen & 5 & erg laag & stijgend \\
\hline Interieurverzorgers & 0 & erg laag & - \\
\hline Hulpkrachten horeca en verzorging & 1 & erg laag & sterk dalend \\
\hline Ziekenverzorgenden & 5 & erg laag & sterk stijgend \\
\hline Verzorgend personeel & 7 & erg laag & sterk stijgend \\
\hline \multicolumn{4}{|l|}{ Specifieke groepen werkenden } \\
\hline Vrouwen & 30 & gemiddeld & stijgend \\
\hline Jongeren & 25 & gemiddeld & constant \\
\hline Ouderen & 37 & gemiddeld & sterk stijgend \\
\hline Allochtonen & 30 & gemiddeld & stijgend \\
\hline Totaal & 35 & gemiddeld & stijgend \\
\hline
\end{tabular}

Bron: ROA/CBS 
Kwartaire diensten

Tabel 12.7

Percentage werkenden dat deelneemt aan scholingstrajecten korter dan 6 maanden, gemiddelde 2001-2002

$\% \quad$ typering

Opleidingen

Basisonderwijs

VMBO theorie

VMBO economie

VMBO verzorging

VMBO (uiterlijke) verzorging

HAVO/VWO

MBO natuur en techniek

$\mathrm{MBO}$ economie

MBO administratie

MBO secretariaat

MBO dienstverlening en gezondheidszorg

MBO dokters-, tandarts- en dierenartsassistent

$M B O$ verpleging

MBO sociaal-cultureel

$M B O$ verzorging

$\mathrm{HO}$ natuur en techniek

$\mathrm{HO}$ economie

$\mathrm{HO}$ onderwijs en sociaal-culturee

HBO maatschappelijk werk en hulpverlening

WO sociale wetenschappen

$\mathrm{HO}$ medisch

HBO verpleegkunde

HBO (fysio)therapie

WO (dier)geneeskunde

\section{Beroepen}

Pedagogische beroepen

Culturele beroepen

Technische, ambachts- en industrieberoepen

Medische en paramedische beroepen

Verpleeghulpen en leerling-verpleegkundigen

Verplegenden en doktersassistenten

Therapeuten en verpleegkundigen

Artsen

Apothekersassistenten en medisch laboranten

Medisch analisten

Economisch-administratieve beroepen

Receptionisten en administratieve employés

Boekhouders en secretaresses

Managers

Medisch secretaresses

Sociaal-culturele beroepen

Activiteitenbegeleiders en medewerkers arbeidsbemiddeling

Medewerkers sociaal-cultureel werk en personeel en arbeid

Verzorgende en dienstverlenende beroepen

Interieurverzorgers

Hulpkrachten horeca en verzorging

Ziekenverzorgenden

Verzorgend personeel trend $2000-2002$

sterk dalend

laag

laag

gemiddeld

gemiddeld

gemiddeld

laag

hoog

gemiddeld

hoog

gemiddeld

gemiddeld

laag

gemiddeld

gemiddeld

gemiddeld

laag

gemiddeld

gemiddeld

gemiddeld

gemiddeld

gemiddeld

gemiddeld

hoog

laag

constant

sterk stijgend

stijgend

constant

constant

sterk dalend

sterk stijgend

sterk dalend

sterk dalend

constant

dalend

sterk stijgend

constant

sterk dalend

$\begin{array}{ll}\text { hoog } & - \\ \text { laag } & - \\ \text { gemiddeld } & - \\ \text { gemiddeld } & \text { dalend } \\ \text { laag } & - \\ \text { gemiddeld } & \text { sterk stijgend } \\ \text { hoog } & \text { sterk stijgend } \\ \text { laag } & \text { sterk dalend } \\ \text { gemiddeld } & \text { sterk dalend } \\ \text { laag } & \text { sterk stijgend } \\ \text { gemiddeld } & - \\ \text { gemiddeld } & \text { sterk dalend } \\ \text { gemiddeld } & \text { sterk stijgend } \\ \text { hoog } & - \\ \text { laag } & \text { sterk dalend } \\ \text { gemiddeld } & \text { sterk dalend } \\ \text { gemiddeld } & \text { sterk dalend } \\ \text { gemiddeld } & - \\ \text { gemiddeld } & \text { sterk stijgend } \\ \text { erg laag } & - \\ \text { laag } & \text { sterk dalend } \\ \text { gemiddeld } & \text { sterk stijgend } \\ \text { gemiddeld } & \text { sterk stijgend }\end{array}$




\section{Kwartaire diensten}

Tabel 12.7 (vervolg)

Percentage werkenden dat deelneemt aan scholingstrajecten korter dan 6 maanden, gemiddelde 2001-2002

$$
\% \quad \text { typering trend 2000-2002 }
$$

Specifieke groepen werkenden

Vrouwen

Jongeren

Ouderen

Allochtonen

4 gemiddeld dalend

Totaal

3 laag sterk dalend

4 gemiddeld sterk stijgend

4 gemiddeld

Bron: ROA/CBS 
Tabel 12.8

Percentage werkenden dat deelneemt aan scholingstrajecten van 6 maanden of langer, gemiddelde 20012002

\section{Opleidingen}

Basisonderwijs

VMBO theorie

VMBO economie

VMBO verzorging

VMBO (uiterlijke) verzorging

$\mathrm{HAVO} / \mathrm{VWO}$

MBO natuur en techniek

$\mathrm{MBO}$ economie

MBO administratie

MBO secretariaat

MBO dienstverlening en gezondheidszorg

MBO dokters-, tandarts- en dierenartsassistent

$\mathrm{MBO}$ verpleging

MBO sociaal-cultureel

$\mathrm{MBO}$ verzorging

$\mathrm{HO}$ natuur en techniek

$\mathrm{HO}$ economie

$\mathrm{HO}$ onderwijs en sociaal-cultureel

HBO maatschappelijk werk en hulpverlening

WO sociale wetenschappen

$\mathrm{HO}$ medisch

$\mathrm{HBO}$ verpleegkunde

$\mathrm{HBO}$ (fysio)therapie

WO (dier)geneeskunde

Beroepen

Pedagogische beroepen

Culturele beroepen

Technische, ambachts- en industrieberoepen

Medische en paramedische beroepen

Verpleeghulpen en leerling-verpleegkundigen

Verplegenden en doktersassistenten

Therapeuten en verpleegkundigen

Artsen

Apothekersassistenten en medisch laboranten

Medisch analisten

Economisch-administratieve beroepen

Receptionisten en administratieve employés

Boekhouders en secretaresses

Managers

Medisch secretaresses

Sociaal-culturele beroepen

Activiteitenbegeleiders en medewerkers arbeidsbemiddeling

Medewerkers sociaal-cultureel werk en personeel en arbeid

Verzorgende en dienstverlenende beroepen

Interieurverzorgers

Hulpkrachten horeca en verzorging

Ziekenverzorgenden

Verzorgend personeel laag

erg hoog

gemiddeld

gemiddeld

gemiddeld

erg hoog

gemiddeld

gemiddeld

gemiddeld

laag

gemiddeld

erg laag

gemiddeld

hoog

gemiddeld

laag

gemiddeld

gemiddeld

gemiddeld

gemiddeld

hoog

gemiddeld

hoog

erg hoog

sterk stijgend

sterk stijgend

sterk stijgend

stijgend

stijgend

constant

sterk dalend

constant

sterk dalend

constant

constant

stijgend

sterk dalend

sterk dalend

stijgend

sterk stijgend

dalend

sterk dalend

constant

sterk stijgend

sterk stijgend

sterk dalend

constant

sterk stijgend

dalend

sterk dalend

constant

sterk stijgend

-

dalend

constant

sterk dalend

sterk stijgend

constant

sterk stijgend

hoog

hoog

gemiddeld

gemiddeld

laag

gemiddeld

gemiddeld

gemiddeld sterk stijgend

constant sterk stijgend 


\section{Kwartaire diensten}

Tabel 12.8 (vervolg)

Percentage werkenden dat deelneemt aan scholingstrajecten van 6 maanden of langer, gemiddelde 20012002

$\% \quad$ typering trend 2000-2002

Specifieke groepen werkenden

Vrouwen

Jongeren

Ouderen

Allochtonen

stijgend

28 erg hoog

stijgend

Totaal

21 erg hoog sterk stijgend

Bron: ROA/CBS

14 gemiddeld constant

Tabel 12.9

Doelgroepen voor het scholingsbeleid en risicofactoren

\begin{tabular}{ll} 
Doelgroepen & risicofactor(en) \\
\hline $\begin{array}{l}\text { Journalisten } \\
\text { Kunstenaars }\end{array}$ & $\begin{array}{l}\text { tijdsdruk, agressief gedrag van klanten } \\
\text { tijdsdruk, agressief gedrag van klanten }\end{array}$ \\
\hline
\end{tabular}


13. Overheid en onderwijs 

Tabel 13.1

Kernindicatoren

\section{Arbeidsomstandigheden}

Belastende arbeidsomstandigheden

$\%$ werknemers dat regelmatig geconfronteerd wordt met:

$\begin{array}{rrl}2000 & 2001 / 2002 & \text { typering } \\ \% & \% & \\ 7 & 6 & \text { gemiddeld } \\ 3 & 3 & \text { gemiddeld } \\ 8 & 7 & \text { gemiddeld } \\ 33 & 31 & \text { gemiddeld } \\ 56 & 57 & \text { gemiddeld }\end{array}$

Technologische en organisatorische ontwikkelingen

Organisatorische ontwikkelingen

bedrijven

Lawaai

Trilling

Kracht zetten

Tijdsdruk

Beeldschermwerk

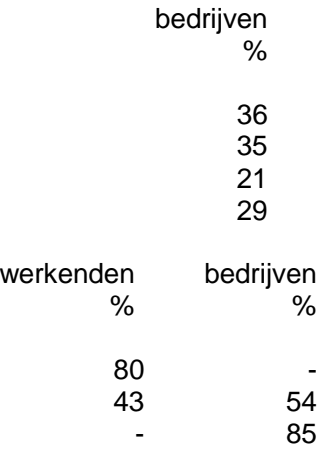

Vernieuwingen in het productieproces, 1999-2001

Automatisering, 2002

jaarlijks \%

Ingrijpende productverandering, 2000-2002

Veranderingen in positie, 2000-2002

Interne reorganisaties, 2000-2002

Verschuivingen in de werkgelegenheid

Verwachte werkgelegenheidsontwikkeling, 2003-2008

\section{Scholingsdeelname}

2000 2001/ typering 2002

$\% \quad \%$

$76 \quad$ hoog

1314 gemiddeld

Deelname aan opleidingstrajecten korter dan 6 maanden (momentopname)

Deelname aan opleidingstrajecten van 6 maanden of langer (momentopname)

Bron: ROA/CBS/OSA 


\section{Risicoprofiel}

Figuur 13.1

Sectoraal risicoprofiel

\section{Overheid en onderwijs}

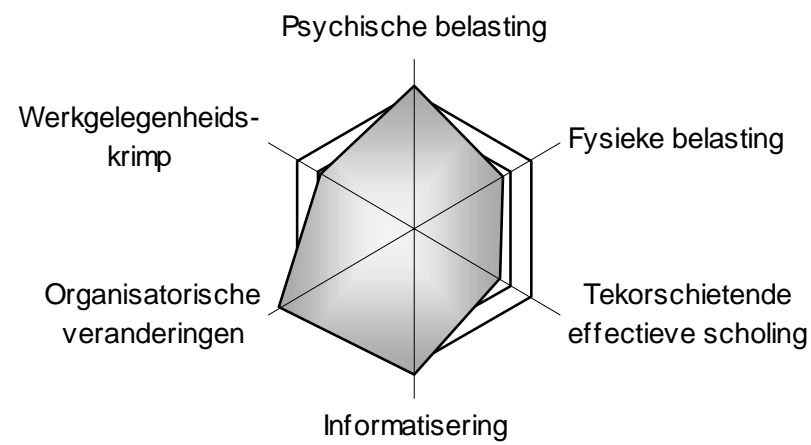

Tabel 13.2

Percentage werkenden dat regelmatig wordt geconfronteerd met lawaai tijdens het werk, gemiddelde 20012002

Opleidingen

Basisonderwijs

VMBO theorie

VMBO natuur en techniek

VMBO economie

$\mathrm{HAVO} / \mathrm{VWO}$

MBO natuur en techniek

MBO openbare orde en veiligheid

MBO economie

MBO administratie

MBO handel

MBO secretariaat

MBO dienstverlening en gezondheidszorg

MBO sociaal-cultureel

$\mathrm{HO}$ natuur en techniek

WO wiskunde en natuurwetenschappen

$\mathrm{HO}$ economie

WO rechten en bestuurskunde

$\mathrm{HO}$ onderwijs en sociaal-cultureel

HBO lerarenopleiding basisonderwijs

HBO lerarenopleiding talen

HBO lerarenopleiding natuur en techniek

HBO lerarenopleiding economie en maatschappij

HBO lerarenopleiding lichamelijke opvoeding

HBO lerarenopleiding expressie

HBO maatschappelijk werk en hulpverlening

WO letteren

$\begin{array}{ll}\text { gemiddeld } & - \\ \text { laag } & \text { sterk stijgend } \\ \text { gemiddeld } & \text { sterk dalend } \\ \text { hoog } & - \\ \text { gemiddeld } & \text { constant } \\ \text { gemiddeld } & \text { constant } \\ \text { hoog } & \text { sterk stijgend } \\ \text { gemiddeld } & \text { sterk stijgend } \\ \text { erg laag } & - \\ \text { gemiddeld } & - \\ \text { erg laag } & - \\ \text { gemiddeld } & - \\ \text { gemiddeld } & \text { dalend } \\ \text { laag } & \text { sterk dalend } \\ \text { gemiddeld } & \text { sterk dalend } \\ \text { erg laag } & - \\ \text { erg laag } & \text { sterk dalend } \\ \text { gemiddeld } & \text { constant } \\ \text { gemiddeld } & \text { sterk dalend } \\ \text { hoog } & \text { sterk stijgend } \\ \text { hoog } & \text { sterk dalend } \\ \text { laag } & - \\ \text { erg hoog } & \text { sterk stijgend } \\ \text { hoog } & \text { sterk stijgend } \\ \text { laag } & \text { sterk dalend } \\ \text { laag } & \text { constant } \\ & \end{array}$


Tabel 13.2 (vervolg)

Percentage werkenden dat regelmatig wordt geconfronteerd met lawaai tijdens het werk, gemiddelde 20012002

\begin{tabular}{|c|c|c|c|}
\hline & $\%$ & typering & trend $2000-2002$ \\
\hline WO sociale wetenschappen & 3 & laag & - \\
\hline \multicolumn{4}{|l|}{ Beroepen } \\
\hline Pedagogische beroepen & 12 & hoog & constant \\
\hline Leraar basisonderwijs & 9 & gemiddeld & sterk dalend \\
\hline Docenten exacte, medische en verzorgende vakken ( 2 e graads) & 5 & gemiddeld & sterk dalend \\
\hline Docenten landbouw en techniek (2e graads) & 30 & erg hoog & - \\
\hline Docenten economisch-administratieve vakken (2e graads) & 30 & erg hoog & sterk stijgend \\
\hline Docenten talen en expressie & 15 & hoog & - \\
\hline Docenten letteren (1e graads) & 12 & hoog & sterk stijgend \\
\hline Docenten sociale vakken (2e graads) & 29 & erg hoog & sterk stijgend \\
\hline Culturele beroepen & 2 & laag & - \\
\hline Agrarische beroepen & 11 & gemiddeld & sterk dalend \\
\hline Technische, ambachts- en industrieberoepen & 8 & gemiddeld & - \\
\hline Conciërges & 5 & gemiddeld & - \\
\hline Economisch-administratieve beroepen & 1 & erg laag & - \\
\hline Receptionisten en administratieve employés & 3 & laag & sterk stijgend \\
\hline Boekhouders en secretaresses & 1 & erg laag & - \\
\hline Assistent accountants & 1 & erg laag & constant \\
\hline Juridisch en fiscaal medewerkers & 1 & erg laag & constant \\
\hline Leidinggevenden & 1 & erg laag & sterk stijgend \\
\hline Managers & 0 & erg laag & sterk dalend \\
\hline Informatica beroepen & 1 & erg laag & sterk stijgend \\
\hline Systeemanalisten & 2 & laag & sterk stijgend \\
\hline Sociaal-culturele beroepen & 4 & gemiddeld & sterk stijgend \\
\hline Verzorgende en dienstverlenende beroepen & 8 & gemiddeld & - \\
\hline Openbare orde- en veiligheidsberoepen & 7 & gemiddeld & sterk dalend \\
\hline Aspirant politieagenten, soldaten en beveiligingshulpkrachten & 10 & gemiddeld & sterk dalend \\
\hline Politieagenten, onderofficieren en beveiligingsemployés & 4 & gemiddeld & constant \\
\hline \multicolumn{4}{|l|}{ Specifieke groepen werkenden } \\
\hline Vrouwen & 6 & gemiddeld & sterk dalend \\
\hline Jongeren & 8 & gemiddeld & \\
\hline Ouderen & 7 & gemiddeld & sterk stijgend \\
\hline Allochtonen & 5 & gemiddeld & - \\
\hline Totaal & 6 & gemiddeld & constant \\
\hline
\end{tabular}

Bron: ROA/CBS 


\section{Overheid en onderwijs}

Tabel 13.3

Percentage werkenden dat regelmatig werkt met trillende apparaten, gemiddelde 2001-2002

$\%$ typering

trend 2000-2002

Opleidingen

Basisonderwijs

VMBO theorie

VMBO natuur en techniek

VMBO economie

HAVO/VWO

MBO natuur en techniek

MBO milieu en groene ruimte

$M B O$ openbare orde en veiligheid

MBO economie

MBO administratie

MBO dienstverlening en gezondheidszorg

MBO sociaal-cultureel

$\mathrm{HO}$ natuur en techniek

WO wiskunde en natuurwetenschappen

$\mathrm{HO}$ onderwijs en sociaal-cultureel

HBO lerarenopleiding basisonderwijs

HBO lerarenopleiding natuur en techniek

HBO lerarenopleiding expressie

WO sociale wetenschappen

\section{Beroepen}

Pedagogische beroepen

Leraar basisonderwijs

Docenten exacte, medische en verzorgende vakken (2e graads)

Docenten landbouw en techniek (2e graads)

Docenten talen en expressie

Docenten letteren (1e graads)

Agrarische beroepen

Agrarische arbeiders

Technische, ambachts- en industrieberoepen

Conciërges

Monteurs

Economisch-administratieve beroepen

Receptionisten en administratieve employés

Juridisch en fiscaal medewerkers

Managers

Sociaal-culturele beroepen

Verzorgende en dienstverlenende beroepen

Openbare orde- en veiligheidsberoepen

Aspirant politieagenten, soldaten en beveiligingshulpkrachten

Politieagenten, onderofficieren en beveiligingsemployés

Specifieke groepen werkenden

Vrouwen

Jongeren

Ouderen

Allochtonen

Totaal
7 gemiddeld -

2 laag

24 hoog sterk stijgend

5 gemiddeld sterk stijgend

2 laag

19 hoog

40 erg hoog

9 gemiddeld

4 gemiddeld

0 erg laag

1 laag

0 erg laag

2 laag

1 laag

1 laag

0 erg laag

6 gemiddeld

8 gemiddeld

0 erg laag

sterk stijgend

sterk stijgend

sterk stijgend

sterk stijgend

constant

sterk dalend

sterk dalend

sterk dalend

sterk stijgend

sterk stijgend

constant

sterk dalend

sterk stijgend

constant

\section{2 laag}

0 erg laag

sterk stijgend

1 laag

25 hoog

3 gemiddeld

3 gemiddeld

39 erg hoog

55 erg hoog

12 hoog

1 laag

39 erg hoog

0 erg laag

0 erg laag

0 erg laag

1 laag

0 erg laag

5 gemiddeld

9 gemiddeld

11 gemiddeld

5 gemiddeld

constant

sterk dalend

sterk stijgend

sterk stijgend

sterk stijgend

stijgend

sterk dalend

sterk stijgend

sterk dalend

sterk dalend

sterk stijgend

sterk dalend

sterk dalend

sterk stijgend

1 laag

5 gemiddeld

3 gemiddeld

1 laag

constant

sterk dalend

3 gemiddeld

stijgend 
Tabel 13.4

Percentage werkenden dat regelmatig kracht moet zetten tijdens het werk, gemiddelde 2001-2002

Opleidingen

Basisonderwijs

VMBO theorie

VMBO natuur en techniek

VMBO bouwtechniek

VMBO economie

$\mathrm{HAVO} / \mathrm{VWO}$

MBO natuur en techniek

MBO milieu en groene ruimte

$\mathrm{MBO}$ openbare orde en veiligheid

MBO economie

MBO administratie

MBO handel

MBO secretariaat

$\mathrm{MBO}$ dienstverlening en gezondheidszorg

MBO sociaal-cultureel

$\mathrm{HO}$ natuur en techniek

WO wiskunde en natuurwetenschappen

$\mathrm{HO}$ economie

WO rechten en bestuurskunde

$\mathrm{HO}$ onderwijs en sociaal-culturee

HBO lerarenopleiding basisonderwijs

HBO lerarenopleiding talen

HBO lerarenopleiding natuur en techniek

HBO lerarenopleiding lichamelijke opvoeding

HBO lerarenopleiding expressie

HBO maatschappelijk werk en hulpverlening

WO sociale wetenschappen

\section{Beroepen}

Pedagogische beroepen

Leraar basisonderwijs

Docenten exacte, medische en verzorgende vakken (2e graads)

Docenten talen en expressie

Docenten letteren (1e graads)

Docenten sociale vakken (2e graads)

Culturele beroepen

Agrarische beroepen

Agrarische arbeiders

Technische, ambachts- en industrieberoepen

Conciërges

Monteurs

Transportberoepen

Economisch-administratieve beroepen

Receptionisten en administratieve employés

Boekhouders en secretaresses

Juridisch en fiscaal medewerkers

Juristen

Leidinggevenden

Managers

Informatica beroepen

Systeemanalisten
$\%$ typering

trend 2000-2002

26 gemiddeld dalend

6 gemiddeld

34 hoog

49 erg hoog

15 gemiddeld

8 gemiddeld

23 gemiddeld

54 erg hoog

13 gemiddeld

7 gemiddeld

1 laag

1 laag

1 laag

11 gemiddeld

7 gemiddeld

1 laag

2 laag

2 laag

2 laag

3 laag

3 laag

1 laag

1 laag

34 hoog

7 gemiddeld

1 erg laag

1 laag

-

sterk stijgend

sterk stijgend

sterk stijgend

constant

sterk stijgend

sterk stijgend

sterk stijgend

constant

-

sterk stijgend

sterk stijgend

sterk dalend

sterk dalend

sterk dalend

stijgend

sterk stijgend

sterk dalend

-

4 laag

3 laag

1 laag

3 laag

7 gemiddeld

31 gemiddeld

3 laag

36 hoog

56 erg hoog

20 gemiddeld

27 gemiddeld

46 hoog

25 gemiddeld

1 laag

3 laag

0 erg laag

1 laag

0 erg laag

1 laag

2 laag

2 laag

1 laag sterk dalend

constant

sterk stijgend

sterk dalend

sterk dalend

constant

sterk dalend

sterk dalend

constant

sterk dalend

sterk dalend 
Overheid en onderwijs

Tabel 13.4 (vervolg)

Percentage werkenden dat regelmatig kracht moet zetten tijdens het werk- gemiddelde 2001-2002

\begin{tabular}{|c|c|c|c|}
\hline & $\%$ & typering & trend $2000-2002$ \\
\hline Sociaal-culturele beroepen & 0 & erg laag & sterk stijgend \\
\hline Verzorgende en dienstverlenende beroepen & 32 & hoog & constant \\
\hline Interieurverzorgers & 33 & hoog & sterk dalend \\
\hline Openbare orde- en veiligheidsberoepen & 19 & gemiddeld & sterk stijgend \\
\hline Aspirant politieagenten, soldaten en beveiligingshulpkrachten & 28 & gemiddeld & sterk stijgend \\
\hline Politieagenten, onderofficieren en beveiligingsemployés & 12 & gemiddeld & sterk stijgend \\
\hline \multicolumn{4}{|l|}{ Specifieke groepen werkenden } \\
\hline Vrouwen & 4 & laag & sterk dalend \\
\hline Jongeren & 12 & gemiddeld & sterk stijgend \\
\hline Ouderen & 6 & gemiddeld & dalend \\
\hline Allochtonen & 5 & gemiddeld & sterk dalend \\
\hline Totaal & 7 & gemiddeld & - \\
\hline
\end{tabular}

Bron: ROA/CBS 
Tabel 13.5

Percentage werkenden dat regelmatig onder hoge tijdsdruk werkt, gemiddelde 2001-2002

\begin{tabular}{|c|c|c|c|}
\hline & $\%$ & typering & trend $2000-2002$ \\
\hline \multicolumn{4}{|l|}{ Opleidingen } \\
\hline Basisonderwijs & 17 & erg laag & - \\
\hline VMBO theorie & 23 & laag & constant \\
\hline VMBO natuur en techniek & 17 & erg laag & sterk stijgend \\
\hline VMBO economie & 23 & laag & constant \\
\hline HAVO/VWO & 23 & laag & sterk dalend \\
\hline MBO natuur en techniek & 21 & laag & sterk stijgend \\
\hline MBO openbare orde en veiligheid & 33 & gemiddeld & constant \\
\hline MBO economie & 30 & gemiddeld & constant \\
\hline MBO administratie & 32 & gemiddeld & \\
\hline MBO handel & 20 & laag & sterk dalend \\
\hline MBO secretariaat & 24 & laag & sterk dalend \\
\hline MBO dienstverlening en gezondheidszorg & 28 & gemiddeld & constant \\
\hline MBO sociaal-cultureel & 25 & laag & - \\
\hline MBO verzorging & 33 & gemiddeld & - \\
\hline MBO geld, bank en belastingen & 28 & gemiddeld & - \\
\hline $\mathrm{HO}$ natuur en techniek & 33 & gemiddeld & dalend \\
\hline HBO civiele techniek & 42 & hoog & - \\
\hline HBO openbare orde en veiligheid & 46 & erg hoog & dalend \\
\hline WO wiskunde en natuurwetenschappen & 35 & gemiddeld & - \\
\hline $\mathrm{HO}$ economie & 38 & gemiddeld & dalend \\
\hline HBO recht en bestuur & 39 & hoog & - \\
\hline HBO bedrijfskunde & 41 & hoog & sterk dalend \\
\hline WO econom(etr)ie & 37 & gemiddeld & sterk dalend \\
\hline WO bedrijfskunde & 51 & erg hoog & sterk stijgend \\
\hline WO rechten en bestuurskunde & 36 & gemiddeld & - \\
\hline HO onderwijs en sociaal-cultureel & 36 & gemiddeld & dalend \\
\hline HBO lerarenopleiding basisonderwijs & 32 & gemiddeld & dalend \\
\hline HBO lerarenopleiding talen & 34 & gemiddeld & sterk dalend \\
\hline HBO lerarenopleiding natuur en techniek & 32 & gemiddeld & - \\
\hline HBO lerarenopleiding economie en maatschappij & 47 & erg hoog & constant \\
\hline HBO lerarenopleiding expressie & 39 & hoog & constant \\
\hline HBO maatschappelijk werk en hulpverlening & 39 & hoog & - \\
\hline HBO personeel en arbeid & 39 & hoog & - \\
\hline WO letteren & 43 & hoog & dalend \\
\hline WO sociale wetenschappen & 39 & hoog & - \\
\hline HO medisch & 32 & gemiddeld & sterk dalend \\
\hline \multicolumn{4}{|l|}{ Beroepen } \\
\hline Pedagogische beroepen & 35 & gemiddeld & dalend \\
\hline Leraar basisonderwijs & 32 & gemiddeld & dalend \\
\hline Docenten exacte, medische en verzorgende vakken (2e graads) & 33 & gemiddeld & sterk dalend \\
\hline Docenten exacte, medische en verzorgende vakken (1e graads) & 43 & hoog & constant \\
\hline Docenten landbouw en techniek (2e graads) & 30 & gemiddeld & constant \\
\hline Docenten economisch-administratieve vakken (2e graads) & 52 & erg hoog & sterk stijgend \\
\hline Docenten economisch-administratieve vakken (1e graads) & 44 & erg hoog & constant \\
\hline Docenten talen en expressie & 36 & gemiddeld & - \\
\hline Docenten letteren (1e graads) & 40 & hoog & sterk dalend \\
\hline Docenten sociale vakken (2e graads) & 33 & gemiddeld & stijgend \\
\hline Docenten sociale vakken (1e graads) & 43 & hoog & - \\
\hline Onderwijskundigen en pedagogen & 39 & hoog & - \\
\hline Culturele beroepen & 17 & erg laag & - \\
\hline
\end{tabular}


Overheid en onderwijs

Tabel 13.5 (vervolg)

Percentage werkenden dat regelmatig onder hoge tijdsdruk werkt, gemiddelde 2001-2002

\begin{tabular}{|c|c|c|c|}
\hline & $\%$ & typering & trend $2000-2002$ \\
\hline Technische, ambachts- en industrieberoepen & 21 & laag & constant \\
\hline Medische en paramedische beroepen & 32 & gemiddeld & sterk dalend \\
\hline Economisch-administratieve beroepen & 33 & gemiddeld & - \\
\hline Receptionisten en administratieve employés & 22 & laag & - \\
\hline Boekhouders en secretaresses & 26 & gemiddeld & - \\
\hline Assistent accountants & 38 & gemiddeld & sterk dalend \\
\hline Verzekeringsagenten & 46 & erg hoog & sterk stijgend \\
\hline Commercieel employés & 38 & gemiddeld & sterk stijgend \\
\hline Commercieel medewerkers & 37 & gemiddeld & - \\
\hline Juridisch en fiscaal medewerkers & 24 & laag & - \\
\hline Juridisch, bestuurlijk medewerkers & 44 & erg hoog & - \\
\hline Juristen & 36 & gemiddeld & dalend \\
\hline Leidinggevenden & 41 & hoog & sterk dalend \\
\hline Managers & 58 & erg hoog & constant \\
\hline Informatica beroepen & 25 & laag & constant \\
\hline Programmeurs & 27 & gemiddeld & - \\
\hline Systeemanalisten & 24 & laag & - \\
\hline Sociaal-culturele beroepen & 35 & gemiddeld & sterk dalend \\
\hline Activiteitenbegeleiders en medewerkers arbeidsbemiddeling & 30 & gemiddeld & dalend \\
\hline Medewerkers sociaal-cultureel werk en personeel en arbeid & 39 & hoog & dalend \\
\hline Sociaal-wetenschappelijk medewerkers & 36 & gemiddeld & sterk dalend \\
\hline Sociaal-wetenschappelijk onderzoekers & 33 & gemiddeld & sterk dalend \\
\hline Verzorgende en dienstverlenende beroepen & 19 & laag & dalend \\
\hline Openbare orde- en veiligheidsberoepen & 28 & gemiddeld & - \\
\hline Aspirant politieagenten, soldaten en beveiligingshulpkrachten & 21 & laag & dalend \\
\hline Politieagenten, onderofficieren en beveiligingsemployés & 32 & gemiddeld & constant \\
\hline \multicolumn{4}{|l|}{ Specifieke groepen werkenden } \\
\hline Vrouwen & 30 & gemiddeld & dalend \\
\hline Jongeren & 22 & laag & constant \\
\hline Ouderen & 35 & gemiddeld & constant \\
\hline Allochtonen & 23 & laag & - \\
\hline Totaal & 31 & gemiddeld & dalend \\
\hline
\end{tabular}

Bron: ROA/CBS 
Tabel 13.6

Percentage werkenden dat regelmatig beeldschermwerk verricht, gemiddelde 2001-2002

\begin{tabular}{|c|c|c|c|}
\hline & $\%$ & typering & trend $2000-2002$ \\
\hline \multicolumn{4}{|l|}{ Opleidingen } \\
\hline Basisonderwijs & 34 & gemiddeld & sterk stijgend \\
\hline VMBO theorie & 75 & gemiddeld & constant \\
\hline VMBO natuur en techniek & 31 & gemiddeld & - \\
\hline VMBO economie & 50 & gemiddeld & constant \\
\hline VMBO administratie, handel en mode & 68 & gemiddeld & - \\
\hline VMBO verzorging & 33 & gemiddeld & - \\
\hline VMBO (uiterlijke) verzorging & 33 & gemiddeld & - \\
\hline HAVO/VWO & 74 & gemiddeld & dalend \\
\hline MBO natuur en techniek & 44 & gemiddeld & stijgend \\
\hline MBO bouw & 50 & gemiddeld & sterk stijgend \\
\hline MBO grond-, weg- en waterbouw & 58 & gemiddeld & sterk stijgend \\
\hline MBO elektrotechniek & 69 & gemiddeld & - \\
\hline MBO automatisering & 97 & erg hoog & constant \\
\hline MBO openbare orde en veiligheid & 71 & gemiddeld & - \\
\hline MBO economie & 80 & hoog & constant \\
\hline MBO administratie & 91 & hoog & constant \\
\hline MBO handel & 74 & gemiddeld & stijgend \\
\hline MBO secretariaat & 94 & erg hoog & stijgend \\
\hline MBO bedrijfskunde & 73 & gemiddeld & dalend \\
\hline MBO dienstverlening en gezondheidszorg & 57 & gemiddeld & constant \\
\hline MBO sociaal-cultureel & 66 & gemiddeld & - \\
\hline MBO verzorging & 49 & gemiddeld & constant \\
\hline MBO uiterlijke verzorging & 85 & hoog & sterk stijgend \\
\hline MBO geld, bank en belastingen & 86 & hoog & constant \\
\hline $\mathrm{HO}$ natuur en techniek & 74 & gemiddeld & stijgend \\
\hline HBO milieukunde en levensmiddelentechnologie & 97 & erg hoog & constant \\
\hline HBO bouwkunde & 50 & gemiddeld & - \\
\hline HBO civiele techniek & 81 & hoog & constant \\
\hline HBO informatica & 87 & hoog & constant \\
\hline HBO openbare orde en veiligheid & 68 & gemiddeld & sterk dalend \\
\hline WO landbouw en milieukunde & 88 & hoog & stijgend \\
\hline WO wiskunde en natuurwetenschappen & 62 & gemiddeld & sterk stijgend \\
\hline WO bouwkunde & 81 & hoog & sterk stijgend \\
\hline $\mathrm{HO}$ economie & 84 & hoog & constant \\
\hline HBO accountancy en bedrijfseconomie & 95 & erg hoog & stijgend \\
\hline HBO commerciële economie & 78 & hoog & sterk dalend \\
\hline HBO recht en bestuur & 91 & erg hoog & constant \\
\hline HBO secretariaat & 100 & erg hoog & constant \\
\hline HBO bedrijfskunde & 85 & hoog & stijgend \\
\hline WO econom(etr)ie & 82 & hoog & sterk stijgend \\
\hline WO bedrijfskunde & 76 & gemiddeld & constant \\
\hline WO accountancy en belastingen & 93 & erg hoog & - \\
\hline WO rechten en bestuurskunde & 81 & hoog & stijgend \\
\hline $\mathrm{HO}$ onderwijs en sociaal-cultureel & 35 & gemiddeld & constant \\
\hline HBO lerarenopleiding basisonderwijs & 15 & laag & - \\
\hline HBO lerarenopleiding talen & 32 & gemiddeld & dalend \\
\hline HBO lerarenopleiding natuur en techniek & 27 & gemiddeld & - \\
\hline HBO lerarenopleiding economie en maatschappij & 29 & gemiddeld & - \\
\hline HBO lerarenopleiding expressie & 24 & gemiddeld & sterk dalend \\
\hline HBO maatschappelijk werk en hulpverlening & 79 & hoog & sterk stijgend \\
\hline HBO personeel en arbeid & 79 & hoog & dalend \\
\hline
\end{tabular}


Overheid en onderwijs

Tabel 13.6 (vervolg)

Percentage werkenden dat regelmatig beeldschermwerk verricht, gemiddelde 2001-2002

\begin{tabular}{|c|c|c|c|}
\hline & $\%$ & typering & trend $2000-2002$ \\
\hline HBO bibliotheek en documentatie & 93 & erg hoog & - \\
\hline HBO uitvoerende en beeldende kunsten & 50 & gemiddeld & sterk stijgend \\
\hline WO letteren & 53 & gemiddeld & \\
\hline WO sociale wetenschappen & 68 & gemiddeld & constant \\
\hline HO medisch & 55 & gemiddeld & \\
\hline WO (dier)geneeskunde & 76 & gemiddeld & stijgend \\
\hline \multicolumn{4}{|l|}{ Beroepen } \\
\hline Pedagogische beroepen & 23 & laag & constant \\
\hline Leraar basisonderwijs & 12 & laag & - \\
\hline Docenten exacte, medische en verzorgende vakken (2e graads) & 26 & gemiddeld & constant \\
\hline Docenten exacte, medische en verzorgende vakken (1e graads) & 36 & gemiddeld & sterk stijgend \\
\hline Docenten landbouw en techniek ( $2 \mathrm{e}$ graads) & 27 & gemiddeld & sterk dalend \\
\hline Docenten economisch-administratieve vakken (2e graads) & 64 & gemiddeld & sterk stijgend \\
\hline Docenten economisch-administratieve vakken (1e graads) & 62 & gemiddeld & sterk stijgend \\
\hline Docenten talen en expressie & 17 & laag & sterk dalend \\
\hline Docenten letteren (1e graads) & 24 & gemiddeld & sterk dalend \\
\hline Onderwijskundig medewerkers & 60 & gemiddeld & sterk dalend \\
\hline Onderwijskundigen en pedagogen & 69 & gemiddeld & sterk dalend \\
\hline Culturele beroepen & 79 & hoog & - \\
\hline Bibliotheekassistenten & 80 & hoog & constant \\
\hline Bibliothecarissen & 100 & erg hoog & stijgend \\
\hline Agrarische beroepen & 28 & gemiddeld & constant \\
\hline Milieuhygiënisten en agrarisch vertegenwoordigers & 89 & hoog & dalend \\
\hline Technische, ambachts- en industrieberoepen & 46 & gemiddeld & constant \\
\hline Natuurwetenschappers & 94 & erg hoog & constant \\
\hline Conciërges & 19 & laag & stijgend \\
\hline Weg- en waterbouwkundigen & 82 & hoog & stijgend \\
\hline Weg- en waterbouwkundige vakkrachten & 58 & gemiddeld & - \\
\hline Weg- en waterbouwkundig ontwerpers en projectleiders & 92 & erg hoog & sterk stijgend \\
\hline Transportberoepen & 37 & gemiddeld & sterk stijgend \\
\hline Medische en paramedische beroepen & 51 & gemiddeld & constant \\
\hline Artsen & 80 & hoog & - \\
\hline Economisch-administratieve beroepen & 88 & hoog & constant \\
\hline Productieplanners & 87 & hoog & sterk stijgend \\
\hline Organisatie-adviseurs & 91 & erg hoog & sterk stijgend \\
\hline Receptionisten en administratieve employés & 87 & hoog & constant \\
\hline Boekhouders en secretaresses & 96 & erg hoog & constant \\
\hline Assistent accountants & 92 & erg hoog & constant \\
\hline Accountants & 94 & erg hoog & - \\
\hline Verzekeringsagenten & 99 & erg hoog & constant \\
\hline Commercieel employés & 83 & hoog & sterk dalend \\
\hline Commercieel medewerkers & 86 & hoog & dalend \\
\hline Juridisch en fiscaal medewerkers & 89 & hoog & constant \\
\hline Juridisch, bestuurlijk medewerkers & 88 & hoog & constant \\
\hline Juristen & 89 & hoog & constant \\
\hline Leidinggevenden & 80 & hoog & sterk stijgend \\
\hline Managers & 71 & gemiddeld & sterk stijgend \\
\hline Informatica beroepen & 100 & erg hoog & constant \\
\hline Programmeurs & 100 & erg hoog & constant \\
\hline Systeemanalisten & 100 & erg hoog & constant \\
\hline Informatici & 100 & erg hoog & constant \\
\hline Sociaal-culturele beroepen & 83 & hoog & constant \\
\hline Activiteitenbegeleiders en medewerkers arbeidsbemiddeling & 69 & gemiddeld & stijgend \\
\hline Medewerkers sociaal-cultureel werk en personeel en arbeid & 87 & hoog & constant \\
\hline Sociaal-wetenschappelijk medewerkers & 84 & hoog & constant \\
\hline Sociaal-wetenschappelijk onderzoekers & 91 & erg hoog & dalend \\
\hline Verzorgende en dienstverlenende beroepen & 4 & erg laag & sterk dalend \\
\hline
\end{tabular}


Overheid en onderwijs

Tabel 13.6 (vervolg)

Percentage werkenden dat regelmatig beeldschermwerk verricht, gemiddelde 2001-2002

$\%$ typering trend 2000-2002

Openbare orde- en veiligheidsberoepen

55 gemiddeld dalend

Aspirant politieagenten, soldaten en beveiligingshulpkrachten

$\begin{array}{lll}31 & \text { gemiddeld } & \text { sterk } \\ 68 & \text { gemiddeld } & \text { dalend }\end{array}$

sterk dalend

Politieagenten, onderofficieren en beveiligingsemployés

Politie-inspecteurs en officieren

88 hoog

constant

Specifieke groepen werkenden

Vrouwen

54 gemiddeld constant

Jongeren

50 gemiddeld

Ouderen

gemiddeld sterk stijgend

Allochtonen

59 gemiddeld

Totaal

57 gemiddeld

constant

Bron: ROA/CBS 
Tabel 13.7

Percentage werkenden dat deelneemt aan scholingstrajecten korter dan 6 maanden, gemiddelde 2001-2002

\begin{tabular}{|c|c|c|c|}
\hline & $\%$ & typering & trend $2000-2002$ \\
\hline \multicolumn{4}{|l|}{ Opleidingen } \\
\hline Basisonderwijs & 4 & gemiddeld & - \\
\hline VMBO theorie & 5 & gemiddeld & - \\
\hline VMBO natuur en techniek & 10 & erg hoog & sterk stijgend \\
\hline VMBO economie & 6 & hoog & constant \\
\hline HAVO/VWO & 5 & gemiddeld & constant \\
\hline MBO natuur en techniek & 5 & gemiddeld & sterk dalend \\
\hline MBO openbare orde en veiligheid & 9 & erg hoog & - \\
\hline MBO economie & 7 & hoog & dalend \\
\hline MBO administratie & 3 & laag & - \\
\hline MBO secretariaat & 8 & erg hoog & - \\
\hline MBO dienstverlening en gezondheidszorg & 4 & gemiddeld & sterk dalend \\
\hline MBO sociaal-cultureel & 2 & laag & sterk dalend \\
\hline HO natuur en techniek & 5 & gemiddeld & sterk dalend \\
\hline WO wiskunde en natuurwetenschappen & 3 & laag & sterk dalend \\
\hline $\mathrm{HO}$ economie & 5 & gemiddeld & sterk dalend \\
\hline WO rechten en bestuurskunde & 5 & gemiddeld & sterk dalend \\
\hline $\mathrm{HO}$ onderwijs en sociaal-cultureel & 6 & hoog & sterk dalend \\
\hline HBO lerarenopleiding basisonderwijs & 8 & erg hoog & - \\
\hline HBO lerarenopleiding talen & 4 & gemiddeld & sterk dalend \\
\hline HBO lerarenopleiding natuur en techniek & 5 & gemiddeld & sterk dalend \\
\hline HBO lerarenopleiding economie en maatschappij & 9 & erg hoog & - \\
\hline HBO lerarenopleiding expressie & 3 & laag & sterk dalend \\
\hline HBO maatschappelijk werk en hulpverlening & 5 & gemiddeld & \\
\hline WO letteren & 2 & laag & sterk dalend \\
\hline WO sociale wetenschappen & 7 & hoog & dalend \\
\hline \multicolumn{4}{|l|}{ Beroepen } \\
\hline Pedagogische beroepen & 6 & hoog & sterk dalend \\
\hline Leraar basisonderwijs & 8 & erg hoog & - \\
\hline Docenten exacte, medische en verzorgende vakken (2e graads) & 5 & gemiddeld & sterk dalend \\
\hline Docenten talen en expressie & 3 & laag & sterk dalend \\
\hline Docenten letteren (1e graads) & 4 & gemiddeld & - \\
\hline Culturele beroepen & 4 & gemiddeld & sterk dalend \\
\hline Technische, ambachts- en industrieberoepen & 5 & gemiddeld & sterk dalend \\
\hline Economisch-administratieve beroepen & 5 & gemiddeld & sterk dalend \\
\hline Receptionisten en administratieve employés & 4 & gemiddeld & sterk dalend \\
\hline Boekhouders en secretaresses & 4 & gemiddeld & - \\
\hline Assistent accountants & 4 & gemiddeld & sterk dalend \\
\hline Juridisch en fiscaal medewerkers & 8 & erg hoog & sterk stijgend \\
\hline Juristen & 4 & gemiddeld & sterk dalend \\
\hline Leidinggevenden & 3 & laag & - \\
\hline Managers & 8 & hoog & - \\
\hline Informatica beroepen & 8 & hoog & constant \\
\hline Sociaal-culturele beroepen & 6 & hoog & sterk dalend \\
\hline Verzorgende en dienstverlenende beroepen & 4 & gemiddeld & - \\
\hline Openbare orde- en veiligheidsberoepen & 11 & erg hoog & sterk stiigend \\
\hline Aspirant politieagenten, soldaten en beveiligingshulpkrachten & 12 & erg hoog & sterk stijgend \\
\hline Politieagenten, onderofficieren en beveiligingsemployés & 10 & erg hoog & sterk stijgend \\
\hline
\end{tabular}


Overheid en onderwijs

Tabel 13.7 (vervolg)

Percentage werkenden dat deelneemt aan scholingstrajecten korter dan 6 maanden, gemiddelde 2001-2002

$\% \quad$ typering trend $2000-2002$

Specifieke groepen werkenden

Vrouwen

Jongeren

Ouderen

7 hoog sterk dalend

Allochtonen

3 laag

7 hoog

sterk dalend

Totaal

6 hoog

sterk dalend

Bron: ROA/CBS 


\section{Overheid en onderwijs}

Tabel 13.8

Percentage werkenden dat deelneemt aan scholingstrajecten van 6 maanden of langer, gemiddelde 2001 . 2002

$\% \quad$ typering

trend 2000-2002

Opleidingen

Basisonderwijs

VMBO theorie

VMBO natuur en techniek

VMBO economie

HAVO/VWO

MBO natuur en techniek

$\mathrm{MBO}$ openbare orde en veiligheid

$\mathrm{MBO}$ economie

MBO administratie

MBO secretariaat

MBO dienstverlening en gezondheidszorg

MBO sociaal-cultureel

$\mathrm{HO}$ natuur en techniek

WO wiskunde en natuurwetenschappen

$\mathrm{HO}$ economie

$\mathrm{HBO}$ bedrijfskunde

WO rechten en bestuurskunde

$\mathrm{HO}$ onderwijs en sociaal-cultureel

HBO lerarenopleiding basisonderwijs

HBO lerarenopleiding talen

HBO lerarenopleiding natuur en techniek

HBO lerarenopleiding economie en maatschappij

HBO lerarenopleiding expressie

HBO maatschappelijk werk en hulpverlening

WO letteren

WO sociale wetenschappen

$\mathrm{HO}$ medisch

Beroepen

Pedagogische beroepen

Leraar basisonderwijs

Docenten exacte, medische en verzorgende vakken (2e graads)

Docenten talen en expressie

Docenten letteren (1e graads)

Culturele beroepen

Technische, ambachts- en industrieberoepen

Medische en paramedische beroepen

Economisch-administratieve beroepen

Receptionisten en administratieve employés

Boekhouders en secretaresses

Assistent accountants

Juridisch en fiscaal medewerkers

Juristen

Leidinggevenden

Managers

Informatica beroepen

Sociaal-culturele beroepen

Medewerkers sociaal-cultureel werk en personeel en arbeid

Verzorgende en dienstverlenende beroepen

Openbare orde- en veiligheidsberoepen

laag
hoog
gemiddeld
gemiddeld
erg hoog
gemiddeld
laag
gemiddeld
hoog
laag
hoog
hoog
gemiddeld
gemiddeld
hoog
hoog
gemiddeld
gemiddeld
hoog
gemiddeld
laag
gemiddeld
hoog
hoog
laag
gemiddeld
erg hoog

constant

sterk dalend

constant

sterk stijgend

constant

sterk stijgend

stijgend

constant

sterk stijgend

sterk stijgend

stijgend

sterk stijgend

constant

sterk dalend

sterk dalend

sterk stijgend

$\begin{array}{ll}\text { hoog } & \text { stijgend } \\ \text { hoog } & \text { sterk stijgend } \\ \text { hoog } & - \\ \text { hoog } & \text { sterk stijgend } \\ \text { hoog } & - \\ \text { gemiddeld } & - \\ \text { gemiddeld } & \text { sterk stijgend } \\ \text { erg hoog } & \text { sterk stijgend } \\ \text { gemiddeld } & - \\ \text { gemiddeld } & - \\ \text { gemiddeld } & - \\ \text { gemiddeld } & \text { sterk stijgend } \\ \text { hoog } & \text { sterk stijgend } \\ \text { hoog } & - \\ \text { hoog } & - \\ \text { laag } & \text { sterk dalend } \\ \text { gemiddeld } & \text { sterk dalend } \\ \text { gemiddeld } & \text { dalend } \\ \text { gemiddeld } & \text { sterk dalend } \\ \text { gemiddeld } & - \\ \text { hoog } & \text { constant }\end{array}$


Tabel 13.8 (vervolg)

Percentage werkenden dat deelneemt aan scholingstrajecten van 6 maanden of langer, gemiddelde 20012002

$\%$ typering trend 2000-2002

Aspirant politieagenten, soldaten en beveiligingshulpkrachten Politieagenten, onderofficieren en beveiligingsemployés

$\begin{array}{lll}26 & \text { erg hoog } & - \\ 13 & \text { gemiddeld } & \text { constant }\end{array}$

Specifkieke groepen werkenden

Vrouwen

Jongeren

Ouderen

17 hoog

hoog sterk stijgend

Allochtonen

32 erg hoog

stijgend

Totaal

19 hoog

sterk stijgend

14 gemiddeld stijgend

Bron: ROA/CBS 

14. Totaal alle sectoren 

Tabel 14.1

Kernindicatoren

\section{Arbeidsomstandigheden}

Belastende arbeidsomstandigheden

$\%$ werknemers dat regelmatig geconfronteerd wordt met:

$\begin{array}{rrl}2000 & 2001 / 2002 & \text { typering } \\ \% & \% & \\ 10 & 10 & \text { gemiddeld } \\ 8 & 8 & \text { gemiddeld } \\ 23 & 22 & \text { gemiddeld } \\ 31 & 29 & \text { gemiddeld } \\ 44 & 46 & \text { gemiddeld }\end{array}$

Lawaai

Trilling

Kracht zetten

Tijdsdruk

Beeldschermwerk

\section{Technologische en organisatorische ontwikkelingen}

Organisatorische ontwikkelingen

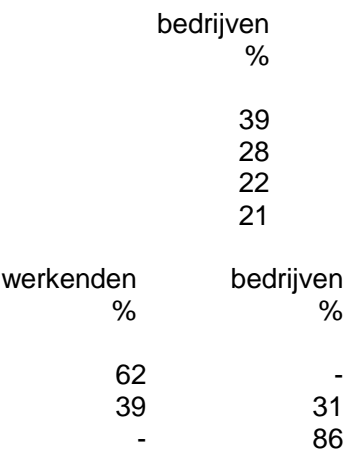

Vernieuwingen in het productieproces, 1999-2001

Automatisering, 2002

jaarlijks \%

Kleine productverandering, 2000-2002

Ingrijpende productverandering, 2000-2002

Veranderingen in positie, 2000-2002

Interne reorganisaties, 2000-2002

Technologische vernieuwingen

Verschuivingen in de werkgelegenheid

Verwachte werkgelegenheidsontwikkeling, 2003-2008

\section{Scholingsdeelname}

\begin{tabular}{lrll}
2000 & $2001 /$ typering \\
& $\%$ & $\begin{array}{r}2002 \\
\%\end{array}$ & \\
& 5 & 4 gemiddeld \\
$\begin{array}{l}\text { Deelname aan opleidingstrajecten korter dan 6 maanden (momentopname) } \\
\text { Deelname aan opleidingstrajecten van 6 maanden of langer (momentopname) }\end{array}$ & 13 & 14 gemiddeld \\
\hline
\end{tabular}

Bron: ROA/CBS/OSA 


\section{Totaal alle sectoren}

Tabel 14.2

Percentage werkenden dat regelmatig wordt geconfronteerd met lawaai tijdens het werk, gemiddelde 20012002

$\%$ typering trend 2000-2002

Opleidingen

Basisonderwijs

VMBO theorie

VMBO natuur en techniek

VMBO landbouw en natuurlijke omgeving

VMBO bouwtechniek

VMBO metaal: mechanische techniek

VMBO voertuigentechniek

VMBO elektrotechniek

VMBO transport en logistiek

VMBO beveiliging

VMBO economie

VMBO administratie, handel en mode

VMBO consumptief en levensmiddelentechniek

VMBO verzorging

HAVO/VWO

MBO natuur en techniek

MBO landbouw en veeteelt

MBO milieu en groene ruimte

MBO laboratorium

MBO bouw

MBO grond-, weg- en waterbouw

MBO installatietechniek

MBO werktuigbouw en mechanische techniek

MBO motorvoertuigentechniek

MBO elektrotechniek

MBO grafische techniek

MBO procestechniek

MBO levensmiddelentechniek/vleesverwerking

$M B O$ vervoer en logistiek

MBO automatisering

MBO openbare orde en veiligheid

MBO economie

MBO administratie

MBO handel

MBO secretariaat

MBO toerisme en recreatie

MBO bedrijfskunde

MBO dienstverlening en gezondheidszorg

MBO dokters-, tandarts- en dierenartsassistent

MBO apothekersassistent

$\mathrm{MBO}$ verpleging

MBO sociaal-cultureel

$\mathrm{MBO}$ verzorging

MBO uiterlijke verzorging

MBO horeca

MBO beweging en therapie

MBO geld, bank en belastingen

$\mathrm{MBO}$ verzekeringswezen

$\mathrm{HO}$ natuur en techniek

HBO milieukunde en levensmiddelentechnologie

HBO laboratorium
18 hoog

9 gemiddeld

24 hoog

18 hoog

22 hoog

34 erg hoog

17 hoog

20 hoog

19 hoog

8 gemiddeld

10 gemiddeld

9 gemiddeld

18 hoog

9 gemiddeld

6 gemiddeld

19 hoog

12 hoog

11 gemiddeld

3 laag

18 hoog

16 hoog

23 hoog

28 hoog

21 hoog

15 hoog

23 hoog

38 erg hoog

18 hoog

12 hoog

7 gemiddeld

14 hoog

5 gemiddeld

3 laag

5 gemiddeld

3 laag

4 gemiddeld

7 gemiddeld

6 gemiddeld

4 gemiddeld

0 erg laag

5 gemiddeld

7 gemiddeld

5 gemiddeld

8 gemiddeld

9 gemiddeld

10 gemiddeld

2 laag

3 laag

5 gemiddeld

3 laag

5 gemiddeld stijgend

sterk stijgend

sterk stijgend

stijgend

sterk stijgend

dalend

sterk stijgend

sterk stijgend

sterk stijgend

stijgend

sterk stijgend

sterk stijgend

sterk dalend

constant

sterk dalend

sterk dalend

constant

sterk stijgend

sterk stijgend

constant

constant

constant

sterk stijgend

sterk dalend

sterk stijgend

sterk stijgend

sterk stijgend

constant

sterk stijgend

sterk stijgend

constant

sterk dalend

sterk dalend

constant

sterk dalend

sterk dalend

sterk stijgend

sterk dalend

sterk dalend

sterk dalend 
Tabel 14.2 (vervolg)

Percentage werkenden dat regelmatig wordt geconfronteerd met lawaai tijdens het werk, gemiddelde 20012002

HBO bouwkunde

HBO civiele techniek

HBO werktuigbouwkunde

HBO elektrotechniek

HBO informatica

HBO vervoer en logistiek

WO wiskunde en natuurwetenschappen

$\mathrm{HO}$ economie

HBO accountancy en bedrijfseconomie

HBO commerciële economie

$\mathrm{HBO}$ recht en bestuur

$\mathrm{HBO}$ secretariaat

HBO bedrijfskunde

WO econom(etr)ie

WO bedrijfskunde

WO rechten en bestuurskunde

$\mathrm{HO}$ onderwijs en sociaal-cultureel

HBO lerarenopleiding basisonderwijs

HBO lerarenopleiding talen

HBO lerarenopleiding natuur en techniek

HBO lerarenopleiding economie en maatschappij

HBO lerarenopleiding lichamelijke opvoeding

HBO lerarenopleiding expressie

HBO communicatie en journalistiek

HBO maatschappelijk werk en hulpverlening

HBO personeel en arbeid

HBO uitvoerende en beeldende kunsten

WO letteren

WO sociale wetenschappen

$\mathrm{HO}$ medisch

HBO verpleegkunde

$\mathrm{HBO}$ (fysio)therapie

WO (dier)geneeskunde

\section{Beroepen}

Pedagogische beroepen

Leraar basisonderwijs

Docenten exacte, medische en verzorgende vakken (2e graads)

Docenten landbouw en techniek (2e graads)

Docenten economisch-administratieve vakken (2e graads)

Docenten talen en expressie

Docenten letteren (1e graads)

Docenten sociale vakken (2e graads)

Onderwijskundigen en pedagogen

Culturele beroepen

Bibliotheekassistenten

Kunstenaars

Journalisten

Agrarische beroepen

Agrarische arbeiders

Technische, ambachts- en industrieberoepen

Productiemedewerkers

Laboranten

Natuurwetenschappers

Conciërges

Hoofden technische dienst

Bouwvakkers
4 gemiddeld -

8 gemiddeld sterk stijgend

5 gemiddeld

2 laag

2 laag

34 erg hoog

4 gemiddeld sterk dalend

2 laag

1 erg laag

1 erg laag

0 erg laag

2 laag

6 gemiddeld sterk stijgend

3 laag

1 erg laag

0 erg laag

6 gemiddeld

9 gemiddeld

13 hoog

10 gemiddeld

4 gemiddeld

29 erg hoog

14 hoog

6 gemiddeld

3 laag

0 erg laag

8 gemiddeld

1 erg laag

1 erg laag

3 laag

1 erg laag

6 gemiddeld

3 laag

12 hoog

9 gemiddeld

5 gemiddeld

29 erg hoog

28 hoog

14 hoog

12 hoog

29 erg hoog

3 laag

2 laag

1 erg laag

6 gemiddeld

1 erg laag

11 gemiddeld

11 gemiddeld

26 hoog

30 erg hoog

8 gemiddeld

7 gemiddeld

6 gemiddeld

22 hoog

25 hoog sterk stijgend

ste

constant

constant

sterk dalend

sterk stijgend

sterk dalend

sterk stijgend

sterk stijgend

sterk dalend

sterk dalend

constant

sterk dalend

sterk dalend

sterk dalend

constant

sterk dalend

sterk dalend

constant

sterk stijgend

sterk stijgend

sterk dalend

sterk dalend

sterk stijgend

sterk dalend

sterk dalend

constant

sterk stijgend 
Tabel 14.2 (vervolg)

Percentage werkenden dat regelmatig wordt geconfronteerd met lawaai tijdens het werk, gemiddelde 20012002

Aannemers en installateurs

Architecten en bouwkundig projectleiders

Weg- en waterbouwkundige arbeiders

Weg- en waterbouwkundige vakkrachten

Metaalarbeiders

Bankwerkers en lassers

Assembleurs

Monteurs

Werktuigbouwkundig ontwerpers en hoofden technische dienst

Monteurs en controleurs elektrotechnische producten

Elektromonteurs

Grafisch productiepersoneel

Grafische vakkrachten

Mechanisch operators

Procesoperators

Confectie-arbeiders

Transportberoepen

Laders en lossers

Chauffeurs

Vliegers, scheepskapiteins en leidinggevenden transport

Stewards

Medische en paramedische beroepen

Verpleeghulpen en leerling-verpleegkundigen

Verplegenden en doktersassistenten

Therapeuten en verpleegkundigen

Artsen

Apothekersassistenten en medisch laboranten

Medisch analisten

Economisch-administratieve beroepen

Kantoorhulpen, inpakkers en colporteurs

Bedrijfshoofden

Productieplanners

Organisatie-adviseurs

Organisatiedeskundigen

Receptionisten en administratieve employés

Boekhouders en secretaresses

Assistent accountants

Verzekeringsagenten

Commercieel employés

Commercieel medewerkers

Juridisch en fiscaal medewerkers

Juridisch, bestuurlijk medewerkers

Administratieve transportemployés

Leidinggevenden

Managers

Medisch secretaresses

Informatica beroepen

Programmeurs

Systeemanalisten

Sociaal-culturele beroepen

Activiteitenbegeleiders en medewerkers arbeidsbemiddeling

Medewerkers sociaal-cultureel werk en personeel en arbeid

Verzorgende en dienstverlenende beroepen

Vakkenvullers

Interieurverzorgers

Verkopers

Winkeliers

$\begin{array}{rll}19 & \text { hoog } & \text { stijgend } \\ 4 & \text { gemiddeld } & \text { dalend } \\ 25 & \text { hoog } & - \\ 27 & \text { hoog } & \text { constant } \\ 51 & \text { erg hoog } & \text { constant } \\ 49 & \text { erg hoog } & \text { constant } \\ 23 & \text { hoog } & - \\ 31 & \text { erg hoog } & \text { stijgend }\end{array}$

17 hoog

16 hoog

16 hoog

26 hoog

44 erg hoog

41 erg hoog

31 erg hoog

18 hoog

16 hoog

17 hoog

13 hoog

30 erg hoog

39 erg hoog

3 laag

3 laag

4 gemiddeld sterk stijgend

2 laag

4 gemiddeld sterk stijgend

2 laag

5 gemiddeld

3 laag

28 hoog

sterk stijgend

sterk stijgend

constant

stijgend

sterk stijgend

sterk stijgend

stijgend

sterk stijgend

constant

sterk stijgend

dalend

stijgend

0 erg laag sterk dalend

7 gemiddeld

2 laag

1 erg laag

3 gemiddeld

2 laag

1 erg laag

3 laag

2 laag

1 erg laag

1 erg laag

1 erg laag

5 gemiddeld

4 gemiddeld

3 gemiddeld

1 erg laag

1 erg laag

3 laag

1 erg laag

3 gemiddeld

6 gemiddeld

2 laag

6 gemiddeld

constant

sterk dalend

sterk stijgend

constant

sterk stijgend

sterk dalend

constant

sterk stijgend

sterk stijgend

sterk dalend

sterk stijgend

sterk stijgend

constant

sterk stijgend

sterk dalend

stijgend

10 gemiddeld sterk stijgend

10 gemiddeld sterk stijgend

2 laag

3 laag 
Totaal alle sectoren

Tabel 14.2 (vervolg)

Percentage werkenden dat regelmatig wordt geconfronteerd met lawaai tijdens het werk, gemiddelde 20012002

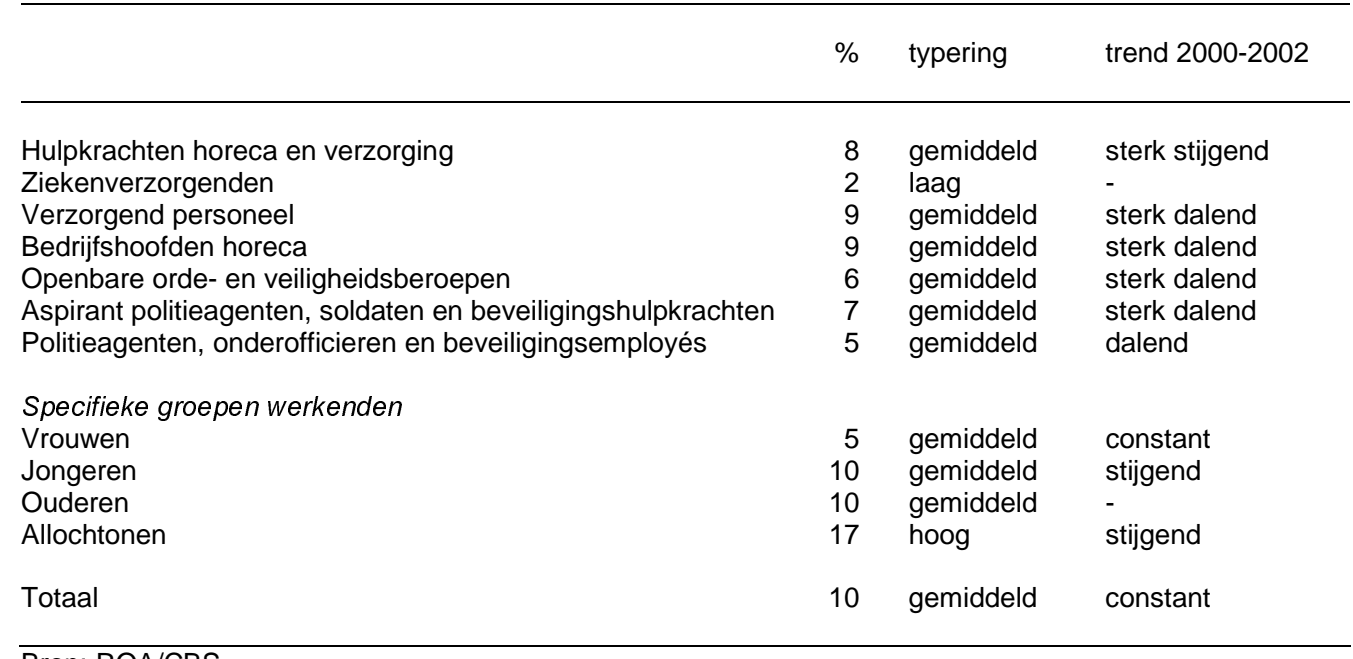

Bron: ROA/CBS 
Tabel 14.3

Percentage werkenden dat regelmatig werkt met trillende apparaten, gemiddelde 2001-2002

\begin{tabular}{|c|c|c|c|}
\hline & $\%$ & typering & trend $2000-2002$ \\
\hline \multicolumn{4}{|l|}{ Opleidingen } \\
\hline Basisonderwijs & 12 & hoog & constant \\
\hline VMBO theorie & 7 & gemiddeld & sterk stijgend \\
\hline VMBO natuur en techniek & 27 & hoog & stijgend \\
\hline VMBO landbouw en natuurlijke omgeving & 23 & hoog & constant \\
\hline VMBO bouwtechniek & 33 & erg hoog & - \\
\hline VMBO installatietechniek & 34 & erg hoog & - \\
\hline VMBO metaal: mechanische techniek & 30 & hoog & stijgend \\
\hline VMBO voertuigentechniek & 25 & hoog & - \\
\hline VMBO elektrotechniek & 21 & hoog & - \\
\hline VMBO transport en logistiek & 16 & hoog & sterk stijgend \\
\hline VMBO beveiliging & 5 & gemiddeld & sterk stijgend \\
\hline VMBO economie & 7 & gemiddeld & stijgend \\
\hline VMBO administratie, handel en mode & 5 & gemiddeld & sterk dalend \\
\hline VMBO consumptief en levensmiddelentechniek & 14 & hoog & sterk stijgend \\
\hline VMBO verzorging & 3 & gemiddeld & sterk dalend \\
\hline HAVO/VWO & 3 & gemiddeld & - \\
\hline MBO natuur en techniek & 23 & hoog & constant \\
\hline MBO landbouw en veeteelt & 17 & hoog & - \\
\hline MBO milieu en groene ruimte & 39 & erg hoog & sterk dalend \\
\hline MBO laboratorium & 4 & gemiddeld & - \\
\hline MBO bouw & 33 & erg hoog & constant \\
\hline MBO grond-, weg- en waterbouw & 23 & hoog & sterk stijgend \\
\hline MBO installatietechniek & 37 & erg hoog & dalend \\
\hline MBO werktuigbouw en mechanische techniek & 26 & hoog & - \\
\hline MBO motorvoertuigentechniek & 41 & erg hoog & sterk stijgend \\
\hline MBO elektrotechniek & 16 & hoog & constant \\
\hline MBO grafische techniek & 12 & hoog & constant \\
\hline MBO procestechniek & 12 & hoog & - \\
\hline MBO levensmiddelentechniek/vleesverwerking & 13 & hoog & sterk stijgend \\
\hline MBO vervoer en logistiek & 11 & gemiddeld & constant \\
\hline MBO automatisering & 3 & gemiddeld & sterk dalend \\
\hline MBO openbare orde en veiligheid & 12 & hoog & sterk stijgend \\
\hline MBO economie & 4 & gemiddeld & sterk stijgend \\
\hline MBO administratie & 2 & laag & sterk dalend \\
\hline MBO handel & 5 & gemiddeld & sterk stijgend \\
\hline MBO secretariaat & 1 & laag & - \\
\hline MBO toerisme en recreatie & 1 & laag & sterk stijgend \\
\hline MBO bedrijfskunde & 5 & gemiddeld & sterk dalend \\
\hline MBO dienstverlening en gezondheidszorg & 3 & gemiddeld & - \\
\hline MBO dokters-, tandarts- en dierenartsassistent & 5 & gemiddeld & sterk dalend \\
\hline MBO apothekersassistent & 0 & erg laag & sterk dalend \\
\hline MBO verpleging & 1 & laag & - \\
\hline MBO sociaal-cultureel & 1 & laag & sterk dalend \\
\hline MBO verzorging & 1 & laag & sterk dalend \\
\hline MBO uiterlijke verzorging & 11 & gemiddeld & sterk stijgend \\
\hline MBO horeca & 5 & gemiddeld & - \\
\hline MBO beweging en therapie & 3 & gemiddeld & sterk stijgend \\
\hline MBO geld, bank en belastingen & 1 & laag & constant \\
\hline MBO verzekeringswezen & 0 & erg laag & sterk dalend \\
\hline HO natuur en techniek & 3 & gemiddeld & dalend \\
\hline HBO milieukunde en levensmiddelentechnologie & 3 & gemiddeld & constant \\
\hline HBO laboratorium & 8 & gemiddeld & - \\
\hline HBO bouwkunde & 3 & gemiddeld & - \\
\hline HBO civiele techniek & 4 & gemiddeld & - \\
\hline HBO werktuigbouwkunde & 3 & gemiddeld & - \\
\hline HBO elektrotechniek & 2 & laag & sterk dalend \\
\hline
\end{tabular}


Tabel 14.3 (vervolg)

Percentage werkenden dat regelmatig met trillende apparaten werkt, gemiddelde 2001-2002

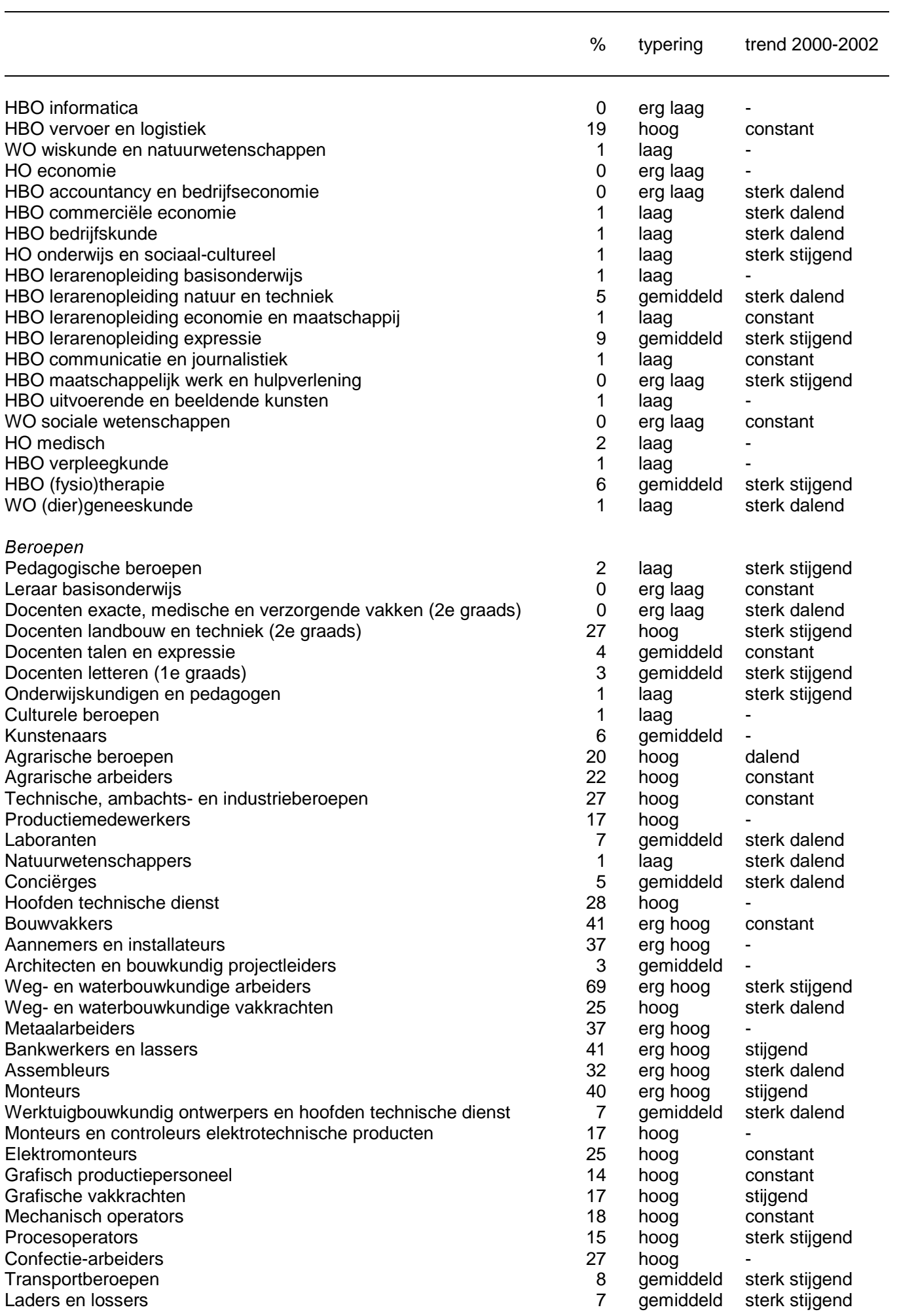


Tabel 14.3 (vervolg)

Percentage werkenden dat regelmatig met trillende apparaten werkt, gemiddelde 2001-2002

\begin{tabular}{|c|c|c|c|}
\hline & $\%$ & typering & trend $2000-2002$ \\
\hline Chauffeurs & 9 & gemiddeld & sterk stijgend \\
\hline Vliegers, scheepskapiteins en leidinggevenden transport & 12 & hoog & - \\
\hline Medische en paramedische beroepen & 4 & gemiddeld & sterk dalend \\
\hline Verpleeghulpen en leerling-verpleegkundigen & 1 & laag & sterk dalend \\
\hline Verplegenden en doktersassistenten & 4 & gemiddeld & sterk dalend \\
\hline Therapeuten en verpleegkundigen & 2 & laag & sterk dalend \\
\hline Artsen & 4 & gemiddeld & sterk stijgend \\
\hline Apothekersassistenten en medisch laboranten & 11 & gemiddeld & sterk dalend \\
\hline Medisch analisten & 7 & gemiddeld & sterk dalend \\
\hline Economisch-administratieve beroepen & 1 & laag & sterk dalend \\
\hline Kantoorhulpen, inpakkers en colporteurs & 7 & gemiddeld & - \\
\hline Bedrijfshoofden & 1 & laag & - \\
\hline Productieplanners & 2 & laag & sterk dalend \\
\hline Organisatie-adviseurs & 0 & erg laag & sterk dalend \\
\hline Receptionisten en administratieve employés & 1 & laag & sterk dalend \\
\hline Boekhouders en secretaresses & 1 & laag & sterk dalend \\
\hline Commercieel employés & 0 & erg laag & - \\
\hline Commercieel medewerkers & 1 & laag & - \\
\hline Juridisch en fiscaal medewerkers & 0 & erg laag & sterk stijgend \\
\hline Administratieve transportemployés & 2 & laag & sterk stijgend \\
\hline Leidinggevenden & 1 & laag & sterk dalend \\
\hline Managers & 1 & laag & - \\
\hline Informatica beroepen & 0 & erg laag & - \\
\hline Programmeurs & 0 & erg laag & - \\
\hline Systeemanalisten & 0 & erg laag & - \\
\hline Sociaal-culturele beroepen & 0 & erg laag & - \\
\hline Activiteitenbegeleiders en medewerkers arbeidsbemiddeling & 0 & erg laag & sterk dalend \\
\hline Medewerkers sociaal-cultureel werk en personeel en arbeid & 0 & erg laag & sterk dalend \\
\hline Verzorgende en dienstverlenende beroepen & 3 & gemiddeld & constant \\
\hline Vakkenvullers & 2 & laag & sterk dalend \\
\hline Interieurverzorgers & 3 & gemiddeld & - \\
\hline Verkopers & 3 & gemiddeld & sterk stijgend \\
\hline Winkeliers & 2 & laag & - \\
\hline Hulpkrachten horeca en verzorging & 2 & laag & sterk stijgend \\
\hline Ziekenverzorgenden & 0 & erg laag & stijgend \\
\hline Verzorgend personeel & 4 & gemiddeld & sterk stijgend \\
\hline Bedrijfshoofden horeca & 3 & gemiddeld & - \\
\hline Openbare orde- en veiligheidsberoepen & 7 & gemiddeld & sterk stijgend \\
\hline Aspirant politieagenten, soldaten en beveiligingshulpkrachten & 7 & gemiddeld & stijgend \\
\hline Politieagenten, onderofficieren en beveiligingsemployés & 5 & gemiddeld & - \\
\hline \multicolumn{4}{|l|}{ Specifieke groepen werkenden } \\
\hline Vrouwen & 2 & laag & dalend \\
\hline Jongeren & 9 & gemiddeld & constant \\
\hline Ouderen & 7 & gemiddeld & dalend \\
\hline Allochtonen & 8 & gemiddeld & constant \\
\hline Totaal & 8 & gemiddeld & constant \\
\hline
\end{tabular}

Bron: ROA/CBS 
Tabel 14.4

Percentage werkenden dat regelmatig kracht moet zetten tijdens het werk, gemiddelde 2001-2002

\begin{tabular}{|c|c|c|c|}
\hline & $\%$ & typering & trend 2000-2002 \\
\hline \multicolumn{4}{|l|}{ Opleidingen } \\
\hline Basisonderwijs & 38 & hoog & constant \\
\hline VMBO theorie & 23 & gemiddeld & constant \\
\hline VMBO natuur en techniek & 49 & erg hoog & constant \\
\hline VMBO landbouw en natuurlijke omgeving & 40 & hoog & dalend \\
\hline VMBO bouwtechniek & 59 & erg hoog & sterk stijgend \\
\hline VMBO installatietechniek & 63 & erg hoog & - \\
\hline VMBO metaal: mechanische techniek & 50 & erg hoog & - \\
\hline VMBO voertuigentechniek & 48 & erg hoog & constant \\
\hline VMBO elektrotechniek & 37 & hoog & dalend \\
\hline VMBO brood en banket & 56 & erg hoog & constant \\
\hline VMBO transport en logistiek & 39 & hoog & constant \\
\hline VMBO beveiliging & 15 & gemiddeld & sterk dalend \\
\hline VMBO economie & 26 & gemiddeld & - \\
\hline VMBO administratie, handel en mode & 23 & gemiddeld & constant \\
\hline VMBO consumptief en levensmiddelentechniek & 41 & hoog & sterk stijgend \\
\hline VMBO verzorging & 32 & hoog & constant \\
\hline HAVO/VWO & 15 & gemiddeld & constant \\
\hline MBO natuur en techniek & 34 & hoog & stijgend \\
\hline MBO landbouw en veeteelt & 42 & hoog & constant \\
\hline MBO milieu en groene ruimte & 58 & erg hoog & - \\
\hline MBO laboratorium & 13 & gemiddeld & sterk stijgend \\
\hline MBO bouw & 41 & hoog & constant \\
\hline MBO grond-, weg- en waterbouw & 28 & gemiddeld & sterk stijgend \\
\hline MBO installatietechniek & 58 & erg hoog & constant \\
\hline MBO werktuigbouw en mechanische techniek & 34 & hoog & sterk stijgend \\
\hline MBO motorvoertuigentechniek & 48 & erg hoog & sterk stijgend \\
\hline MBO elektrotechniek & 24 & gemiddeld & constant \\
\hline MBO grafische techniek & 25 & gemiddeld & sterk stijgend \\
\hline MBO procestechniek & 28 & gemiddeld & sterk stijgend \\
\hline MBO brood en banket & 47 & erg hoog & sterk dalend \\
\hline MBO levensmiddelentechniek/vleesverwerking & 42 & hoog & stijgend \\
\hline MBO vervoer en logistiek & 20 & gemiddeld & sterk dalend \\
\hline MBO automatisering & 5 & gemiddeld & - \\
\hline MBO openbare orde en veiligheid & 19 & gemiddeld & sterk stijgend \\
\hline MBO economie & 13 & gemiddeld & - \\
\hline MBO administratie & 7 & gemiddeld & dalend \\
\hline MBO handel & 22 & gemiddeld & - \\
\hline MBO secretariaat & 6 & gemiddeld & - \\
\hline MBO toerisme en recreatie & 3 & laag & sterk dalend \\
\hline MBO bedrijfskunde & 16 & gemiddeld & constant \\
\hline MBO dienstverlening en gezondheidszorg & 37 & hoog & dalend \\
\hline MBO dokters-, tandarts- en dierenartsassistent & 10 & gemiddeld & sterk dalend \\
\hline MBO apothekersassistent & 2 & laag & - \\
\hline MBO verpleging & 48 & erg hoog & dalend \\
\hline MBO sociaal-cultureel & 26 & gemiddeld & constant \\
\hline MBO verzorging & 51 & erg hoog & dalend \\
\hline MBO uiterlijke verzorging & 14 & gemiddeld & constant \\
\hline MBO horeca & 30 & gemiddeld & constant \\
\hline MBO beweging en therapie & 27 & gemiddeld & - \\
\hline MBO geld, bank en belastingen & 2 & laag & - \\
\hline MBO verzekeringswezen & 1 & laag & - \\
\hline
\end{tabular}


Tabel 14.4 (vervolg)

Percentage werkenden dat regelmatig kracht moet zetten tijdens het werk, gemiddelde 2001-2002

\begin{tabular}{|c|c|c|c|}
\hline & $\%$ & typering & trend 2000-2002 \\
\hline HO natuur en techniek & 3 & laag & - \\
\hline HBO milieukunde en levensmiddelentechnologie & 10 & gemiddeld & - \\
\hline HBO laboratorium & 2 & laag & - \\
\hline HBO bouwkunde & 4 & gemiddeld & - \\
\hline HBO civiele techniek & 6 & gemiddeld & sterk stijgend \\
\hline HBO werktuigbouwkunde & 3 & laag & sterk dalend \\
\hline HBO elektrotechniek & 2 & laag & sterk dalend \\
\hline HBO informatica & 2 & laag & constant \\
\hline HBO vervoer en logistiek & 20 & gemiddeld & sterk stijgend \\
\hline WO wiskunde en natuurwetenschappen & 2 & laag & \\
\hline $\mathrm{HO}$ economie & 2 & laag & constant \\
\hline HBO accountancy en bedrijfseconomie & 3 & laag & - \\
\hline HBO commerciële economie & 1 & laag & sterk dalend \\
\hline HBO recht en bestuur & 0 & erg laag & sterk stijgend \\
\hline HBO secretariaat & 4 & gemiddeld & sterk stijgend \\
\hline HBO bedrijfskunde & 6 & gemiddeld & sterk stijgend \\
\hline WO econom(etr)ie & 0 & erg laag & sterk dalend \\
\hline WO bedrijfskunde & 1 & laag & sterk dalend \\
\hline WO rechten en bestuurskunde & 1 & laag & - \\
\hline HO onderwijs en sociaal-cultureel & 6 & gemiddeld & - \\
\hline HBO lerarenopleiding basisonderwijs & 6 & gemiddeld & sterk dalend \\
\hline HBO lerarenopleiding talen & 3 & laag & - \\
\hline HBO lerarenopleiding natuur en techniek & 1 & laag & sterk dalend \\
\hline HBO lerarenopleiding economie en maatschappij & 1 & erg laag & sterk dalend \\
\hline HBO lerarenopleiding lichamelijke opvoeding & 34 & hoog & sterk stijgend \\
\hline HBO lerarenopleiding expressie & 10 & gemiddeld & sterk stijgend \\
\hline HBO communicatie en journalistiek & 4 & gemiddeld & sterk stijgend \\
\hline HBO maatschappelijk werk en hulpverlening & 9 & gemiddeld & - \\
\hline HBO personeel en arbeid & 1 & laag & constant \\
\hline HBO uitvoerende en beeldende kunsten & 19 & gemiddeld & sterk stijgend \\
\hline WO letteren & 1 & erg laag & - \\
\hline WO sociale wetenschappen & 2 & laag & - \\
\hline HO medisch & 26 & gemiddeld & constant \\
\hline HBO verpleegkunde & 35 & hoog & - \\
\hline HBO (fysio)therapie & 32 & hoog & sterk stijgend \\
\hline HBO radiologie & 44 & hoog & sterk dalend \\
\hline WO (dier)geneeskunde & 9 & gemiddeld & sterk dalend \\
\hline \multicolumn{4}{|l|}{ Beroepen } \\
\hline Pedagogische beroepen & 5 & gemiddeld & - \\
\hline Leraar basisonderwijs & 4 & gemiddeld & - \\
\hline Docenten exacte, medische en verzorgende vakken (2e graads) & 1 & laag & - \\
\hline Docenten talen en expressie & 5 & gemiddeld & sterk stijgend \\
\hline Docenten letteren (1e graads) & 7 & gemiddeld & - \\
\hline Docenten sociale vakken (2e graads) & 31 & gemiddeld & sterk stijgend \\
\hline Onderwijskundigen en pedagogen & 0 & erg laag & - \\
\hline Sportinstructeurs & 38 & hoog & - \\
\hline Culturele beroepen & 6 & gemiddeld & dalend \\
\hline Bibliotheekassistenten & 5 & gemiddeld & sterk dalend \\
\hline Kunstenaars & 12 & gemiddeld & - \\
\hline Agrarische beroepen & 39 & hoog & - \\
\hline Agrarische arbeiders & 46 & hoog & constant \\
\hline Agrarische vakkrachten & 43 & hoog & - \\
\hline Technische, ambachts- en industrieberoepen & 40 & hoog & constant \\
\hline Productiemedewerkers & 43 & hoog & constant \\
\hline Laboranten & 13 & gemiddeld & sterk dalend \\
\hline Natuurwetenschappers & 1 & laag & constant \\
\hline Conciërges & 26 & gemiddeld & - \\
\hline
\end{tabular}


Tabel 14.4 (vervolg)

Percentage werkenden dat regelmatig kracht moet zetten tijdens het werk, gemiddelde 2001-2002

\begin{tabular}{|c|c|c|c|}
\hline & $\%$ & typering & trend 2000-2002 \\
\hline Hoofden technische dienst & 28 & gemiddeld & - \\
\hline Bouwvakkers & 71 & erg hoog & constant \\
\hline Aannemers en installateurs & 51 & erg hoog & stijgend \\
\hline Architecten en bouwkundig projectleiders & 5 & gemiddeld & sterk stijgend \\
\hline Weg- en waterbouwkundige arbeiders & 76 & erg hoog & dalend \\
\hline Weg- en waterbouwkundige vakkrachten & 20 & gemiddeld & - \\
\hline Metaalarbeiders & 53 & erg hoog & - \\
\hline Bankwerkers en lassers & 45 & hoog & stijgend \\
\hline Assembleurs & 41 & hoog & sterk dalend \\
\hline Monteurs & 46 & hoog & stijgend \\
\hline Werktuigbouwkundig ontwerpers en hoofden technische dienst & 5 & gemiddeld & sterk dalend \\
\hline Monteurs en controleurs elektrotechnische producten & 43 & hoog & sterk stijgend \\
\hline Elektromonteurs & 30 & gemiddeld & - \\
\hline Grafisch productiepersoneel & 24 & gemiddeld & - \\
\hline Grafische vakkrachten & 35 & hoog & constant \\
\hline Mechanisch operators & 44 & hoog & - \\
\hline Procesoperators & 29 & gemiddeld & - \\
\hline Confectie-arbeiders & 43 & hoog & stijgend \\
\hline Transportberoepen & 42 & hoog & constant \\
\hline Chauffeurs & 37 & hoog & constant \\
\hline Schippers en conducteurs & 29 & gemiddeld & - \\
\hline Vliegers, scheepskapiteins en leidinggevenden transport & 11 & gemiddeld & - \\
\hline Stewards & 42 & hoog & - \\
\hline Medische en paramedische beroepen & 34 & hoog & dalend \\
\hline Verpleeghulpen en leerling-verpleegkundigen & 70 & erg hoog & - \\
\hline Verplegenden en doktersassistenten & 43 & hoog & constant \\
\hline Therapeuten en verpleegkundigen & 44 & hoog & stijgend \\
\hline Artsen & 7 & gemiddeld & sterk dalend \\
\hline Apothekersassistenten en medisch laboranten & 6 & gemiddeld & - \\
\hline Medisch analisten & 23 & gemiddeld & sterk dalend \\
\hline Economisch-administratieve beroepen & 4 & gemiddeld & dalend \\
\hline Kantoorhulpen, inpakkers en colporteurs & 37 & hoog & - \\
\hline Bedrijfshoofden & 2 & laag & - \\
\hline Productieplanners & 8 & gemiddeld & sterk dalend \\
\hline Organisatie-adviseurs & 1 & laag & sterk dalend \\
\hline Organisatiedeskundigen & 0 & erg laag & - \\
\hline Receptionisten en administratieve employés & 5 & gemiddeld & sterk stijgend \\
\hline Boekhouders en secretaresses & 2 & laag & constant \\
\hline Assistent accountants & 0 & erg laag & sterk dalend \\
\hline Verzekeringsagenten & 2 & laag & - \\
\hline Commercieel employés & 4 & gemiddeld & stijgend \\
\hline Commercieel medewerkers & 3 & laag & sterk stijgend \\
\hline Juridisch en fiscaal medewerkers & 1 & laag & constant \\
\hline Juristen & 0 & erg laag & sterk dalend \\
\hline Administratieve transportemployés & 7 & gemiddeld & sterk stijgend \\
\hline Leidinggevenden & 2 & laag & sterk dalend \\
\hline Managers & 8 & gemiddeld & - \\
\hline Medisch secretaresses & 2 & laag & - \\
\hline Informatica beroepen & 2 & laag & sterk dalend \\
\hline Programmeurs & 4 & gemiddeld & sterk dalend \\
\hline Systeemanalisten & 1 & laag & sterk dalend \\
\hline Sociaal-culturele beroepen & 7 & gemiddeld & constant \\
\hline Activiteitenbegeleiders en medewerkers arbeidsbemiddeling & 15 & gemiddeld & stijgend \\
\hline Medewerkers sociaal-cultureel werk en personeel en arbeid & 4 & gemiddeld & \\
\hline Verzorgende en dienstverlenende beroepen & 38 & & constant \\
\hline Vakkenvullers & 61 & erg hoog & stijgend \\
\hline Interieurverzorgers & 34 & hoog & dalend \\
\hline Verkopers & 24 & gemiddeld & stijgend \\
\hline
\end{tabular}




\section{Totaal alle sectoren}

Tabel 14.4 (vervolg)

Percentage werkenden dat regelmatig kracht moet zetten tijdens het werk, gemiddelde 2001-2002

$\%$ typering trend 2000-2002

Winkeliers

Hulpkrachten horeca en verzorging

Ziekenverzorgenden

(a)

Verzorgend personeel

Bedrijfshoofden horeca

Bakkers en slagers

Openbare orde- en veiligheidsberoepen

Aspirant politieagenten, soldaten en beveiligingshulpkrachten

Politieagenten, onderofficieren en beveiligingsemployés

$\begin{array}{ll}\text { hoog } & \text { sterk stijgend } \\ \text { hoog } & \text { dalend } \\ \text { erg hoog } & \text { constant } \\ \text { erg hoog } & \text { stijgend } \\ \text { gemiddeld } & - \\ \text { hoog } & \text { sterk dalend } \\ \text { gemiddeld } & \text { sterk stijgend } \\ \text { gemiddeld } & - \\ \text { gemiddeld } & \text { sterk stijgend }\end{array}$

Specifieke groepen werkenden

Vrouwen

Jongeren

Ouderen

Allochtonen

gemiddeld constant

gemiddeld stijgend

gemiddeld stijgend

Totaal

gemiddeld dalend

22 gemiddeld constant

Bron: ROA/CBS 
Tabel 14.5

Percentage werkenden dat regelmatig onder hoge tijdsdruk werkt, gemiddelde 2001-2002

\begin{tabular}{|c|c|c|c|}
\hline & $\%$ & typering & trend 2000-2002 \\
\hline \multicolumn{4}{|l|}{ Opleidingen } \\
\hline Basisonderwijs & 20 & laag & dalend \\
\hline VMBO theorie & 23 & laag & dalend \\
\hline VMBO natuur en techniek & 21 & laag & dalend \\
\hline VMBO bouwtechniek & 18 & erg laag & dalend \\
\hline VMBO metaal: mechanische techniek & 22 & laag & constant \\
\hline VMBO voertuigentechniek & 19 & laag & sterk dalend \\
\hline VMBO elektrotechniek & 24 & laag & stijgend \\
\hline VMBO brood en banket & 28 & gemiddeld & - \\
\hline VMBO transport en logistiek & 28 & gemiddeld & sterk dalend \\
\hline VMBO beveiliging & 18 & erg laag & - \\
\hline VMBO economie & 23 & laag & - \\
\hline VMBO administratie, handel en mode & 21 & laag & dalend \\
\hline VMBO consumptief en levensmiddelentechniek & 29 & gemiddeld & - \\
\hline VMBO verzorging & 20 & laag & dalend \\
\hline HAVO/VWO & 28 & gemiddeld & dalend \\
\hline MBO natuur en techniek & 27 & gemiddeld & dalend \\
\hline MBO landbouw en veeteelt & 18 & erg laag & constant \\
\hline MBO milieu en groene ruimte & 16 & erg laag & - \\
\hline MBO laboratorium & 28 & gemiddeld & constant \\
\hline MBO bouw & 26 & gemiddeld & dalend \\
\hline MBO grond-, weg- en waterbouw & 31 & gemiddeld & constant \\
\hline MBO installatietechniek & 27 & gemiddeld & constant \\
\hline MBO werktuigbouw en mechanische techniek & 25 & laag & sterk dalend \\
\hline MBO fijnmechanische techniek & 26 & gemiddeld & - \\
\hline MBO motorvoertuigentechniek & 26 & gemiddeld & dalend \\
\hline MBO elektrotechniek & 28 & gemiddeld & constant \\
\hline MBO grafische techniek & 41 & hoog & constant \\
\hline MBO procestechniek & 20 & laag & - \\
\hline MBO brood en banket & 32 & gemiddeld & sterk dalend \\
\hline MBO levensmiddelentechniek/vleesverwerking & 24 & laag & dalend \\
\hline MBO vervoer en logistiek & 37 & gemiddeld & - \\
\hline MBO automatisering & 35 & gemiddeld & - \\
\hline MBO openbare orde en veiligheid & 33 & gemiddeld & constant \\
\hline MBO economie & 28 & gemiddeld & dalend \\
\hline MBO handel & 23 & laag & sterk dalend \\
\hline MBO secretariaat & 27 & gemiddeld & constant \\
\hline MBO toerisme en recreatie & 25 & laag & - \\
\hline MBO bedrijfskunde & 38 & gemiddeld & dalend \\
\hline MBO dienstverlening en gezondheidszorg & 32 & gemiddeld & dalend \\
\hline MBO sociaal-cultureel & 23 & laag & sterk dalend \\
\hline MBO verzorging & 35 & gemiddeld & sterk dalend \\
\hline MBO uiterlijke verzorging & 26 & gemiddeld & constant \\
\hline MBO horeca & 36 & gemiddeld & constant \\
\hline MBO beweging en therapie & 18 & erg laag & sterk dalend \\
\hline MBO geld, bank en belastingen & 29 & gemiddeld & sterk dalend \\
\hline MBO verzekeringswezen & 33 & gemiddeld & constant \\
\hline HO natuur en techniek & 35 & gemiddeld & dalend \\
\hline HBO milieukunde en levensmiddelentechnologie & 32 & gemiddeld & - \\
\hline HBO laboratorium & 31 & gemiddeld & dalend \\
\hline HBO bouwkunde & 38 & gemiddeld & constant \\
\hline HBO civiele techniek & 40 & hoog & dalend \\
\hline
\end{tabular}


Tabel 14.5 (vervolg)

Percentage werkenden dat regelmatig onder hoge tijdsdruk werkt, gemiddelde 2001-2002

\begin{tabular}{|c|c|c|c|}
\hline & $\%$ & typering & trend $2000-2002$ \\
\hline $\begin{array}{l}\text { HBO werktuigbouwkunde } \\
\text { HBO elektrotechniek } \\
\text { HBO informatica } \\
\text { HBO vervoer en logistiek } \\
\text { HBO openbare orde en veiligheid } \\
\text { WO landbouw en milieukunde } \\
\text { WO wiskunde en natuurwetenschappen } \\
\text { WO bouwkunde } \\
\text { WO civiele techniek } \\
\text { WO werktuigbouwkunde } \\
\text { WO elektrotechniek } \\
\text { WO informatica en bestuurlijke informatiekunde } \\
\text { HO economie } \\
\text { HBO accountancy en bedrijfseconomie } \\
\text { HBO commerciële economie } \\
\text { HBO toerisme en recreatie } \\
\text { HBO recht en bestuur } \\
\text { HBO secretariaat } \\
\text { HBO bedrijfskunde } \\
\text { WO econom(etr)ie } \\
\text { WO bedrijfsunde } \\
\text { WO accountancy en belastingen } \\
\text { WO rechten en bestuurskunde } \\
\text { HO onderwijs en sociaal-cultureel } \\
\text { HBO lerarenopleiding basisonderwijs } \\
\text { HBO lerarenopleiding talen } \\
\text { HBO lerarenopleiding natuur en techniek } \\
\text { HBO lerarenopleiding economie en maatschappij } \\
\text { HBO lerarenopleiding medisch en verzorging } \\
\text { HBO lerarenopleiding expressie } \\
\text { HBO tolk en vertaler } \\
\text { HBO communicatie en journalistiek } \\
\text { HBO maatschappelijk werk en hulpverlening } \\
\text { HBO personeel en arbeid } \\
\text { HBO bibliotheek en documentatie } \\
\text { HBO uitvoerende en beeldende kunsten } \\
\text { WO letteren } \\
\text { WO sociale wetenschappen } \\
\text { HO medisch } \\
\text { HBO verpleegkunde } \\
\text { HBO (fysio)therapie } \\
\text { HBO radiologie } \\
\text { WO (dier)geneeskunde } \\
\text { WO farmacie en medische biologie } \\
\text { W }\end{array}$ & $\begin{array}{l}37 \\
33 \\
35 \\
37 \\
45 \\
34 \\
37 \\
40 \\
39 \\
32 \\
34 \\
29 \\
40 \\
37 \\
36 \\
33 \\
41 \\
32 \\
38 \\
41 \\
48 \\
53 \\
44 \\
35 \\
31 \\
31 \\
33 \\
45 \\
38 \\
34 \\
34 \\
46 \\
34 \\
40 \\
25 \\
37 \\
42 \\
39 \\
43 \\
45 \\
28 \\
42 \\
53 \\
41\end{array}$ & $\begin{array}{l}\text { gemiddeld } \\
\text { gemiddeld } \\
\text { gemiddeld } \\
\text { gemiddeld } \\
\text { erg hoog } \\
\text { gemiddeld } \\
\text { gemiddeld } \\
\text { hoog } \\
\text { hoog } \\
\text { gemiddeld } \\
\text { gemiddeld } \\
\text { gemiddeld } \\
\text { hoog } \\
\text { gemiddeld } \\
\text { gemiddeld } \\
\text { gemiddeld } \\
\text { hoog } \\
\text { gemiddeld } \\
\text { gemiddeld } \\
\text { hoog } \\
\text { erg hoog } \\
\text { erg hoog } \\
\text { erg hoog } \\
\text { gemiddeld } \\
\text { gemiddeld } \\
\text { gemiddeld } \\
\text { gemiddeld } \\
\text { erg hoog } \\
\text { gemiddeld } \\
\text { gemiddeld } \\
\text { gemiddeld } \\
\text { erg hoog } \\
\text { gemiddeld } \\
\text { hoog } \\
\text { laag } \\
\text { gemiddeld } \\
\text { hoog } \\
\text { hoog } \\
\text { hoog } \\
\text { erg hoog } \\
\text { gemidddeld } \\
\text { hoog } \\
\text { erg hoog } \\
\text { hoog }\end{array}$ & $\begin{array}{l}\text { constant } \\
\text { sterk dalend } \\
\text { sterk dalend } \\
\text { dalend } \\
\text { sterk dalend } \\
\text { sterk dalend } \\
\text { constant } \\
\text { dalend } \\
\text { sterk stijgend } \\
\text { constant } \\
\text { sterk dalend } \\
\text { - } \\
\text { dalend } \\
\text { dalend } \\
\text { sterk dalend } \\
\text { stijgend } \\
\text { - } \\
\text { sterk stijgend } \\
\text { dalend } \\
\text { sterk dalend } \\
\text { constant } \\
\text { stijgend } \\
\text { - } \\
\text { dalend } \\
\text { dalend } \\
\text { sterk dalend } \\
\text { sterk dalend } \\
\text { constant } \\
\text { sterk dalend } \\
- \\
\text { sterk dalend } \\
\text { sterk dalend } \\
\text { constant } \\
\text { dalend } \\
- \\
\text { - } \\
\text { constant } \\
\text { dalend } \\
\text { constant } \\
\text { dalend } \\
\text { constant } \\
\text { - } \\
\text { constant } \\
\text { constant }\end{array}$ \\
\hline $\begin{array}{l}\text { Beroepen } \\
\text { Pedagogische beroepen } \\
\text { Leraar basisonderwijs } \\
\text { Docenten exacte, medische en verzorgende vakken (2e graads) } \\
\text { Docenten exacte, medische en verzorgende vakken (1e graads) } \\
\text { Docenten landbouw en techniek (2e graads) } \\
\text { Docenten economisch-administratieve vakken (2e graads) } \\
\text { Docenten economisch-administratieve vakken (1e graads) } \\
\text { Docenten talen en expressie } \\
\text { Docenten letteren (1e graads) } \\
\text { Docenten sociale vakken (2e graads) } \\
\text { Docenten sociale vakken (1e graads) } \\
\text { Onderwijskundig medewerkers }\end{array}$ & $\begin{array}{l}34 \\
32 \\
32 \\
43 \\
29 \\
48 \\
41 \\
34 \\
39 \\
31 \\
42 \\
34\end{array}$ & $\begin{array}{l}\text { gemiddeld } \\
\text { gemiddeld } \\
\text { gemiddeld } \\
\text { hoog } \\
\text { gemiddeld } \\
\text { erg hoog } \\
\text { hoog } \\
\text { gemiddeld } \\
\text { hoog } \\
\text { gemiddeld } \\
\text { hoog } \\
\text { gemiddeld }\end{array}$ & $\begin{array}{l}\text { dalend } \\
\text { dalend } \\
\text { sterk dalend } \\
\text { constant } \\
\text { constant } \\
\text { sterk stijgend } \\
\text { constant } \\
\text { - } \\
\text { sterk dalend } \\
\text { stijgend } \\
\text { - } \\
\text { dalend }\end{array}$ \\
\hline
\end{tabular}


Tabel 14.5 (vervolg)

Percentage werkenden dat regelmatig onder hoge tijdsdruk werkt, gemiddelde 2001-2002

\begin{tabular}{|c|c|c|c|}
\hline & $\%$ & typering & trend $2000-2002$ \\
\hline Onderwijskundigen en pedagogen & 40 & hoog & constant \\
\hline Culturele beroepen & 36 & gemiddeld & constant \\
\hline Bibliotheekassistenten & 15 & erg laag & - \\
\hline Grafisch ontwerpers & 39 & hoog & - \\
\hline Kunstenaars & 44 & erg hoog & - \\
\hline Journalisten & 63 & erg hoog & dalend \\
\hline Taalkundigen & 40 & hoog & - \\
\hline Agrarische beroepen & 15 & erg laag & - \\
\hline Agrarische arbeiders & 10 & erg laag & constant \\
\hline Milieuhygiënisten en agrarisch vertegenwoordigers & 33 & gemiddeld & sterk stijgend \\
\hline Technische, ambachts- en industrieberoepen & 25 & laag & dalend \\
\hline Productiemedewerkers & 22 & laag & - \\
\hline Laboranten & 20 & laag & - \\
\hline Natuurwetenschappers & 35 & gemiddeld & dalend \\
\hline Conciërges & 17 & erg laag & - \\
\hline Hoofden technische dienst & 30 & gemiddeld & - \\
\hline Werktuigbouwkundigen & 37 & gemiddeld & constant \\
\hline Bouwvakkers & 17 & erg laag & dalend \\
\hline Aannemers en installateurs & 28 & gemiddeld & sterk dalend \\
\hline Architecten en bouwkundig projectleiders & 45 & erg hoog & constant \\
\hline Weg- en waterbouwkundigen & 35 & gemiddeld & sterk dalend \\
\hline Weg- en waterbouwkundige arbeiders & 19 & laag & sterk dalend \\
\hline Weg- en waterbouwkundige vakkrachten & 24 & laag & - \\
\hline Weg- en waterbouwkundig ontwerpers en projectleiders & 38 & gemiddeld & sterk stijgend \\
\hline Metaalarbeiders & 19 & laag & constant \\
\hline Bankwerkers en lassers & 22 & laag & dalend \\
\hline Assembleurs & 21 & laag & dalend \\
\hline Monteurs & 25 & laag & sterk dalend \\
\hline Werktuigbouwkundig ontwerpers en hoofden technische dienst & 39 & hoog & sterk dalend \\
\hline Elektronicamonteurs & 28 & gemiddeld & constant \\
\hline Monteurs en controleurs elektrotechnische producten & 22 & laag & sterk dalend \\
\hline Elektromonteurs & 25 & laag & dalend \\
\hline Elektrotechnisch ontwerpers en bedrijfshoofden & 40 & hoog & - \\
\hline Elektrotechnici & 30 & gemiddeld & sterk dalend \\
\hline Grafisch productiepersoneel & 34 & gemiddeld & dalend \\
\hline Grafische vakkrachten & 42 & hoog & constant \\
\hline Mechanisch operators & 23 & laag & sterk dalend \\
\hline Procesoperators & 26 & gemiddeld & - \\
\hline Procestechnologen & 43 & hoog & constant \\
\hline Materiaalkundigen & 43 & hoog & - \\
\hline Confectie-arbeiders & 17 & erg laag & - \\
\hline Transportberoepen & 27 & gemiddeld & dalend \\
\hline Laders en lossers & 19 & laag & dalend \\
\hline Chauffeurs & 28 & gemiddeld & dalend \\
\hline Schippers en conducteurs & 37 & gemiddeld & sterk stijgend \\
\hline Vliegers, scheepskapiteins en leidinggevenden transport & 47 & erg hoog & constant \\
\hline Stewards & 43 & hoog & - \\
\hline Medische en paramedische beroepen & 39 & gemiddeld & dalend \\
\hline Verpleeghulpen en leerling-verpleegkundigen & 42 & hoog & - \\
\hline Verplegenden en doktersassistenten & 40 & hoog & dalend \\
\hline Therapeuten en verpleegkundigen & 36 & gemiddeld & constant \\
\hline Artsen & 49 & erg hoog & dalend \\
\hline Apothekersassistenten en medisch laboranten & 28 & gemiddeld & dalend \\
\hline Medisch analisten & 40 & hoog & constant \\
\hline Afdelingshoofden zorginstelling & 45 & erg hoog & sterk dalend \\
\hline Economisch-administratieve beroepen & 32 & gemiddeld & constant \\
\hline Kantoorhulpen, inpakkers en colporteurs & 23 & laag & sterk stijgend \\
\hline Bedrijfshoofden & 42 & hoog & constant \\
\hline
\end{tabular}


Tabel 14.5 (vervolg)

Percentage werkenden dat regelmatig onder hoge tijdsdruk werkt, gemiddelde 2001-2002

\begin{tabular}{|c|c|c|c|}
\hline & $\%$ & typering & trend $2000-2002$ \\
\hline Economen & 39 & hoog & - \\
\hline Productieplanners & 39 & hoog & dalend \\
\hline Organisatie-adviseurs & 36 & gemiddeld & constant \\
\hline Organisatiedeskundigen & 43 & hoog & sterk dalend \\
\hline Receptionisten en administratieve employés & 21 & laag & constant \\
\hline Boekhouders en secretaresses & 25 & laag & dalend \\
\hline Assistent accountants & 39 & hoog & - \\
\hline Accountants & 48 & erg hoog & dalend \\
\hline Verzekeringsagenten & 34 & gemiddeld & sterk stijgend \\
\hline Commercieel employés & 32 & gemiddeld & constant \\
\hline Commercieel medewerkers & 40 & hoog & dalend \\
\hline Technisch-commercieel employés & 26 & gemiddeld & - \\
\hline Technisch-bedrijfskundig medewerkers & 31 & gemiddeld & stijgend \\
\hline Juridisch en fiscaal medewerkers & 27 & gemiddeld & sterk dalend \\
\hline Juridisch, bestuurlijk medewerkers & 44 & erg hoog & sterk stijgend \\
\hline Juristen & 43 & hoog & dalend \\
\hline Administratieve transportemployés & 38 & gemiddeld & dalend \\
\hline Leidinggevenden & 47 & erg hoog & dalend \\
\hline Managers & 56 & erg hoog & constant \\
\hline Medisch secretaresses & 29 & gemiddeld & - \\
\hline Informatica beroepen & 32 & gemiddeld & dalend \\
\hline Systeemanalisten & 32 & gemiddeld & sterk dalend \\
\hline Informatici & 39 & gemiddeld & - \\
\hline Technisch systeemanalisten & 26 & gemiddeld & constant \\
\hline Sociaal-culturele beroepen & 32 & gemiddeld & sterk dalend \\
\hline Activiteitenbegeleiders en medewerkers arbeidsbemiddeling & 24 & laag & dalend \\
\hline Medewerkers sociaal-cultureel werk en personeel en arbeid & 37 & gemiddeld & dalend \\
\hline Hoofden sociaal-cultureel werk en personeel en arbeid & 51 & erg hoog & constant \\
\hline Sociaal-wetenschappelijk medewerkers & 35 & gemiddeld & sterk dalend \\
\hline Sociaal-wetenschappelijk onderzoekers & 32 & gemiddeld & sterk dalend \\
\hline Verzorgende en dienstverlenende beroepen & 24 & laag & dalend \\
\hline Vakkenvullers & 15 & erg laag & sterk stijgend \\
\hline Interieurverzorgers & 24 & laag & constant \\
\hline Verkopers & 12 & erg laag & sterk dalend \\
\hline Winkeliers & 26 & gemiddeld & sterk dalend \\
\hline Hulpkrachten horeca en verzorging & 28 & gemiddeld & dalend \\
\hline Ziekenverzorgenden & 45 & erg hoog & sterk dalend \\
\hline Verzorgend personeel & 29 & gemiddeld & dalend \\
\hline Bedrijfshoofden horeca & 42 & hoog & - \\
\hline Openbare orde- en veiligheidsberoepen & 26 & gemiddeld & constant \\
\hline Aspirant politieagenten, soldaten en beveiligingshulpkrachten & 19 & laag & constant \\
\hline Politieagenten, onderofficieren en beveiligingsemployés & 32 & gemiddeld & constant \\
\hline \multicolumn{4}{|l|}{ Specifieke groepen werkenden } \\
\hline Vrouwen & 28 & gemiddeld & dalend \\
\hline Jongeren & 23 & laag & dalend \\
\hline Ouderen & 32 & gemiddeld & dalend \\
\hline Allochtonen & 28 & gemiddeld & dalend \\
\hline Totaal & 29 & gemiddeld & dalend \\
\hline
\end{tabular}

Bron: ROA/CBS 
Tabel 14.6

Percentage werkenden dat regelmatig beeldschermwerk verricht, gemiddelde 2001-2002

\begin{tabular}{|c|c|c|c|}
\hline & $\%$ & typering & trend $2000-2002$ \\
\hline \multicolumn{4}{|l|}{ Opleidingen } \\
\hline Basisonderwijs & 14 & laag & constant \\
\hline VMBO theorie & 43 & gemiddeld & constant \\
\hline VMBO natuur en techniek & 14 & laag & - \\
\hline VMBO landbouw en natuurlijke omgeving & 8 & laag & - \\
\hline VMBO bouwtechniek & 9 & laag & - \\
\hline VMBO metaal: mechanische techniek & 13 & laag & dalend \\
\hline VMBO voertuigentechniek & 16 & laag & sterk stijgend \\
\hline VMBO elektrotechniek & 27 & gemiddeld & sterk stijgend \\
\hline VMBO transport en logistiek & 10 & laag & - \\
\hline VMBO beveiliging & 26 & gemiddeld & - \\
\hline VMBO economie & 35 & gemiddeld & - \\
\hline VMBO administratie, handel en mode & 42 & gemiddeld & stijgend \\
\hline VMBO consumptief en levensmiddelentechniek & 18 & laag & - \\
\hline VMBO verzorging & 16 & laag & sterk stijgend \\
\hline HAVO/VWO & 63 & gemiddeld & constant \\
\hline MBO natuur en techniek & 35 & gemiddeld & stijgend \\
\hline MBO landbouw en veeteelt & 23 & laag & - \\
\hline MBO milieu en groene ruimte & 12 & laag & sterk dalend \\
\hline MBO laboratorium & 58 & gemiddeld & - \\
\hline MBO bouw & 22 & laag & - \\
\hline MBO grond-, weg- en waterbouw & 35 & gemiddeld & - \\
\hline MBO installatietechniek & 15 & laag & sterk dalend \\
\hline MBO werktuigbouw en mechanische techniek & 35 & gemiddeld & - \\
\hline MBO fijnmechanische techniek & 32 & gemiddeld & - \\
\hline MBO motorvoertuigentechniek & 25 & gemiddeld & sterk stijgend \\
\hline MBO elektrotechniek & 47 & gemiddeld & - \\
\hline MBO grafische techniek & 57 & gemiddeld & sterk stijgend \\
\hline MBO procestechniek & 56 & gemiddeld & - \\
\hline MBO brood en banket & 21 & laag & sterk stijgend \\
\hline MBO levensmiddelentechniek/vleesverwerking & 27 & gemiddeld & sterk stijgend \\
\hline MBO vervoer en logistiek & 49 & gemiddeld & - \\
\hline MBO automatisering & 89 & hoog & constant \\
\hline MBO openbare orde en veiligheid & 62 & gemiddeld & - \\
\hline MBO economie & 70 & gemiddeld & constant \\
\hline MBO administratie & 83 & hoog & constant \\
\hline MBO handel & 45 & gemiddeld & stijgend \\
\hline MBO secretariaat & 87 & hoog & constant \\
\hline MBO toerisme en recreatie & 83 & hoog & constant \\
\hline MBO bedrijfskunde & 69 & gemiddeld & stijgend \\
\hline MBO dienstverlening en gezondheidszorg & 29 & gemiddeld & stijgend \\
\hline MBO dokters-, tandarts- en dierenartsassistent & 64 & gemiddeld & - \\
\hline MBO apothekersassistent & 77 & hoog & stijgend \\
\hline MBO verpleging & 22 & laag & sterk stijgend \\
\hline MBO sociaal-cultureel & 35 & gemiddeld & constant \\
\hline MBO verzorging & 18 & laag & sterk stijgend \\
\hline MBO uiterlijke verzorging & 28 & gemiddeld & dalend \\
\hline MBO horeca & 33 & gemiddeld & constant \\
\hline MBO beweging en therapie & 29 & gemiddeld & sterk dalend \\
\hline MBO geld, bank en belastingen & 87 & hoog & constant \\
\hline MBO verzekeringswezen & 87 & hoog & dalend \\
\hline HO natuur en techniek & 80 & hoog & stijgend \\
\hline
\end{tabular}


Tabel 14.6 (vervolg)

Percentage werkenden dat regelmatig beeldschermwerk verricht, gemiddelde 2001-2002

\begin{tabular}{|c|c|c|c|}
\hline & $\%$ & typering & trend 2000-2002 \\
\hline HBO landbouw en veeteelt & 71 & gemiddeld & stijgend \\
\hline HBO milieukunde en levensmiddelentechnologie & 88 & hoog & stijgend \\
\hline HBO laboratorium & 59 & gemiddeld & sterk stijgend \\
\hline HBO bouwkunde & 69 & gemiddeld & stijgend \\
\hline HBO civiele techniek & 80 & hoog & - \\
\hline HBO werktuigbouwkunde & 85 & hoog & stijgend \\
\hline HBO elektrotechniek & 84 & hoog & stijgend \\
\hline HBO informatica & 91 & erg hoog & constant \\
\hline HBO chemische technologie & 81 & hoog & sterk dalend \\
\hline HBO vervoer en logistiek & 67 & gemiddeld & constant \\
\hline HBO openbare orde en veiligheid & 71 & gemiddeld & - \\
\hline WO landbouw en milieukunde & 88 & hoog & sterk stijgend \\
\hline WO wiskunde en natuurwetenschappen & 80 & hoog & stijgend \\
\hline WO bouwkunde & 74 & gemiddeld & constant \\
\hline WO civiele techniek & 84 & hoog & stijgend \\
\hline WO werktuigbouwkunde & 77 & hoog & - \\
\hline WO elektrotechniek & 88 & hoog & constant \\
\hline WO informatica en bestuurlijke informatiekunde & 85 & hoog & sterk dalend \\
\hline HO economie & 86 & hoog & constant \\
\hline HBO accountancy en bedrijfseconomie & 93 & erg hoog & constant \\
\hline HBO commerciële economie & 87 & hoog & constant \\
\hline HBO toerisme en recreatie & 86 & hoog & stijgend \\
\hline HBO recht en bestuur & 89 & hoog & constant \\
\hline HBO secretariaat & 91 & erg hoog & constant \\
\hline HBO bedrijfskunde & 81 & hoog & constant \\
\hline WO econom(etr)ie & 86 & hoog & stijgend \\
\hline WO bedrijfskunde & 81 & hoog & constant \\
\hline WO accountancy en belastingen & 89 & hoog & constant \\
\hline WO rechten en bestuurskunde & 85 & hoog & stijgend \\
\hline $\mathrm{HO}$ onderwijs en sociaal-cultureel & 47 & gemiddeld & constant \\
\hline HBO lerarenopleiding basisonderwijs & 20 & laag & dalend \\
\hline HBO lerarenopleiding talen & 40 & gemiddeld & sterk dalend \\
\hline HBO lerarenopleiding natuur en techniek & 39 & gemiddeld & dalend \\
\hline HBO lerarenopleiding economie en maatschappij & 41 & gemiddeld & stijgend \\
\hline HBO lerarenopleiding medisch en verzorging & 34 & gemiddeld & stijgend \\
\hline HBO lerarenopleiding expressie & 30 & gemiddeld & sterk dalend \\
\hline HBO tolk en vertaler & 66 & gemiddeld & sterk dalend \\
\hline HBO communicatie en journalistiek & 75 & gemiddeld & constant \\
\hline HBO maatschappelijk werk en hulpverlening & 59 & gemiddeld & sterk stijgend \\
\hline HBO personeel en arbeid & 78 & hoog & dalend \\
\hline HBO bibliotheek en documentatie & 84 & hoog & - \\
\hline HBO uitvoerende en beeldende kunsten & 50 & gemiddeld & - \\
\hline WO letteren & 72 & gemiddeld & sterk stijgend \\
\hline WO sociale wetenschappen & 70 & gemiddeld & stijgend \\
\hline HO medisch & 40 & gemiddeld & sterk stijgend \\
\hline HBO verpleegkunde & 33 & gemiddeld & sterk stijgend \\
\hline HBO (fysio)therapie & 29 & gemiddeld & sterk stijgend \\
\hline HBO voeding & 82 & hoog & sterk stijgend \\
\hline HBO radiologie & 69 & gemiddeld & - \\
\hline WO (dier)geneeskunde & 43 & gemiddeld & sterk stijgend \\
\hline WO farmacie en medische biologie & 85 & hoog & sterk stijgend \\
\hline \multicolumn{4}{|l|}{ Beroepen } \\
\hline Pedagogische beroepen & 24 & gemiddeld & constant \\
\hline Leraar basisonderwijs & 12 & laag & - \\
\hline Docenten exacte, medische en verzorgende vakken (2e graads) & 31 & gemiddeld & - \\
\hline Docenten exacte, medische en verzorgende vakken ( $1 \mathrm{e}$ graads) & 38 & gemiddeld & sterk stijgend \\
\hline Docenten landbouw en techniek (2e graads) & 26 & gemiddeld & sterk dalend \\
\hline
\end{tabular}


Tabel 14.6 (vervolg)

Percentage werkenden dat regelmatig beeldschermwerk verricht, gemiddelde 2001-2002

\begin{tabular}{|c|c|c|c|}
\hline & $\%$ & typering & trend $2000-2002$ \\
\hline Docenten economisch-administratieve vakken (2e graads) & 68 & gemiddeld & sterk stijgend \\
\hline Docenten economisch-administratieve vakken (1e graads) & 61 & gemiddeld & - \\
\hline Docenten talen en expressie & 16 & laag & sterk dalend \\
\hline Docenten letteren (1e graads) & 23 & laag & sterk dalend \\
\hline Docenten sociale vakken (1e graads) & 39 & gemiddeld & - \\
\hline Onderwijskundig medewerkers & 68 & gemiddeld & constant \\
\hline Onderwijskundigen en pedagogen & 65 & gemiddeld & constant \\
\hline Culturele beroepen & 79 & hoog & stijgend \\
\hline Tolken, vertalers en schrijvers & 88 & hoog & sterk stijgend \\
\hline Bibliotheekassistenten & 81 & hoog & constant \\
\hline Bibliothecarissen & 88 & hoog & - \\
\hline Grafisch ontwerpers & 96 & erg hoog & sterk stijgend \\
\hline Kunstenaars & 64 & gemiddeld & sterk stijgend \\
\hline Journalisten & 93 & erg hoog & stijgend \\
\hline Taalkundigen & 80 & hoog & - \\
\hline Agrarische beroepen & 15 & laag & - \\
\hline Agrarische arbeiders & 2 & erg laag & sterk stijgend \\
\hline Milieuhygiënisten en agrarisch vertegenwoordigers & 68 & gemiddeld & - \\
\hline Agrarische bedrijfshoofden & 41 & gemiddeld & sterk stijgend \\
\hline Technische, ambachts- en industrieberoepen & 25 & gemiddeld & stijgend \\
\hline Productiemedewerkers & 10 & laag & sterk stijgend \\
\hline Laboranten & 58 & gemiddeld & constant \\
\hline Technisch analisten & 66 & gemiddeld & dalend \\
\hline Natuurwetenschappers & 76 & gemiddeld & constant \\
\hline Conciërges & 15 & laag & sterk stijgend \\
\hline Hoofden technische dienst & 43 & gemiddeld & constant \\
\hline Werktuigbouwkundigen & 92 & erg hoog & - \\
\hline Bouwvakkers & 1 & erg laag & stijgend \\
\hline Aannemers en installateurs & 20 & laag & sterk dalend \\
\hline Architecten en bouwkundig projectleiders & 63 & gemiddeld & constant \\
\hline Weg- en waterbouwkundigen & 77 & hoog & stijgend \\
\hline Weg- en waterbouwkundige arbeiders & 1 & erg laag & sterk dalend \\
\hline Weg- en waterbouwkundige vakkrachten & 29 & gemiddeld & - \\
\hline Weg- en waterbouwkundig ontwerpers en projectleiders & 82 & hoog & stijgend \\
\hline Metaalarbeiders & 8 & laag & sterk dalend \\
\hline Bankwerkers en lassers & 14 & laag & sterk dalend \\
\hline Bedrijfshoofden metaalbewerking & - & - & - \\
\hline Assembleurs & 7 & erg laag & sterk stijgend \\
\hline Monteurs & 19 & laag & - \\
\hline Werktuigbouwkundig ontwerpers en hoofden technische dienst & 76 & gemiddeld & - \\
\hline Elektronicamonteurs & 67 & gemiddeld & sterk dalend \\
\hline Monteurs en controleurs elektrotechnische producten & 29 & gemiddeld & - \\
\hline Elektromonteurs & 28 & gemiddeld & sterk stijgend \\
\hline Elektrotechnisch ontwerpers en bedrijfshoofden & 77 & hoog & - \\
\hline Elektrotechnici & 94 & erg hoog & constant \\
\hline Grafisch productiepersoneel & 57 & gemiddeld & - \\
\hline Grafische vakkrachten & 30 & gemiddeld & sterk dalend \\
\hline Mechanisch operators & 15 & laag & dalend \\
\hline Procesoperators & 44 & gemiddeld & sterk stijgend \\
\hline Procestechnologen & 79 & hoog & - \\
\hline Materiaalkundigen & 72 & gemiddeld & - \\
\hline Transportberoepen & 13 & laag & - \\
\hline Laders en lossers & 21 & laag & - \\
\hline Chauffeurs & 3 & erg laag & sterk stijgend \\
\hline Schippers en conducteurs & 36 & gemiddeld & constant \\
\hline Vliegers, scheepskapiteins en leidinggevenden transport & 70 & gemiddeld & sterk stijgend \\
\hline Medische en paramedische beroepen & 33 & gemiddeld & sterk stijgend \\
\hline Verpleeghulpen en leerling-verpleegkundigen & 5 & erg laag & sterk stijgend \\
\hline
\end{tabular}


Tabel 14.6 (vervolg)

Percentage werkenden dat regelmatig beeldschermwerk verricht, gemiddelde 2001-2002

\begin{tabular}{|c|c|c|c|}
\hline & $\%$ & typering & trend $2000-2002$ \\
\hline Verplegenden en doktersassistenten & 30 & gemiddeld & - \\
\hline Therapeuten en verpleegkundigen & 16 & laag & sterk stijgend \\
\hline Artsen & 46 & gemiddeld & - \\
\hline Apothekersassistenten en medisch laboranten & 56 & gemiddeld & stijgend \\
\hline Medisch analisten & 64 & gemiddeld & sterk stijgend \\
\hline Apothekers & 75 & gemiddeld & - \\
\hline Afdelingshoofden zorginstelling & 66 & gemiddeld & sterk stijgend \\
\hline Economisch-administratieve beroepen & 83 & hoog & constant \\
\hline Kantoorhulpen, inpakkers en colporteurs & 6 & erg laag & - \\
\hline Ondersteunende administratieve hulpkrachten & 46 & gemiddeld & constant \\
\hline Bedrijfshoofden & 80 & hoog & - \\
\hline Economen & 95 & erg hoog & constant \\
\hline Productieplanners & 86 & hoog & stijgend \\
\hline Organisatie-adviseurs & 85 & hoog & constant \\
\hline Organisatiedeskundigen & 87 & hoog & constant \\
\hline Receptionisten en administratieve employés & 85 & hoog & constant \\
\hline Boekhouders en secretaresses & 94 & erg hoog & constant \\
\hline Assistent accountants & 94 & erg hoog & constant \\
\hline Accountants & 95 & erg hoog & constant \\
\hline Verzekeringsagenten & 92 & erg hoog & constant \\
\hline Commercieel employés & 82 & hoog & constant \\
\hline Commercieel medewerkers & 84 & hoog & constant \\
\hline Technisch-commercieel employés & 77 & hoog & sterk stijgend \\
\hline Technisch-bedrijfskundig medewerkers & 78 & hoog & dalend \\
\hline Juridisch en fiscaal medewerkers & 88 & hoog & constant \\
\hline Juridisch, bestuurlijk medewerkers & 88 & hoog & constant \\
\hline Juristen & 90 & hoog & constant \\
\hline Administratieve transportemployés & 80 & hoog & constant \\
\hline Leidinggevenden & 67 & gemiddeld & stijgend \\
\hline Managers & 64 & gemiddeld & sterk stijgend \\
\hline Medisch secretaresses & 90 & hoog & constant \\
\hline Informatica beroepen & 96 & erg hoog & constant \\
\hline Programmeurs & 98 & erg hoog & constant \\
\hline Systeemanalisten & 97 & erg hoog & constant \\
\hline Informatici & 91 & erg hoog & constant \\
\hline Technisch systeemanalisten & 96 & erg hoog & stijgend \\
\hline Sociaal-culturele beroepen & 58 & gemiddeld & stijgend \\
\hline Activiteitenbegeleiders en medewerkers arbeidsbemiddeling & 42 & gemiddeld & - \\
\hline Medewerkers sociaal-cultureel werk en personeel en arbeid & 64 & gemiddeld & stijgend \\
\hline Hoofden sociaal-cultureel werk en personeel en arbeid & 69 & gemiddeld & sterk stijgend \\
\hline Sociaal-wetenschappelijk medewerkers & 70 & gemiddeld & dalend \\
\hline Sociaal-wetenschappelijk onderzoekers & 74 & gemiddeld & constant \\
\hline Verzorgende en dienstverlenende beroepen & 12 & laag & constant \\
\hline Vakkenvullers & 19 & laag & sterk stijgend \\
\hline Interieurverzorgers & 2 & erg laag & sterk dalend \\
\hline Verkopers & 19 & laag & constant \\
\hline Winkeliers & 37 & gemiddeld & constant \\
\hline Hulpkrachten horeca en verzorging & 2 & erg laag & - \\
\hline Ziekenverzorgenden & 6 & erg laag & sterk stijgend \\
\hline Verzorgend personeel & 7 & erg laag & constant \\
\hline Bedrijfshoofden horeca & 27 & gemiddeld & - \\
\hline Openbare orde- en veiligheidsberoepen & & & \\
\hline Aspirant politieagenten, soldaten en beveiligingshulpkrachten & 33 & gemiddeld & - \\
\hline Politieagenten, onderofficieren en beveiligingsemployés & 69 & gemiddeld & - \\
\hline Politie-inspecteurs en officieren & 88 & hoog & constant \\
\hline
\end{tabular}


Totaal alle sectoren

Tabel 14.6 (vervolg)

Percentage werkenden dat regelmatig beeldschermwerk verricht, gemiddelde 2001-2002

$\% \quad$ typering trend $2000-2002$

Specifieke groepen werkenden

Vrouwen

48 gemiddeld stijgend

Jongeren

gemiddeld

constant

Ouderen

44 gemiddeld

stijgend

Allochtonen

34 gemiddeld

-

Totaal

46 gemiddeld

stijgend

Bron: ROA/CBS 
Tabel 14.7

Percentage werkenden dat deelneemt aan scholingstrajecten korter dan 6 maanden, gemiddelde 2001-2002

\begin{tabular}{|c|c|c|c|}
\hline & $\%$ & typering & trend 2000-2002 \\
\hline \multicolumn{4}{|l|}{ Opleidingen } \\
\hline Basisonderwijs & 3 & laag & sterk dalend \\
\hline VMBO theorie & 3 & laag & sterk dalend \\
\hline VMBO natuur en techniek & 3 & laag & - \\
\hline VMBO landbouw en natuurlijke omgeving & 3 & laag & - \\
\hline VMBO bouwtechniek & 3 & laag & constant \\
\hline VMBO metaal: mechanische techniek & 4 & gemiddeld & sterk dalend \\
\hline VMBO voertuigentechniek & 3 & laag & sterk stijgend \\
\hline VMBO elektrotechniek & 4 & gemiddeld & - \\
\hline VMBO transport en logistiek & 2 & laag & constant \\
\hline VMBO beveiliging & 4 & gemiddeld & sterk stijgend \\
\hline VMBO economie & 3 & laag & sterk dalend \\
\hline VMBO administratie, handel en mode & 4 & gemiddeld & sterk dalend \\
\hline VMBO consumptief en levensmiddelentechniek & 3 & laag & sterk dalend \\
\hline VMBO verzorging & 3 & laag & - \\
\hline HAVO/VWO & 4 & gemiddeld & sterk dalend \\
\hline MBO natuur en techniek & 4 & gemiddeld & sterk dalend \\
\hline MBO landbouw en veeteelt & 3 & laag & sterk dalend \\
\hline MBO milieu en groene ruimte & 4 & gemiddeld & - \\
\hline MBO laboratorium & 3 & laag & - \\
\hline MBO bouw & 4 & gemiddeld & - \\
\hline MBO grond-, weg- en waterbouw & 4 & gemiddeld & sterk dalend \\
\hline MBO installatietechniek & 4 & gemiddeld & - \\
\hline MBO werktuigbouw en mechanische techniek & 4 & gemiddeld & sterk dalend \\
\hline MBO motorvoertuigentechniek & 5 & gemiddeld & constant \\
\hline MBO elektrotechniek & 6 & hoog & sterk dalend \\
\hline MBO grafische techniek & 2 & laag & sterk dalend \\
\hline MBO procestechniek & 5 & gemiddeld & - \\
\hline MBO levensmiddelentechniek/vleesverwerking & 3 & laag & sterk dalend \\
\hline MBO vervoer en logistiek & 4 & gemiddeld & - \\
\hline MBO automatisering & 7 & hoog & sterk dalend \\
\hline MBO openbare orde en veiligheid & 7 & hoog & constant \\
\hline MBO economie & 5 & gemiddeld & dalend \\
\hline MBO administratie & 5 & gemiddeld & - \\
\hline MBO handel & 4 & gemiddeld & sterk dalend \\
\hline MBO secretariaat & 5 & gemiddeld & - \\
\hline MBO toerisme en recreatie & 4 & gemiddeld & - \\
\hline MBO bedrijfskunde & 4 & gemiddeld & sterk dalend \\
\hline MBO dienstverlening en gezondheidszorg & 4 & gemiddeld & dalend \\
\hline MBO dokters-, tandarts- en dierenartsassistent & 2 & laag & - \\
\hline MBO apothekersassistent & 9 & erg hoog & sterk dalend \\
\hline MBO verpleging & 5 & gemiddeld & - \\
\hline MBO sociaal-cultureel & 4 & gemiddeld & - \\
\hline MBO verzorging & 5 & gemiddeld & constant \\
\hline MBO uiterlijke verzorging & 3 & laag & - \\
\hline MBO horeca & 4 & gemiddeld & sterk dalend \\
\hline MBO beweging en therapie & 3 & laag & sterk stijgend \\
\hline MBO geld, bank en belastingen & 8 & erg hoog & - \\
\hline MBO verzekeringswezen & 4 & gemiddeld & - \\
\hline HO natuur en techniek & 5 & gemiddeld & sterk dalend \\
\hline HBO milieukunde en levensmiddelentechnologie & 7 & hoog & sterk dalend \\
\hline HBO laboratorium & 3 & laag & sterk dalend \\
\hline HBO bouwkunde & 5 & gemiddeld & sterk stijgend \\
\hline HBO civiele techniek & 5 & gemiddeld & sterk dalend \\
\hline HBO werktuigbouwkunde & 5 & gemiddeld & - \\
\hline HBO elektrotechniek & 5 & gemiddeld & sterk dalend \\
\hline HBO informatica & 8 & erg hoog & sterk dalend \\
\hline HBO vervoer en logistiek & 5 & gemiddeld & sterk dalend \\
\hline
\end{tabular}


Totaal alle sectoren

Tabel 14.7 (vervolg)

Percentage werkenden dat deelneemt aan scholingstrajecten korter dan 6 maanden, gemiddelde 2001-2002

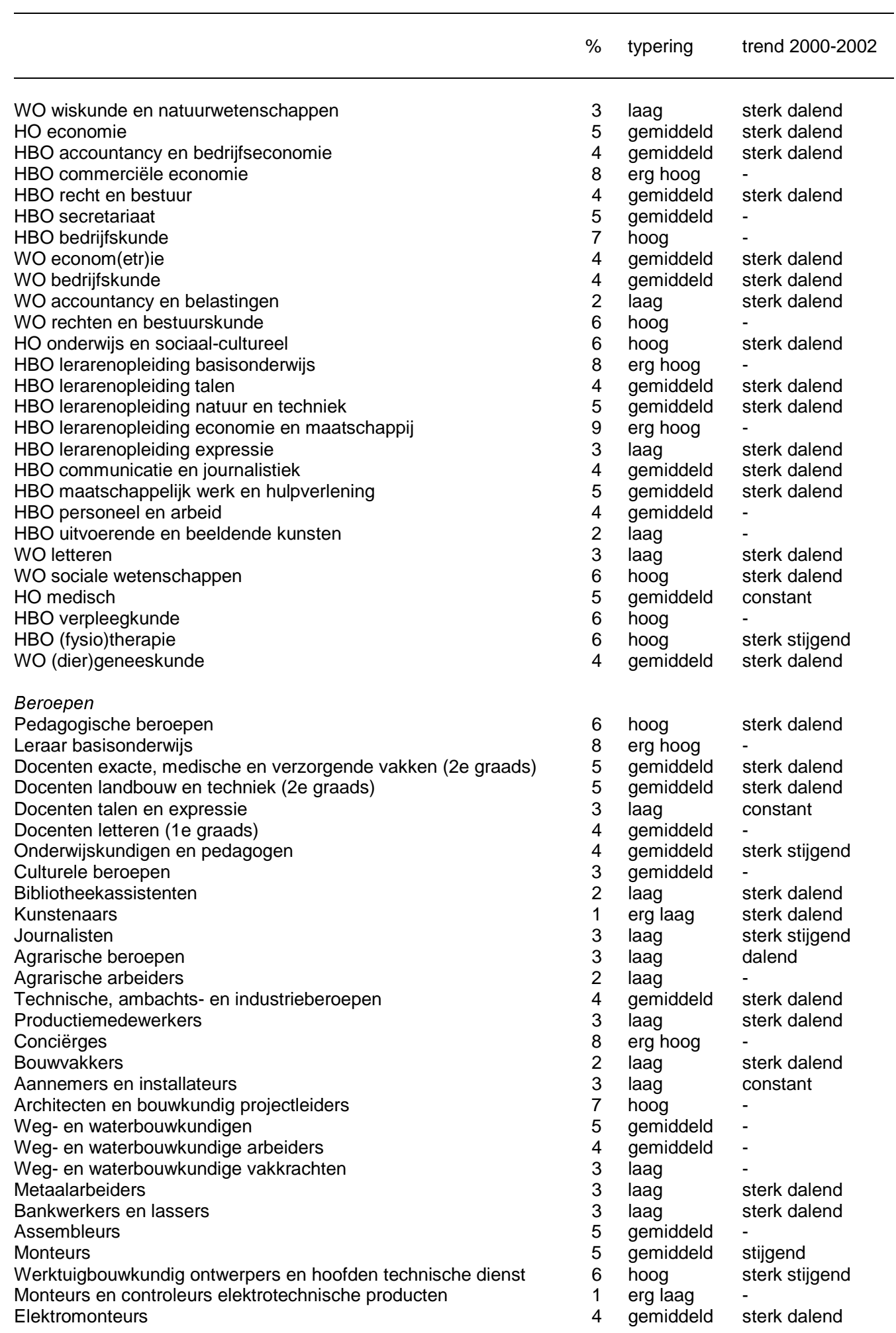


Tabel 14.7 (vervolg)

Percentage werkenden dat deelneemt aan scholingstrajecten korter dan 6 maanden, gemiddelde 2001-2002

\begin{tabular}{|c|c|c|c|}
\hline & $\%$ & typering & trend $2000-2002$ \\
\hline Grafisch productiepersoneel & 2 & laag & - \\
\hline Grafische vakkrachten & 1 & erg laag & - \\
\hline Mechanisch operators & 2 & laag & sterk dalend \\
\hline Procesoperators & 5 & gemiddeld & - \\
\hline Confectie-arbeiders & 2 & laag & sterk stijgend \\
\hline Transportberoepen & 2 & laag & sterk dalend \\
\hline Laders en lossers & 2 & laag & - \\
\hline Chauffeurs & 2 & laag & sterk dalend \\
\hline Vliegers, scheepskapiteins en leidinggevenden transport & 4 & gemiddeld & - \\
\hline Medische en paramedische beroepen & 5 & gemiddeld & dalend \\
\hline Verpleeghulpen en leerling-verpleegkundigen & 3 & laag & - \\
\hline Verplegenden en doktersassistenten & 5 & gemiddeld & sterk stijgend \\
\hline Therapeuten en verpleegkundigen & 6 & gemiddeld & sterk stijgend \\
\hline Artsen & 3 & laag & sterk dalend \\
\hline Apothekersassistenten en medisch laboranten & 7 & hoog & sterk dalend \\
\hline Medisch analisten & 3 & laag & sterk stijgend \\
\hline Economisch-administratieve beroepen & 5 & gemiddeld & sterk dalend \\
\hline Kantoorhulpen, inpakkers en colporteurs & 2 & laag & sterk dalend \\
\hline Bedrijfshoofden & 6 & hoog & sterk stijgend \\
\hline Productieplanners & 5 & gemiddeld & sterk dalend \\
\hline Organisatie-adviseurs & 4 & gemiddeld & - \\
\hline Organisatiedeskundigen & 3 & laag & - \\
\hline Receptionisten en administratieve employés & 3 & laag & sterk dalend \\
\hline Boekhouders en secretaresses & 4 & gemiddeld & - \\
\hline Assistent accountants & 4 & gemiddeld & sterk dalend \\
\hline Accountants & 4 & gemiddeld & constant \\
\hline Verzekeringsagenten & 6 & hoog & dalend \\
\hline Commercieel employés & 6 & hoog & sterk dalend \\
\hline Commercieel medewerkers & 9 & erg hoog & constant \\
\hline Juridisch en fiscaal medewerkers & 7 & hoog & sterk stijgend \\
\hline Juridisch, bestuurlijk medewerkers & 4 & gemiddeld & - \\
\hline Juristen & 4 & gemiddeld & sterk dalend \\
\hline Administratieve transportemployés & 6 & hoog & - \\
\hline Leidinggevenden & 4 & gemiddeld & sterk dalend \\
\hline Managers & 6 & hoog & - \\
\hline Medisch secretaresses & 2 & laag & sterk dalend \\
\hline Informatica beroepen & 8 & erg hoog & sterk dalend \\
\hline Programmeurs & 9 & erg hoog & sterk dalend \\
\hline Systeemanalisten & 8 & erg hoog & - \\
\hline Informatici & 8 & erg hoog & - \\
\hline Sociaal-culturele beroepen & 6 & hoog & sterk dalend \\
\hline Activiteitenbegeleiders en medewerkers arbeidsbemiddeling & 5 & gemiddeld & sterk dalend \\
\hline Medewerkers sociaal-cultureel werk en personeel en arbeid & 6 & hoog & constant \\
\hline Sociaal-wetenschappelijk onderzoekers & 7 & hoog & - \\
\hline Verzorgende en dienstverlenende beroepen & 3 & laag & sterk dalend \\
\hline Vakkenvullers & 2 & laag & sterk dalend \\
\hline Interieurverzorgers & 2 & laag & - \\
\hline Verkopers & 2 & laag & sterk dalend \\
\hline Winkeliers & 3 & laag & sterk dalend \\
\hline Hulpkrachten horeca en verzorging & 3 & laag & sterk dalend \\
\hline Ziekenverzorgenden & 4 & gemiddeld & sterk stijgend \\
\hline Verzorgend personeel & 4 & gemiddeld & sterk stijgend \\
\hline Bedrijfshoofden horeca & 5 & gemiddeld & - \\
\hline Openbare orde- en veiligheidsberoepen & 10 & erg hoog & sterk stijgend \\
\hline Aspirant politieagenten, soldaten en beveiligingshulpkrachten & 10 & erg hoog & sterk stijgend \\
\hline Politieagenten, onderofficieren en beveiligingsemployés & 10 & erg hoog & sterk stijgend \\
\hline
\end{tabular}


Totaal alle sectoren

Tabel 14.7 (vervolg)

Percentage werkenden dat deelneemt aan scholingstrajecten korter dan 6 maanden, gemiddelde 2001-2002

$\% \quad$ typering trend $2000-2002$

Specifieke groepen werkenden

Vrouwen

Jongeren

Ouderen

4 gemiddeld

Allochtonen

laag

sterk dalend

3 laag

constant

Totaal

4 gemiddeld sterk dalend

Bron: ROA/CBS 
Tabel 14.8

Percentage werkenden dat deelneemt aan scholingstrajecten van 6 maanden of langer, gemiddelde 20012002

$\% \quad$ typering trend 2000-2002

Opleidingen

Basisonderwijs

VMBO theorie

VMBO natuur en techniek

VMBO landbouw en natuurlijke omgeving

VMBO bouwtechniek

VMBO metaal: mechanische techniek

VMBO voertuigentechniek

VMBO elektrotechniek

VMBO transport en logistiek

VMBO beveiliging

VMBO economie

VMBO administratie, handel en mode

VMBO consumptief en levensmiddelentechniek

VMBO verzorging

HAVO/VWO

MBO natuur en techniek

$\mathrm{MBO}$ landbouw en veeteelt

MBO milieu en groene ruimte

$\mathrm{MBO}$ laboratorium

MBO bouw

MBO grond-, weg- en waterbouw

MBO installatietechniek

MBO werktuigbouw en mechanische techniek

MBO motorvoertuigentechniek

MBO elektrotechniek

MBO grafische techniek

MBO procestechniek

MBO levensmiddelentechniek/vleesverwerking

MBO vervoer en logistiek

MBO automatisering

MBO openbare orde en veiligheid

$\mathrm{MBO}$ economie

MBO administratie

MBO handel

MBO secretariaat

MBO toerisme en recreatie

MBO bedrijfskunde

MBO dienstverlening en gezondheidszorg

MBO dokters-, tandarts- en dierenartsassistent

MBO apothekersassistent

$M B O$ verpleging

MBO sociaal-cultureel

$M B O$ verzorging

MBO uiterlijke verzorging

MBO horeca

MBO beweging en therapie

MBO geld, bank en belastingen

$M B O$ verzekeringswezen

$\mathrm{HO}$ natuur en techniek

HBO milieukunde en levensmiddelentechnologie

$\mathrm{HBO}$ laboratorium

HBO bouwkunde

HBO civiele techniek

HBO werktuigbouwkunde

HBO elektrotechniek

HBO informatica gemiddeld stijgend

erg hoog

gemiddeld

gemiddeld

gemiddeld

laag

hoog

hoog

erg laag

laag

gemiddeld

gemiddeld

hoog

gemiddeld

erg hoog

gemiddeld

laag

laag

gemiddeld

laag

laag

gemiddeld

laag

gemiddeld

gemiddeld

erg laag

erg hoog

laag

laag

gemiddeld

gemiddeld

gemiddeld

gemiddeld

gemiddeld

laag

gemiddeld

laag

gemiddeld

erg laag

laag

gemiddeld

hoog

gemiddeld

laag

gemiddeld

hoog

gemiddeld

gemiddeld

gemiddeld

laag

gemiddeld

hoog

laag

laag

laag

gemiddeld

stijgend stijgend

sterk dalend

constant

constant

constant

dalend

constant

sterk dalend

constant

constant

constant

sterk stijgend

sterk dalend

constant

constant

constant

sterk dalend

sterk stijgend

sterk stijgend

sterk dalend

sterk stijgend

sterk dalend

dalend

constant

constant

sterk dalend

dalend

constant

sterk stijgend

constant

constant

-

sterk stijgend

dalend

stijgend

sterk dalend

stijgend

sterk stijgend

stijgend

- 
Tabel 14.8 (vervolg)

Percentage werkenden dat deelneemt aan scholingstrajecten van 6 maanden of langer, gemiddelde 20012002

$\%$ typering

trend 2000-2002

HBO vervoer en logistiek

WO wiskunde en natuurwetenschappen

$\mathrm{HO}$ economie

HBO accountancy en bedrijfseconomie

HBO commerciële economie

HBO recht en bestuur

$\mathrm{HBO}$ secretariaat

HBO bedrijfskunde

WO econom(etr)ie

WO bedrijfskunde

WO accountancy en belastingen

WO rechten en bestuurskunde

$\mathrm{HO}$ onderwijs en sociaal-cultureel

HBO lerarenopleiding basisonderwijs

HBO lerarenopleiding talen

$\mathrm{HBO}$ lerarenopleiding natuur en techniek

HBO lerarenopleiding economie en maatschappij

HBO lerarenopleiding expressie

HBO tolk en vertaler

HBO communicatie en journalistiek

HBO maatschappelijk werk en hulpverlening

HBO personeel en arbeid

HBO uitvoerende en beeldende kunsten

WO letteren

WO sociale wetenschappen

$\mathrm{HO}$ medisch

HBO verpleegkunde

HBO (fysio)therapie

WO (dier)geneeskunde

10 gemiddeld

14 gemiddeld

Beroepen

Pedagogische beroepen

Leraar basisonderwijs

Docenten exacte, medische en verzorgende vakken (2e graads)

Docenten landbouw en techniek (2e graads)

Docenten talen en expressie

Docenten letteren (1e graads)

Onderwijskundigen en pedagogen

Culturele beroepen

Bibliotheekassistenten

Kunstenaars

Journalisten

Agrarische beroepen

Agrarische arbeiders

Technische, ambachts- en industrieberoepen

Productiemedewerkers

Conciërges

Bouwvakkers

Aannemers en installateurs

Architecten en bouwkundig projectleiders

Weg- en waterbouwkundigen

Weg- en waterbouwkundige arbeiders

Weg- en waterbouwkundige vakkrachten

Metaalarbeiders

Bankwerkers en lassers

Assembleurs

Monteurs

11 gemiddeld
8 laag

16 hoog

21 erg hoog

13 gemiddeld

21 erg hoog

12 gemiddeld

17 hoog

14 gemiddeld

13 gemiddeld

13 gemiddeld

13 gemiddeld

15 hoog

11 gemiddeld

10 gemiddeld

11 gemiddeld

15 hoog

32 erg hoog

15 hoog

13 gemiddeld

14 gemiddeld

12 gemiddeld

10 gemiddeld

12 gemiddeld

17 hoog

13 gemiddeld

16 hoog

27 erg hoog

sterk stijgend

constant

dalend

sterk dalend

-

sterk stijgend

sterk stijgend

sterk stijgend

constant

stijgend

sterk stijgend

sterk stijgend

sterk stijgend

sterk stijgend

sterk stijgend

-

dalend

sterk dalend

constant

constant

16 hoog

17 hoog

19 hoog

14 gemiddeld

16 hoog

16 hoog

11 gemiddeld

10 gemiddeld

10 gemiddeld

8 laag

7 laag

12 gemiddeld

13 gemiddeld

10 gemiddeld

9 laag

4 erg laag

10 gemiddeld

11 gemiddeld

10 gemiddeld

9 laag

7 laag

10 gemiddeld

6 dalend

6 erg laag dalend

20 hoog

11 gemiddeld sterk stijgend

sterk stijgend

sterk stijgend

sterk stijgend

constant

constant

sterk stijgend

constant

dalend

constant

sterk dalend

sterk dalend

dalend

sterk stijgend

sterk stijgend

sterk stijgend 
Tabel 14.8 (vervolg)

Percentage werkenden dat deelneemt aan scholingstrajecten van 6 maanden of langer, gemiddelde 20012002

\begin{tabular}{|c|c|c|c|}
\hline & $\%$ & typering & trend 2000-2002 \\
\hline Werktuigbouwkundig ontwerpers en hoofden technische dienst & 10 & gemiddeld & sterk stijgend \\
\hline Monteurs en controleurs elektrotechnische producten & 18 & hoog & sterk stijgend \\
\hline Elektromonteurs & 14 & gemiddeld & - \\
\hline Grafisch productiepersoneel & 4 & erg laag & - \\
\hline Grafische vakkrachten & 7 & laag & - \\
\hline Mechanisch operators & 11 & gemiddeld & sterk stijgend \\
\hline Procesoperators & 18 & hoog & sterk stijgend \\
\hline Confectie-arbeiders & 5 & erg laag & - \\
\hline Transportberoepen & 8 & laag & dalend \\
\hline Laders en lossers & 12 & gemiddeld & sterk dalend \\
\hline Chauffeurs & 5 & erg laag & - \\
\hline Vliegers, scheepskapiteins en leidinggevenden transport & 10 & gemiddeld & stijgend \\
\hline Medische en paramedische beroepen & 17 & hoog & constant \\
\hline Verpleeghulpen en leerling-verpleegkundigen & 52 & erg hoog & sterk stijgend \\
\hline Verplegenden en doktersassistenten & 12 & gemiddeld & dalend \\
\hline Therapeuten en verpleegkundigen & 13 & gemiddeld & sterk dalend \\
\hline Artsen & 26 & erg hoog & stijgend \\
\hline Apothekersassistenten en medisch laboranten & 13 & gemiddeld & - \\
\hline Medisch analisten & 9 & laag & - \\
\hline Economisch-administratieve beroepen & 13 & gemiddeld & constant \\
\hline Kantoorhulpen, inpakkers en colporteurs & 11 & gemiddeld & stijgend \\
\hline Bedrijfshoofden & 7 & laag & - \\
\hline Productieplanners & 10 & gemiddeld & sterk stijgend \\
\hline Organisatie-adviseurs & 13 & gemiddeld & - \\
\hline Organisatiedeskundigen & 11 & gemiddeld & sterk dalend \\
\hline Receptionisten en administratieve employés & 12 & gemiddeld & constant \\
\hline Boekhouders en secretaresses & 12 & gemiddeld & dalend \\
\hline Assistent accountants & 19 & hoog & constant \\
\hline Accountants & 26 & erg hoog & sterk stijgend \\
\hline Verzekeringsagenten & 10 & gemiddeld & - \\
\hline Commercieel employés & 12 & gemiddeld & constant \\
\hline Commercieel medewerkers & 14 & gemiddeld & sterk stijgend \\
\hline Juridisch en fiscaal medewerkers & 15 & hoog & sterk stijgend \\
\hline Juridisch, bestuurlijk medewerkers & 16 & hoog & sterk dalend \\
\hline Juristen & 17 & hoog & - \\
\hline Administratieve transportemployés & 8 & laag & constant \\
\hline Leidinggevenden & 11 & gemiddeld & - \\
\hline Managers & 9 & laag & - \\
\hline Medisch secretaresses & 9 & laag & sterk stijgend \\
\hline Informatica beroepen & 14 & gemiddeld & dalend \\
\hline Programmeurs & 17 & hoog & - \\
\hline Systeemanalisten & 13 & gemiddeld & - \\
\hline Informatici & 11 & gemiddeld & sterk dalend \\
\hline Sociaal-culturele beroepen & 15 & hoog & constant \\
\hline Activiteitenbegeleiders en medewerkers arbeidsbemiddeling & 20 & hoog & sterk stijgend \\
\hline Medewerkers sociaal-cultureel werk en personeel en arbeid & 13 & gemiddeld & - \\
\hline Sociaal-wetenschappelijk onderzoekers & 14 & gemiddeld & sterk dalend \\
\hline Verzorgende en dienstverlenende beroepen & 19 & hoog & stijgend \\
\hline Vakkenvullers & 49 & erg hoog & - \\
\hline Interieurverzorgers & 14 & gemiddeld & sterk stijgend \\
\hline Verkopers & 23 & erg hoog & constant \\
\hline Winkeliers & 14 & gemiddeld & - \\
\hline Hulpkrachten horeca en verzorging & 25 & erg hoog & sterk stijgend \\
\hline Ziekenverzorgenden & 11 & gemiddeld & stijgend \\
\hline Verzorgend personeel & 12 & gemiddeld & constant \\
\hline Bedrijfshoofden horeca & 11 & gemiddeld & sterk dalend \\
\hline Openbare orde- en veiligheidsberoepen & 18 & hoog & stijgend \\
\hline
\end{tabular}


Totaal alle sectoren

Tabel 14.8 (vervolg)

Percentage werkenden dat deelneemt aan scholingstrajecten van 6 maanden of langer, gemiddelde 2001 2002

$\% \quad$ typering trend $2000-2002$

Aspirant politieagenten, soldaten en beveiligingshulpkrachten

-

Politieagenten, onderofficieren en beveiligingsemployés

$\begin{array}{lll}24 & \text { erg hoog } & \text { sterk stijgend } \\ 13 & \text { gemiddeld } & \text { - }\end{array}$

Specifieke groepen werkenden

Vrouwen

Jongeren

Ouderen

Allochtonen

14 gemiddeld stijgend

29 erg hoog stijgend

18 erg laag

constant

Totaal

14 gemiddeld

sterk stijgend

Bron: ROA/CBS 